\title{
De ontwikkeling van medische expertise : een cognitief-psychologische benadering
}

Citation for published version (APA):

Boshuizen, H. (1989). De ontwikkeling van medische expertise : een cognitief-psychologische benadering. [Doctoral Thesis, Maastricht University]. Krips Repro. https://doi.org/10.26481/dis.19890224hb

Document status and date:

Published: 01/01/1989

DOI:

10.26481/dis.19890224hb

Document Version:

Publisher's PDF, also known as Version of record

\section{Please check the document version of this publication:}

- A submitted manuscript is the version of the article upon submission and before peer-review. There can be important differences between the submitted version and the official published version of record.

People interested in the research are advised to contact the author for the final version of the publication, or visit the DOI to the publisher's website.

- The final author version and the galley proof are versions of the publication after peer review.

- The final published version features the final layout of the paper including the volume, issue and page numbers.

Link to publication

\footnotetext{
General rights rights.

- You may freely distribute the URL identifying the publication in the public portal. please follow below link for the End User Agreement:

www.umlib.nl/taverne-license

Take down policy

If you believe that this document breaches copyright please contact us at:

repository@maastrichtuniversity.nl

providing details and we will investigate your claim.
}

Copyright and moral rights for the publications made accessible in the public portal are retained by the authors and/or other copyright owners and it is a condition of accessing publications that users recognise and abide by the legal requirements associated with these

- Users may download and print one copy of any publication from the public portal for the purpose of private study or research.

- You may not further distribute the material or use it for any profit-making activity or commercial gain

If the publication is distributed under the terms of Article $25 \mathrm{fa}$ of the Dutch Copyright Act, indicated by the "Taverne" license above, 


\section{DE ONTWIKKELING VAN MEDISCHE EXPERTISE}

\section{EEN COGNITIEF-PSYCHOLOGISCHE}

BENADERING 


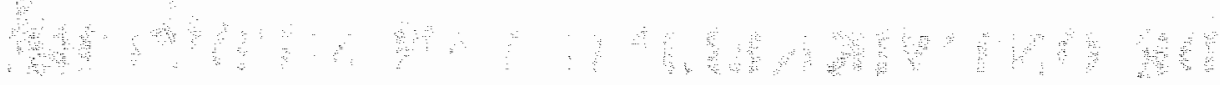

$$
\begin{aligned}
& \text { « क } \\
& \text { औ }
\end{aligned}
$$




\section{DE ONTWIKKELING VAN MEDISCHE EXPERTISE}

EEN COGNITIEF-PSYCHOLOGISCHE BENADERING

(ON THE DEVELOPMENT OF MEDICAL EXPERTISE;

A COGNITVE-PSYCHOLOGICAL APPROACH)

\section{PROEFSCHRIFT}

TER VERKRIUGING VAN DE GRAAD VAN DOCTOR AAN DE RIJKSUNIVERSITEIT LIMBURG TE MAASTRICHT, OP GEZAG VAN DE

RECTOR MAGNIFICUS, PROF. DR. F.I.M. BONKE, VOLGENS HET BESLUTT VAN HET COLLEGE VAN DEKANEN, IN HET OPENBAAR TE VERDEDIGEN OP VRIJDAG, 24 FEBRUARI 1989 OM 14.00 UUR

DOOR

HENNY PETRONELLA ADRIANA BOSHUIZEN GEBOREN TE WEESP

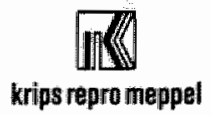


PROMOTORES:

prof. dr. H.G. Schmidt

prof. dr. J.J. Elshout

BEOORDELINGSCOMMISSIE:

prof. dr. H.F.M. Crombag (voorzitter)

prof. dr. J.A.P.J. Breuker

prof. dr. A.D. de Groot

prof. dr. H.J. van den Herik

prof. dr. H.A.M. Hulsmans

Het onderzoek dat in dit proefschrift wordt gepresenteerd, is mogelijk gemaakt door de SVO onder contractnummer \#6626 
Opgedragen aan

Hein, Rogier en Louise Claessen 
s.

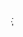

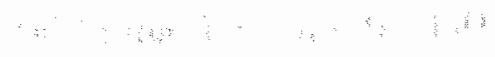




\section{INHOUDSOPGAVE}

IX VOORWOORD

XI SUMMARY

1 EXPERTISE EN PROBLEEMOPLOSSEN; DE ROL VAN KENNIS IN VERSCHILLENDE STADIA VAN HET LEERPROCES

Kenmerken van expertise. 1

De ontwikkeling van het expertisebegrip in de psychologie:

een historisch overzicht. 3

Intermezzo:

Informatievenwerking en inteme representatie van informatie. 9

Expertise in de geneeskunde:

een overzicht van onderzoek in dit domein

Een informatieverwerkingsmodel voor probleemoplossen in het medisch domein

Een schets van het in dit proefschrift te presenteren onderzoek. PROBLEEMREPRESENTATIE: RECALL STUDIES

Inleiding

Experiment 1

Algemene discussie 


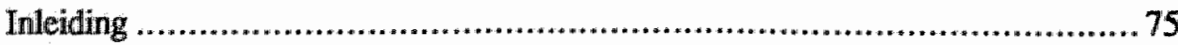

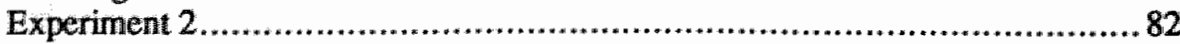

Algemene discussie .......................................................................... 99

\section{STRUKTURELE KENMERKEN VAN DE KENNIS}

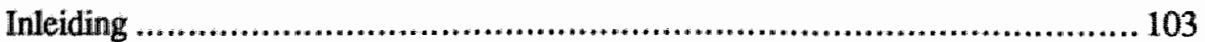

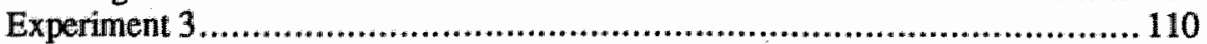

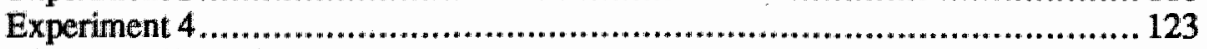

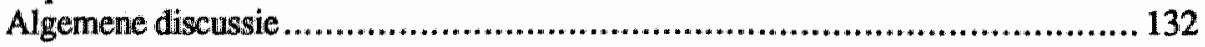

135 EEN ONTWIKKELINGSTHEORIE VAN MEDISCHE EXPERTISE

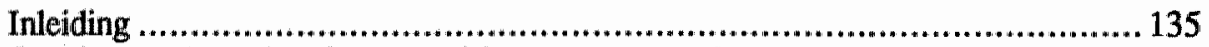

Stand van zaken: theorie en empirische ondersteuning ................................ 136

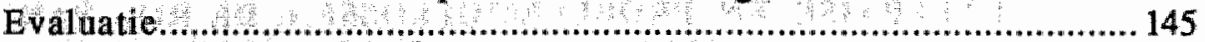

Implicaties voor het medisch onderwijs .............................................. 148

153 LITERATUUR

163 BIJLAGEN

Geïnstantieerde ziektescripts............................................................163

Teksten van de 4 casus in Experiment 1 ............................................... 165

Vier recallprotocollen

van de typische prostatitis casus ................................................. 175

Geanalyseerd hardop-denk protocol ....................................................... 179

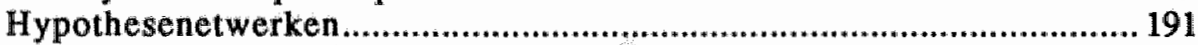

201 CURRICULUM VITAE 


\section{VOORWOORD}

Het onderzoeksprojekt, waarvan dit proefschrift het resultaat is, startte in 1979. Dit jaartal kan, achteraf gezien, beschouwd worden als een keerpunt in de geschiedenis van het onderzoek naar medisch probleemoplossen. De grote stroom van onderzoekingen naar de manier waarop artsen en studenten problemen oplossen, stagneerde toen en er was een duidelijke heroriëntatie op het onderzoeksveld nodig, voordat er weer resultaten geboekt konden worden. Dit proefschrift draagt de sporen van deze heroriëntatie. De studies die erin worden beschreven, hebben alle een theorie-vormend karakter. Gevieren resulteren ze in de theorie over de strukturele veranderingen die iemands medische kennis in de loop van diens ontwikkeling tot expert doormaakt. Deze theorie wordt in het laatste hoofdstuk geschetst.

Bij de totstandkoming van dit proefschrift ben ik aan velen dank verschuldigd.

- Aan degenen die in de loop van het onderzoeksprojekt meewerkten en meedachten: Hein Claessen, Pie Hobus en Metta Hofstra. Zij waren mijn sparringspartners. Samen deden we veel van het uitvoerend werk van het projekt.

- Aan onderzoekśassistenten, studentassistenten en stageaires Karin van Ee, Gerben Hupkes, Thom Lenz, Carien du Pon en Jolanda van de Water. $\mathrm{Zij}$ traden op als proefleider en scoorden grote hoeveelheden protocollen.

- Aan Karin van Ee en Bea Leliveld die de hardop-denk protocollen uittypten.

- Aan Hein Claessen en Pie Hobus die diverse versies van dilt proefschrift lazen. Hun commentaar was vaak prikkelend en steeds zeer doordacht.

- Aan Maureen Machiels-Bongaerts en Desiree Bronkers die de drukproeven corrigeerden.

- Aan Steve Foster die de Engels samenvatting becommentarieerde en corrigeerde.

- Aan leden van de vakgroepen onderwijsontwikkeling en onderwijsresearch, huisartsgeneeskunde, interne geneeskunde en cardiologie. $\mathrm{Zij}$ 
waren behulpzaam bij de ontwikkeling van de gebruikte casuîstiek en scoringsmodellen en traden op als proefpersoon.

- Zonder ook de medewerking van vele studenten geneeskunde en gezondheidswetenschappen die als proefpersoon aan de experimenten deelnamen, was dit proefschrift niet tot stand gekomen.

- Ook dank ik mijn promotoren Henk Schmidt en Jan Elshout. Veel van de ideeën in dit proefschrift heb ik van hen, vaak zonder dat ik me daar zelf bewust van was. Henk Schmidt zag als één van de eersten in, dat in dit onderzoeksterrein een verandering van perspektief nodig was alvorens er nieuwe vorderingen mogelijk zouden zijn. Hij heeft derhalve in belangrijke mate bijgedragen aan het welslagen van de onderzoekingen waarvan in dit proefschrift melding wordt gemaakt.

Ten slotte dient de financiële ondersteuning van het onderzoeksprojekt door SVO genoemd te worden. Zonder deze had dit proefschrift niet geschreven kunnen worden.

Valkenburg Lb, 1989

H.P.A. Boshuizen 


\section{SUMMARY}

Medical expertise is a subject of interest for clinical teachers. What makes a person an expert in this domain, and what is the best way to prepare students to become an expert? Naive opinions hold that medical expertise is associated with knowledge, experience, and good (that is quick, efficient and straight forward) problem solving. Until recently medical teachers and investigators in this domain believed that differences in problem-solving skills determined whether or not someone was an expert. However, both research into medical education and into human cognition have shown that this is no fruitful approach. Therefore the focus of attention has shifted toward differences in knowledge characteristics between persons of contrasting levels of expertise pertaining to differences in problem-solving. In this approach the concept 'internal representation" or 'problem representation' plays a pivotal role. Relevant problem information is selected and elaborated on, applying general or specific knowledge. The internal representation constitutes both selected and inferred information as well as activated knowledge.

The general research question of this dissertation 'What is medical expertise?' can be reformulated into two subquestions: 'What characterizes the knowledge of the medical expert as compared with novices and intermediates?' and 'How does the developmental process take place?'. In the first chapter these questions are further investigated and positioned in a historical context. In the same chapter the empirical methods that can be applied in this kind of research are described.

In Chapter 2 the first experiment is presented. In this study a free recall method was utilized to investigate the internal representation of a clinical case. Sixty-four subjects differing in level of expertise (second year, fourth year and fifth year students and family physicians) participated. This experiment showed that an increasing level of expertise is associated with better diagnostic performance. Furthermore, in the first stages of the development of expertise, the amount of represented case items increases, whereas in the later stages these items are better integrated and are represented in a more coherent way. The results suggest that the more experienced subjects select relevant information better, and finally it was shown 
that higher levels of expertise are associated with a faster representation rate.

In Chapter 3 this last result was taken as a starting point to investigate whether differences in knowledge structure underlie the observed differences in internal representation and diagnostic performance.

Both Anderson (1983) and Norman and Rumelhart (1978) suppose that expertise is attained by applying the learned concepts. Knowledge application causes a structural change: long search paths are shortened and general knowledge becomes specialized. This process is called 'compilation' (Anderson, 1983). Due to these structural changes, expert knowledge application is very quick and automatic when diagnosing a clinical case. Novices and intermediates, however, apply their knowledge actively, laboriously and consciously while reasoning about a case.

If this developmental process is indeed taking place, then a drastic restriction of the available reading time will have substantial consequences on the novices' and intermediates problem representation, whereas the experts' representation will scarcely suffer. In Experiment 2 this prediction was tested and confirmed by the data. One hundred and twenty subjects participated in this experiment: lay people, second, fourth and sixth year medical students and internists. The experts' internal representation was not affected by a strong restriction on the allowed reading time, while the novices and intermediates representation was seriously hampered. The same holds for the amount of knowledge that was activated. Regardless of the amount of time available (ample, sufficient or extremely short) experts activated the same small amount of knowledge, whereas novices and intermediates activated much more knowledge when they had ample or sufficient time. These subjects also activated much less knowledge when there was little time allowed. Content analysis of the applied knowledge provided further evidence for the assumption that the earlier stages of a learning process in a domain are characterized by the accumulation of knowledge with compilation following later.

Chapter 4 concerns the question of how medical expert knowledge is represented. The medical domain is characterized by a wide variety of diseases which can be presented to a doctor in many different ways and which may take many different courses. In order to account for the extreme adaptability of physician performance, the knowledge clusters that result from the compilation process must be enriched with knowledge concerning the patient characteristics that are associated with catching a disease, with the numerous ways a disease may manifest itself in a patient and with the incidence in different (sub)populations.

Feltovich and Barrows model (1984) of medical expert knowledge has these characteristics. Feltovich and Barrows hypothesize that physicians when diagnosing a patient try to activate and instantiate an illness script. Such an illness script describes the conditions in the patient and his or her medical, hereditary or social background that may have contributed to the patient's present disease (the Enabling Conditions), the disease process itself (the Fault), and the signs and symptoms that are caused by the 
disease and the course it may take (the Consequences). Research by Schmidt, Hobus, Patel and Boshuizen (1987) suggests that there are differences between experts and intermediates in the extent in which they rely on knowledge about Enabling Conditions in generating a plausible diagnosis. This finding supports the theory outlined above. Furthermore, Feltovich and Barrows assume that medical basic science knowledge plays an important role in the construction of the internal representation, especially when a finding in a patient deviates from what is normally found in patients with that disease.

Feltovich and Barrows' theory describes the representational format that might result from the compilation process that was hypothesized in Chapter 3 and from the enrichment and refinement of the knowledge with respect to multiple Enabling Conditions the Consequences of a Fault. There is however one element in Feltovich and Barrows' theory that diverges from the findings of the studies presented in the previous chapters. Their theory predicts that activation of an illness script causes the activation of the relevant basic science knowledge. However, Experiment 2 showed that medical experts apply far less basic science knowledge than intermediates and novices do.

In Chapter 4 two experiments are described that are designed to shed some light on these issues. Experiment 3 is a primarily explorative study with four subjects of differing levels of expertise ranging from a second year medical student to an experienced family physician. A think-aloud methodology was utilized. Its main objective was to see whether experts really apply knowledge that is richer in Enabling Conditions and more flexible in the Consequences of a disease. Both turned out to be the case. The other goal was to find out how subjects of different levels of expertise apply basic-science knowledge in representing and solving a clinical case. Contrary to the prediction that can be derived from Feltovich and Barrows' theory, it was found that in particular the less experienced subjects used basic-science knowledge

The finding that the expert in this experiment as compared with the students actually applied nearly no basic-science knowledge at all can be interpreted in three different ways:

- the expert's basic-science knowledge has become rudimentary, or

- the expert's basic-science knowledge still exists, but has become inert, or - the expert's basic-science knowledge has become compiled and is integrated into the illness-script knowledge that is applied while representing the case, hence leaving no traces in the think-aloud protocols.

Experiment 4 was designed to investigate these three hypotheses. Twenty subjects of four levels of expertise, again ranging from second year medical students to family physicians, participated. They were asked to diagnose a clinical case while thinking aloud. Afterwards they described the pathophysiological process that underlies the case findings. These two data sets were compared. The results of this last experiment indicate that experts' basic-science knowledge has not become inert or 
rudimentary but is compiled and integrated into the illness-script knowledge that is applied while thinking aloud.

Finally, in Chapter 5 the theoretical notions that are unfolded in the earlier chapters are discussed and brought together into a theory on the development of medical knowledge. These theoretical notions suppose that the development of medical expertise is characterized by several stages. In the first stage which roughly extends through the preclinical years of medical training, large amounts of knowledge are accumulated. Learning in this stage results in an elaborated knowledge base containing knowledge about the medical basic sciences and the clinical sciences. This type of knowledge is supposed to be represented in semantic networks and mental models. When the student enters the clinic and begins his or her clerkships, a new stage starts. This stage is characterized by knowledge compilation, enrichment and refinement. The knowledge resulting from these structural changes is conjectured to be dually represented: in illness scripts and in semantic nets and mental models. Both layers are presumed to be integrated, resulting in a knowledge base that allows for a flexible application of that knowledge.

The results of the experiments presented indicate that illness scripts do not originate solely from knowledge compilation and enrichment. Even the younger students seem to apply rudimentary illness scripts while diagnosing a case. The learning process rather seems to start at both knowledge layers at the same time, but with changing emphases. Finally in the expert stage, medical basic-science knowledge seems to be compiled and integrated into illness-script knowledge.

Further analyses showed that the theory lacks a representational format to represent to memory traces of the patients who were in the past diagnosed and treated by the student or the physician. Research by Norman et al. (1988) suggests that these memory traces are a powerful tool in diagnosing a new patient.

The model of medical expert knowledge that finally is presented in this chapter consists of three interrelated knowledge layers: knowledge about the medical basic sciences, represented in semantic networks and mental models; knowledge about diseases, the conditions enabling the acquisition of a disease and the associated signs and symptoms, represented in illness scripts; and the memories about former patients, represented in episodic memory traces.

A student who has the task to acquire such a complicated knowledge base runs the risk of overemphasizing one aspect at the cost of another. Especially in the clinical phase of medical education a student may concentrate on illness-script knowledge neglecting basic sciences, which may result in undesirable effects pertaining to the amount of basic-science knowledge and the integration of basic sciences into illness scripts. The chapter ends with several suggestions on how to prevent this learning style, derived from Collins et al. (in press) cognitive apprenticeship teaching model. 
HOOFDSTUK 1

\section{EXPERTISE EN PROBLEEMOPLOSSEN; DE ROL VAN KENNIS IN VERSCHILLENDE STADIA VAN HET LEERPROCES}

\section{KENMERKEN VAN EXPERTISE}

Het bezit van expertise wordt maatschappelijk hoog aangeslagen. Mensen verwachten van experts in een bepaald domein, dat ze in staat zijn om sneller en op een doeltreffender wijze een probleem uit hun vakgebied op te lossen dan anderen. Dit geldt voor allerlei terreinen van deskundigheid: van het ontwerpen en installeren van verwarmingssystemen tot het controleren van de jaarrekening van een middelgroot bedrijf, en van het plannen van de bouw van een nieuwe spoorbrug in een druk trajekt tot het behandelen van een patiënt met suikerziekte. Grote sommen geld worden door overheid en bedrijfsleven besteed aan scholing en vorming van experts, terwijl de verwerving van expertise veel inspanning en tijd vereist. Schattingen lopen uiteen van enige honderden tot vele duizenden uren, afhankelijk van het domein (Chi, Glaser en Rees, 1982). Als voorbeeld moge dienen het verwerven van expertise in de huisartsgeneeskunde: De opleiding van een huisarts kost de overheid ongeveer fl 140.000 (fl 20.000 per student per jaar, schattingen lopen uiteen van fl 14.000 tot $\mathrm{fl}$ 60.000 ). De huisarts in spe heeft dan al ongeveer 12.600 uur besteed aan zijn studie en aan het opdoen van praktische ervaring. Nog eens gemid- 
deld vijf jaar zijn nodig om een werkelijk ervaren huisarts te worden ${ }^{1}$, zodat er gemiddeld 21.800 uur nodig zijn om een expert in de huisartsgeneeskunde te vormen.

Mensen hebben vaak een intuittief oordeel over wat een deskundig arts, automonteur of advocaat is. Uit een enquête, afgenomen bij 35 personen, allen werkzaam bij de Rijksuniversiteit Limburg, bleek dat men een expert op een bepaald terrein beschouwt als iemand die over een grote begaafdheid, veel ervaring, grote kennis en domeinspecifieke vaardigheden beschikt. Daarnaast wordt hij of zij geacht veel meta-kennis te bezitten (dit is kennis over wat wel en wat niet bekend is in zijn vakgebied) en een echt overzicht over het vakgebied te hebben. Ten slotte bleek dat de respondenten de snelheid waarmee een beroepsbeoefenaar een probleem kan oplossen, de rechtlijnigheid en doelgerichtheid waarmee hij dat doet en de kwaliteit van de uitkomst of het produkt van belang achten bij de beoordeling of iemand al dan niet een expert is.

Begaafdheid, kennis en ervaring kunnen beschouwd worden als aspekten van expertise die een expert met zich meebrengt in een probleemsituatie. Ze vormen als het ware het sediment van zijn groei tot expert en zijn niet direkt waarneembaar. Hierdoor zijn ze niet eenvoudig te onderzoeken. Snelheid en kwaliteit van de uitkomst zijn dat wel. Het is dan ook niet verwonderlijk dat deze laatste aspekten van expertise vooral in wetenschappelijk onderzoek als afhankelijke variabele gebruikt zijn om verschillen tussen experts en novieten aan te tonen. De kwaliteit van het handelen van experts in het medisch domein is onder andere onderzocht door Elstein, Shulman en Sprafka (1978), Barrows, Feightner, Neufeld en Norman (1978), Hobus, Schmidt, Boshuizen en Patel (1987), Snoek (1989), en Friedman, Newsom en Entine (1978).

Ook de snelheid waarmee iemand tot een oplossing komt, blijkt samen te hangen met diens expertiseniveau. Sternberg (1977), Boshuizen en Claessen (1981), Beck, Perfetti en McKeown (1982) en G.R. Norman, Muzzin en Rosenthal (1985) laten zien dat experts minder tijd nodig hebben om met een oplossing te komen dan beginnelingen. Een voorbeeld is het diagnosticeren van huidaandoeningen dat door Norman, Muzzin en Rosenthal (1985) werd onderzocht bij personen van verschillend expertiseniveau.

Het probleemoplossingsproces verloopt bij experts op een ordelijkere wijze. Jansweijer, Elshout en Wielinga (1985) vonden dat de aanpak van een beginneling gekenmerkt wordt door een zeer korte oriëntatie op het probleem, door impasses en door onderbrekingen van het probleemoplossingsproces waarin tussenuitkomsten worden gecontroleerd. Experts daarentegen plegen zich vooraf uitgebreid te oriënteren en cok meer tijd te

\footnotetext{
IDit is uiteraard een ruwe schatting die gebaseerd is op het onderzoek van Hofstra, Hobus, Boshuizen en Schmidt (1988). De Faculteit der Geneeskunde hanteert een norm van 5 jaar parktijkervaring bij de selektie van huisartsen die aspirant-huisartsen willen begeleidlen.
} 
besteden aan een evaluatie van het eindresultaat (Elshout, 1983, Jans. weijer et al., 1985; Brown 1978, Gítomer en Glaser, in druk; Voss, Tyler en Yengo, 1983).

Een minder voor de hand liggend kenmerk van experts - dat dan ook door de ondervraagde leken niet werd genoemd - is hun vermogen om informatie te onthouden die aan een bepaalde taak is gerelateerd. In meerdere studies in het medisch domein (Claessen en Boshuizen, 1985; Norman, Jacoby, Feightner en Campbell, 1979; Patel en Frederiksen, 1984) is vastgesteld dat er een relatie is tussen de hoeveelheid 'free recall' en expertise. Schmidt, Hobus, Patel en Boshuizen (1987) confronteerden ervaren huisartsen en net afgestudeerde basisartsen met 32 korte casusbeschrijvingen, waarbij de vraag aan de proefpersonen was te vertellen welke diagnose hen het meest plausibel leek. Nadat de helft van de casus op deze manier aan de orde was geweest, werd de proefpersonen gevraagd welke informatie ze zich nog van de verschillende casus konden herinneren. Hierbij werden twee retrieval cues gebruikt: de klacht van de patiënt in de casus en de diagnose die de proefpersoon daarbij had geuit. Deze zogenaamde 'free recall' lijkt een andere belangrijke uitingsvorm van expertise te zijn.

Wanneer we in dit proefschrift spreken van 'expertise' dan doelen we vooral op de interne factoren: de kennis en ervaring die iemand in de loop van zekere tijd heeft opgedaan. Door deze kennis en ervaring is de expert in staat de prestaties te leveren die hiervoor zijn besproken. Kennis en ervaring laten we hier nog ongedefinieerd, ze worden in een aantal volgende paragrafen nader uitgewerkt.

\section{DE ONTWIKKELING VAN HET EXPERTISEBEGRIP IN DE PSYCHOLOGIE: EEN HISTORISCH OVERZICHT}

Het onderzoek naar expertise en naar de rol die kennis en ervaring daarin spelen, neemt tegenwoordig een belangrijke plaats in in de cognitieve psychologie. Dit is niet altijd zo geweest. Het woord 'expertise' zal men bijvoorbeeld in de geschriften van de psychologen uit de eerste helft van deze eeuw niet tegenkomen. Begrippen als 'denken' en 'probleemoplossen' vinden we echter wel. Probleemoplossen en, wat wel genoemd werd, het 'produktieve denken' waren onderwerp van studie van de psychologen van de Würzbürger Schule zoals Külpe, Seltz, K.Bühler en Ach. Ook Gestaltpsychologen als Köhler, Wertheimer, Maier en Duncker deden daarnaar onderzoek. Hierbij moet wel worden aangetekend dat men in de eerste helft van de 20 -ste eeuw van mening was dat hogere cognitieve processen, waarvan denken er één is, ontoegankelijk zijn voor experimenteel onderzoek. Deze opvatting werd krachtig verdedigd door Wundt (1918).

Behalve methodologische overwegingen verboden ook overwegingen van theoretische aard om onderzoek naar "hogere" denkprocessen te doen. 
In de toenmalige opvatting over het menselijke cognitieve systeem werd een strikt onderscheid gemaakt tussen waarneming, denken, geheugen, kennis en probleemoplossen. Deze notie leidde tot een aanpak waarbij geprobeerd werd deze verschillende faculteiten van het menselijk cognitief funktioneren zo zuiver mogelijk, dat wil zeggen geisoleerd van andere funkties, te onderzoeken. En als er al onderzoek werd gedaan naar de invloed van ervaring en kennis op het oplossen van problemen, dan gebeurde dit vanuit de veronderstelling dat deze factoren iemand blind kunnen maken voor eenvoudige oplossingen die de naiteve probleemoplosser wel ziet.

Een voorbeeld hiervan is het onderzoek van Luchins (1942). Deze legde zijn proefpersonen taken voor waarbij de opdracht was een bepaalde hoeveelheid water af te meten met behulp van drie vaten van verschillende inhoud, die onbeperkt gevuld en geleegd konden worden. Gegeven zijn bijvoorbeeld een vat met een inhoud van 21 Eenheden, eén met een inhoud van 127 Eenheden en één van drie Eenheden. Opdracht was 100 Eenheden af te meten. Luchins legde de proefpersonen vijf van deze opgaven voor, die steeds op dezelfde manier konden worden opgelost, namelijk door het grote vat te vullen en er én maal de inhoud van het kleinere vat uit te scheppen en twee keer de inhoud van het kleinste vat. $\mathrm{Na}$ deze vijf opgaven volgden er nog vijf. Hiervan konden er twee op dezelfde manier worden opgelost als de vijf voorafgaande, maar ze konden ook op een eenvoudigere wijze worden opgelost. Eén opgave kon niet op deze 'standaard'wijze worden opgelost. De resultaten van Luchins lieten zien, dat de meeste proefpersonen persisteerden in de aanpak die ze in de eerste vijf opgaven hadden geleerd. Hierdoor gingen ze bij deze latere opgaven op een inefficiënte wijze te werk en lukte het ze vaak niet om de opgave die niet op deze manier kon worden opgelost, tot een goed einde te brengen. Luchins vergeleek hun prestaties met de prestaties van een andere groep proefpersonen die niet de eerste vijf opgaven hadden gedaan. Deze proefpersonen kwamen tot beduidend betere en efficiëntere prestaties. Dit effekt van de ervaring noemde Luchins het "Einstellungseffekt. De ervaring die de proefpersonen hadden opgedaan, leidde dus tot een inefficiënte oplossing.

Maier (1930, 1931) en Birch en Rabinovich (1951) onderzochten de hypothese dat het hebben van voorkennis, vooral wanneer die voorkennis kort daarvoor is geaktiveerd, een belemmerende werking kan hebben op het oplossen van problemen. In Maiers onderzoek (Maier 1930, 1931) werd een proefpersoon in een kamer gebracht waarin twee touwen aan het plafond hingen. Verder lagen er verspreid in die kamer diverse voorwerpen. Opdracht aan de proefpersoon was de touwen aan elkaar te knopen, maar de afstand tussen de touwen was zo groot dat de proefpersoon fysiek niet in staat kon zijn beide touwen tegelijk vast te pakken. Maier onderzocht in deze situatie welke methoden de proefpersonen gebruikten om dit probleem op te lossen. Eén van die methoden bestond enuit eén van de voorwerpen die in de kamer lagen als hulpmiddel te gebruiken. 
Deze methode lag blijkbaar niet zo voor de hand, getuige het feit dat Maier vaak duidelijke hints in die richting moest geven, anders kwam men niet op dat idee. In principe zijn vele voorwerpen als hulpmiddel te gebruiken. Een nijptang kan bijvoorbeeld gebruikt worden om een touw te verzwaren, waardoor het gemakkelijker zwaait. Je moet deze alleen wel in die funktie 'voor je kunnen zien' en dus abstraheren van de normale funktie van dat voorwerp. En dat gebeurt blijkbaar niet zo maar vanzelf. In een vervolgonderzoek door Birch en Rabinovich (1951) bleek dat dit abstraheren van de normale funktie ook nog eens bemoeilijkt wordt wanneer de proefpersoon in een taak, voorafgaand aan het touwexperiment dat voorwerp in zijn echte funktie heeft gebruikt; bijvoorbeeld spijkers met de nijptang hebben uitgetrokken. Dit verschijnsel, dat iemand een voorwerp niet los kan zien van de normale funktie en het daardoor niet op een minder conventionele manier kan gebruiken, noemde men funktionele fixatie'.

Minder aandacht had men in die tijd voor de vraag welke kenmerken van de proefpersonen een belangrijke rol spelen bij het oplossen van problemen. Kennis en ervaring als mogelijke determinanten werden, zoals we hebben gezien, vooral als negatieve faktoren beschouwd. Ook voor de vraag hoe het probleemoplossingsproces zich voltrekt, hadden de onderzoekers in die tijd weinig belangstelling. In tegendeel, men was vooral geimponeerd door het verschijnsel dat de oplossing van de problemen zich vaak als een plotseling optredend inzicht, zonder een duidelijke redenering aan de probleemoplosser voordoet zoals dat bijvoorbeeld bij de apen van Köhler (1925) het geval was. En ook het verschijnsel van 'incubatie' trok de aandacht. Dit verschijnsel kan optreden als iemand bij eerste kennisname van een probleem niet weet hoe het opgelost kan worden. Het gebeurt dan wel dat later, na een periode waarin in het geheel niet aan het probleem is gedacht, de oplossing zich plotseling, zonder een duidelijke aanleiding, aan de probleemoplosser voordoet.

Theorie en de empirische ondersteuning daarvoor leidden de generatie van experimenteel psychologen, die aktief was in de eerste helft van deze eeuw dus tot de conclusie dat de relatie tussen kennis en ervaring enerzijds en probleemoplossen anderzijds slechts een zeer twijfelachtige is. Kennis en ervaring kunnen het zicht op de oplossing van een probleem verhinderen of op zijn minst bemoeilijken. Hun resultaten suggereren dat inderdaad. Het duurde dan ook een hele tijd voordat de tegenovergestelde positie werd ingenomen.

Na deze aktiviteiten in de eerste helft van deze eeuw is het onderwerp 'probleemoplossen' geruime tijd uit de aandacht verdwenen. De belangstelling in de psychologie was verschoven naar intelligentie, leren en waarneming. Het onderzoek dat werd gedaan, werd in sterke mate beïnvloed door de behavioristische opvatting dat de psychologie zich slechts met uiterlijk waarneembaar gedrag mag bezig houden. Een uitzondering vormt het Psychologisch Laboratorium van de Universiteit van Amsterdam waar Otto Selz van de Würzbürger Schule in de jaren ' 30 werkzaam 
was. Zijn leerling De Groot deed daar onderzoek naar het denken van schakers. De Groot was wel geïnteresseerd in denkprocessen. Hij veronderstelde dat grootmeesters, de schaakexperts bij uitstek, bij het schaakspel beter presteren doordat zij meer zetten overwegen en deze verder doorredeneren dan niet-experts. Om deze hypothese te onderzoeken zette hij grootmeesters, meesters en plaatselijke kampioenen stellingen voor uit onbekende toernoøipartijen en hij vroeg zijn proefpersonen welke zet zij zouden doen als zij in deze partij nu met wit aan zet zouden zijn. Daarbij vroeg hij ze hardop te denken. De Groot concludeerde dat zijn hypothese niet opging. Het verschil tussen de grootmeesters en de andere schakers kwam niet tot uitdrukking in kenmerken van het denkproces maar in de kwaliteit van de zetten die door de experts werden overwogen. Grootmeesters dachten na over betere zetten, die vaker tot een goede voortzetting van de partij leidden dan de zetten die door minder goede schakers werden overwogen.

De Groot liet zijn proefpersonen echter ook andere taken uitvoeren. Hij onderzocht onder andere hoe goed meer en minder ervaren schakers in staat waren tot reproduktie van 14 schaakstellingen die afkomstig waren uit (groot)meesterpartijen, waarbij gemiddeld 17 stukken op het bord stonden. Vier proefpersonen, een grootmeester, een meester, een hoofdklassespeler en een onderbondspeler, deden aan dit onderzoek mee. $\mathrm{Zij}$ bestudeerden de stellingen steeds enige seconden, waarna ze deze reproduceerden. De grootmeester en de meester waren in staat om de stellingen vrijwel perfekt te reproduceren, terwijl de andere proefpersonen niet verder kwamen dan enkele stukken.

Deze twee resultaten samen leidden tot de conclusie, dat schaakgrootmeesterschap in de eerste plaats bestaat uit een uitermate gedifferentieerd bestand van ervaringskennis dat gebaseerd is op een grote hoeveelheid eerder gespeelde en geanalyseerde partijen. Dit bestand aan ervaringskennis kan volgens De Groot beschouwd worden als een mentaal schaakprogramma met uitzonderlijke reikwijdte en kwaliteit. Dit stelt de grootmeester in staat om een schaakpositie bijna onmiddellijk te herkennen als éen die behoort tot een bepaald type. Uit de plaats van de stukken kan hij ongeveer 'zien' wat voor afruil er heeft plaats gevonden. Hij ziet meteen wie er beter voor staat en hoe de partij voortgezet kan worden. Dankzij die opgebouwde ervaringskennis kan het denkproces van de grootmeester op een heel ander niveau starten (De Groot, 1981). Deze ervaringskennis wordt ook ingezet bij het waarnemen en onthouden van schaakstellingen die slechts korte tijd getoond worden. Vervolgonderzoek door Jongman (1968) en Chase en Simon (1973a, 1973b) ondersteunt dit resultaat. Het voordeel van de experts verdween bijvoorbeeld wanneer ze werden geconfronteerd met een stelling die op volstrekt willekeurige wijze tot stand was gekomen en waarbij ze geen gebruik konden maken van hun eerdere ervaringen.

De Groot was in zijn belangstelling voor expertise en voor het aandeel van ervaringskennis daarin lange tijd een eenling. Ook toen in de ja- 
ren '60 een hernieuwde belangstelling ontstond voor probleemoplossen bleef de strikte scheiding tussen kennis enerzijds en probleemoplossen anderzijds lange tijd standhouden. Dit blijkt bijvoorbeeld uit de definitie van 'probleem' die Frijda en Elshout (1976) geven in hun overzichtsartikel over de belangrijkste theorieën en experimenten die deze periode kenmerken. In die definitie moet een experimentele taak aan twee criteria voldoen, wil er sprake zijn van een probleem: a) de oplosser mag er niet zo maar een oplossing voor weten en b) hij mag niet over een strategie beschikken die automatisch tot de oplossing voert.

De opkomst van de hernieuwde belangstelling voor probleemoplossen wordt gemarkeerd door Newell en Simon's (1956) artikel over de Logic Theorist. Deze Logic Theorist is een computerprogramma dat het denken van een logicus simuleert. Het programma beschikt daartoe over de noodzakelijke logische basiskennis en over een aantal algemeen toepasbare probleemoplossingsheuristieken ${ }^{2}$. Met behulp van deze heuristieken is het in staat zelfstandig nieuwe logische stellingen te produceren. Dit simulatieprogramma heeft een aantal kenmerken die illustratief zijn voor de toen heersende theoretische opvattingen. Ten eerste zijn in dit simulatieprogramma kennis en probleemoplossingsstrategieën volledig onafhankelijke componenten. Verder zijn de probleemoplossingsstrategieën die erin worden gebruikt heuristisch van aard. Deze voeren dus, per definitie, niet automatisch tot een oplossing. Tenslotte zijn de gebruikte heuristieken zeer algemeen, in die zin dat ze bij logische problemen net zo goed toepasbaar zijn als bij allerlei andere problemen. In hun boek $\mathrm{Hu}$ man Problem Solving (Newell en Simon, 1972) gebruiken Newell en Simon dezelfde heuristieken om de oplossing van zeer uiteenlopende probleemtypen te simuleren.

Newell en Simon (1972) beschouwen probleemoplossen als het doorzoeken van een probleemruimte waarbij men stapsgewijs van het probleem naar de oplossing gaat. Deze oplossingsstappen worden uitgevoerd met behulp van de operatoren die in het kennisbestand liggen opgeslagen. Bij grote probleemruimten is het onmogelijk deze uitputtend te doorzoeken, de probleemoplosser moet wel gebruik maken van heuristieken, als er tenminste geen hanteerbare algoritmen bestaan die gegarandeerd tot de oplossing voeren. Inventariseren en analyseren van de gebruikte heuristieken vormden de hoofdmoot van hun onderzoek. Aan kenmerken van de inhoudelijke kennis die de probleemoplosser daarbij gebruikt, werd weinig aandacht besteed.

De benadering van Newell en Simon rust op twee pijlers. Aan de ene kant is er het onderzoek van de manier waarop mensen problemen oplossen. Zij gebruikten daartoe een hardop-denk methode. Aan de andere kant is er de computersimulatie van het menselijke probleemoplos-

${ }^{2}$ Newell en Simon onderscheiden verschillende methoden om problemen op te lossen. Aan de ene kant zijn er de algoritmen die gegarandeerd tot een oplossing leiden. Aan de andere kant zijn er de heuristíeken. Dit zijn methoden die niet gegarandeerd tot een oplossing leiden, maar waarvan de ervaring heeft geleerd dat ze dit vaak wel doen. 
singsproces. Door deze twee methoden te gebruiken en de uitkomsten met elkaar te vergelijken waren de onderzoekers in staat de resultaten die voortkwamen wit de ene methode te valideren aan de resultaten van de andere methode ${ }^{3}$. Hun redenering was daarbij als volgt. Als het mogelijk zou blijken een denkproces na te bootsen en als dit nagebootste proces dezelfde kenmerken zou vertonen als het denkproces dat gesimuleerd wordt (als het programma bijvoorbeeld dezelfde fouten maakt), was hiermee aangetoond dat het programma een 'ware afbeelding' was van het denkproces dat zich in werkelijkheid tijdens het oplossen van het probleem had afgespeeld.

Alle simulaties waren gebaseerd op hetzelfde grondprincipe. Op deze manier werd dus extra bewijs verkregen voor de juistheid van hun algemene theorie over probleemoplossen.

Het accent op algemene redeneerprocessen, die in uiteenlopende taken kunnen worden toegepast, is de laatste jaren verdwenen. En ook de strikte scheiding tussen kennis en probleemoplossen is vervaagd. Dit is het resultaat van het baanbrekende inzicht, dat zelfs bij het tot een goed einde brengen van een eenvoudige taak als die van Luchins (1942) een enorme hoeveelheid relevante kennis wordt ingezet. De steeds toenemende geheugencapaciteit en snelheid van de gebruikte computers, waardoor ook probleemoplossen in semantisch rijkere domeinen kon worden gesimuleerd, heeft daarbij zeker ook een rol gespeeld. Met semantisch rijke domeinen worden die domeinen bedoeld waarin veel kennis nodig is om een probleem op te kunnen lossen. In de afgelopen tien jaar is daardoor steeds meer onderzoek gedaan naar het oplossen van problemen in de meest uiteenlopende terreinen: thermodynamica (Bhaskar en Simon, 1977; Jansweijer, Elshout en Wielinga, 1985), mechanica (Chi, Feltovich en Glaser, 1981), accountancy (Bouwman, 1980), geneeskunde (Elstein, Shulman en Sprafka, 1978; Lesgold, Feltovich, Glaser en Wang, 1981) en zelfs naar iets dat op het eerste gezicht zo eenvoudig is, namelijk boodschappen doen (Lave, Murtaugh en De la Roche, 1984).

Samenvattend kunnen we zeggen, dat theorieën over en onderzoek naar probleemoplossen inmiddels heel andere kenmerken hebben gekregen. De strikte scheiding tussen de toepassing van kennis en het gebruiken van probleemoplossingsstrategieën is verdwenen. Het accent is ver-

${ }^{3}$ Beide methoden dienden ook gevalideerd te worden. De simulatiemethode was nieuw, dus er waren geen gegevens bekend over de mogelijkheden en onmogelijkheden ervan. De hardop-denk methode werd, evenals de introspektie- en de retrospektiemethode, door vorige generaties van onderzoekers als niet-valide beschouwd. In de onderzoekingen van Maier $(1930,1931)$ bleek bijvoorbeeld dat proefpersonen vaak niet doorhadden dat de proefleider ze een hint had gegeven. Uit de resultaten van het onderzoek bleck zonneklaar dat hun gedrag wel door deze hints werd beïnvloed. In de retrospektieve verslagen werden deze hints echter niet als oorzaak voor dat gedrag gegeven. De retrospekties vormden dus geen valide weergave van het proces dat zich had afgespeeld. Eerder waren het dubieuze reconstructies. 
schoven van algemeen toepasbare strategieèn naar domein-specifieke kennis en oplossingsmethoden. De stringente definitie dat een probleem slechts een probleem is als iemand er niet meteen een oplossing voor weet, is daarbij losgelaten. Eigenlijk wordt probleem tegenwoordig gebruikt in de betekenis van niet triviale taak. Daarmee is probleemoplossen equivalent geworden met het toepassen van kennis en is het leren oplossen van problemen geherdefinieerd als de ontwikkeling van expertise in een bepaald domein.

\section{INTERMEZZO: INFORMATIEVERWERKING EN INTERNE REPRESENTATIE VAN INFORMATIE}

In deze en de volgende paragrafen zullen we de onderzoekingen bespreken die meer inzicht verschaffen in de relatie tussen expertise, probleemoplossen en de rol van kennis daarbij. Alvorens we daar echter op ingaan, zullen we in dit intermezzo stilstaan bij de manier waarop in de hedendaagse psychologie wordt aangekeken tegen de rol van kennis bij cognitieve processen van zeer uiteenlopende aard ${ }^{4}$. Daarna zullen we ons richten op de vraag hoe de ontwikkeling van expertise in dit model te plaatsen is, waama we tenslotte in zullen gaan op een aantal methoden om de effekten van expertise te meten.

In de hedendaagse psychologie die zich bezighoudt met cognitieve processen staan twee begrippen centraal. Aan de ene kant is dat de verwerking van informatie die ons via de zintuigen bereikt en aan de andere kant is dat het geven van betekenis aan die informatie. Deze begrippen zijn toepasbaar op cognitieve processen van zeer uiteenlopende aard: waarneming (Neisser, 1976), geheugen (Shiffrin, 1975) en probleemoplossen (Mayer, 1983).

Globaal genomen gaat men ervan uit dat binnenkomende informatie, zoals auditieve en visuele stimuli, eerst wordt opgevangen in een sensorische buffer. Deze stimuli kunnen afkomstig zijn van allerlei bronnen in onze omgeving zoals de weg waarop we rijden, de buurman die iets roept of een blad papier waarop een probleem staat beschreven. Na een eerste bewerking in deze sensorische buffer gaat de informatie vervolgens door naar het korte duur geheugen ${ }^{5}$. Hier vindt verdere verwerking van de in-

\footnotetext{
${ }^{4}$ Dat aan cognitieve processen van zeer verscheiden aard éen en hetzelfde mechanisme ten grondslag ligt, wil uiteraard niet zeggen dat deze processen niet van elkaar onderscheidbaar zijn. Probleemoplossen en waarneming bijwoorbeeld zijn uiteraard zeer verschillende processen. Ze hebben alleen een belangrijk aantal kenmerken gemeenschappelijk, die terug zijn te voeren op een aantal kenmerken van het cognitieve systeem. ${ }^{5}$ Splitsing in een korte duur geheugen en cen lange duur geheugen wil niet zeggen dat verondersteld wordt dat er twee fysisch te onderscheiden systemen in de hersenen aanwezig zijn. Veel auteurs nemen aan dat het korte duur geheugen bestaat uit dat deel van
} 
formatie plaats met behulp van kennis die opgeslagen is in het lange duur geheugen en die geaktiveerd wordt door de binnenkomende informatie. In dit laatste deel van het proces wordt dus betekenis aan de informatie gegeven. Het gehele proces vanaf de bewerking door de zintuigen tot en met de betekenisgeving wordt aangeduid met de term "informatieverwerking!.

Deze verdere verwerking in het korte duur geheugen kan bestaan uit elaboratie op de input. In dit proces wordt de binnenkomende informatie aangevuld met behulp van bestaande kennis. Als we bijvoorbeeld een verslag lezen over een treinreis van Amsterdam naar Praag, dan weten we, ook zonder dat het wordt vermeld, dat de betrokkene daartoe een kaartje heeft gekocht, dat er sprake is van een conducteur en van medereizigers in de trein en dat de reiziger vermoedelijk bagage bij zich heeft. Dit elaboratieproces vindt automatisch plaats en stuurt de mate van verwerking die binnenkomende informatie ondergaat. Er is weinig verwerking van die informatie nodig als de informatie perfekt aansluit bij de aanwezige kennis. Is er sprake van een discrepantie of van een onverwachte wending, dan is een preciezere verwerking noodzakelijk. In ons reisvoorbeeld kunnen passages over een kaartje zeer snel worden doorgenomen, tenzij zou blijken dat de reiziger er geen gekocht heeft.

Een ander proces dat plaatsvindt; is een selektieproces. Door de kennis die we over een bepaald onderwerp hebben, kunnen we bijvoorbeeld hoofdzaken van bijzaken onderscheiden en onze aandacht op de hoofdzaken richten. Hierdoor wordt sommige informatie dieper verwerkt dan andere, terwijl nog andere delen van de input vrijwel worden overgeslagen.

De binnenkomende informatie vormt - tezamen met de produkten van de bewerkingen - de inhoud van het korte duur geheugen. Dit innerlijk beeld van de informatie wordt de interne representatie genoemd. Door de elementen van deze interne representatie kan weer andere kennis worden geaktiveerd, waardoor een volgende cyclus van bewerkingen kan plaatsvinden. De interne representatie is dus een dynamisch geheel dat in de tijd verandert tengevolge van continue verwerking van de informatie. De vorm die de interne representatie uiteindelijk aanneemt, wordt door meerdere factoren bepaald. Aan de ene kant is er de informatie zelf die moeilijk of gemakkelijk, samenhangend of niet samenhangend, redundant of niet redundant kan zijn. Deze kenmerken van de informatie bepalen of iets snel en gemakkelijk gerepresenteerd kan worden en of relevante kennis erdoor wordt geaktiveerd. Aan de andere kant zijn er de kenmerken van de kennis zelf die bepalen of deze door de binnenkomende informatie snel geaktiveerd zal worden.

het lange duur geheugen dat geaktiveerd is. Mocht dit zo zijn, dan is met even veel recht aan te nemen dat informatie eerst in het lange duur geheugen komt en pas daarna in het korte duur geheugen, zoals Shiffrin (1975) veronderstelt. 
Verschillen in interne representatie, die samenhangen met kenmerken van de informatie waardoor relevante voorkennis al dan niet wordt geaktiveerd, zijn onder andere onderzocht door Dooling en Lachman (1971) en Bransford en Johnson (1972). Bransford en Johnson (1972) lieten hun proefpersonen een tekst lezen die opgebouwd was uit zinnen die op zich niet moeilijk te representeren waren. Ze bevatten bijvoorbeeld geen moeilijke termen of zinsconstructies. Toch is het voor de lezer niet eenvoudig een coherente interne representatie van de hele tekst te vormen. Het is moeilijk om te begrijpen waarover deze tekst eigenlijk gaat.

A newspaper is better than a magazine. A seashore is a better place than the street. At first, it is better to run than to walk. You may have to try several times. It takes some skill but it's easy to learn. Even young children can enjoy it. Once successful, complications are minimal. Birds seldom get too close. Rain however, soaks in very fast. Too many people doing the same thing can also cause problems. One needs lots of room. If there are no complications, it can be very peaceful. A rock will serve as an anchor. If things break loose from it, however you will not get a second chance.

(Bransford en Johnson, 1972)

Bransford en Johnson lieten sommigen van hun proefpersonen deze tekst zonder titel lezen, terwijl anderen het verhaaltje met titel kregen voorgelegd: "Making and flying a kite". Daarna vroegen ze hun proefpersonen de tekst te reproduceren en aan te geven hoe begrijpelijk ze de informatie vonden. De resultaten laten zien, dat aanwezigheid van een interpretatiekader voor de binnenkomende informatie ertoe leidt dat men de tekst begrijpelijker vindt en beter onthoudt. Oftewel, ten gevolge van de aktivatie van toepasselijke kennis is er sprake van een meer coherente en verrijkte interne representatie van de informatie, hetgeen leidt tot een betere recall. Vertaald in termen van het informatieverwerkingsmodel: de tekst zonder titel aktiveert onvoldoende kennis om met behulp van elaboratieprocessen op een samenhangende wijze te worden gerepresenteerd.

Ook de kenmerken van de kennis die entoe leiden dat de betreffende kennis al dan niet gemakkelijk door binnenkomende informatie wordt geaktiveerd, zijn onderzocht. Een belangrijk kenmerk blijkt daarbij te bestaan uit de context waarin de kennis is opgedaan. Dit kan de fysieke context zijn, zoals door Godden en Baddeley (1975) werd aangetoond of de emotionele context zoals Bower, Monteiro en Milligan (1978) lieten zien. Een gelijke context bij leren en evocatie van het geleerde bleek tot een betere aktivatie van die kennis te leiden dan verschillende contexten.

De context speelt ook een belangrijke rol in het onderzoek naar aktivatie van kennis bij probleemoplossen. Chi, Glaser en Rees (1982) lieten bijvoorbeeld zien dat kennis alleen dan gemakkelijk wordt geaktiveerd wanneer deze gekoppeld is aan de condities waaronder deze mag worden toegepast. Leinhart (1987) onderscheidt 'Situated knowledge' en 'Con'text-free Principled Knowledge'. Situated knowledge is kennis die geldig is en toepasbaar is binnen een specifieke situatie en in hoge mate is toe- 
gesneden op die situatie. Een ander kenmerk van deze kennis is dat hij in hoge mate geproceduraliseerd 6 is. Dat wil zeggen dat de kennis de vorm heeft van een procedure die kan worden toegepast indien aan bepaalde voorwaarden is voldaan. Contextvrije kennis is algemeen geldige kennis. Leinhart laat zien dat als in een situatie zowel situated knowledge als context-free knowledge toepasbaar zijn, de algemene kennis als het ware overstemd wordt door de situatiegebonden kennis. Volgens J.R. Anderson (1982) komt dit voort uit het feit dat algemeen geldige kennis niet automatisch door de situatie wordt geaktiveerd, maar dat het gebruik ervan altijd door tussenkomst van algemene probleemoplossingsheuristieken moet plaatsvinden. De analyses van Bransford, Sherwood, Vye en Rieser (1986) laten zien dat in dergelijke gevallen het probleemoplossingsproces niet gegarandeerd tot een goed resultaat leidt. Kennis die in principe toepasbaar zou moeten zijn in zeer uiteenlopende situaties maar in feite slechts geaktiveerd wordt onder zeer beperkte condities, duiden zij aan met de term 'Inert Knowledge'.

Het onderzoek van Perfetto, Bransford en Franks (1983) vormt een illustratie van het effekt van dergelijke inerte kennis. Zij legden proefpersonen raadseltjes voor van het volgende type:

Een jonge man heeft een emstig ongeluk gehad. Hij ligt al op de operatietafel als de chirurg binnenkomt. Deze licht het laken van het gezicht van de jongen en roept: "Dat is mijn zoon, ik kan hem niet opereren". Toch is de chirurg niet zijn vader.

Hoe kan dat?

In één conditie kregen de proefpersonen voorafgaand aan de raadseltjes de clue-informatie aangeboden, die bij dit raadseltje zou luiden: 'zowel mannen als vrouwen kunnen chirurg zijn'. Daarbij kregen sommige proefpersonen wel en anderen niet de suggestie deze informatie te gebruiken bij het oplossen van de problemen. Hoe moeilijk deze kennis in de toepassingssituatie geaktiveerd wordt, blijkt wel uit het feit dat alleen de proefpersonen, die expliciet te horen kregen dat ze deze informatie konden gebruiken om de problemen op te lossen, geen moeite hadden met de taak. De anderen presteerden bijna even slecht als mensen die geen informatie vooraf hadden ontvangen.

Samenvattend kunnen we zeggen dat de interne representatie van informatie bepaald wordt door de kennis die al dan niet geaktiveerd wordt door die informatie. Of kennis die well bij een persoon aanwezig is, ook daadwerkelijk geaktiveerd wordt, hangt aan de ene kant af van kenmerken van de informatie waardoor aanwezige kennis meer of minder gemakke-

${ }^{6}$ Geproceduraliseerde kennis of procedurele kennis staat tegenover declaratieve kennis. Het onderscheid wordt wel gekarakteriseerd met de zinsneden 'weten hoe .....' voor procedurele kennis en "weten dat ...' voor declaratieve kennis. In de literatuur over het verwerven van cognitieve vaardigheden speelt het proceduraliseren van declaratieve kennis een belangrijke rol. 
lijk wordt geaktiveerd. Aan de andere kant wordit de aktivatie van kennis. bepaald door kenmerken van de kennis zelf. Kennis die gekoppeld is aan de situaties waaronder deze toepasbaar is, wordt gemakkelijker geaktiveerd dan kennis die in principe algemeen geldig is.

Het model dat we tot nu toe is geschetst, wordt geacht te gelden voor zeer uiteenlopende cognitieve processen, van simpele waarneming tot probleemoplossen. Het zou dus ook moeten gelden voor medische diagnostiek. Hoe moeten we ons nu voorstellen dat medische diagnostiek zich volgens dit model mentaal voltrekt?

Als een arts wordt geconfronteerd met een patiënt die een klacht naar voren brengt, komt er ontzettend veel informatie op hem/haar af, waaruit geselekteerd moet worden en waarop geëlaboreerd zal worden. De patiënt heeft bepaalde kenmerken, zoals zijn/haar manier van kleden, bewegen of praten. De situatie waarin de ontmoeting plaatsvindt heeft ook bepaalde kenmerken, zoals plaats (bij de patiènt thuis, in de spreekkamer of op straat), tijd en temperatuur. En de patiènt kan een klacht op diverse manieren uiten, bijvoorbeeld op een dwingende of een zeurende toon. Uit al deze informatie moet de relevante informatie worden geselekteerd. Dat is natuurlijk de klacht, maar ook het gedrag van de patiënt of kenmerken van de situatie (een verwarde patiënt in een vervuild huis bijvoorbeeld) kunnen zeer relevant zijn. Op deze geselekteerde informatie wordt geëlaboreerd. Dit kan bijvoorbeeld inhouden dat herinneringen aan vroegere contacten met deze patiënt bij de arts opkomen, of herinneringen aan vergelijkbare patiënten en hoe het met ze is afgelopen. De klacht wordt geînterpreteerd met behulp van de medische kennis, die wordt geactiveerd door informatie uit de klacht en de situatie waarin deze wordt gepresenteerd. Soms zal dit gebeuren door een diagnostische hypothese te verbinden aan de klacht, soms ook door een pre-diagnostische kwalifikatie zoals acuut of niet-acuut, iets psychisch of iets somatisch, pluis of niet-pluis (Gale en Marsden, 1982). Soms zal ook geen enkel kennisdeel door de binnenkomende informatie direkt worden geaktiveerd. In dat geval zal de arts zijn toevlucht moeten nemen tot én of andere standaard probleemoplossingsprocedure. We komen daar straks op terug.

Het zal slechts sporadisch voorkomen dat de arts reeds in dit stadium van het consult aan de geselekteerde en geellaboreerde informatie genoeg heeft en als het ware in een flits de diagnose stelt. De probleemrepresentatie ${ }^{7}$ bevat daarvoor nog te veel alternatieven en niet geexploreerde mo-

${ }^{7}$ De term 'probleemrepresentatie' staat voor interne representatie van het probleem. Evenals de interne representatie van informatie is de probleemrepresentatie een dynamisch geheel. De Groot (1946) wees reeds op dit dynamische aspekt. In plaats van de term 'probleemrepresentatie' hanteerde hij de term 'probleemontwikkeling' of 'totaalschema' van het probleem. 
gelijkheden. En niet in de laatste plaats is de diagnose ${ }^{8}$ nog onvoldoende onderbouwd. Veelal zal de diagnose die op dat ogenblik naar voren komt de status van een hypothese hebben. Crombag, De Wijkerslooth en Cohen (1977) spreken in dit verband (in navolging van Selz, 1922) van een 'schematische anticipatie' van de oplossing: een hypothese omtrent de uitkomst of oplossing van het probleem die de probleemoplosser reeds concipieert bij de eerste confrontatie met het probleem. Crombag et al. (1977) laten zien dat dit verschijnsel optreedt bij juristen die een beslissing moeten nemen in een civielrechtelijk probleem. Rechters blijken niet van een probleem naar de oplossing te redeneren. In plaats daarvan hebben zij vrijwel onmiddellijk een schematische anticipatie van de oplossing (hoe snel dat is, hangt af van de gecompliceerdheid van het probleem). Dat wil zeggen dat ze vrijwel onmiddellijk zien welke wetsartikelen en welke arresten op de casus van toepassing zijn, waarna de onderbouwing en verdere verfijning van de conclusie volgt.

De geneeskundige parallel hiervan is de diagnostische hypothese die zich aandient op grond van informatie die geselekteerd wordt bij de eerste confrontatie met een patiënt en die met behulp van verdere anamnese, fysisch-diagnostisch onderzoek en laboratoriumbepalingen nader wordt onderbouwd. Deze wijze van diagnostiek noemt Clancey (1986) "heuristic match": de associatie tussen data en hypothesen komt via heuristische associatie tot stand.

Het kan echter ook voorkomen dat er niet zo'n heuristische match plaatsvindt. Ofwel omdat de arts niet over kennis beschikt die op deze wijze geaktiveerd kan worden, ofwel omdat het ziektebeeld dat de patiënt presenteert dermate ongebruikelijk is dat het niet in de medische literatuur is beschreven. In dat geval moet de arts van andere soorten kennis gebruik maken om een hypothese te genereren omtrent de aard van de aandoening van de patiënt. In de medisch-didaktische literatuur zijn daarvoor verschillende methoden beschreven. Eén methode is het opsplitsten van het probleem in twee deelproblemen: a) waar is de aandoening gelokaliseerd (in welk orgaan of in welk orgaansysteem) en b) wat is het proces dat plaatsvindt (bijvoorbeeld een afsluiting tengevolge van een ontsteking, ruimte-innemend proces of embolie). Rasmussen (1986) maakt hetzelfde onderscheid bij de diagnostiek van mankementen in grote technische installaties. Hij spreekt over 'symptomatisch zoeken" wanneer de symptomen die bij het falende systeem kunnen worden waargenomen, worden geassocieerd met én of een aantal mogelijke diagnosen. De term topografisch zoeken' hanteert hij voor die gevallen waarin de probleemoplosser een mentaal model van het systeem zoals dat behoort te funktioneren gebruikt, en dat model toepast om hypothesen te genereren omtrent de lokatie van de fout.

8 Artsen zullen bezwaar hebben tegen het gebruik van het woord 'diagnose' zo lang er nog meerdere mogelijkheden open zijn. 'Werkdiagnose' of 'diagnostische hypothese' zullen hun voorkeur hebben. 
Welke weg de arts ook bewandelt, de probleemrepresentatie die uiteindelijk gedurende het consult tot stand komt, bevat het antwoord op de vraag 'Wat is er met deze patiënt aan de hand?". Het antwoord op deze vraag is de diagnose, hoe globaal deze misschien ook gesteld is; of eventueel de differentiaal-diagnose. Maar de probleemrepresentatie bevat niet alleen deze diagnose. Ook de informatie op grond waarvan die diagnose is gesteld en de kennis die is geaktiveerd om de diagnose te stellen dan wel te onderbouwen, maken deel uit van de uiteindelijke representatie van het probleem.

\section{Verschillen tussen experts en novieten}

Onderzoekingen waarin verschillen tussen experts en novieten in een bepaald terrein werden onderzocht, laten resultaten zien die in belangrijke mate overeenkomen met de resultaten van bovengeschetste experimenten, waarin de gevolgen van het niet-aktiveren van kennis werden gedemonstreerd. Deze overeenkomst is natuurlijk niet verwonderlijk, want als er weinig kennis is, zoals dat bij novieten het geval zal zijn, dan valt er ook weinig te aktiveren. Glaser (1986) neem echter een wat andere positie in. Volgens Glaser kampen novieten met het probleem dat wel aanwezige kennis vaak niet geaktiveerd wordt door de problemen die ze worden voorgelegd. Hun kennis is slecht toegankelijk en weinig gekoppeld aan de condities waaronder ze van toepassing is. Volgens Glaser zouden verschillen tussen experts en novieten niet zo zeer liggen in de hoeveelheid kennis die men bezit, maar zouden ze vooral terug te voeren zijn op verschillen in struktuur in de kennis. Sommige onderzoekingen bieden direkte ondersteuning voor deze stelling. In onderzoek van Bloom en Broder (1950) en van Allwood en Montgomery (1981, 1982) bleek bijvoorbeeld dat novicen moeite hadden om zich in probleemoplossingssituaties relevante kennis te binnen te brengen en dat ze onder zulke condities soms zelfs niet meer wisten dat ze dat soort kennis bezaten.

Het cruciale verschil tussen experts en novieten is in deze optiek dus het verschil in kennisorganisatie. Daaruit vloeit een verschil voort in kwaliteit, volledigheid en samenhang van de probleemrepresentatie, hetgeen op haar beurt de efficiëntie van het verdere denkproces sterk beïnvloedt. Een duidelijk verschil in probleemrepresentatie tussen experts en novieten is reeds vele malen gedemonstreerd (Larkin, McDermott, Simon en Simon, 1980; Chi, Feltovich en Glaser, 1981; Chi, Glaser en Rees, 1982; Larkin, 1983; Glaser, 1985). In het onderzoek van Chi, Glaser en Rees (1982) bleek bijvoorbeeld dat de representatie die novieten vormden van een mechanicaprobleem georganiseerd was rond de voorwerpen die feitelijk in een probleem figureren (hefbomen, katrollen of hellende vlakken). Hun representatie was veel oppervlakkiger dan die van experts in de mechanica die de problemen veel meer in termen van onderliggende principes karakteriseerden (bijvoorbeeld de tweede wet van Newton of de wet van behoud van energie). Chi, Glaser en Rees (1982) konden op een 
direkte wijze laten zien dat dit verschil in representatie samenhing met een verschil in kennisstruktuur. De kennis van de experts was in tegenstelling tot de novieten, waar het de relevante natuurkundige principes betrof, gekoppeld aan de condities waarin deze principes kunnen worden toegepast. Verder was de kennis van de noviet even uitgebreid als de kennis van de expert. Deze resultaten ondersteunen dus de theorie van Glaser dat verschillen tussen experts en novieten niet zo zeer hun oorzaak vinden in het feit dat novieten te weinig kennis over een bepaald onderwerp bezitten, maar dat deze verschillen toe te schrijven zijn aan verschillen in struktuur van de kennis.

Anderson heeft in 1982 op basis van de theorie van Fitts (1964) een model ontwikkeld, het ACT*-model (Adaptive Control of Thought), dat de ontwikkeling van noviet tot expert simuleert. Lesgold (1984) laat zien dat deze theorie ook heel goed toepasbaar is in de geneeskunde. We bespreken hier de latere variant die Anderson in 1987 publiceerde. Dit model is een vereenvoudiging van het oorspronkelijk model van 1982 dat nog een aantal andere, onnodig en onjuist gebleken leerprincipes bevatte. Anderson (1987) ziet de ontwikkeling van beginner tot expert als volgt. In het vroegste stadium van het leerproces wordt declaratieve kennis opgebouwd. Door leerboeken te bestuderen, adviezen en commentaren van medestudenten en docenten in zich op te nemen wordt dit kennisbestand verder uitgebouwd. Om deze declaratieve kennis te kunnen toepassen, worden algemene probleemoplossingsstrategieën gebruikt. Probleemoplossen in dit stadium wordt daardoor gekenmerkt door een moeizaam zoeken en een weinig gestroomlijnd proces. Dit stadium noemt Anderson de cognitieve fase.

In de fase van het leerproces die daarna volgt, de associatieve fase, wordt de declaratieve kennis gecompileerd ${ }^{9}$. Deze compilatie gebeurt in twee stappen. Tijdens de eerste stap worden er in het geheugen neerslagen gevormd van de toepassing van een element van de declaratieve kennis met daarbij de condities, die het gebruik van die kennis succesvol maakten. Op deze wijze ontstaan produkties ${ }^{10}$ van het type 'als ( $\mathrm{x}$ het

9De termen 'compileren' en 'compilatie' zijn aan de informatica ontleend. Een 'com-
piler' is een computerprogramma dat een ander programma dat in een hogere program-
meertaal is geschreven, omzet in code die door de machine gelezen kan worden. Dit
vertaalde programma wordt naar schijf of band weggeschreven. Willen we dit program-
ma uitvoeren, dan is het al vertaald. Hierdoor wordt de uitvoeringstijd verkort. 'Com-
pilatie' in de cognitieve psychologie wil dan ook zeggen: omzetten van kennis maar een
andere representatiewijze waardoor de toepassing van die kennis aanzienlijk versneld
wordt. Deze betekenis wijkt af van het daagse spraakgebruik, waarin een 'compilatie'
een bundeling is van een aantal stukken, afkomstig uit verschillende bronnen, zonder
dat er sprake is van een bewerking of van integratie van de delen.
10produkties of produktieregels zijn basiselementen die vooral geschikt zijn om gepro-
ceduraliseerde kennis te representeren. Ze hebben de vorm 'ALS <aan conditie C is
voldaan> DAN <voer aktie A uit>. In hoofdstuk 3 wordt hierop uitgebreider ingegaan. 
geval is), dan (pas toe: kenniselement a) De tweede stap bestaat uit een proces dat 'compositie' wordt genoemd. Bij deze stap worden twee succesvolle produkties die na elkaar werden uitgevoerd, samengevoegd tot één produktie. Deze compilatie en compositie van kennis brengt een sterke verkorting van het probleemoplossingsproces met zich mee. Door vaak problemen op te lossen worden nieuwe produkties gevormd en oude produkties die in meerdere situaties toepasselijk bleken, worden versterkt. Dit versterken van produkties leidt ertoe dat ze bij een nieuw probleem een hogere kans op toepassing zullen krijgen.

Ondanks de veranderingen die Anderson zelf al in zijn model heeft aangebracht, behoeft het nog een belangrijke aanvulling. Jansweijer (1988) laat bijvoorbeeld zien dat in het model wordt verondersteld dat de associatieve fase wordt afgesloten met een volledig, declaratief kennisbestand. Er wordt dus pas begonnen met de toepassing van kennis als alle noodzakelijk voorkennis aanwezig is. Deze aanname is zeer in tegenspraak met het leergedrag dat mensen in de werkelijkheid ten toon spreiden. D.A. Norman (1978) wijst er op dat door het toepassen van kennis inzicht ontstaat in de hiaten die er nog zijn in de kennis. Dit brengt de persoon ertoe de te leren informatie opnieuw te bestuderen. Het leren van declaratieve kennis is dan ook geenszins het automatische en soepel verlopende proces zoals Anderson dat aanneemt (Elshout, 1987). Integendeel, het kan veel inspanning, zelfreflectie en doelgericht handelen van de lerende vereisen. Het model van Rumelhart en Norman (1978) doet hieraan wel recht.

Rumelhart en Norman (1978) nemen aan dat bij het opdoen van kennis, of het nu declaratieve of procedurele kennis is, drie leerprincipes werkzaam zijn. Het eerste is 'accretion': het toevoegen van nieuwe elementen aan een kennisbestand. Dit kan het eenvoudige stampwerk zijn dat wel tot vermeerdering van kennis, maar niet tot vermeerdering van begrip leidt. Daarvoor is een tweede type leren nodig, namelijk 'restructuring': In dit geval wordt er geen nieuwe kennis toegevoegd, maar wordt bestaande kennis (naar aanleiding van stimulerende vragen, socratische gesprekken of door de toepassing van de kennis bij het uitvoeren van een taak of oplossen van een probleem) opnieuw doordacht. Nieuwe verbanden worden gelegd en het inzicht in de materie wordt vergroot. Naast deze twee processen postuleren Rumelhart en Norman een derde proces, namelijk 'tuning'. Door tuning worden reeds aanwezige kennisstrukturen steeds beter aangepast aan de situaties waarin ze moeten worden toegepast. Met toenemende ervaring gaat de toepassing van de kennis steeds sneller; een voortschrijdende automatisering treedt op. Deze drie processen treden niet sequentieel op. Norman (1978) veronderstelt, dat de eerste stadia van een leerproces gekenmerkt worden door accretion, maar er zal ook enige herstrukturering (zie ook Frijda, 1978) en tuning plaatsvinden. In de fase die daarop volgt, neemt het aandeel van de accretion drastisch af en is herstrukturering het dominante proces. Hierna zal een fase van hernieuwde accretion volgen, terwijl de hoeveelheid herstruktureringsarbeid drastisch daalt en de hoeveelheid tuning begint te 
stijgen. In de laatste fase vindt voornamelijk tuning plaats. Waar Anderson dus é́n cognitieve fase veronderstelt, laten Norman en Rumelhart zien dat in die fase meerdere leerprincipes in wisselende verhoudingen werkzaam zijn. Over het laatste stadium van leren bestaat weinig verschil van mening. Afstemming van de kennis op toepassingssituaties en automatisering schijnen daarin het belangrijkste te zijn.

Samenvattend kunnen we dus stellen dat het verwerven van expertise gepaard gaat met toename van en strukturele veranderingen in de kennis, een stadium in de kennisverwerving dat in dit proefschrift zal worden aangeduid met de term 'kennisaccumulatie'. Daarna wordt de kennis in toenemende mate afgestemd op de verschillende mogelijke toepassingssituaties en treedt automatisering op. Dit stadium duiden we aan met de term 'afstemming' (tuning). In het historisch overzicht werd geconcludeerd dat in de huidige cognitieve psychologie leren probleemoplossen gelijk gesteld is aan het verwerven van expertise in een bepaald domein. Nadat we bovenstaande theorieën en onderzoeksresultaten hebben besproken, kunnen we daar nu dus de conclusie aan verbinden dat leren probleemoplossen gepaard gaat met herstrukturering, toepassingsgericht maken en automatisering van de kennis.

\section{Methoden van onderzoek}

Twee concepten vervullen in dit proefschrift een dominante rol: de interne representatie van een probleem, het kermbegrip in de informatieverwerkingstheorie, en de struktuur van de kennis die daarbij wordt toegepast. Van deze twee begrippen nemen we aan dat ze nauw samenhangen met de ontwikkeling van expertise 11 . In de nu volgende paragrafen zul-

11 Ook de variabele 'expertiseniveau' of 'mate van ervaring' is methodologisch gezien niet onproblematisch. We schatten dat er ten minste 12 jaar studie en ervaring nodig zijn voordat iemand als expert in de geneeskunde kan worden aangemerkt. Deze periode is dermate lang dat het bijna onmogelijk is om in dit terrein longitudinaal onderzoek naar expertisevorming te doen. Het is dan ook bijna onvermijdbaar gebruik te maken van de cross-sectionele methode: de inteme representaties en de struktuur van de gebruikte kennis van proefpersonen van verschillende mate van expertise worden met elkaar vergeleken. Deze methode van onderzoek wordt wel het expert-novietparadigma genoemd. Voordeel is dat telescopering in de tijd plaatsvindt. Er kleven echter ook verschillende nadelen aan: a) Het is een niet-experimentele methode en is daarmee niet geschikt om causale relaties aan te tonen. b) Het doel van veel onderzoekingen binnen dit paradigma is de ontwikkeling van beginner tot expert te beschrijven, maar de methode beperkt zich tot een onderzoek van een aantal toestanden en hun kenmerken die zich tijdens die ontwikkeling voordoen. Hoe die ontwikkeling zich voltrekt, moet dus worden afgeleid uit de toestandsbeschrijvingen. Een ongelukkige keuze van de meetpunten kan daarvoor verregaande gevolgen hebben. c) Bij een cross-sectie methode wordt niet de ontwikkelingsgang van dezelfde proefpersonen onderzocht; maar er worden bijyoorbeeld verschillende jaargroepen met elkaar vergeleken. De proefpersonen in deze groepen verschillen daardoor niet alleen in de mate van expertise, maar ook op andere 
len we ingaan op de vraag hoe ze kunnen worden onderzocht. Aan beide onderwerpen wordt een paragraaf besteed.

\section{Methoden om de interne representatie te onderzoeken}

De interne representatie van binnenkomende informatie, die in het hiervoor geschetste model van informatieverwerking zo'n belangrijke rol vervult, laat zich niet eenvoudig door middel van direkte methoden onderzoeken. Daarvoor is de interne representatie te vlottend en vloeiend van aard. De interne representatie van informatie weerspiegelt eerder de voortgaande gedachtenstroom dan dat het de neerslag van die informatie in het geheugen vormt. Immers, de interne representatie betreft informatie waaraan vaak slechts voor korte duur aandacht wordt besteed ${ }^{12}$. Door dit vloeiende karakter van de interne representatie zou men dus het liefst een methode gebruiken die direkte uitlezing uit het korte termijn geheugen mogelijk maakt.

De meest direkte, on-line toegepaste methode om de interne representatie te onderzoeken is de methode van hardop denken (Elshout, 1978; Ericsson en Simon, 1984; Breuker, Elshout, Van Someren en Wielinga, 1986). Bij deze methode wordt de proefpersoon gevraagd alles wat hij of zij denkt, hardop uit te spreken. Ericsson en Simon betogen dat bij een dergelijke opdracht de proefpersoon datgene verwoordt dat zich in de focus van de aandacht bevindt. Niet zo zeer de verwerking zelf, maar de resultaten van de opvolgende verwerkingsstappen worden verwoord. Processen die buiten de focus van het aandachtmechanisme vallen, zijn niet verwoordbaar. Dit geldt dus zowel voor de automatische, basale cognitieve processen als voor de herkenning van stimuli en ook voor geautomatiseerde hogere processen. Ook stimuli die zorgen voor een plotselinge verplaatsing van de aandacht naar iets heel anders, zal men niet in een verbale weergave van het denkproces tegenkomen. Immers, ze bevinden zich op dat ogenblik nog niet in het centrum van de aandacht. Het volgende ogenblik, als de aandacht zich verplaatst heeft, kunnen ze wel verwoord worden. Ericsson en Simon noemen als voorbeelden van dit soort stimuli plotselinge, harde geluiden of bewegingen in de visuele periferie.

Helaas is niet alle informatie even gemakkelijk verwoordbaar. Is de informatie in het korte duur geheugen sterk verbaal getint, dan is het niet moeilijk deze onder woorden te brengen. Daartegenover staat de perceptuele informatie, waarbij het vaak in belangrijke mate van de scholing van de proefpersoon afhangt of deze daarvoor een hanteerbaar vocabu-

variabelen als vooropleiding en geboortejaar. Bovendien heeft een methode waarin groepen met elkaar worden vergeleken het nadeel dat deze meer ernor met zich meebrengt dan een methode die gebruik maakt van herhaalde metingen.

${ }^{12}$ Eriesson en Simon (1984) gebruiken hiervoor de term theeded information'. In hun opvatting is dit ongeveer synoniem aan informate waaraan aandacht wordt besteed (attended to') of informatie die aanwezig is in het korte duur geheugen (stored in short term memory). 
larium tot zijn beschikking heeft (bijvoorbeeld namen voor gelaatskleuren die kunnen worden onderscheiden, voor huidaandoeningen, voor muziekaccoorden of voor geuren). Een andere factor die het verbaliseren van gedachten bemoeilijkt, is de snelheid waarmee het resultaat wordt bereikt. Een plotseling doorbrekend inzicht, zoals dat werd onderzocht door de Gestaltpsychologen, is van het ene op het andere ogenblik aanwezig zonder dat de probleemoplosser zich bewust is van enige tussenstappen. We zullen ze dan ook niet horen tijdens het hardop denken.

Ericsson en Simon laten zien dat het probleemoplossingsproces niet meer tijd in beslag neemt wanneer de proefpersoon hardop denkt. Pas wanneer de cognitieve belasting die met een taak gepaard gaat erg hoog wordt, wordt de verbale rapportage ervan geschaad. Het protocol wordt onvollediger of de proefpersoon voegt retrospecties in, die het denkproces onder deze condities verlengen.

De methode van hardop denken is inmiddels gebruikt in zeer veel onderzoekingen, vooral daar waar het gaat om onderzoek van probleemoplossen. De Groot (1946) gebruikte de hardop-denk methode om het denken van de schaker te onderzoeken. Newell en Simon (1972) gebruikten de hardop-denk methode om probleemoplossingsstrategieën te onderzoeken in diverse domeinen: logica, schaken en oplossen van lettersommen. Ook het effekt van kennisgebruik op de interne representatie is op deze wijze onderzocht. Simon en Simon (1979) lieten bijvoorbeeld zien dat het uitgangspunt, waarmee een probleem wordt aangepakt, van invloed is op het soort kennis dat dien ten gevolge wordt geaktiveerd.

Een tweede methode om de interne representatie van informatie te onderzoeken is een post hoc methode: de 'recall' methode. Deze methode gaat ervan uit dat datgene waaraan aandacht wordt besteed ("heeded information') ook onthouden wordt. In het lange duur geheugen ontstaan de geheugensporen van de informatie, die in het korte duur geheugen bewerkingen heeft ondergaan. Hoe langer de informatie in het korte duur geheugen aanwezig is geweest, hoe sterker die geheugensporen zijn en hoe groter de kans dat de betreffende informatie kan worden gereproduceerd. Daarbij bepalen de bewerkingen die op de informatie hebben plaatsgevonden, de manier waarop de informatie wordt onthouden. Aangezien er een nauwe relatie bestaat tussen de manier waarop informatie in het lange duur geheugen ligt opgeslagen en de manier waarop deze wordt gereproduceerd, impliceert dit dat de manier waarop informatie wordt gereproduceerd (hoeveelheid, type, fouten, samenvoegen van elementen) indicatief is yoor de wijze waarop ze werd gerepresenteerd (Ericsson en Simon, 1984, pp 182-188).

Het inmiddels klassieke onderzoek van Bransford, Barclay en Franks (1972) kan beschouwd worden als een interessante illustratie van het gebruik van deze recallmethode om de interne representatie te onderzoeken. Zij lieten proefpersonen zinnen lezen als:

Three turtles rested on a floating $\log$ and a fish swam beneath it. 
In de daama volgende recallfase waren de proefpersonen niet in staat te bepalen welke van de volgende zinnen ze nu eigenlijk hadden gelezen:

Three turtles rested on a floating $\log$ and a fish swam beneath it. of

Three turtles rested on a floating log and a fish swam beneath them.

Beide zinnen werden even vaak herkend. Dit effekt trad echter niet op wanneer de beginzin luidde:

Three turtles rested beside a floating $\log$ and a fish swam beneath it.

Inferentie- en elaboratieprocessen op de input leiden er dus toe dat informatie die op syntactisch niveau nauwelijks van andere informatie afwijkt, op zeer verschillende wijzen wordt gerepresenteerd.

De recallmethode is door meerdere onderzoekers gebruikt om de interne representatie te onderzoeken. Dit gebeurde vooral daar waar men niet zo zeer geïnteresseerd was in de dynamiek van de representatie, maar meer in de representatie zoals die uiteindelijk tot stand komt. Dit is met name het geval bij cognitieve processen als tekstbestudering waarbij de toepassing van kennis op verschillende wijzen werd gemanipuleerd. Schmidt (1984) onderzocht bijvoorbeeld het effekt van de aktivatie van voorkennis op de interne representatie van nieuwe informatie. Vele onderzoekers, onder wie R.C. Anderson (1977, 1978), Anderson, Reynolds, Schallert en Goetz (1977), Bower (1978) en Pichert en Anderson (1977), onderzochten op deze wijze de invloed die uitgaat van het soort kennis dat wordt geaktiveerd op de interne representatie.

\section{Methoden om de struktuur van de toegepaste kennis te onderzoeken}

De vraag naar de struktuur van de kennis die is toegepast bij het oplossen van een probleem heeft nauwe verwantschap met de vraag naar de kenmerken van de interne representatie van dat probleem. Immers de interne representatie omvat naast informatie uit het probleem ook de geaktiveerde kennis en de elaboraties en inferenties die met betrekking tot dat probleem zijn gemaakt. Het accent bij beide vragen is echter duidelijk anders. Bij onderzoek naar de interne representatie wordt de aandacht gericht op de informatie en op de inferenties en elaboraties. Bij het onderzoek naar de kenmerken van de kennis die door het probleem is geakti veerd, gaat de primaire aandacht uit naar de kennis waarover de persoon beschikt en die geaktiveerd en geinstantieerd is door het voorgelegde probleem. Het is echter niet verwonderlijk dat de methoden die in beide gevallen worden gebruikt nauwe verwantschap met elkaar vertonen, ja zelfs ten dele elkaar overlappen.

De eerste methode die we bespreken is de hardop-denk methode, die, behalve bij onderzoek naar kenmerken van de kennis, ook gebruikt wordt bij onderzoek naar de interne representatie (zie de vorige paragraaf). Het verschil tussen beide toepassingen betreft de gebruikte analysemethode die het mogelijk maakt hypothesen omtrent de struktuur van de kennis te onderzoeken. Feltovich, Johnson, Moller en Swanson (1984) gebruikten 
hardop-denk protocollen om na te gaan hoe de kennis van hun proefpersonen omtrent een nauw omschreven deel van de kindercardiologie was georganiseerd. Rond de meest plausibele diagnose van de gebruikte casus identificeerden zij groepen van ziektebeelden die gemakkelijk met elkaar yerward kunnen worden: dit zijn de meest voor de hand liggende alternatieven voor de diagnose. Vervolgens werd in de casus aangegeven met welke informatie tussen de verschillende hypothesen kan worden gediscrimineerd zodat uiteindelijk één diagnose overblijft. Het ideale diagnostische pad dat op deze wijze ontstaat vergeleken zij met de weg die de verschillende proefpersonen waren gegaan.

Een tweede methode om de struktuur van de gebruikte kennis te onderzoeken maakt gebruik van én of meer rechtstreekse vragen. Deze methode wordt wel 'direct probe technique' genoemd. In het onderzoek naar medisch probleemoplossen is deze techniek met name gepropageerd door de groep van onderzoekers rond Patel en Groen (Patel en Groen, 1986; Patel, Evans en Chawla, 1986; Patel, Arocha en Groen, 1986). Zij legden proefpersonen een casusbeschrijving voor (dit is de beschrijving van een patiënt met een bepaalde aandoening) en vroegen hen een diagnose te genereren. Daarna werd de proefpersonen gevraagd de gegevens die in de casusbeschrijving werden genoemd te verklaren in termen van het pathofysiologisch proces dat daaraan ten grondslag ligt. Patel en Groen zijn van mening dat op deze wijze de kennis die geaktiveerd was bij het tot stand komen van de probleemrepresentatie, opnieuw geaktiveerd wordt. Met behulp van een speciale analysemethode die in hoofdstuk 3 wordt beschreven, is het vervolgens mogelijk de kenniselementen en de relaties daartussen te identificeren en in kaart te brengen.

De derde methode is de methode van 'priming'. De primingsmethode werkt als volgt. Eerst worden kenniselementen door een korte taak geaktiveerd. Zo'n taak kan diverse zaken inhouden: concepten benoemen, associaties genereren of een paar zinnen lezen en interpreteren. Daarna volgt een andere taak waarin de priming tot uitdrukking kan komen. Dit kan bijvoorbeeld een eenvoudige benoemings- of herkenningstaak zijn. De snelheid, waarmee die taak kan worden uitgevoerd, laat zien of de betrokken kenniselementen tijdens de primingstaak geaktiveerd waren. De methode maakt hiertoe gebruik van twee eigenschappen van kennis. Ten eerste, dat kennis die geaktiveerd is geweest, gedurende enige tijd daaropvolgend gemakkelijk opnieuw aktief kan worden. En ten tweede, dat de aktivatie zich verspreidt naar de kenniselementen die verbonden zijn met het element dat direkt werd geaktiveerd. Hierdoor kunnen ook deze elementen gedurende enige tijd sneller opnieuw geaktiveerd worden.

Tot nu toe is de primingsmethode vooral gebruikt om theoretische noties omtrent kennisstrukturen in het algemeen te onderzoeken. Voorbeelden zijn het werk van Meyer en Schvaneveldt (1971) en Ratcliff en McKoon (1981).

Over de validiteit van deze drie methoden is nog niet veel te zeggen. De nauwe verwantschap tussen de concepten 'geaktiveerde kennis' en 
'probleemrepresentatie' suggereert dat hoe dichter de methode aansluit bij de feitelijke probleemrepresentatie hoe meer men erop kan vertrouwen dat ook daadwerkelijk de gébruikte kennis wordt onderzocht. Het meest duidelijk is dat het geval bij de hardop-denk methode. Bij de primingsmethode loopt deze relatie iets minder in het oog. De methode is echter gebaseerd op een uitgebreid bestudeerd en vele malen gerepliceerd verschijnsel. De claim dat op deze manier de gebruikte kennis kan worden onderzocht is dus goed onderbouwd. Anders ligt dat bij de rechtstreekse methode die Patel en Groen (1986) hanteren. De opdracht bij deze methode is het pathofysiologisch proces te beschrijven dat aan de verschijnselen van de patiënt ten grondslag ligt, zou de gebruikte kennis reaktiveren. Deze aanname wordt echter nergens onderbouwd en is ook niet expliciet onderzocht.

Samenvattend: doel van dit intermezzo was de algemene theoretische uitgangspunten op het gebied van menselijke informatieverwerking en kennisverwerving te schetsen waarbinnen de theorievorming op het terrein van de expertiseontwikkeling in de geneeskunde een plaats kan krijgen. Struktuur van de kennis, struktuurveranderingen, kennisaktivatie en interne representatie zijn daarbij cruciale begrippen. In het methodologische deel van dit intermezzo zijn methoden besproken om de elementen van het model in kaart te brengen. Beschreven zijn methoden om de probleemrepresentatie te onderzoeken, namelijk hardop denken en free recall, en methoden om de struktuur van de kennis te exploreren: wederom hardop denken, priming en rechtstreeks onderzoek. Met deze methoden kunnen verschillen tussen personen met verschillende maten van expertise worden onderzocht. We zullen ze in de volgende paragraaf weer tegenkomen.

\section{EXPERTISE IN DE GENEESKUNDE: EEN OVERZICHT VAN ONDERZOEK IN DIT DOMEIN}

In deze paragraaf wordt het onderzoek besproken dat tot nu toe op het gebied van medische expertise heeft plaatsgevonden. Hiermee zal worden nagegaan of de ideeën van informatieverwerking en expertiseverwerving, die in de vorige paragraaf werden ontvouwd, een geneeskundige invulling kunnen krijgen.

We beginnen met een beschrijving van de oudere studies die in de jaren 70 hebben plaatsgevonden. Hierin hield men zich bezig met onderzoek naar verschillen in denkproces tussen artsen en studenten en tussen goede en minder goede artsen. De resultaten, of liever gezegd het gebrek aan resultaten, van deze onderzoekingen vormen het keerpunt in het onderzoek op dit terrein. Daarna volgde het onderzoek dat zich meer richtte op de verschillen in kenmerken van de gebruikte kennis. Bij de 
bespreking van deze meer recente onderzoekingen zal geprobeerd worden een antwoord op twee vragen te vinden:

a) Zijn er verschillen tussen experts en novieten in de manier waarop zij een probleem representeren?

b) Zijn er verschillen in de kennis die geaktiveerd wordt bij het oplossen van een probleem?

Nadat de antwoorden op deze vragen zijn geinventariseerd, zal een poging worden ondernomen om tot een eerste aanzet voor een theorie omtrent de ontwikkeling van medische expertise te komen.

De geschiedenis van het onderzoek naar probleemoplossen in het medisch domein vertoont duidelijke parallellen met het onderzoek in andere domeinen. Lange tijd is men ook in dit domein uitgegaan van de opvatting dat probleemoplossen en kennis onafhankelijke entiteiten zijn. De redenering daarbij gaat ongeveer als volgt:

"Indien men zich de vraag stelt wat men in het onderwijs moet overdragen, dan richt zich dat op twee facetten: a) de inhoud van het vakgebied en b) de methoden waarmee men voorkomende problemen (in dat vakgebied) kan oplossen. In de geneeskunde zijn met betrekking tot dat eerste facet bibliotheken vol geschreven. Het tweede facet krijgt veel minder aandacht en wordt meestal slechts terloops aangeduid. Näar mijn mening is dit een onderwaardering van dit aspekt. Indien men miet in staat is de - probleem-oplossende - processen te traceren, hoe kan men dan de doeltreffendheid (en de doelmatigheid) van het proces te weten komen, of de waarde die men toe moet kennen aan de uitkomst ervan." (Ridderikhoff, 1986, pp 278).

In het onderwijs steekt deze wens om zich behalve met kennis ook met probleemoplossen als afzonderlijke entiteit bezig te houden herhaaldelijk de kop op. Maar ook wanneer het gaat om het beoordelen van studieprestaties wordt het vaak niet voldoende geacht alleen de kennis te beoordelen. Ook aan probleemoplossingsvaardigheden zou aandacht moeten worden besteed. In Nederland gebeurt dit nergens systematisch, in de Verenigde Staten maakt probleemoplossen (problem solving, clinical competence) deel uit van het artsexamen. Diverse soorten simulaties van het echte arts-patiênt-contact (papieren patiëntproblemen, diagnostische managementproblemen, computersimulaties) worden gebruikt om probleemoplossingsvaardigheden te beoordelen. Gerritsma en Smal (1982) geven een zeer gedegen overzicht van onderzoekingen op dit terrein.

Deze scheiding tussen kennis enerzijds en probleemoplossen anderzijds bracht ook met zich mee dat degenen die zich met probleemoplossen bezighouden, zich richten op kenmerken van het probleemoplossingsproces. Voorbeelden hiervan zijn de onderzoekingen die gedaan zijn aan $\mathrm{Mi}$ chigan State University in East Lansing, Michigan, en aan McMaster University in Hamilton, Ontario, onder leiding van respectievelijk Elstein en Barrows.

Elstein, Shulman en Sprafka (1978) deden een onderzoek bij wat zij 'criterial physicians' noemen. Dit zijn artsen die volgens hun collega's 
aangemerkt kunnen worden als de beste diagnostici in hun omgeving. Met behulp van simulatiemethoden die varieerden in mate van levensechtheid (simulatiepatiënten en papieren patiëntsimulaties) onderzochten zij de probleemoplossingsmethoden van deze uitmuntende artsen en vergeleken die met de vaardigheden, strategieën en taktieken van een andere groep, gewone artsen, die gerecruteerd was in dezelfde ziekenhuizen. Doel van het onderzoek was om daarmee een empirische basis te leggen voor een rationele benadering van onderwijs en evaluatie in de geneeskunde. Het onderzoek van Elstein et al. leidde tot een aantal opvallende resultaten.

Ten eerste bleken de artsen op een geheel andere manier te werk te gaan dan men tot dan toe altijd aannam en ook aan studenten voorhield als zijnde de ideale methode. Men leerde de studenten eerst een speciële anamnese (specifiek gericht op de klacht) af te nemen, daarna een volledige tractusanamnese (gericht op alle tracti of orgaansystemen die ziekte kunnen veroorzaken) en lichamelijk onderzoek. Nadat deze fase van informatieverzamelen is afgesloten, dient de informatie gegroepeerd te worden en wordt er een differentiaal diagnose opgesteld. Op grond hiervan dient dan besloten te worden welke aanvullende informatie nodig is om tot een conclusie te komen. Dit kan bestaan uit verder specifiek lichamelijk onderzoek, Röntgen-foto's, laboratoriumbepalingen etc.

In tegenstelling tot wat wordt onderwezen, bleken alle artsen al voordat alle informatie is verzameld hypothesen te genereren over de aandoening van de patiënt. Deze hypothesen stellen zij dus niet uit tot na beëindiging van de anamnese en het onderzoek. In plaats daarvan genereren de artsen de eerste hypothese(n) al na zeer korte tijd, nadat ze de klacht en enige gegevens hebben vernomen. Deze eerste hypothesen sturen het verdere informatiezoekproces. Het aantal hypothesen dat wordt overwogen, is beperkt. Nieuwe informatie wordt ingepast in hetgeen reeds is gegenereerd, waardoor de uitkomst soms niet optimaal is.

Verder bleek dat er geen systematisch verschillen geconstateerd konden worden tussen de gewone en de uitmuntende artsen. Bij alle artsen bleek de diagnostische effektiviteit sterk samen te hangen met de aard van het voorgelegde probleem. En als laatste conclusie formuleren Elstein et al. dat niet het gebruik van een bepaalde oplossingsstrategie, maar kennis van en ervaring met een ziektebeeld aan de wortel liggen van medische competentie en medisch probleemoplossen.

Ook Barrows, Feightner, Neufeld en Norman (1978) hadden zich tot doel gesteld de probleemoplossingsstrategieën van medische experts te karakteriseren. Zij maakten daartoe gebruik van een expert-novietparadigma. De resultaten van dit onderzoek vertonen grote overeenkomst met de resultaten die Elstein, Shulman en Sprafka (1978) rapporteerden, namelijk dat er ook tussen ervaren artsen en studenten geen verschillen geconstateerd kunnen worden in het probleemoplossingsproces. Het tijdstip waarop de eerste hypothesen worden gegenereerd en de manier waarop ze worden geverifieerd dan wel gefalsificeerd verandert niet onder invloed van toenemende kennis en ervaring. Die verandering geldt echter wel voor de inhoud van de hypothesen die tijdens dat proces worden gegene- 
reerd. De inhoud van de hypothesen blijkt sterk gecorreleerd te zijn met de uitkomst van het probleemoplossingsproces - in termen van de juistheid van de diagnose, adequaatheid van aanvullend onderzoek en behandeling. Deze hangen wel samen met expertiseniveau.

Gerritsma en Smal (1982) lieten verder zien dat het globale probleemoplossingsproces en het resultaat hiervan niet samenhangen met de specialisatie van de arts - huisartsgeneeskunde of interne geneeskunde.

De resultaten van deze onderzoekingen vertonen nauwe parallellen met onderzoek naar het probleemoplossingsproces in het schaakdomein (De Groot, 1946; 1965). Zowel in het medisch domein als in het domein van het schaken bleek het niet mogelijk beginners en experts van elkaar te onderscheiden uitsluitend op grond van kenmerken van het probleemoplossingsproces. Een verschuiving van de onderzoeksvraagstellingen in dit domein van het probleemoplossingsproces naar probleemrepresentatie en de variabelen die daarmee samenhangen lag dan ook voor de hand.

\section{Verschillen in interne representatie bij novieten en experts}

Veel van het onderzoek dat zich richt op de relatie tussen mate van expertise en kenmerken van de interne representatie maakt gebruik van de recallmethode. Norman, Jacoby, Feightner en Campbell (1979) lieten hun proefpersonen (vijf tweedejaars medische studenten, vijf eerstejaars en vijf derdejaars assistenten 'family medicine'13 , en vijf 'family physicians') een viertal casusbeschrijvingen bestuderen. Daarna werd ze gevraagd op te schrijven wat ze zich van de casus konden herinneren en een diagnose te stellen. Twee van deze casus konden gediagnosticeerd worden, de andere twee niet. Norman et al. vonden geen verschillen in de hoeveelheid casusinformatie die proefpersonen van verschillend expertiseniveau zich konden herinneren. Wanneer echter de bestuderingstijd in de maat voor recall werd verdisconteerd door de hoeveelheid recall te delen door de bestuderingstijd, veranderde dit beeld. $\mathrm{Nu}$ yonden zij verschillen die samenhingen met het expertiseniveau van de proefpersonen en met de diagnosticeerbaarheid van de casus. Norman et al. melden geen relatie tussen recall en juistheid van de diagnose. Of er dus sprake is van een verband tussen probleemrepresentatie en uitkomst van het probleemoplossingsproces is niet duidelijk.

Boshuizen en Claessen (1981) en Claessen en Boshuizen (1985) gebruikten een vergelijkbare onderzoeksopzet. $\mathrm{Zij}$ onderzochten naast verschillen in recall en recall gecorrigeerd voor de bestuderingstijd ook verschillen in samenhang in de recall. In beide onderzoekingen werd een toenemende samenhang in de probleemrepresentatie gevonden.

13 Huisartsgeneeskunde en family medicine (ook wel general practice genoemd) zijn niet aan elkaar gelijk te stellen, vandaar dat family medicine onvertaald wordt gelaten. De verschillende medische curricula in Canada en de VS verschillen nogal van elkaar en van de Nederlandse. Voor een goed begrip van het expertiseniveau van de proefpersonen moet hiermee rekening worden gehouden. 
Muzzin, Norman, Jacoby, Feightner, Tugwell en Guyatt (1982) gebruikten in een vervolgonderzoek vier cardiorespiratoire problemen in een typische en een atypische vorm. Deze acht problemen presenteerden zij aan twee groepen proefpersonen: acht internisten en acht tweedejaars studenten. De casus waren opgenomen op geluidsband en in random volgorde voorgelegd aan de proefpersonen die de tekst van papier konden meelezen. Wederom werd er geen verschil in recall gevonden tussen de experts en de novieten. Aangezien Muzzin et al. gebruik maakten van een mondelinge recallprocedure was het mogelijk na te gaan hoe de denkpauzes in de recall verdeeld waren. Lengte en spreiding van de denkpauzes geven een indicatie voor het gemak waarmee de recall plaatsvindt en voor de mate van samenhang van de representatie. Uit deze analyse bleek dat het aantal casusitems per 'recall run' (dit is het aantal items dat gereproduceerd wordt voordat er weer een pauze optreedt) significant samenhing met de mate van expertise. De 'runs' van de experts waren gemiddeld drie keer zo lang als de runs van de 'novieten'.

De inprentingsperiode bij dit onderzoek was nogal lang (twee minuten) en nogal intensief (voorgelezen en zelf meelezen). Daarom herhaalden Muzzin et al. (Muzzin, Norman, Feightner en Tugwell, 1983) dit onderzoek. In deze replicatie hanteerden ze behalve een bestuderingstijd van twee minuten ook een bestuderingstijd van 45 seconden per casus. Het casusmateriaal werd uitgebreid met een set rheumatologische casus, die op dezelfde wijze waren geconstrueerd. Proefpersonen waren beginnende derdejaars studenten, assistenten en specialisten in de cardiologie dan wel rheumatologie. Samenvoeging van deze resultaten met die uit het eerdere onderzoek leverde voor de hoeveelheid recall én significant effekt van mate van expertise op, namelijk bij de cardiorespiratoire problemen onder de korte bestuderingstijd. De totale recall van de subspecialisten was daarin lager dan van de beide andere groepen (beginnende derdejaars en assistenten). In plaats van het aantal items per run werd in dit geval de gemiddelde retrievaltijd per item berekend. Deze bleek af te nemen met een toenemende mate van expertise van de proefpersonen.

Patel en Frederiksen (1984) heranalyseerden de data van én typische en één atypische casus van het eerste experiment van Muzzin et al. (1982). Zij gebruikten hiervoor de recallprotocollen van zes studenten en zes artsen. Met behulp van een zeer gedetailleerde analysetechniek (die in hoofdstuk 2 nader wordt besproken) bepaalden zij het aantal proposities dat letterlijk werd gereproduceerd en het aantal proposities waarop bewerkingen waren uitgevoerd (inferenties genoemd). Verder splitsten $\mathrm{Pa}$ tel en Frederiksen deze proposities op in frame en non-frame proposities. Frame proposities zijn de echt medische elementen in de tekst. Nonframe proposities zijn elementen die ook zonder medische kennis goed kunnen worden geïnterpreteerd.

Deze analyses laten zien dat er weliswaar globaal gesproken geen verschil is in recall van een casus, maar dat bij een meer gedetailleerde analyse toch verschillen tussen experts en novieten te zien zijn. De artsen en de studenten reproduceren even veel van de typische casus. De artsen in- 
fereren echter veel meer terwijl de studenten meer letterlijk reproduceerden. Bij de atypische casus ligt dit effekt iets anders. Artsen en studenten infereren verhoudingsgewijs even veel, maar de artsen produceren minder letterlijke recall. Opgedeeld naar frame en non-frame proposities zijn er bij de typische casus weinig verschillen te bespeuren, maar het verschil tussen experts en novieten is bij de atypische casus zowel wat betreft de recall als de inferenties opmerkelijk. Artsen infereren meer dan studenten over de frame proposities, maar minder over de non-frame proposities, terwijl het omgekeerde geldt voor de letterlijke recall. Patel en Frederiksen laten op deze manier dus zien dat experts en novieten niet verschillen in uitgebreidheid van de probleemrepresentatie, maar dat de representatie van de experts meer verwerking en selektie van de informatie laat zien.

Coughlin en Patel (1986) vergeleken de recallprestaties van 16 tweedejaars studenten en 16 family practitioners. Zij gebruikten daarbij twee korte casus, waarvan de gegevens inde normale vorm of in een gerandomiseerde vorm werden aangeboden. Eén casus betrof een jonge man met acute bacteriële endocarditis, de andere een oudere vrouw met temporale arteritis. Voor beide casus hadden de proefpersonen drie minuten en 30 seconden leestijd tot hun beschikking. Ook Coughlin en Patel vonden geen verschil in de totale hoeveelheid recall van de casus tussen de studenten en de artsen. Verder bleek dat de vorm van de casus ook niet van invloed was op de recall. Wel bleek er sprake te zijn van een interaktie tussen expertise en relevantie van de onthouden items en van expertise met relevantie en responstype (letterlijke recall, gedeeltelijke recall en inferenties). Uit deze resultaten concluderen Coughlin en Patel dat er bij de experts meer sprake is van selektief encoderen. In een vervolganalyse (Coughlin en Patel, 1987) analyseerden de onderzoekers het type inferenties dat door de twee groepen proefpersonen werd gemaakt. $\mathrm{Zij}$ maakten daarbij onderscheid tussen low level inferenties (meest van lexicale aard) en high level inferenties (van meer causale aard). De resultaten suggereren dat de studenten meer low level inferenties maken dan de artsen.

Patel en Medley-Mark (1986) legden vier groepen proefpersonen van uiteenlopend expertiseniveau (aankomende studenten geneeskunde, tweedejaars studenten, vierdejaars studenten en internisten) twee casus voor. De ene betrof weer de jonge man met acute bacteriële endocarditis, de andere betrof een man van middelbare leeftijd met een gemetastaseerd maagcarcinoom. De resultaten laten een significante samenhang zien tussen mate van expertise en recall van de casus. De beginnende en de tweedejaars studenten herinnerden zich ongeveer even veel van de tekst. De vierdejaars studenten herinnerden zich veel meer van de casus, waarna de experts volgden die zich er weer minder van herinnerden, maar nog altijd meer dan de jongerejaars studenten. Dit effekt trad zowel op wanneer alle gegevens in de analyses werden betrokken, als bij de analyse van enkel de relevante gegevens. Bij de niet-relevante gegevens was geen sprake van een duidelijke piek bij de vierdejaars studenten. Verder bleek in dit onderzoek een toenemend expertiseniveau eerst gepaard te gaan met een 
toenemend aantal inferenties, maar bij een verder toenemend expertisenveau zette zich een daling in.

Met uitzondering van het onderzoek van Patel en Medley:Mark (1986) laten de onderzoekingen die gedaan zijn door Patel et al. (Patel en Frederiksen, 1984; Coughlin en Patel, 1986) geen verschillen zien in de hoeveelheid recall. Deze onderzoekers benadrukken dan ook dat een toenemende expertise gepaard gaat met een duidelijkere selektie van de relevante gegevens van de casus en, gezien de verschillen in inferentiepatronen, nemen zij aan dat ervaren artsen de gegevens op een andere manier verwerken.

Hassebrock, Bullemer en Johnson (1988) legden aan drie groepen proefpersonen twee casus met congenitale hartafwijkingen voor. Ook zij vonden geen verschillen in de hoeveelheid recall. Deze was onmiddellijk na de casuspresentatie gelijk bij derdejaars studenten, arts-assistenten kindergeneeskunde en kindercardiologen. Na eén week echter herinnerden de studenten zich nog even veel van de bestudeerde casus, terwijl de arts-assistenten en de cardiologen zich bijna niets meer van de casus konden herinneren met uitzondering van een aantal relevante gegevens.

Norman, Brooks en Allen (1987) gebruikten geen tekst, maar acht lijsten van 20 laboratoriumbepalingen die ofwel van echte patiënten afkomstig waren, ofwel ontleend waren aan een tabel van random getallen. Deze laboratoriumwaarden werden op twee wijzen aangeboden: op standaard laboratoriumformulieren of in random volgorde. Iedere proefpersoon kreeg acht casus aangeboden: uit iedere aanbiedingscombinatie twee. Recall volgde na een vrije bestuderingstijd. Norman et al. (1987) gebruikten proefpersonen van drie verschillende expertiseniveaus: vijf experts (specialisten in de cardiologie, nefrologie of de pulmonologie), zes gevorderden (tweedejaars medische studenten) en vijf novieten (onderzoeksassistenten). De hoeveelheid recall van de echte labdata vertoonde volgens de auteurs een bijna lineaire toename met toenemend niveau van expertise, onafhankelijk van de vorm waarin de waarden waren aangeboden. $B i j$ de random waarden was er geen verschil in recall tussen proefpersonen van verschillend expertiseniveau. Een bekende aanbiedingswijze kan echter helpen bij het representeren van de informatie. Verder bleek de bestuderingstijd samen te hangen met expertiseniveau. De studenten gebruikten meer tijd dan de anderen. Tenslotte bleek ook de samenhang in de recall toe te nemen met toenemend expertiseniveau.

Deze resultaten geven aan dat de uitgebreidheid van en de samenhang in de probleemrepresentatie varieert met het expertiseniveau van de proefpersonen en dat deze representatie met een toenemend expertiseniveau sneller tot stand komt. Dit effekt moet toegeschreven worden aan de kennis van de expert. Als deze kennis niet relevant is voor het voorgelegde probleem dan zijn er geen verschillen in probleemrepresentatie bespeurbaar.

Norman, Muzzin en Calva (z.j.) vergeleken de resultaten uit dit experiment met de resultaten die ze in een ander experiment hadden verkregen. In dat experiment (dat niet afzonderlijk is gepubliceerd) werden de 
prestaties van experts (vier nefrologen en pulmonologen) vergeleken met de recallprestaties van vier novieten (tweedejaars studenten). Deze proefpersonen kregen acht sets laboratoriumwaarden voorgelegd die afkomstig waren van patiënten met een respiratoir, een cardiologisch of een nefrologisch probleem, waaraan een korte beschrijving van de verschijnselen en symptomen van de patiënt was toegevoegd. Daarnaast kregen ze twee formulieren met daarop random waarden voorgelegd. Norman et al. (z.j.) vonden geen verschil in de hoeveelheid labwaarden, die door de twee groepen werden gereproduceerd. Er waren echter wel significante verschillen wanneer de hoeveelheid recall gedeeld werd door de hoeveellheid tijd die men aan de bestudering van de sets laboratoriumwaarden had besteed. Omgerekend naar standaardtijd hadden de experts van de echte laboratoriumwaarden twee keer zo veel onthouden als de novieten, terwijl er voor de random waarden geen verschillen waren. In dit onderzoek hangt de uitgebreidheid van de probleemrepresentatie dus niet samen met het expertiseniveau, wat echter wel geldt voor de snelheid waarmee die representatie tot stand is gekomen. Ook deze representatiesnelheid blijkt gemedieerd te worden door de aanwezigheid van toepasbare kennis. Als de gegeven informatie irrelevant is ten aanzien van de aanwezige kennis dan verdwijnt ook dat effekt.

Uit deze onderzoekingen komt geen consistent beeld naar voren van de relatie tussen mate van expertise en probleemrepresentatie. Soms is er een verschil gevonden in de zuivere hoeveelheid recall. Soms zijn die verschillen niet aanwezig, maar blijkt dat als de hoeveelheid gebruikte bestuderingstijd in acht wordt genomen de experts wel meer reproduceren dan novieten (en gevorderden). Ook blijkt dat het recallproces zelf anders verloopt bij experts. Er vindt een snellere retrieval plaats en er worden meer items in één adem genoemd. Verder wordt wel gevonden dat de manier waarop experts een casus reproduceren verschilt van de manier waarop novieten dat doen. Afhankelijk van de soort casus is er een verschil in de hoeveelheid inferenties en letterlijke recall die wordt gepleegd.

Al deze onderzoekingen wijzen erop dat er een relatie is tussen expertise en de representatie van medisch casus materiaal. De precieze uitkomsten zijn echter nogal wisselvallig, hetgeen er op zou wijzen dat de relatie tussen expertise en interne representatie medebeïnvloed wordt door andere variabelen. Zonder een nadere theoretische analyse en zonder een nauwkeurige beschouwing van het materiaal en de onderzoekscondities die in de besproken experimenten zijn gebruikt, kunnen hieruit echter geen conclusies worden getrokken. Voor het doel van dit hoofdstuk is het voldoende te constateren dat ook in het medisch domein een relatie tussen expertise en interne representatie, gemeten met een recallmethode, wordt gevonden. In Hoofdstuk 2 gaan we in op de details.

\section{Verschillen in kennisgebruik tussen novieten en experts}

Onderzoek naar de kennis, die geaktiveerd wordt door experts en novieten tijdens het oplossen van een medisch probleem is gedaan door Patel 
en haar medewerkers (Patel en Groen, 1985, 1986; Patel, Evans en Chawla, 1986; Kaufman en Patel, 1988). In deze onderzoekingen werd aan de proefpersonen steeds een korte casusbeschrijving voorgelegd. Vraag aan hen was de casus te diagnosticeren en het onderliggende proces in pathofysiologische termen te beschrijven. Patel en haar medewerkers beschouwen deze vraag om het onderliggende proces te beschrijuen als een stimulus die tot gevolg heeft dat de kennis die gebruikt werd om de casus te diagnosticeren, wordt gereaktiveerd.

Patel en Groen (1985) legden hun proefpersonen, beginnende medische studenten, studenten aan het einde van het tweede jaar en studenten die bijna het vierde jaar en daarmee hun medische studie hadden voltooid, een korte casusbeschrijving voor van een jonge man met acute bacteriële endocarditis. De patiënt heeft hoge koorts, koude rillingen, last van kortademigheid bij inspanning en meldt dat hij de dag tevoren een kortdurende visusdaling heeft gehad. Lichamelijk onderzoek toont aan dat er sprake is van een licht geruis ter hoogte van de aortaklep en er worden tekenen van venapunkties gevonden. Verder worden er bij labonderzoek ery's in de urine gevonden. Opdracht aan de proefpersonen was deze casus te bestuderen, te diagnosticeren en te beschrijven hoe de in de casus voorkomende verschijnselen met elkaar in verband gebracht kunnen worden. Slechts één bijna afgestudeerde student kwam tot de juiste diagnose, alle andere vierdejaars hadden een gedeeltelijk goede diagnose, terwijl de eerstejaars studenten geen van allen tot een juiste of gedeeltelijk juiste diagnose kwamen. De helft van de tweedejaars studenten had een gedeeltelijk juiste, de andere helft had een onjuiste diagnose. In een eerder onderzoek (Patel en Groen, 1986) kwam de helft van de cardiologen tot een volledig juiste diagnose en de andere helft had een gedeeltelijk juiste diagnose.

Uit hun beschrijvingen van het pathofysiologische proces, de pathofysiologische protocollen, blijkt dat de studenten geen relatie leggen tussen de verschillende deelprocessen die zij in deze casus herkennen (infektie, aorta-insufficiëntie en embolieën). Welke deelprocessen herkend worden, hangt overigens samen met het expertiseniveau van de proefpersonen. Ongeveer de helft van de eerstejaars ziet dat er sprake is van een infektieus proces; de ander componenten komen daar in de volgende jaren bij. Verder valt op dat de pathofysiologische protocollen van de studenten die aan dit onderzoek deelnamen veel meer pathofysiologische concepten bevatten dan die van de artsen.

In het onderzoek van Patel, Evans en Chawla (1986) met proefpersonen met vergelijkbare kwalifikaties en met dezelfde casus, werden deze resultaten in grote lijnen gerepliceerd. Naarmate de studenten verder waren gevorderd met hun opleiding waren ze beter in staat de verschijnselen in de casus als één samenhangend geheel te beschrijven en vertoonde hun pathofysiologisch protocol een grotere coherentie. Dit ging samen met een betere diagnostiek.

In het onderzoek van Kaufman en Patel (1988) werd, in tegenstelling tot de vorige onderzoekingen, met een echte patiënt gewerkt. Deze patiënt 
leed aan Grave's thyreotoxicose. Deze aandoening ging bij deze patiënt gepaard met tijdelijke verlammingen ten gevolge van hypokaliëmie. De proefpersonen waren vier endocrinologen, vijf assistenten in opleiding en vijf studenten in het laatste jaar van de basisopleiding. Zij namen bij de patiënt een anamnese af en deden een lichamelijk onderzoek. De rest van de onderzoeksopzet was vergelijkbaar met het onderzoek van Patel, Evans en Chawla. De proefpersonen werd gevraagd een diagnose te geven en de onderliggende pathofysiologie te beschrijven. De verklaringen van de experts vormden accurate en coherente causale modellen voor de gestelde diagnose (die in drie van de vier gevallen volledig juist was). Drie van de vijf gevorderden kwamen ook tot een juiste diagnose. De andere twee merkten de verlammingen en de hypokaliëmie niet op. Hun pathofysiologische protocollen waren gedetailleerder dan die van de experts en ze bevatten meer pathofysiologische concepten. Bovendien bevatten hun protocollen een aantal onjuistheden. De novieten kwamen geen van allen tot een volledig juiste diagnose. Vier van de vijf kwamen tot een gedeeltelijk juiste diagnose. Hun pathofysiologische beschrijvingen van die diagnosen bevatten echter veel onjuistheden en onvolkomenheden waarbij in een aantal gevallen sprake was van misconcepties.

De resultaten van de onderzoekingen van Patel en haar medewerkers laten zien dat er een duidelijke relatie is tussen de uitkomst van een probleemoplossingsproces en de kennis die de proefpersoon blijkens de pathofysiologische protocollen geaktiveerd heeft. Daarin zijn niet alleen grote inhoudelijke verschillen aan te wijzen, maar ook strukturele verschillen, met name in gedetailleerdheid. Of dit ook de kennis is die daadwerkelijk door de proefpersonen gebruikt is bij het oplossen van het probleem, is niet helemaal duidelijk .

Een onderzoek van Lesgold, Feltovich, Glaser en Wang (1981) beoogde eveneens de relatie tussen probleemrepresentatie en geaktiveerde kennis te onderzoeken. Ook in dit onderzoek wordt nagegaan wat de relatie is tussen de uitkomst van het diagnostisch proces en kenmerken van de toegepaste kennis. De onderzoekers vroegen novieten (eerstejaars en tweedejaars assistenten in opleiding), intermediates (derdejaars en vierdejaars assistenten in opleiding) en experts (geregistreerde specialisten) in de radiologie een aantal Röntgen-opnamen van de thorax te beschrijven en ze te diagnosticeren. De beschrijving van zo'n thoraxfoto kunnen we beschouwen als een on-line methode om de interne representatie van de proefpersoon te onderzoeken.

Lesgold et al. (1981) vonden duidelijke verschillen in de termen waarin men de thoraxfoto's beschreef en de strukturen waaraan men aandacht besteedde. De experts en de gevorderden beschreven de foto vooral in termen die te maken hebben met de anatomische lokalisatie en de veronderstelde aandoening. De novieten daarentegen gebruikten vaak termen die veel globaler van aard waren. Hierbij viel vooral op dat de mogelijke aandoening vaak helemaal niet werd genoemd, terwijl ook de anatomische strukturen in heel vage bewoordingen werden aangeduid. 
Bij de novieten kwamen Lesgold et al. (1981) zelfs aanduidingen tegen als 'lichte plek' en 'rechtsboven op de foto'. Deze verschillen in probleemrepresentatie gingen gepaard met verschillen in het aantal juiste diagnosen. De mate van juistheid van de diagnose bleek een U-vormig verband te vertonen met opleidings- en ervaringsniveau: de gevorderde proefpersonen deden het duidelijk slechter dan de novieten en de experts.

Om de kennis van de proefpersonen verder te onderzoeken, vroegen Lesgold et al. hun proefpersonen de anatomische strukturen bij een deel van de Röntgen-opnamen in te tekenen. Hierbij kwamen bij de novieten en de gevorderden allerlei anatomische mispercepties aan het licht. Bovendien bleek dat dezelfde proefpersonen vaak niet in staat waren om anatomische strukturen van elkaar te onderscheiden als die elkaar bij een Röntgen-opname (gedeeltelijk) overdekten. Fouten in de diagnostiek konden veelal op één van deze effekten worden teruggevoerd.

Om na te gaan hoe expertiseniveau en de struktuur van toegepaste kennis met elkaar samenhangen, deden Feltovich, Johnson, Moller en Swanson (1984) een onderzoek bij 12 proefpersonen die verschilden in mate van expertise in de kindercardiologie: vier kindercardiologen, vier assistenten algemene kindergeneeskunde en vier studenten die net een theoretische en praktische cursus van zes weken over dit onderwerp hadden doorlopen. Feltovich et al. (1984) legden deze proefpersonen vier statussen voor, compleet met Röntgen-opname van de thorax en een ECG. De opdracht aan de proefpersonen was de gegevens uit deze casus hardop voor te lezen en alles wat ze dachten bij het diagnosticeren van de casus hardop uit te spreken. De keuze van de casus en de analysetechniek waren erop gericht na te gaan welk cluster van aandoeningen de proefpersonen aktiveerden en op basis van welke gegevens zij vervolgens hun keuze bepaalden. Om dit te onderzoeken vergeleken zij de oplossingsweg van de proefpersoon met een ideale oplossingsweg.

De resultaten laten zien dat de kennis van de studenten nog sterk de sporen vertoonde van het gebruikte leerboek. Ze hanteren dezelfde clusters en dezelfde prototypische kenmerken van een ziektebeeld als in het leerboek worden beschreven. Met toenemende expertise nemen Feltovich et al. (1984) een toenemende verrijking waar in de kennis over een ziektebeeld: het aantal symptomen en verschijnselen dat leidt tot aktivatie van een bepaalde hypothese neemt toe en er wordt kennis toegevoegd over de pathofysiologie van het ziekteproces. Verder valt uit hun resultaten af te leiden dat de kennis realistischer wordt, in die zin dat meer recht gedaan wordt aan de natuurlijke variabiliteit in ziektebeelden. En de struktuur van de kennis verandert in die zin dat de onderlinge relaties tussen ziektebeelden veranderen. Bij de studenten is er sprake van een hiërarchische kennisstruktuur, die overeenkomt met de struktuur die in het leerboek wordt aangeboden (b.v. congenitale hartafwijkingen vallen uiteen in cyanotische en niet-cyanotische hartafwijkingen). Feltovich et al. constateren dat deze hiërarchie bij experts doorbroken is. Er zijn dwarsverbindingen aangelegd tussen ziektebeelden met een gelijke fysiologische struktuur en een 
gelijk klinisch beeld (in bovenstaande hièrarchie komen bijvoorbeeld in beide clusters hartafwijkingen voor waarin sprake is van een toegenomen bloedstroom in de rechterkant van het hart (disease with increased blood flow right side)). Deze verschillen in kennis en kennisstruktuur kwamen alle tot uiting in de diagnose en in de hypothesen die werden overwogen.

De resultaten van Feltovich et al. worden ondersteund door het werk van Bordage en Zacks (1984) die vonden dat de kenniscategorieën van artsen uitgebreider zijn dan die van studenten. Verder bleken er bij de artsen meer overlappingen tussen de categorieën te bestaan en waren er ook meer verbindingen tussen de eenheden binnen de categorieën, zodat de zoekprocessen sneller verlopen. Hun resultaten geven aan dat de kennis van de studenten meer hiërarchisch van aard is, terwijl de kennis van de artsen allerlei verbindingen bevat die deze hiërarchie doorbreken.

Verschil in toegankelijkheid van de kennis bij experts en novieten wordt gesuggereerd door het werk van Grant en Marsden (1987), die laten zien dat het aantal verschijnselen en symptomen van een patiënt, die aanleiding geven tot een bepaalde hypothese toeneemt met een stijgend expertiseniveau van de proefpersonen, een resultaat dat ook gevonden werd door Joseph en Patel (1987).

De onderzoekingen van Patel et al., Lesgold et al., Feltovich et al., Bordage en Zacks en Grant en Marsden bevestigen dat er verschillen zijn in de kennis die experts, gevorderden en novieten toepassen bij het oplossen van een probleem. De kennis versehilt in de juistheid en de precisie. Beide nemen toe met een toenemend expertiseniveau. De samenhang in de toegepaste kennis blijkt toe te nemen, terwijl de pathofysiologische gedetailleerdheid lijkt af te nemen. De doelgerichtheid van de kennis zou daarentegen juist toenemen. Ook de toegankelijkheid van de kennis verbetert met een toenemend expertiseniveau. De hiërarchische struktuur tenslotte die overeenstemt met hetgeen uit de leerboeken wordt geleerd, wordt onder invloed van de ervaring doorbroken. Deze verschillen in toegepaste kennis gaan samen met verschillen in de juistheid van de gestelde diagnose. Patel et al. en Feltovich et al, vinden dat de diagnose adequater wordt met een toenemende mate van expertise. Lesgold et al. vinden echter dat er eerst sprake is van een verslechtering van de diagnostiek. Daarna, bij een verder toenemende ervaring, verbeteren de diagnostische prestaties weer. Dit laatste onderzoek is het enige onderzoek dat niet alleen een on-line methode gebruikt om de toegepaste kennis te bestuderen. Er werden ook een aantal open vragen gebruikt, waarmee misconcepties en mispercepties opgespoord, fouten in de kennis en in de toepassing van de kennis werden opgespoord. Fouten in de diagnostiek konden veelal op deze fouten in de kennis worden teruggevoerd. 


\section{EEN INFORMATIEVERWERKINGSMODEL VOOR PROBLEEMOPLOSSEN IN HET MEDISCH DOMEIN}

In deze paragraaf zullen we proberen de resultaten van onderzoek naar expertise en probleemoplossen in het medisch domein te relateren aan het informatieverwerkingsmodel dat eerder beschreven is. Daartoe zullen eerst de resultaten die in de vorige twee paragrafen zijn beschreven, kort worden samengevat. Vervolgens zullen we proberen deze resultaten een plaats te geven in het informatieverwerkings- en kennisverwervingsmodel. Tenslotte zullen we ingaan op de vraag hoe goed de gevonden resultaten aansluiten bij dat model en welke vragen het oproept.

De resultaten van het onderzoek naar de relatie tussen het oplossen van problemen in het medisch domein en toenemende expertise kunnen als volgt worden samengevat.

a) De probleemrepresentaties van experts, gevorderden en beginnelingen verschillen van elkaar op een aantal punten. Vaak bleek de uitgebreidheid van de probleemrepresentatie te variëren met het expertiseniveau van de proefpersonen, terwijl de probleemrepresentatie van de experts in minder tijd tot stand kwam.

b) Deze uitgebreidere probleemrepresentatie vertoont bovendien een grotere samenhang, die toegeschreven kan worden aan de toepassing van relevante kennis.

c) Het onderzoek naar de kennis, die toegepast wordt door personen van verschillend expertiseniveau, toont aan dat er duidelijke inhoudelijke en strukturele verschillen zijn tussen proefpersonen van verschillend expertiseniveau. De kennis verschilt in juistheid, in precisie, in samenhang en in doelgerichtheid. In deze aspekten zien we steeds een toename. Verder raakt de kennis steeds meer toegesneden op de praktijk: ze doet steeds meer recht aan de natuurlijke variaties die er mogelijk zijn in de manier waarop ziekten tot uitdrukking komen en kunnen verlopen. Ook bleek de kennis steeds rijker te worden. Het aantal gegevens waardoor een bepaalde hypothese kan worden geaktiveerd, neemt toe. Maar op het gebied van de pathofysiologische kennis bestaan tegenstrijdige bevindingen: de resultaten van de groep van Patel laten zien dat er sprake is van een afname, terwijl Feltovich et al, laten zien dat er juist pathofysiologische kennis wordt toegevoegd. Tenslotte bleek dat de struktuur van de kennis met een toenemende mate van expertise steeds minder overeen komt met de struktuur die we in het leerboek vinden.

d) Het onderzoek naar de struktuur van de kennis bevestigt een aantal van deze resultaten. Experts verschillen van novieten in het aantal onderlinge verbindingen van de kenniselementen, in aard en omvang van de categorieën waarin die elementen zijn samengevoegd, en in rijkheid. van de kennis, resulterend in verschillen in toegankelijkheid. 
e) Deze verschillen in kenmerken van de toegepaste kennis en van de probleemrepresentatie leiden tenslotte tot verschillen in uitkomst van het probleemoplossingsproces.

Hoe zijn nu deze resultaten in te passen in het model van informatieverwerking en kennisverwerving dat eerder is geschetst?. Dit model kwam in het kort hierop neer. Binnenkomende informatie wordt in het korte duur geheugen bewerkt ${ }^{14}$. De informatie zelf plus de resultaten van die verwerking vormen de interne representatie van die informatie. $\mathrm{Be}$ werking van de informatie vindt plaats met behulp van kennis. Deze kennis verandert met toenemend expertiseniveau. Eerst wordt in de accumulatiefase een uitgebreid bestand van declaratieve en procedurele kennis opgebouwd. Daarna wordt deze kennis getuned: door koppeling aan de toepassingscondities wordt kennis gespecialiseerd, zoekpaden worden verkort en de toepassing van de kennis wordt in toenemende mate geautomatiseerd.

Wanneer we nu deze theoretische uitgangspunten en de gevonden resultaten met elkaar vergelijken valt een aantal zaken op. Ten eerste sluiten het model en de resultaten die betrekking hebben op de relatie tussen interne representatie en het niveau van expertise perfekt op elkaar aan. De beschikbaarheid van relevante kennis speelt in de constructie van de interne representatie een doorslaggevende rol. Ook de veranderingen in de kennis die gevonden werden, passen - zij het ten dele - in het beschreven model. De expertkennis bleek door meer gegevens geaktiveerd te kunnen worden dan de kennis van beginners. De kennis van de experts is dus sterker gekoppeld aan de toepassingscondities. De kennis van experts bleek ook duidelijk meer genuanceerd te zijn, zoals het model veronderstelt. Afstemmingsprocessen zijn moeilijk waar te nemen in de gepresenteerde resultaten. Het resultaat dat we vonden bij Patel en haar medewerkers (Patel en Groen, 1985, 1986; Patel, Evans en Chawla, 1986; Kaufman en Patel, 1988), namelijk dat de toegepaste pathofysiologische kennis afnam, kan geïnterpreteerd worden als een blijk van verkorting van de zoekpaden, van afstemming dus. Maar dit resultaat wordt weersproken door de bevindingen van Feltovich et al.(1984). Een ander resultaat dat moeilijk in het gepresenteerde model ingepast kan worden, betreft de herstrukturering van de kennishiërarchie. Deze hiërarchie wordt bij een toenemend expertiseniveau doorbroken doordat er steeds meer verbindingen ontstaan tussen elementen uit verschillende klassen. Dit resultaat plaatst ons voor een probleem, omdat het model geen voorspellingen doet over dit type veranderingen.

Kort gezegd komt het er dus op neer, dat de besproken resultaten goed passen in het informatieverwerkings en kennisverwervingsmodel dat

\footnotetext{
${ }^{14}$ In dit proefschrift zullen we geen onderzoek doen naar de deelprocessen die bij probleemoplossen zijn te onderscheiden. Dit deel van het model is daarom niet nader uitgewerkt.
} 
we hebben beschreven. De resultaten laten ook zien dat het model niet volledig is waar het de struktuurveranderingen in de kennis betreft.

\section{EEN SCHETS VAN HET INDIT PROEFSCHRIFT TE PRESENTEREN ONDERZOEK}

Doel van dit proefschrift is te komen tot een theorie over de ontwikkeling van de medische kennis tijdens de studie en daarna in de praktijk. De inventarisatie van onderzoek op het gebied van medisch probleemoplossen, die in dit hoofdstuk heeft plaatsgevonden doet vooralsnog een aantal vragen rijzen. In de drie volgende hoofdstukken van dit proefschrift zullen deze successievelijk aan de orde worden gesteld. Deze hoofdstukken vormen als het ware een drieluik.

In Hoofdstuk 2 stellen we de samenhang tussen expertiseniveau en de interne representatie van informatie centraal. We onderwerpen daartoe de onderzoekingen die al in Hoofdstuk $\mathbb{1}$ aan de orde zijn gesteld aan een nadere analyse, zowel wat betreft de theoretische achtergrond als wat betreft de onderzoeksopzet en resultaten. De theorie die hieruit voortvloeit, wordt vervolgens getoetst in een eerste experiment waarbij gebruik wordt gemaakt van een recallmethode. Verschillen in interne representatie die samenhangen met het expertiseniveau van de proefpersoon leveren een eerste bouwsteen voor de te ontwikkelen theorie.

In Hoofdstuk 3 wordt vervolgens de relatie tussen interne representatie en de aard van de toegepaste kennis aan de orde gesteld. Bepaalde verschijnselen, die steeds weer gevonden worden in het onderzoek naar de interne representatie van informatie van personen van verschillend expertiseniveau, worden daarin verklaard met behulp van struktuurkenmerken van de kennis die gebruikt wordt bij het bestuderen van de informatie. Deze kennisstrukturen veranderen tijdens de ontwikkeling tot expert. Hierdoor wordt het voor de expert mogelijk een casus zeer snel te representeren. Studenten daarentegen moeten nog een hele redenering opzetten om alle relevante elementen uit de casusbeschrijving met elkaar te verbinden. In dit hoofdstuk wordt een experiment gepresenteerd, dat deze verklaring onderzoekt. Hierin wordt gebruik gemaakt van zeer korte bestuderingstijden waardoor redeneren wordt bemoeilijkt.

In Hoofdstuk 4 gaan we dieper in op de struktuur van medische kennis en op de ontwikkeling daarvan tijjens de studie en daarna in de praktijk. We zullen daartoe twee experimenten bespreken. In het eerste experiment wordt een zeer gedetailleerde analyse gedaan van de kennis die vier proefpersonen van verschillend expertiseniveau toepassen bij het oplossen van een medisch probleem. In het laatste experiment wordt weer de kennis onderzocht die de proefpersonen toepassen tijdens het diagnosticeren van een casus, maar vervolgens wordt nagegaan wat ze feitelijk over het betreffende onderwerp weten. Vergelijking van wat men feitelijk weet en wat men blijkt te gebruiken bij het oplossen van medische problemen in verschillende stadia van het ontwikkelingsproces levert inzich- 
ten op in de struktuur van de kennis tijdens verschillende stadia van het ontwikkelingsproces en levert bovendien een aanzet tot theorievorming over de aard van het ontwikkelingsproces.

Het proefschrift besluit met een hoofdstuk waarin de inzichten die in de vorige hoofdstukken zijn ontstaan, worden samengevoegd tot een theorie over de ontwikkeling die iemands medische kennis doormaakt ten gevolge van bestudering van theorie en toepassing van het geleerde in de praktijk. Dit laatste hoofdstuk eindigt met een bespreking van een aantal consequenties van deze inzichten voor het medisch onderwijs. 


\section{HOOFDSTUK 2}

\section{POST HOC ONDERZOEK VAN DE PROBLEEMREPRESENTATIE: RECALL STUDIES ${ }^{1}$}

\section{INLEIDING}

In Hoofdstuk 1 is geconstateerd dat recallstudies naar de interne representatie van medische problemen door proefpersonen van verschillende expertiseniveaus geen eenduidige resultaten hebben opgeleverd. In één onderzoek was er sprake van een rechtlijnig verband tussen mate van expertise en hoeveelheid recall (Norman, Brooks en Allen, 1987). In de andere beschreven onderzoekingen werd dit verband niet gevonden. In het merendeel van de onderzoekingen werd geen relatie gevonden tussen mate van expertise en hoeveelheid recall (Boshuizen en Claessen, 1981; Claessen en Boshuizen, 1985; Coughlin en Patel, 1986; Muzzin, Norman, Jacoby, Feightner, Tugwell en Guyatt, 1982; Norman, Muzzin en Calva, z.j.; Norman, Jacoby, Feightner en Campbell, 1979). In een tweetal andere onderzoekingen werd wel een relatie gevonden tussen expertiseniveau en hoeveelheid recall, maar deze relatie was niet rechtlijnig (Patel en Medley-Mark, 1986; Muzzin, Norman, Feightner en Tugwell,

${ }^{1}$ Delen van dit onderzoek zijn eerder gepubliceerd in Claessen, H.F.A. en Boshuizen, H.P.A. (1985), Recall of medical information by students and doctors. Medical Education, 19, 61-67. 
1983). De meest ervaren groep onthield in deze twee studies minder van de casus dan een minder ervaren groep. Hassebrock, Bullemer en Johnson (1988) tenslotte vonden bij een eerste recallmeting geen verschillen tussen experts en novieten; na éen week traden er echter wel significante verschillen op. De artsen konden zich nu minder van de voorgelegde casuistiek herinneren dan de studenten.

Deze resultaten staan deels op gespannen voet met de resultaten die in andere domeinen werden gevonden. Zo vonden Spilich, Vesonder, Chiesi en Voss (1979) dat baseballexperts meer onthielden van een tekst over dat onderwerp dan mensen die daar vrijwel niets vanaf wisten. Ook Schmidt, De Grave, De Volder, Moust en Patel (1989) vonden bij een studietekst over het onderwerp 'osmose en diffusie' dat experts op dat gebied veel meer van de tekst onthielden dan novieten. Terwijl McKeithen, Reitman, Rueter en Hirtle (1981) en Shneiderman (1976) vonden dat ervaren programmeurs veel meer van een computerprogramma onthielden dan beginners. Daarnaast is door onderzoek van onder anderen Bransford en Johnson (1972) en Dooling en Lachman (1971) aangetoond dat het al dan niet geaktiveerd zijn van voorkennis verantwoordelijk moet zijn voor deze resultaten. Terwijl ook in allerlei niet-verbale domeinen zoals voetbaluitslagen (Morris, Gruneberg, Sykes en Merrick, 1981), go (Reitman, 1976), telegrafie (Bryan en Harter, 1899), hoofdrekenen (Hunter, 1962; Müller, 1911) en schaken (De Groot, 1946, 1965; Jongman, 1968; Chase en Simon, 1973a, 1973b) experts steeds meer informatie onthielden dan beginnelingen of minder ervaren personen op dat gebied.

Er kunnen verschillende mogelijke oorzaken zijn voor de afwezigheid van eenduidige resultaten. Er kleven natuurlijk methodologische tekortkomingen aan allerlei experimenten. De definities van 'experts' en 'novieten', die werden gehanteerd, vertoonden weinig overeenstemming. Claessen en Boshuizen (1985) vergeleken studenten van verschillende jaargroepen met elkaar, terwijl Norman, Brooks en Allen (1987) leken, studenten en specialisten met elkaar vergeleken. Verder blijken er grote verschillen in procedures te bestaan. Muzzin, Norman, Feightner en Tugwell (1983) lieten de proefpersonen bandjes met de casusteksten horen. Coughlin en Patel (1986) gebruikten teksten die de proefpersonen voor zichzelf moesten lezen. Claessen en Boshuizen (1985) boden de casusinformatie op kaartjes aan. De situatie wordt verder gecompliceerd door het ontbreken van expliciete meettheorieèn, die de relatie tussen theoretische constructen en data definiëren.

In dit hoofdstuk zullen we daarom trachten eerst na te gaan welke meettheoretische uitgangspunten ten grondslag lijken te liggen aan het bestaande onderzoek. Op grond van die analyse zullen we een poging wagen een meettheorie te formuleren, die precieze voorspellingen mogelijk maakt met betrekking tot relevante kenmerken van de recall. Deze theorie zal worden getoetst aan de resultaten van de 11 recallstudies, die reeds in Hoofdstuk 1 aan de orde zijn gesteld. Tenslotte zullen we de re- 
sultaten presenteren van een recallstudie die gebaseerd is op voornoemde meettheoretische uitgangspunten.

\section{Meettheoretische veronderstellingen}

Opmerkelijk is dat veel auteurs in het medisch domein, die onderzoek rapporteren over de relatie tussen mate van expertise en hoeveelheid recall, zich niet uitlaten over de oorsprong van die relatie. Algemeen wordt aangenomen dat de kennis die experts tot hun beschikking hebben, helpt bij het onthouden van nieuwe informatie. De vraag echter waarom dat het geval zou zijn en hoe het gebruik van kennis zou doorwerken in kenmerken van de recall van een medische casus komt vrijwel niet aan de orde.

De onderzoeksgroep verbonden aan McMaster University in Hamilton, Canada, (Norman, Jacoby, Feightner en Campbell, 1979) gaf een zeer pragmatische uitwerking van de veronderstelde samenhang tussen recall en expertise. De onderzoekers hoopten hiermee een methode gevonden te hebben die sensitief is voor verschillen in kennis en kennisstruktuur bij een hoog niveau van expertise. Met de normale kennistoetsen kunnen bij deze groepen vaak geen verschillen worden aangetoond en soms werken ze zelfs ten nadele van de meer ervarenen. In Maastricht probeerden Claessen en Boshuizen (1985) met deze methode verschillen in kennisstruktuur aan te tonen tussen studenten die aan een fakulteit met een traditioneel curriculum studeren en studenten van een faculteit met een. probleem-gestuurd curriculum. De meettheoretische fundering van hun onderzoek bestaat uit twee principes: a) Bestaande kennis en eerdere ervaringen met patiënten met hetzelfde beeld verlenen samenhang en coherentie aan de interne representatie van een medische casus. Een coherentere representatie zou beter kunnen worden gereproduceerd. $\mathrm{Zij}$ nemen aan dat het belang van een dergelijke samenhangende representatie toeneemt naar mate de hoeveelheid te verwerken informatie toeneemt. b) De manier waarop informatie is opgeslagen in het geheugen, is van invloed op de manier waarop die informatie wordt gereproduceerd en daarmee op de hoeveelheid en de samenhang van de recall. Bij deze benadering van recallstudies wordt het recallprotocol dus opgevat als een weergave van de interne representatie van de informatie, die bovendien iets zegt over de struktuur van de kennis in het lange duur geheugen (Ericsson en Simon, 1984, p. 185). Helaas maken de auteurs niet duidelijk hoe uit de recallgegevens de struktuur van de kennis moet worden afgeleid.

De groep onderzoekers aan McGill University in Montreal, Canada, koos een andere theoretische invalshoek: Patel en Frederiksen (1984) baseren zich op de 'discourse comprehension' theorie (Kintsch, 1974; Frederiksen, 1975). Volgens Patel en Frederiksen komt de interne representatie van een tekst tot stand in een integratief proces van bottom up tekstinterpretatie en top down kennistoepassing. In een recent artikel (Groen en Patel, in druk) werken zij dit uit op een manier analoog aan het model van Van Dijk en Kintsch (1983). Volgens Van Dijk en Kintsch wordt 
discourse (een mondeling of schriftelijk weergegeven tekst) op meerdere manieren in het episodisch geheugen gerepresenteerd. Er wordt een 'textbase' geconstrueerd die overeen komt met de semantische representatie van de input in het episodisch geheugen. De textbase bevat onder andere de propositionele struktuur van de tekst, evenals de oppervlaktekenmerken en de macrostruktuur van de tekst. Een textbase moet een zekere mate van samenhang vertonen. Deze eis betreft niet alleen het lokale niveau van de individuele elementen die aan elkaar gerelateerd moeten worden. Het betreft ook het meer globale niveau van de tekst. Zonder deze coherentie is het vrijwel onmogelijk een begrip te krijgen van wat er in de tekst staat. Bij de constructie van de textbase wordt gebruik gemaakt van kennis over teksttypen en hun opbouw: sprookjes, kranteberichten, wetenschappelijke verslagen en patiëntbeschrijvingen hebben alle hun eigen specifieke struktuur. Tegelijkertijd met de textbase wordt het 'situatiemodel' gecreèerd met behulp van de kennis, waarover de lezer of luisteraar beschikt en op basis van de ervaringen, die de persoon heeft. Dit situatiemodel wordt ook in het episodisch geheugen gerepresenteerd. Het situatiemodel vormt de cognitieve representatie van de tekst. Deze cognitieve representatie heeft geen uniforme kenmerken, is geheel afhankelijk van het onderwerp en kan meer of minder abstract zijn. Bij romanteksten of kranteberichten bevat het situatiemodel de cognitieve representatie van de gebeurtenissen, de akties en de personen, en in het algemeen de situatie, waarover die tekst gaat. Bij een medische casusbeschrijving zal het eerder de cognitieve representatie omvatten van de persoon van de patiënt, diens medische voorgeschiedenis en de huidige bevindingen: dat wil zeggen, de interpretaties ervan en de elaboraties erop. Het situatiemodel bevat naast de gerepresenteerde aktuele informatie ook algemene kennis over vergelijkbare situaties en vroegere ervaringen, in tegenstelling tot de textbase die uitsluitend input informatie bevat. Van Dijk en Kintsch veronderstellen dat de zich ontwikkelende textbase tijdens de constructiefase voortdurend vergeleken wordt met het simultaan daarmee opgebouwde situatiemodel. Pas wanneer er een zekere mate van overeenkomst is tussen textbase en situatiemodel en wanneer de bereikte lokale en globale coherentie voldoende is, zal de lezer/toehoorder het idee hebben de input te begrijpen. Dit hele begripsproces staat onder controle van de wensen, eisen, doelen, plannen en belangstelling van de lezer of luisteraar. Deze bepalen aan welke elementen veel aandacht wordt besteed, aan welke elementen weinig en welke elementen helemaal worden overgeslagen.

Naar aanleiding van onderzoek van Kintsch en Greeno (1985) veronderstellen Groen en Patel (in druk) dat de textbase de onmiddellijke recall bepaalt; het situatiemodel daarentegen bepaalt de oplossing van een probleem dat in zo'n tekst wordt gepresenteerd. Van Dijk en Kintsch (1983) argumenteren echter zelf dat dit zeker niet altijd zo hoeft te zijn. Ik citeer hun argumenten uitvoerig: 
"There are some clear-cut demonstrations in the psychological literature that under certain conditions people remember the situation model but not the text representation. Usually this involves conditions in which the text representation is very difficult to construct, perhaps because many very simillar sentences are used, creating massive amounts of interference, so that the comprehender skips the text representation and concentrates entirely on the situation model, which typically is nice and simple (e.g., Bransford \& Franks, 1972; Potts, 1972, Barclay, 1973). Thus, it is easy to remember that "hawks are smarter than bears which are smarter than lions which are smarter than wolves" - but it is almost impossible to remember a bunch of comparative sentences with these arguments in various combinations. The only functions these sentences serve is to permit the listener to construct an appropriate situation model, but not a textbase (which would be an extremely impoverished one in any case).

An alternative way of showing that the situation model is remembered but not the textbase involves giving subjects sentence pairs in which there are minimal distinctions in the textbase (say a difference of a single preposition) but very large ones in the situation model (the single preposition makes the situations described very different ones). In this case, too, subjects confuse the sentences, but not the situations (Bransford, Barclay \& Franks, 1972, Garnham, 1981).

Conversely, there are situations where people remember the text but have no situation model at all, as when children are taught to chant Hebraic texts or the Koran without understanding what they are saying. Typically, however, long-term memory is poor in the absence of understanding; that is a situation model, as is demonstrated for instance in the well-known findings of Bransford and Johnson (1972). There are strong theoretical reasons why memory should be better for the situation model than for the textbase itself: Retrieval is most likely to occur if a memory episode is embedded within some larger structure which can serve as a retrieval system. Situation models, by their very nature, tend to be embedded in such systems and form a part of a larger model, whereas the textbase itself is more loosely associated with these structures, often via the corresponding model. In those cases, retrieval of the textbase would require the activation of the model, but not vice versa. This is, of course, not true in all cases, because it certainly is possible to retrieve a textbase via some textual cue directly, but this seems to be the exception rather than the rule. Furthermore, the textbase proper, once it has fulfilled its main purpose as a stepping stone toward the situation model, will rarely be reactivated, whereas the corresponding model, if the information it contains is of any importance at all to the indivi dual, may be subject to extensive use and updating $(\ldots)$. This retrieval practice will greatly strengthen the retrievability of the model (Hogan \& Kintsch, 1971) whereas the textbase proper experiences no such adyantage." (Van Dijk en Kintsch, 1983, pp 340-341).

Uit dit betoog van Van Dijk en Kintsch (1983) vloeit dus voort dat zowel kenmerken van de textbase als van het situatiemodel van invloed kunnen zijn op de recall. Hoe vollediger en coherenter de textbase hoe beter de recall van de tekst zal zijn. En aan de andere kant, hoe helderder en eenvoudiger het situatiemodel, hoe groter de invloed ervan op de recall. 
In dit proefschrift zullen we aansluiten bij de opvattingen van Van Dijk en Kintsch (1983) en deze nader uitwerken voor het representeren en onthouden van teksten die medische problemen beschrijven. De resulterende meettheorie moet niet alleen voorspellingen toestaan omtrent de omvang van de recall maar ook omtrent de snellheid van representeren en van clustering in de recall, variabelen waarop effekten van expertise gevonden werden in enkele van de recallstudies, die we in Hoofdstuk 1 bespraken, We nemen hier aan dat de constructie van de textbase voornamelijk een bottom up proces is. De constructie van het situatiemodel daarentegen, hetgeen bestaat uit het instantiëren van reeds aanwezige kennis, vindt in hoofdzaak plaats via top down verwerking. De geaktiveerde en steeds verder geinstantieerde kennis vormt als het ware een interpretatieen verwachtingsmodel voor nog komende informatie 2 .

We nemen aan dat er bij de constructie van de textbase weinig verschillen zullen zijn tussen gevorderden en experts in de geneeskunde. Leken en beginners in het terrein zullen echter nog geen volledige kennis hebben van de terminologie die in dat terrein wordt gehanteerd. Voor hen zal de constructie van de textbase dus problemen oproepen. Het verkrijgen van coherentie in een textbase wordt in belangrijke mate ondersteund door kennis van de tekststruktuur. In de medische wereld is het de gewoonte om de patiënt op een standaardwijze te beschrijven. Eerst een korte beschrijving van de persoon en omstandigheden van de patiënt, dan de klacht, de gegevens uit de anamnese, de onderzoeksgegevens en de laboratoriumgegevens en/of de gegevens uit verder aanvullend onderzoek. Ervaring met het patiëntpresentatieschema vereenvoudigt de constructie van de textbase. Een toenemende bekendheid met de terminologie en met de wijze waarop medische casus gewoonlijk worden gepresenteerd, leidt dus tot een grotere volledigheid en coherentie in de textbase. Het lijkt echter niet aannemelijk dat dit een lineair verband tussen mate van expertise en recall zal opleveren. Ouderejaars studenten zullen vrijwel even goed met deze zaken op de hoogte zijn als artsen. We verwachten daarom dat de curve die de relatie tussen expertiseniveau en recall beschrijft tot een asymptoot zal naderen.

Personen van verschillend expertiseniveau zullen vooral verschillen in domeinkennis. De kennis van experts is uitgebreider en kan sneller worden geaktiveerd. Experts zullen dus sneller en gemakkelijker een probleemmodel voor de gebruikte casus aktiveren of, wanneer dit niet gebruiksklaar aanwezig is, eventueel construeren. Hierdoor zal met toene-

${ }^{2}$ Van Dijk en Kintsch (1983) hanteren in hun boek steeds de term 'situatiemodel'. Deze term is niet goed van toepassing op de representatie van medische casusbeschrijvingen. Daarvoor wordt te veel de nadruk gelegd op de situatie waarin een beschreven gebeurtenis plaatsvindt. Elders (Kintsch en Greeno, 1985) wordt de term 'problem model' gebruikt. Gezien de funktie van het situatie- of het probleemmodel zou de term 'interpretatiemodel" onzes inziens de voorkeur hebben. Om de hoeveelheidl termen niet onnodig te vergroten, sluiten we ons hier aan bij Kintsch en Greeno. We zullen in het vervolg steeds spreken van "probleernmodel". 
mende expertise de top down component in de informatieverwerking een steeds sterker karakter krijgen, waardoor experts een casus sneller kunnen representeren. Experts kunnen informatie door de aard van hun probleemmodel beter integreren. Door deze integratie zal hun textbase meer conclusies bevatten die gebaseerd zijn op meerdere gegevens. Hierdoor zullen in hun recall ook meer van dergelijke conclusies worden gevonden.

Onze theoretische overwegingen zijn erop gericht niet alleen voorspellingen te kunnen doen over de hoeveelheid recall, maar ook over de samenhang in de recall en over de representatiesnelheid. We kunnen nu zeggen dat een toenemend expertiseniveau gepaard gaat met een probleemmodel dat sneller beschikbaar is en beter past bij de bestudeerde casus en met een volledigere en meer coherente textbase. Een coherentere textbase staat gelijk aan een beter samenhangende interne representatie en leidt dus tot een betere samenhang in de recall. Een sneller beschikbaar probleemmodel leidt tot een snellere verwerking van de casus. Textbase en probleemmodel resulteren beide in een uitgebreidere en beter geintegreerde interne representatie, hetgeen leidt tot een betere recall van de casus bij een toenemend expertiseniveau. We verwachten daarbij dat de relatie tussen expertise en textbase zal leiden tot een hoeveelheid recall, die een horizontale asymptoot nadert. Voor de relatie tussen expertiseniveau en probleemmodel hebben we geen begrenzing geformuleerd. We verwachten dan ook dat de hoeveelheid inferenties gelijkmatig zal stijgen met een toenemend expertiseniveau. Deze twee effekten tezamen doen verwachten dat er een positieve, lineaire samenhang is tussen expertiseniveau en recall van een casus.

Op grond van het voorafgaande kunnen we dus voorspellen dat een toenemend expertiseniveau gepaard gaat met een grotere hoeveelheid recall van een casusbeschrijving, tot een kortere bestuderingstijd, tot een stijgend aantal inferenties en tot een toenemende samenhang in de recall.

We zullen nu eerst de 11 recallstudies uit Hoofdstuk 1 analyseren om na te gaan in hoeverre ze de geformuleerde hypothesen ondersteunen en om na te gaan in hoeverre de tegenstrijdige resultaten die we al eerder signaleerden te wijten zijn aan verschillen in de gebruikte methode.

\section{Analyse van de recallstudies: onderzoeksopzet en resultaten}

De resultaten en de belangrijkste kenmerken van de onderzoekingen die in Hoofdstuk 1 zijn beschreven, zijn in Tabel 2.1 bij elkaar gezet. Deze resultaten kunnen betrekking hebben op de hoeveelheid recall van de bestudeerde casus, de bestuderingstijd, de hoeveellheid recall gecorrigeerd voor bestuderingstijd (recall/bestuderingstijd), de tijd benodigd voor de recall, de hoeveelheid recall gecorrigeerd voor de recalltijd (recall/recalltijd), en de clustering in de recall. In geen enkel onderzoek zijn al deze variabelen gemeten. Alleen de hoeveelheid recall is in alle studies onderzocht. Naast de onafhankelijke variabele 'niveau van expertise' komen diverse casusvarianten voor: typische of atypische casus, 


\begin{tabular}{|c|c|}
\hline 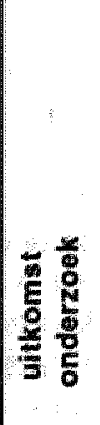 & 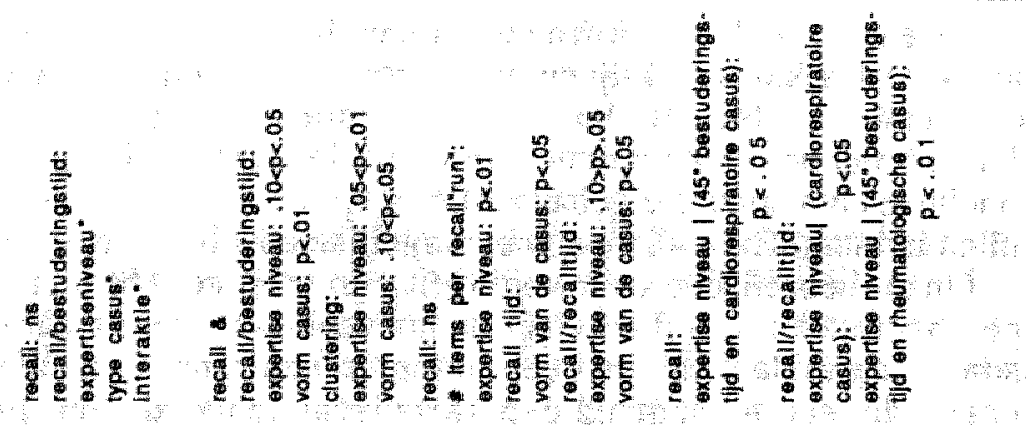 \\
\hline 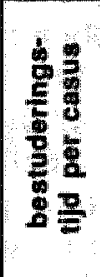 & 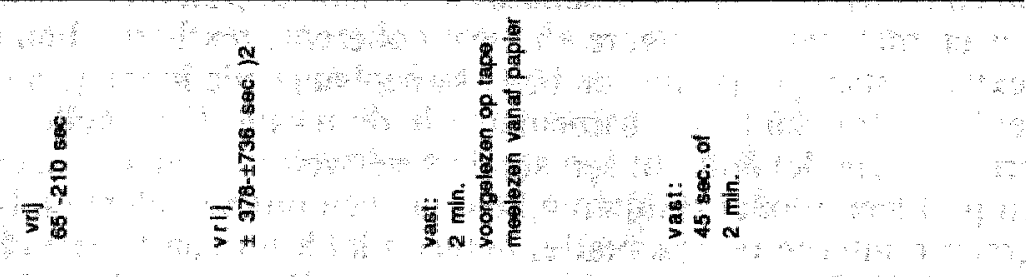 \\
\hline 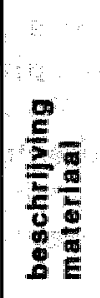 & 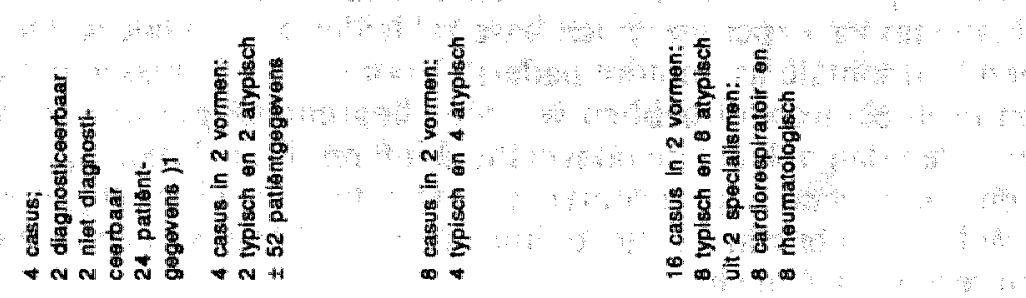 \\
\hline 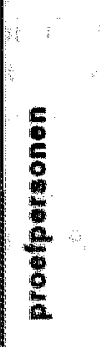 & 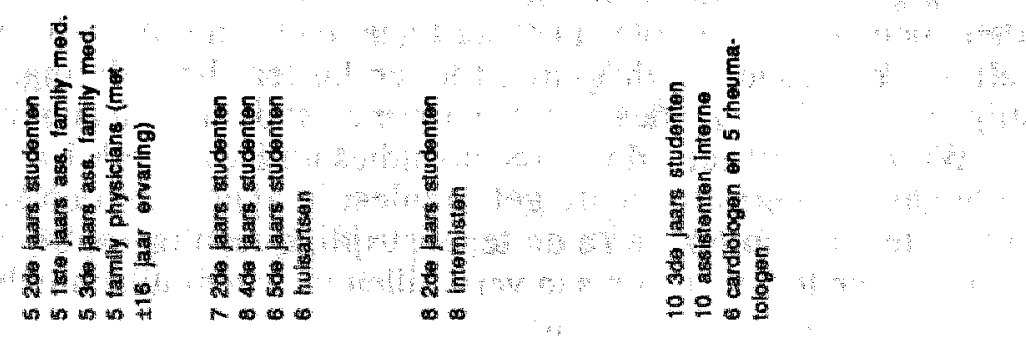 \\
\hline 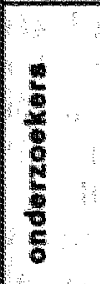 & 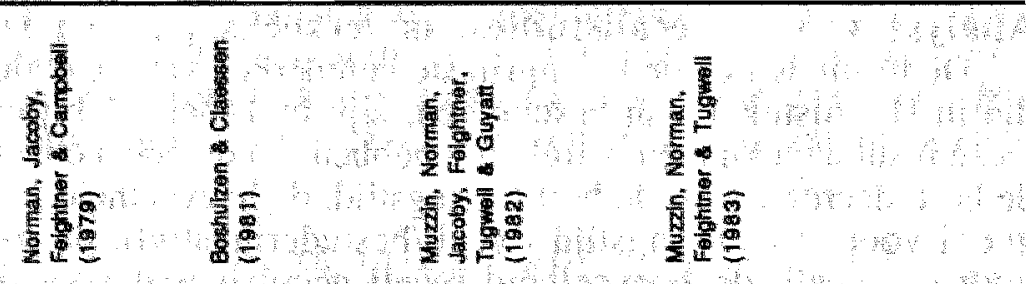 \\
\hline
\end{tabular}

Tabel 2.1 Elf recallstudies uit het medisch domein met elkaar vergeleken.

1. Norman et al. melden zelf 48 'bits of informtion'. Hierbij wortdt een gegeven als 'pols: $80 / \mathrm{min}$ ' als 2 bits geteld.

2. Laagste en hoogste groepsgemiddelden.

3. Einde tweedejaars en begin derdejaars. 

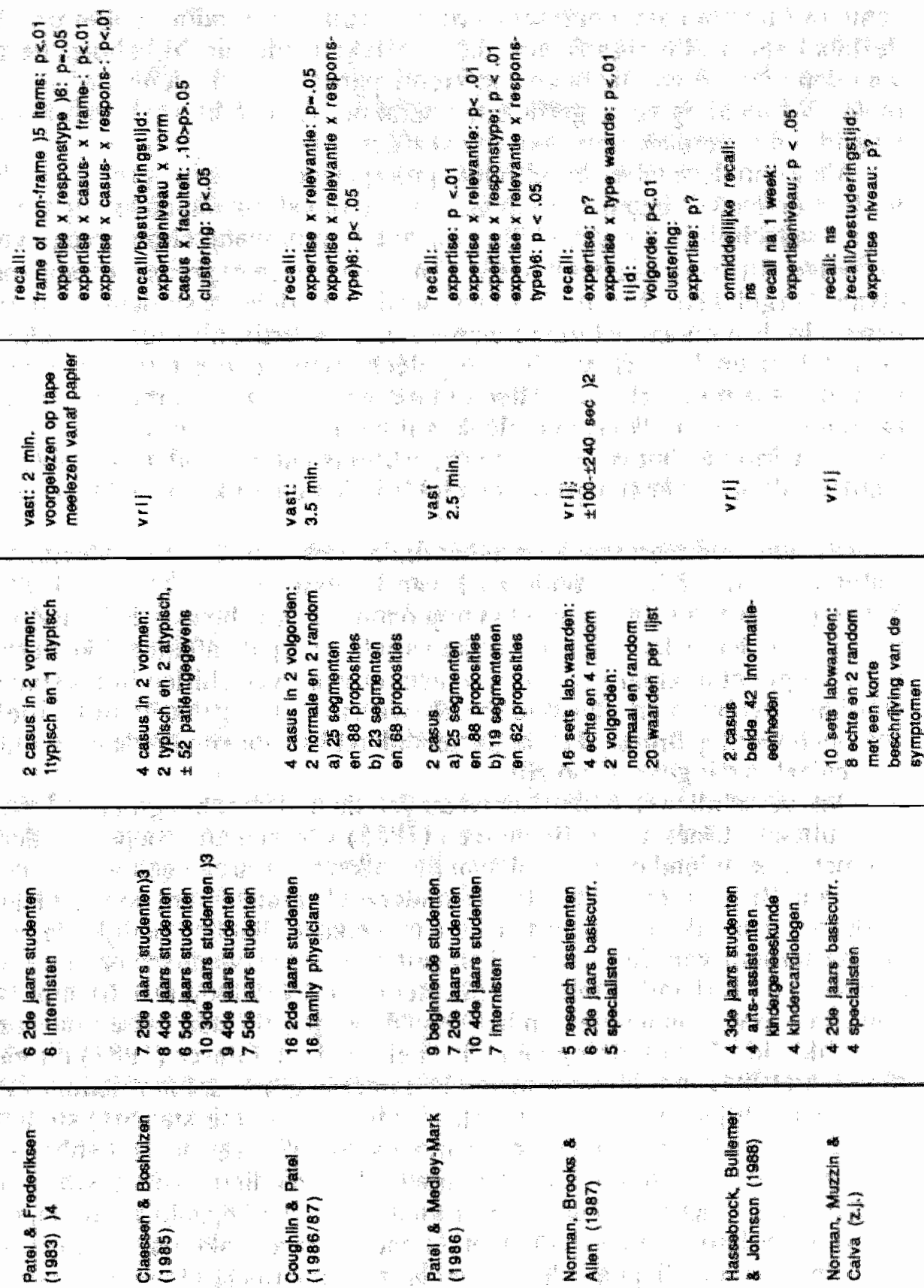

4. Een heranalyse van Muzzin, Norman, Feightner en Tugwell (1983)

5. Patel et al. verdelen de casus in medisch relevante (frame) en medisch niet relevante (non-frame) proposities.

6. Patel et al. onderscheiden responstype in letterlijke en geïnfereerde recall. In de analyse van Coughlin wordt een derde categorie toegevoegd, namelijk gedeeltelijke recal] 
echte of random data, gepresenteerd in normale of random volgorde. In de tabel staan alle significante hoofdeffekten met de bijbehorende pwaarden voor zo ver die in de conferentiepapers en artikelen worden vermeld. Vermelding van significante interakties is beperkt tot de interakties waarin een expertisecomponent aanwezig is.

Als we in deze tabel de gebruikte proefpersoongroepen vergelijken die in deze onderzoekingen werden gebruikt, dan valt op dat deze nogal van elkaar verschillen. Ze verschillen in aantal, in omvang en in niveau van expertise. In drie onderzoekingen ${ }^{3}$ zijn slechts twee expertiseniveaus met elkaar vergeleken. Het betreft hier steeds tweedejaars studenten en experts: In drie onderzoekingen werden vier expertiseniveaus met elkaar vergeleken en in vier studies vergeleek men de prestaties van drie niveaugroepen met elkaar. Alleen in die gevallen waarin men meer dan twee groepen met elkaar vergeleek, zal het mogelijk zijn iets te zeggen over de vorm van het verband van expertiseniveau met andere variabelen. Verder valt op dat er een groot verschil is in het gebruikte aantal proefpersonen.

Dit aantal varieert van acht in het onderzoek van Norman, Muzzin en Calva (z.j.) tot 47 in het onderzoek van Claessen en Boshuizen (1985). In een terrein zoals dit, waarin het nog onduidelijk is hoe sterk de invloed is van de onderzochte onafhankelijke variabelen op de afhankelijke variabelen, zegt het uiteraard weinig wanneer er geen verschillen in prestaties worden gevonden in een onderzoek waarin een gering aantal proefpersonen werd gebruikt. Het onderscheidend vermogen van de gebruikte toetsen zal in dat geval klein zijn.

Ook verschillen in expertiseniveau van de onderzochte groepen lopen sterk uiteen. Claessen en Boshuizen (1985) vergeleken groepen studenten met verschillend expertiseniveau met elkaar. Daarentegen vergeleken Norman, Brooks en Allen (1987) onderzoeksassistenten, jongerejaars studenten geneeskunde en specialisten met elkaar. Dit bemoeilijkt de vergelijkbaarheid van de onderzoeksresultaten, zeker wanneer er een niet strikt lineair verband wordt verondersteld. Ook De Jong (1986) stuit bij zijn analyse van onderzoek op het gebied van probleemoplossen op deze moeilijkheid. In navolging van Chi, Feltovich en Glaser (1981) en van Messick (1984) stelt hij voor te spreken over beginners, intermediates en experts, die hij als volgt omschrijft. Beginners zijn (eerstejaars) studenten, die een onderwijsonderdeel (een bepaald vak) afgesloten hebben en zich hebben voorbereid op een tentamen. Intermediates zijn gevorderde studenten, die naast een eerste confrontatie met een bepaald studieonderdeel ook verderop in hun studie met dit onderdeel te maken hebben gehad, hetzij in een meer diepgaande of toegepaste manier hetzij in relatie tot een ander vak. Experts zijn afgestudeerden. Bij deze indeling plaatst De Jong de kanttekening dat ook verdere gradaties natuurlijk mogelijk zijn, zoals

${ }^{3}$ Het onderzoek van Patel en Frederiksen (1984) is een heranalyse van het onderzoek van Muzzin, Norman, Feightner, Tugwell en Guyatt (1982). De heranalyse is niet betrokken in de vergelijking van de gebruikte onderzoeksmethoden. 
experts met veel en weinig ervaring. Claessen en Boshuizen (1985) vergeleken dus eigenlijk beginners en intermediates met elkaar, terwijl Norman et al. (1987) leken, beginners en experts met elkaar vergeleken.

Een ander verschil in de gebruikte methode betreft de bestuderingstijd. Meestal werd deze vrijgelaten (zes keer). Deze onderzoekingen kunnen ons in principe dus iets zeggen over de effekten van mate van expertise op de gebruikte bestuderingstijd. In de vier onderzoekingen waarin de bestuderingstijd werd gecontroleerd, was deze vaak aan de lange kant (Patel en Coughlin, 1986; Muzzin et al., 1982). Het onderzoek van Muzzin et al. (1983) wees echter uit dat de hoeveelheid toegestane bestuderingstijd van grote invloed is op de onderzochte effekten.

Een laatst verschil in methode, dat potentieel van belang kan zijn, betreft de wijze van recall. Meestal gebeurde dit schriftelijk, maar in twee onderzoekingen (Muzzin et al., 1982; Hassebrock et al., 1988) vond de recall mondeling plaats en werd deze opgenomen op tape. Ook de instruktie varieerde daarbij. Voor zo ver dit is te achterhalen, werd meestal aan de proefpersonen gevraagd zo letterlijk mogelijk op te schrijven wat ze zich nog konden herinneren. In het onderzoek van Patel en MedleyMark (1986) luidde de instruktie de casus samen te vatten. Deze verschillen in procedure bij de recall kunnen ook grote invloed hebben op de gevonden resultaten.

Hoeveelheid recall-Er werd voorspeld dat de hoeveelheid gegevens, die van een casus onthouden zullen worden, met een toenemend expertiseniveau zal stijgen tot een asymptoot. Deze afhankelijke variabele 'recall' komt in alle studies voor. Opvallend is echter dat slechts in een klein aantal daarvan significante resultaten gevonden worden. In zes onderzoekingen worden geen significante verschillen gevonden tussen proefpersonen met verschillend expertiseniveau in de hoeveelheid casusinformatie die zij reproduceren. In de opzet van deze zes onderzoekingen is niet één enkele factor aan te wijzen die dit verschijnsel kan verklaren. De onderzochte niveaus van expertise varieerden meestal van beginner tot expert, met uitzondering van het onderzoek van Claessen en Boshuizen (1985) dat geen experts bevatte. Het aantal proefpersonen liep uiteen van acht tot 47 , maar in de meeste onderzoekingen werden minder dan 30 proefpersonen gebruikt; oftewel maximaal acht proefpersonen per niveau van expertise. Het ontbreken van significante verschillen kan dus een gevolg zijn geweest van een te gering aantal proefpersonen en (in sommige gevallen) van een te kleine spreiding in gebruikte expertiseniveaus.

In vier van de elf studies worden wel effekten gevonden van expertiseniveau op de hoeveelheid recall. Een opvallend verschil met de hiervoor beschreven onderzoekingen waarin geen verschillen werden gevonden, betreft het laagste niveau van expertise dat in deze onderzoekingen werd geïncorporeerd. Zowel Patel en Medley-Mark (1986) als Norman, Brooks en Allen (1987) onderzochten ook de prestaties van leken op de voorgelegde taak. 
Voorspeld werd dat de hoeveelheid recall met een toenemend expertiseniveau zou stijgen tot een asymptoot. Slechts in éen van deze vier studies wordt een positief, stijgend verband tussen hoeveelheid recall en expertiseniveau gevonden (Norman et al, 1987). Zowel in de onderzoekingen van Patel en Medley-Mark (1986) als van Muzzin et al. (1983) reproduceerden de experts minder dan de intermediates. Bij Patel en MedleyMark kan dit effekt veroorzaakt zijn door de instruktie die zij gebruikten, namelijk de casus samen te vatten. Het is niet onwaarschijnlijk dat experts daartoe veel beter in staat zijn dan intermediates of beginnelingen en leken (Groen en Jerney, 1987), waardoor zij minder van de letterlijke tekst reproduceren. Muzzin et al. (1983) vinden alleen bij de cardiologische casus een significant verschil, niet bij de rheumatologische. Zij vermelden helaas geen ongesplitste hoofdeffekten. De resultaten van Hassebrock et al. (1988) laten we in deze vergelijking buiten beschouwing, omdat zij in eerste instantie geen, en pas na een week wel verschillen vonden. Dit laatste resultaat valt buiten het voorspellingsdomein van de hier geschetste meettheorie.

Deze analyses laten zien dat het onderzoek van Norman et al. (1987) nogal afwijkt van de overige studies. Het is heel jammer dat zij geen groep met een intermediair niveau van expertise in het onderzoek hebben opgenomen. De onderzoekingen die tot nu toe zijn gedaan, geven dus geen uitsluitsel over de relatie tussen expertiseniveau en hoeveelheid recall. De besproken onderzoekingen, met uitzondering van Norman et al. (1987), geven dus slechts zeer minimale ondersteuning aan de hypothese dat de hoeveelheid recall van een casusbeschrijving met een toenemend expertiseniveau tot een bepaalde asymptoot zal stijgen.

Bestuderingstijd-Voorspeld werd dat de snelheid waarmee een casus wordt gerepresenteerd, de bestuderingstijd, afneemt met een toenemend expertiseniveau. De effekten van mate van expertise op de feitelijke bestuderingstijd, wanneer deze wordt vrijgelaten, zijn echter weinig stabiel te noemen. Weliswaar blijken er grote verschillen tussen de proefpersonen onderling op te treden. In de zes experimenten waarin een vrije bestuderingstijd werd gehanteerd, wordt in geen enkel geval een p-waarde kleiner dan 05 gerapporteerd. In twee gevallen wordt een effekt van het expertiseniveau gemeld met een p-waarde die kleiner is dan .10. Dit is het geval in het onderzoek van Boshuizen en Claessen (1981) en bij Norman, Muzzin en Calva (z.j.), die tweedejaars studenten vergelijken met specialisten. Norman et al. (1987) rapporteren dat tweedejaars studenten een consistent langere bestuderingstijd nodig hebben dan leken en experts. Norman et al. (1979) melden geen effekten op bestuderingstijd, maar een nadere analyse van hun resultaten ${ }^{4}$ laat zien dat er sprake is van een afnemende bestuderingstijd bij een toenemend expertiseniveau $(F(3,16)=$

${ }^{4}$ Bereidwillig ter beschikking gesteld door G.R. Norman. 
$4.129, p=.024)$. Hassebrock et al. (1988) vermelden geen bestuderingstijden.

Ook de hoeveelheid recall, gedeeld door de bestuderingstijd kan beschouwd worden als een maat voor de representatiesnelheid. In twee van de vier onderzoekingen waarin deze variabele is gebruikt, worden effekten van de mate van expertise gerapporteerd met een $\mathrm{p}$-waarde kleiner dan .05. Norman et al (1979) melden een toename van de gecorrigeerde recall voor de diagnosticeerbare casus bij toenemende expertise ( $\mathrm{p}$ kleiner dan .01), terwijl ook het verschil tussen de experts en beginners in het onderzoek van Norman, Muzzin en Calva ( $\mathrm{z} . \mathrm{j}$ ) in dezelfde richting gaat (geen p-waarde gerapporteerd).

Deze resultaten lijken erop te wijzen dat er wel degelijk een relatie bestaat tussen de mate van expertise en de snelheid waarmee gegevens uit de casus worden gerepresenteerd. Dat deze relatie op casusniveau minder duidelijk is dan op itemniveau wijst er wellicht op dat andere processen de veronderstelde relatie verstoren.

Inferenties- Voorspeld werd dat het aantal inferenties zou toenemen met een toenemend expertiseniveau. Zowel in de onderzoekingen van Patel en haar medewerkers (Coughlin en Patel, 1986; Patel en Frederiksen, 1984; Patel en Medley-Mark, 1986) als in het onderzoek van Hassebrock et al. (1988) werd de hoeveelheid inferenties in de analyses betrokken. Helaas helpen deze onderzoekingen ons niet verder bij de beoordeling van de validiteit van de geschetste theorie. In geen van de onderzoekingen worden aparte analyses gerapporteerd op het aantal inferenties dat door de verschillende groepen wordt geproduceerd. De resultaten worden steeds multivariaat getoetst met gebruikmaking van een factor responstype met tenminste twee niveaus, letterlijke recall en inferentie. Bovendien blijken deze onderzoekers een definitie van 'inferentie' te hanteren (met uitzondering van de 'high-level inferences' van Coughlin en Patel,1987), die niet aansluit bij de gedane voorspelling. De geschetste theorie voorspelt een toename van het aantal inferenties, die gebaseerd zijn op meer dan één gegeven. Over andere typen inferenties wordt geen uitspraak gedaan. Bij Patel en Frederiksen (1984) en Patel en Medley-Mark (1986) omvat de definitie van inferentie daarentegen alle conclusies en interpretaties die gedaan zijn op grond van én of meer gegevens. Het is dus niet mogelijk om op grond van reeds bestaande onderzoekingen uitspraken te doen omtrent de juistheid van de voorspelling.

Samenhang in de recall- Voorspeld werd dat de mate van samenhang in de recall zou stijgen met een toenemend niveau van expertise. De mate van clustering, een maat voor de samenhang in de recall, is in drie studies berekend; in alle drie bleek het effekt van de mate van expertise op deze variabele duidelijk aanwezig te zijn. In het onderzoek van Boshuizen en Claessen (1981) werd bij vier groepen, die uiteenliepen van tweedejaars studenten tot huisartsen, een toenemende mate van clustering geconstateerd $(\mathrm{p}<.05)$. Claessen en Boshuizen (1985) constateerden hetzelfde, 
terwijl daar sprake was van een beduidend geringere spreiding in de expertiseniveaus van de proefpersonen. Norman, Brooks en Allen (1987) ten slotte vonden hetzelfde, maar bij een veel grotere spreiding in expertiseniveau, namelijk van leken tot experts. De resultaten van deze drie onderzoekingen zijn dus conform de voorspelling.

Samenvattend komt uit de recallstudies duidelijk naar voren dat medische expertise op meerdere wijzen tot uitdrukking kan komen in de verwerking, representatie en recall van een medische casus. Soms blijkt expertise in de hoeveelheid tijd die iemand nodig heeft voor bestudering van een casus. Soms komt expertise tot uitdrukking in hetgeen men zich van een casus weet te herinneren, maar vaker komen deze twee variabelen pas in een samenspel tot uiting (hetgeen weergegeven wordt door de recall die gecorrigeerd is voor de gebruikte bestuderingstijd). Pas wanneer weinig tijd beschikbaar is of bij een voldoende grote spreiding in mate van expertise komen zuivere effekten voor. Een grotere constantie in resultaten wordt gevonden bij de clustering die in de recall optreedt. Het is heel aannemelijk dat deze variabele niet of in ieder geval in minder sterke mate doorkruist wordt door verschillen in bestuderingstijd.

De resultaten van de besproken recallstudies ondersteunen slechts gedeeltelijk de hypothesen die in het voorafgaande zijn geformuleerd. Ze bevestigen bijvoorbeeld niet dat een toenemend expertiseniveau gepaard gaat met een hoeveelheid recall, die toeneemt tot een asymptoot en met een afnemende bestuderingstijd. Beide resultaten werden slechts in één onderzoek aangetroffen. De analyses van de recallstudies wezen uit dat een te gering aantal proefpersonen, gekoppeld aan een grote proefpersoonvariantie hieraan mogelijk ten grondslag ligt. De besproken onderzoekingen leenden zich er niet toe een uitspraak te doen over de relatie tussen expertiseniveau en het aantal inferenties. Alleen waar het de samenhang in de recall betrof, werd de gestelde hypothese unaniem ondersteund.

Vooral de bevindingen die betrekking hebben op de hoeveelheid recall en de hoeveelheid gebruikte bestuderingstijd zijn erg onplezierig. De analyse van de beschreven onderzoekingen tonen echter aan dat er zo veel tekortkomingen aan deze studies kleven dat vooralsnog niet geconcludeerd kan worden of er wel of geen verband bestaat tussen expertiseniveau enerzijds en recall en bestuderingstijd van een casusbeschrijving anderzijds. De hypothesen die eerder in dit hoofdstuk werden opgesteld, blijven dus gehandhaafd.

Teneinde deze hypothesen te onderzoeken werd een onderzoek uitgevoerd waarin rekening werd gehouden met de tekortkomingen, die we in de besproken experimenten signaleerden. We gebruikten daarom 64 proefpersonen, verdeeld over vier expertiseniveaus met een gelijkmatig spreiding over het spectrum van beginneling tot expert: één groep beginners, twee groepen intermediates en éen groep experts. Deze proefpersonen kregen bij een vrije, doch gemeten bestuderingstijd twee casus voor- 
gelegd, die zij moesten diagnosticeren. Daarna volgde de recall. Op grond van de eerder geformuleerde hypothesen kunnen de volgende voorspellingen worden geformuleerd:

a) De uitgebreidheid en de coherentie van de interne representatie zal toenemen met een toenemend expertiseniveau, hetgeen tot uitdrukking zal komen in een continu stijgende hoeveelheid recall die nadert tot een asymptoot;

b) De hoeveelheid tijd die voor de opbouw van de interne representatie gebruikt wordt, zal afnemen met een toenemend expertiseniveau, zodat

c) de hoeveelheid recall gecorrigeerd voor de gebruikte bestuderingstijd zal toenemen met een toenemende mate van expertise;

d) Met een toenemend expertiseniveau zal in steeds grotere mate gebruik worden gemaakt van het geaktiveerde en geinstantieerde probleemmodel bij de recall, hetgeen tot uitdrukking zal komen in een toename van het aantal inferenties in de recall en

e) in een toenemende mate van clustering in de recall volgens een patièntpresentatieschema.

f) Bovendien verwachten we dat met een toenemend expertiseniveau de diagnostische accuratesse zal stijgen.

Deze voorspellingen zullen in het hierna volgende onderzoek, Experiment 1, worden onderzocht. Aangezien in veel van de geanalyseerde experimenten de vorm van de casus als tweede onafhankelijke variabele was opgenomen, is dit in het huidige experiment ook gedaan. De gebruikte casus zullen in een typische of atypische vorm worden gepresenteerd. Deze manipulatie zal niet van invloed zijn op de constructie van de textbase aangezien de gebruikte terminologie geen verschillen in bekendheid met zich mee zal brengen. We mogen echter verwachten dat de aktivatie van een passend probleemmodel bij een atypische casus moeilijker zal zijn dan bij een typische casus. Dit zal dus tot uitdrukking komen in de snelheid van informatieverwerking die zal toenemen en in het aantal inferenties, dat zal afnemen.

\section{EXPERIMENT 1}

\section{Onderzoeksopzet}

\section{Materiaal}

Voor dit onderzoek werden de casusbeschrijvingen van twee echte patiênten gebruikt. Beide casusbeschrijvingen waren afkomstig uit een verzameling van patiëntbeschrijvingen, die in de loop van een aantal jaren ten behoeve van het onderwijs door een aantal huisartsen uit de regio Maastricht zijn bijeen gebracht. ${ }^{5}$ Deze werden aangevuld met een aantal extra anamnese- en onderzoeksgegevens tot een totaal van circa 55 gegevens. In deze gegevens zijn diverse soorten vertegenwoordigd: persona-

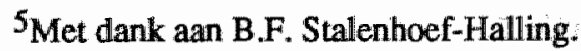


lia van de patiënt, de medische voorgeschiedenis, klacht, uitdieping van de klacht, verdere anamnese, algemeen en specifiek lichamelijk onderzoek en laboratoriumuitslagen. Het aantal gegevens dat in de casusbeschrijvingen werd opgenomen, is bepaald op grond van het aantal informatieeenheden dat door huisartsen en internisten in simulatieonderzoekingen verzameld werd. De huisartsen in het onderzoek van Gerritsma en Smal (1982) verzamelden gemiddeld 62 gegevens $^{6}$ (tegenover de internisten die er gemiddeld 129 verzamelden).

De eerste casus betrof een 38 -jarige man met een voorgeschiedenis van neurotische depressies, leidend tot arbeidsongeschiktheid en alcoholmisbruik. Een jaar geleden is hij opgenomen geweest wegens een aanval van pancreatitis. In die tijd heeft hij ook een ontwenningskuur ondergaan. Nu belt hij om 9 uur 's avonds de huisarts wegens continue pijn in de bovenbuik die doortrekt naar de rug. Anamnese, lichamelijk onderzoek en laboratoriumbepalingen wijzen op een nieuwe aanval van pancreatitis. Bovendien blijkt dat hij sinds een half jaar weer drinkt en dat zijn psychische gesteldheid labiel is.

De andere casus betreft een man van 55 jaar. Uit de medische voorgeschiedenis zijn niersteentjes bekend. Verder komen er in zijn familie cardiovasculaire aandoeningen voor. Het betreft een visite na telefonisch verzoek van de echtgenote. Zijn klacht is dat hij de hele nacht niet heeft kunnen slapen van de buikpijn in de onderbuik. Bovendien heeft hij duidelijk koorts. Anamnese, lichamelijk onderzoek en laboratoriumbepaling wijzen uit dat er sprake is van prostatitis.

Van beide casus werden twee varianten gemaakt, een typische variant en een atypische variant. In de typische variant werd zo veel mogelijk de oorspronkelijke casusbeschrijving gebruikt. Deze werd aangevuld met bijpassende extra informatie, die veelal de verdere anamnese en algemeen lichamelijk onderzoek betrof. Op basis van deze typische casus werd een atypische variant geconstrueerd?. Dit gebeurde als volgt. Een aantal gegevens, die in de typische variant waarden hebben die in het algemeen bij de betreffende ziekte worden gevonden, worden zodanig veranderd, dat ze niet meer kenmerkend zijn voor de betreffende aandoening, maar toch de diagnose (atypische) pancreatitis of prostatitis niet behoeven uit te sluiten. Zo bleven bijvoorbeeld in de prostatitiscasus onveranderd de plaats, aard en de duur van de pijn, was de mictie nog steeds bemoeilijkt en frekwenter, maar was er sprake van een branderig gevoel bij het plassen in plaats van pijn. De pijn blijft erger bij zitten dan bij liggen, maar er is geen sprake van een pijnlijke defecatie. De patiènt meldt daarentegen af en toe last te hebben van obstipatie. Bij rectaal toucher wordt in de atypische variant slechts een drukgevoelige prostaat gevonden.

Deze casus werden op systeemkaarten gepresenteerd. Op iedere kaart werd eén gegeven of een aantal direkt samenhangende gegevens gepre-

6J.A. Smal, persoonlijke mededeling, januari 1981.

${ }^{7}$ Door B.F. Stalenhoef-Halling en J.A.M. Galensloot. 
senteerd. Dit resulteerde voor de prostatitiscasus in 47 en voor de pancreatitiscasus in 48 kaarten. Voorbeelden daarvan vindt $u$ hieronder. In Bijlage 2 is het volledige materiaal weergegeven.

\begin{tabular}{|l|}
\hline man, gehuwd, 38 jaar, 2 kinderen \\
\hline \begin{tabular}{l|} 
(voorgeschiedenis) \\
1 jaar geleden eenmalige refusalkuur
\end{tabular} \\
\begin{tabular}{|l|}
\hline \\
(anamnese) \\
pijn is sindsdien steeds toegenomen, is nu constant
\end{tabular} \\
$\begin{array}{ll}\text { (onderzoek) } & \text { lichte drukpijn in de onderbuik, } \\
\text { abdomen, palpatie: } & \text { niet scherp gelokaliseerd; } \\
\text { geen défense musculair }\end{array}$ \\
\hline
\end{tabular}

\section{Proefpersonen}

Aan het onderzoek namen 16 tweedejaars, 16 vierdejaars en 16 vijfdejaars studenten en 16 huisartsen deel. De werving van de studenten liep als volgt. Een aselekte steekproef van 35 studenten per jaargroep ontving een uitnodiging om deel te nemen aan het onderzoek en daartoe een afspraak met de onderzoekers te maken. Na anderhalve week werden degenen die niet gereageerd hadden nogmaals benaderd en werd zo mogelijk rechtstreeks telefonisch contact met ze gezocht. Op deze manier werden gemiddeld 12 studenten per groep geworven. De rest meldde zich spontaan of werd via andere deelnemers aan het onderzoek geworven. De huisartsen werden allen persoonlijk door de onderzoekers benaderd. Het betrof daarbij in hoofdzaak praktiserende huisartsen. Verder nam een klein aantal huisartsen deel, die kort daarvoor hun eigen praktijk hadden opgegeven en als medewerker aan de universiteit zijn verbonden. De proefpersonen ontvingen een kleine vergoeding voor hun medewerking.

\section{Generaliseerbaarheid}

De aard en de omvang van de taken die in dit onderzoek aan de proefpersonen worden voorgelegd, brengen met zich mee dat het aantal casus dat aan de proefpersonen kan worden voorgelegd, beperkt is. Daardoor is het onmogelijk een representatieve afspiegeling van het aanbod van problemen in de praktijk te bereiken. Integendeel, de casus zijn in het geheel niet representatief voor de huisartsgeneeskunde. Yolgens Hodgkin (1978) is de incidentie van acute prostatitis 0.2 a 0.4 per 1000 patiënten per jaar. Lamberts (1984) komt met iets hogere cijfers, namelijk 1.7 a 2.1 per 1000 patiënten per jaar. Voor pancreatitis zijn die cijfers nog lager, namelijk minder dan 1 geval per 1000 per jaar. Ook de manier waarop de casus is uitgewerkt vormt geen goede afspiegeling van de manier waarop 
de doorsnee huissarts bij dit soort consulten te werk zou gaan. Daarvoor bevatten ze te veel algemeen lichamelijk onderzoek en tractusanamnese.

Ons uitgangspunt bij de keuze en de uitwerking van de casus heeft dan ook geen representativiteit beoogd. De casus zijn zodanig gekozen dat ze zowel voor artsen als voor ouderejaars studenten geen routinegevallen betreffen, terwijl ze ook weer niet zo moeilijk zijn dat jongerejaars studenten er geen kant mee uitkunnen. De uitgebreidheid van de casus is bedoeld om aan de grotere informatiebehoefte van personen met minder kennis op een bepaald gebied tegemoet te komen (Elshout, 1976).

\section{Verloop van het experiment}

De proefpersonen kregen zowel een prostatitis- als een pancreatitiscasus voorgelegd: de ene casus in de typische vorm en de andere casus in de atypische vorm. Dit gebeurde in gebalanceerde volgorde, volgens een rotatieschema (zie Figuur 2.1).

\section{eerste casus}

pp $1,5,9,13$

pp $2,6,10,14$

pp $3,7,11,15$

pp $4,8,12,16$ typische prostatitis

atypische

prostatitis

typische pancreatitis

atypische pancreatitis tweede casus

atypische pancreatitis

\section{typische pancreatitis}

atypische prostatitis

typische prostatitis

Figuur 2.1 Rotatieschema waarmee per proefpersoon de vorm en de aanbiedingsvolgorde van de casus werd bepaald.

Opdracht aan de proefpersonen was de casus te diagnosticeren. Daartoe moesten ze de kaarten één voor één hardop denkend ${ }^{8}$ doornemen en na inlevering van de kaarten een diagnostische hypothese of differentiaal diagnose produceren. In de bestuderingsfase was het toegestaan terug te kijken, maar niet om kaarten over te slaan of vooruit te bladeren. De tijd die de proefpersonen daarvoor nodig hadden, werd genoteerd. Hierna werd hen gevraagd alles op te schrijven wat ze zich nog konden herinneren van de gegevens en deze zo letterlijk mogelijk op te schrijven in de volgorde waarin het in ze opkwam.

\footnotetext{
${ }^{8}$ Dit hoofdstuk handelt uitsluitend over de relatie tussen expertise en recall van informatie als maat voor de interne representatie daarvan, De analyse van de hardopdenk protocollen als on-line methode voor de bestudering van de interne representatie komt in een volgend hoofdstuk aan de orde.
} 


\section{Analyse}

Diagnostische hypothesen-De differentiaal diagnose werd als volgt gescoord: twee punten wanneer de juiste diagnose als meest waarschijnlijke mogelijkheid werd genoemd. Bij de typische pancreatitiscasus was dit het geval wanneer 'pancreatitis' of 'nieuwe aanval van chronische pancreatitis met exacerbaties' wordt genoemd; bij de atypische pancreatitiscasus was dit het geval bij 'pancreatitis", 'atypische pancreatitis' of 'chronische pancreatitis'. Bij de beide prostatitiscasus werd alleen de diagnose 'prostatitis' als volledig goed gerekend. Er werd één punt toegekend wanneer genoemde diagnosen op een andere dan de eerste plaats in de differentiaal diagnose voorkwamen. In alle andere gevallen werd 0 punten toegekend.

\section{Free recall}

Analyse van de aangeboden teksten-Teneinde de free recallprotocollen te kunnen analyseren werden zowel de aangeboden casus als de free recallprotocollen opgesplitst in informatie-eenheden. De methode die daarvoor veelal gebruikt wordt, bestaat in wezen uit de identificatie van onderwerp-gezegde combinaties die één bepaald idee uitdrukken. Vaak kunnen ze in een tekst geindenticifeerd worden door voegwoorden, betrekkelijk voornaamwoorden en punten of puntkomma's te markeren (Schmidt, 1982). De zin 'Onderzoek van de lieskanalen toont geen zwelling, waarbij geen drukpijn wordt geconstateerd, bestaat dus uit twee informatie-eenheden, namelijk 'Onderzoek van de lieskanalen toont geen zwelling,' en 'waarbij geen drukpijn wordt geconstrateerd'

Andere methoden bestaan uit het identificeren van sequenties en eventueel daarin besloten clausen. Dit gebeurt op grond van de aanwezigheid van een verbogen werkwoord. Dezelfde zin als hiervoor is gebruikt, bevat volgens de methode van Patel, Frederiksen en Groen (1983) (ontleend aan Frederiksen, 1975) twee sequenties en twee clausen. Deze laatste komen overeen met Schmidts informatie-eenheden. Maar daarna gaat de analyse verder en worden uit deze clausen proposities gedestilleerd (zie Figuur 2.2). Beide bovengenoemde clausen bevatten weer drie proposities. Analyse op propositieniveau is dus veel gedetailleerder dan analyse op het niveau van de informatie-eenheid. Maar behalve dat, wordt met een propositie-analyse beoogd een representatie van de tekst te verkrijgen die in zekere zin los staat van de specifieke tekst. De propositie-analyse van claus 2 die hieronder is weergegeven, is bijvoorbeeld net zo goed van toepassing op een claus als: 'daarbij werd er geen drukpijn geconstateerd:.

\begin{tabular}{|lll|}
\hline \multicolumn{2}{|c|}{ claus 1: } & Onderzoek van de lieskanalen toont geen zwelling, \\
\hline 1.1 & tonen & pat: (onderzoek); them: $(1,3)$ \\
\hline 1.2 & onderzoeken & loc.: (lieskanalen) \\
\hline 1.3 & zwelling & neg.: (geen) \\
\hline
\end{tabular}




\begin{tabular}{|c|c|c|}
\hline 2.1 & constateren & pat: (1.2), tense: (ind.); them.: (2.2) \\
\hline 2.2 & drukpijn & neg.: (geen) \\
\hline 22 & temp (daarbij) & equiv: $(1.2)(2.1)$ \\
\hline
\end{tabular}

Figuur 2.2 Propositieanalyse volgens de methode van Patel, Frederiksen en Groen (1983) van de zin 'Onderzoek van de lieskanalen toont geen zwelling, waarbij geen drukpijn wordi geconstateerd:

Beide typen methoden zijn voor het huidige doel niet zonder meer geschikt. Door het feit dat de teksten op de kaarten vaak in telegramstijl gesteld zijn, is het moeilijk een gangbare analysemethode ongewijzigd op de gebruikte casus toe te passen. Eén van de redenen daarvoor is dat werkwoorden vaak worden weggelaten en juist de werkwoorden vormen de spil van genoemde analysetechnieken. Dit is bijvoorbeeld het geval bij de inhoud van kaart 36 van de prostatitiscasus.

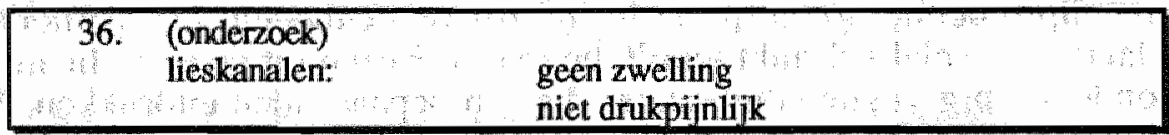

Deze tekst zou een weergave in telegramstijl kunnen zijn van de hierboven geanalyseerde zin: 'Onderzoek van de lieskanalen toont geen zwelling, waarbij geen drukpijn wordt geconstateerd: Maar een andere formulering als Onderzoek van de lieskanalen brengt geen zwelling en geen drukpijn aan het licht' is even goed mogelijk.

Het voordeel dat propositie-analyse relatief ongevoelig is voor variaties in de recall waarbij de betekenis van de oorspronkelijke tekst gehandhaafd blijft, vormt geen dwingende reden om de tekst op een dermate gedetailleerd niveau te analyseren. Door invoering van een scoringscategorie 'parafrase' kan een vergelijkbaar effekt bereikt worden.

Deze overwegingen hebben ertoe geleid dat bij het opsplitsen van de kaartteksten in informatie-eenheden veelal voorbij gegaan is aan de precieze kenmerken van de tekst. Een bijkomende reden daarvoor wordt gevormd door het feit dat een aantal informatie-eenheden feitelijk bestaat uit een episode uit de medische voorgeschiedenis van de patiënt, zoals bijvoorbeeld het geval is bij kaart 5,6 en 7 van de beide prostatitiscasus:

\begin{tabular}{|c|c|}
\hline 5. & $\begin{array}{l}\text { (voorgeschiedenis) } \\
8 \text { jaar geleden cardiologisch onderzoek zonder klachten; } \\
4 \text { broers hadden een hartinfarct; } \\
\text { geen afwijkingen. }\end{array}$ \\
\hline 6. & $\begin{array}{l}\text { (voorgeschiedenis) } \\
3 / 4 \text { jaar geleden } 2 \text { keer niersteentje links, } \\
\text { spontaan geloosd. }\end{array}$ \\
\hline
\end{tabular}


7. (voorgeschiedenis)

enkele maanden geleden KNO-arts;

allergische rhinitis en sinusitis.

Deze teksten hebben niet alle dezelfde struktuur. Toch gaat het steeds om episodes die wel dezelfde struktuur hebben gehad: De patiënt heeft op een zeker ogenblik (een bepaalde tijd geleden) de arts geraadpleegd met een klacht of een verzoek (niersteentjes, verkoudheid, of ongerustheid over het hart); dat consult heeft een bepaald vervolg gehad (b.v. onderzoek bij de cardioloog waarbij geen afwijkingen werden gevonden) en/of de klacht heeft zich op een bepaalde manier ontwikkeld (spontaan uitgeplaste niersteentjes). Door deze overeenkomsten in het verloop van dergelijke episoden verdient het de voorkeur ze op uniforme wijze te analyseren en in zekere mate voorbij te gaan aan de variaties in de teksten, die overigens alle in een telegramstijl zijn gesteld. Kern daarbij is steeds de klacht (of de interpretatie die de arts daaraan heeft gegeven). Tijdstip en verloop worden daar als het ware aan opgehangen. Wanneer op de kaart een klacht of verzoek aan de huisarts afwezig is, wordt het medisch vervolg of het verloop op de centrale plaats gesteld. Dit laatste is bij voorbeeld het geval bij de tekst op kaart 5 , die slechts met veel inlegkunde omgewerkt kan worden tot een episode als hierboven is geschetst.

De methode die uiteindelijk gebruikt is voor het opsplitsen van de kaartteksten in informatie-eenheden of idea units bevat de volgende kenmerken:

a) Uitgangspunt is de medische bevinding. Eén medische bevinding is én informatie-eenheid. Een medische bevinding moet ruim worden genomen. Het kan zowel bestaan uit een antwoord op een (eventueel niet weergegeven) vraag, een onderzoeks- of laboratoriumbevinding, maar ook uit een episode uit de voorgeschiedenis of een element van de persoonsbeschrijving, die een arts normaliter op de groene kaart heeft staan.

b) In geval van telegramstij1 wordt de tekst herschreven tot zo kort mogelijke zinnetjes.

c) Op basis van deze zinnetjes wordt besloten of iets een afzonderlijke informatie-eenheid vormt, dan wel een toevoeging is bij een eerder element.

d) Duidelijk herkenbare episodes uit de voorgeschiedenis worden standaard beschreven als een klacht, waaraan een aantal andere kenmerkende elementen van de betreffende episode verbonden zijn. Bij het ontbreken van de klacht, die tot die episode aanleiding gaf, wordt de vervolgaktie (medicatie, doorverwijzen) op de centrale plaats gezet.

Sommige informatie-eenheden bevatten veel meer informatie dan andere. Dit is bijvoorbeeld het geval bij de volgende gegevens uit de anamnese in de typische pancreatitiscasus: 


\section{8. (anamnese)}

hij heeft 2 dagen geleden geprobeerd overal een einde aan te maken door 6 tabletten Mogadon met flink veel alcoholica in te nemen

\section{4. (anamnese)}

eetlust: slecht.

Om recht te doen aan deze verschillen in hoeveelheid informatie, is een variant op de propositieanalyse gebruikt waarbij de informatie-eenheden opgesplitst worden in een kern en de daarbij behorende specificaties als tijds(duur)aanduiding, lokatie en effekt. Dit gebeurt echter zonder de specifieke notatie met al z'n lege slots te gebruiken. De twee voorbeelden worden dan als volgt geanalyseerd:

\begin{tabular}{|cc|}
\hline 20.2 & (A) geprobeerd overal een einde aan te maken \\
\hline 20.2 .1 & met 6 tabletten Mogadon \\
\hline 20.2 .2 & en flink veel alcoholica \\
\hline 20.2 .3 & 2 dagen geleden \\
\hline
\end{tabular}

\subsection{A: eetlust: slecht}

Scoring-De feitelijke scoring van de free recallprotocollen verliep als volgt. Om de omvang van de interne representatie van de casusinformatie te bepalen werden de door de proefpersonen geproduceerde teksten opgedeeld in informatie-eenheden. Dit gebeurde op vergelijkbare wijze als eerder met de aangeboden casus is gedlaan. Deze informatie-eenheden werden vergeleken met de opgedeelde tekst van de aangeboden casus, waarbij bepaald werd of een element uit het recallprotocol afgebeeld kon worden op een element van de geanalyseerde casus. Hierna bleef er een aantal elementen over die niet eenduidig aan één informatie-eenheid kunnen worden gekoppeld. Van deze recall-elementen wordt vervolgens bepaald of ze beschouwd kunnen worden als een conclusie uit of een samenvatting van meerdere gegevens. Zo kan het recall-element 'eetpatroon: vet eten' niet rechtstreeks gekoppeld worden aan é́n informatieeenheid, omdat deze conclusie zowel gebaseerd kan zijn op de gegevens over de eetgewoonten van de patiënt als op diens menu van vandaag en gisteren. Deze recall-elementen werden als 'inferenties' aangemerkt.

Voor de vaststelling van de omvang van de interne representatie werden het totaal aantal juiste recall proposities en het aantal inferenties bepaald. Optelling van beide somscores levert de omvang van de interne representatie.

Clustering in de recall- Om te onderzoeken in welke mate de probleemrepresentatie van de proefpersonen de sporen vertoonde van een patiëntpresentatieschema, werd van alle casusgegevens bepaald tot welke categorie van dat schema ze behoorden: personalia en medische voorge- 
schiedenis, klacht en setting waarin de klacht wordt gepresenteerd, klachtuitdieping en speciële anamnese, tractusanamnese, onderzoek specifiek gericht op de klacht, overig lichamelijk onderzoek en laboratoriumonderzoek. Een proefpersoon die dit schema hanteert, zal eerst alle gegevens omtrent personalia en medische voorgeschiedenis vermelden, en via de klacht, anamnese en onderzoek eindigen bij de laboratoriumgegevens. Een proefpersoon die dit schema niet hanteert, zal alle gegevens door elkaar gooien en bijvoorbeeld beginnen met laboratoriumgegevens (een recency effect), en daarna iets opschrijven over het lichamelijk onderzoek, dan iets over de persoon van de patiënt, daarna weer iets over het onderzoek, en zo verder.

De mate van schemagebruik werd uitgedrukt in de ARC, Adjusted Ratio of Clustering van Roenker, Thompson en Brown (1971). Deze maat is gebaseerd op het aantal malen dat de proefpersoon in de recall wisselt van categorie, zoals in het voorbeeld is geillustreerd. In ons geval wordt, wanneer alle categorieën in de recall van de proefpersoon voorkomen, bij maximale clustering dus acht keer op een andere categorie overgegaan. Roenker et al. (1971) ontwikkelden hiervoor de volgende formule:

$$
A R C=\frac{(R-E(R))}{(\max R-E(R))}
$$

Hierin is $\mathbf{R}$ het aantal malen dat een gereproduceerd gegeven uit een bepaalde categorie direkt volgt op een gegeven uit dezelfde categorie. MaxR is het maximum voor $R$ en hangt dus samen met het totale aantal gegevens en het totaal aantal categorieën. $E(R)$ is de waarde van $R$ die op basis van toeval verwacht kan worden. De termen worden als volgt berekend:

$$
\max R=n-c
$$

Hierbij is $n$ gelijk aan het aantal gerecallde items. Het aantal categorieën dat in de recall voorkomt wordt weegegeven door c. De laatste term $E(R)$ wordt als volgt berekend:

$$
E(R)=\left(\frac{\sum_{i} n_{i}^{2}}{n}\right)-1
$$

De methode is helaas niet sensitief voor de volgorde waarin de categorieèn in de recall voorkomen. Een proefpersoon die begint bij de persoonsbeschrijving en eindigt bij de labgegevens, krijgt een even hoge clusteringsscore als iemand die eerst alle labgegevens, dan alle gegevens uit het lichamelijk onderzoek, en daarna de persoonsgegevens opsomt, terwijl deze laatste representatiewijze niet aansluit bij de standaardmanier.

\section{Resultaten}

Hoeveelheid recall-De eerste voorspelling, die we hier toetsen, luidt dat de omvang van de inteme representatie, uitgedrukt in de hoeveelheid recall, zal toenemen met een toenemend expertiseniveau. In Figuur 2.3 is 
de hoeveelheid recall (gemiddeld aantal juiste proposities plus inferenties) van de verschillende groepen weergegeven. Variantieanalyse op de hoeveelheid recall toont aan dat het effekt van de variabele 'niveau van expertise' significant is $(\mathrm{F}(3,60)=3.108, \mathrm{p}=.033)$. De hypothese dat er spra$k e$ is van een monotone stijging van de hoeveelheid recall met een toenemend expertiseniveau wordt echter niet bevestigd. Componentanalyse toont aan dat er geen lineaire trend is $(F(1,60)=2.8019, p=.10$, met significante deviaties van lineariteit $(\mathrm{F}(2,60)=3.262, \mathrm{p}=.045)$. De kwadratische term in de relatie tussen niveau van expertise en hoeveelheid recall is wel significant $(\mathrm{F}(1,60)=6.3458, \mathrm{p}=.0144$, waarbij er geen sprake is van significante deviaties $(\mathrm{F}(2,60)=.1774, \mathrm{p}=.6751)$.

Op grond van deze resultaten moet de hypothese dat de hoeveelheid recall stijgt met een toenemende mate van expertise verworpen worden. Eerder is er sprake van een omgekeerd U-vormig verband.

Beide andere factoren: vorm van de casus $(\mathrm{F}(1,60)=.026, \mathrm{p}=.8735)$ en de interaktie tussen expertiseniveau en vorm van de casus $(F(3,60)=$ $.483, \mathrm{p}=.6956$ ) leveren geen significante resultaten, hetgeen conform de verwachting is.

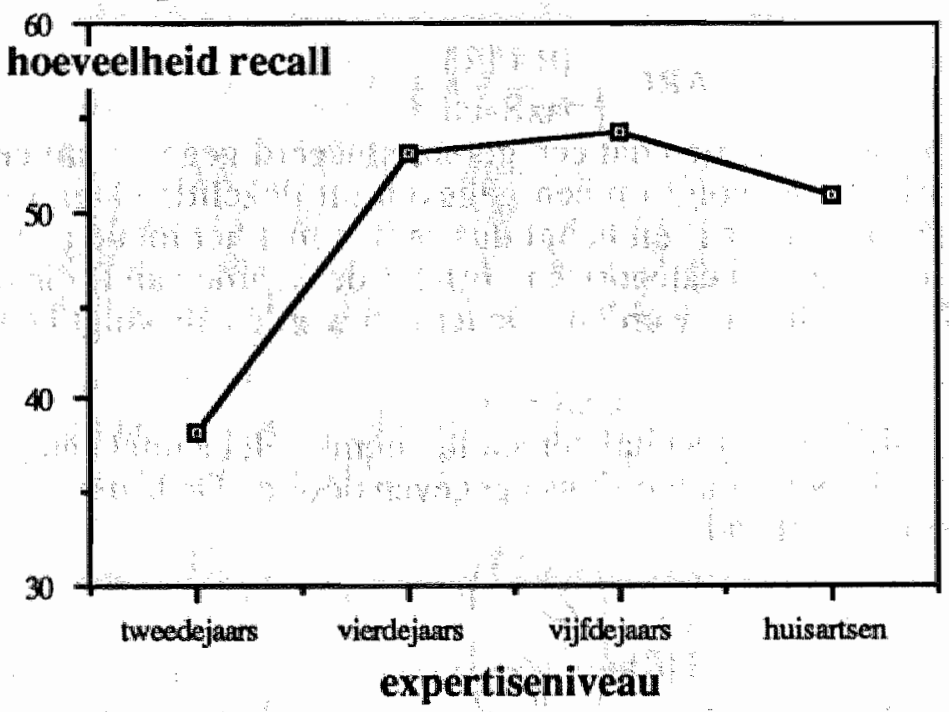

Figuur 2.3 Omvang van de probleemrepresentatie, uitgedrukt in de hoeveelheid recall.

Bestuderingstijd-Ten tweede veronderstelden we dat de hoeveelheid tijd, die gebruikt zou worden voor het vormen van de interne representatie van de casus af zal nemen met een toenemend expertiseniveau. De gemiddelde bestuderingstijd die de vier groepen gebruikten, zijn weergegeven in Figuur 2.4. De variantieanalyse waarmee deze voorspelling werd getoetst, leverde echter geen significante resultaten op. Het expertiseniveau $(F(3,60)=1.623, p=.1934)$, noch de vorm van de casus $(F(1,60)=$ $.541, \mathrm{p}=4651$ ), noch de interaktie tussen beide factoren $(F(3,60)=.277$, $\mathrm{p}=.8416$ ) laten een overschrijdingskans zien die kleiner is dan 05 . 


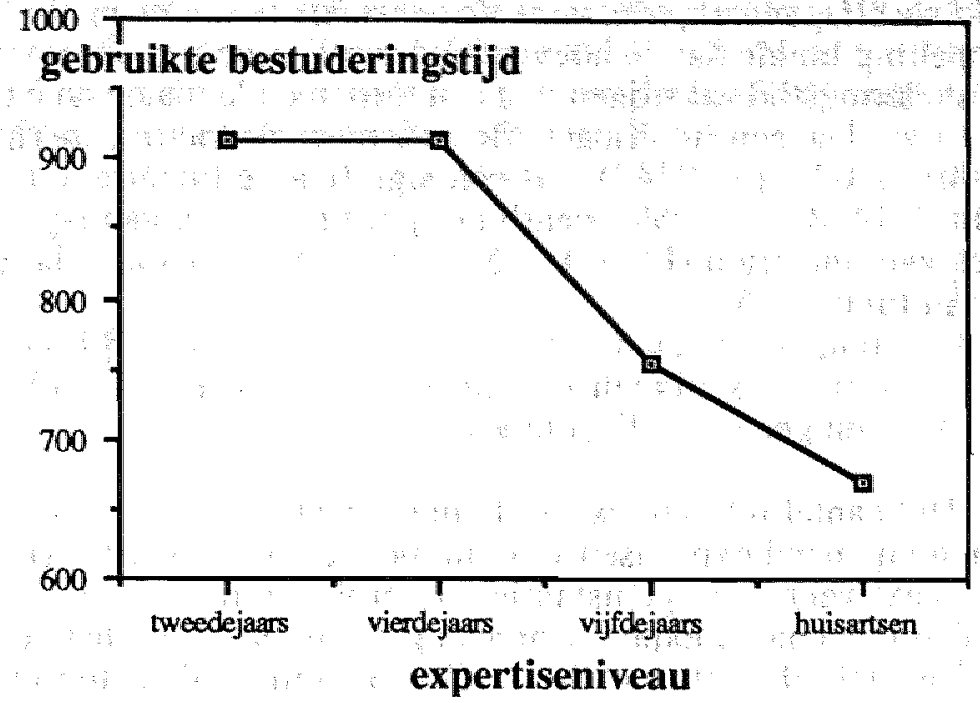

Figuur 2.4 Gebruikte bestuderingstijd uitgedrukt in seconden.

Nadere analyse toont echter aan dat er een significant verschil bestaat tussen de groepen met de minste ervaring en de twee groepen met de meeste ervaring $(F(1,62)=34.589, p=.0361)$. De jongerejaars studenten blijken gemiddeld ongeveer 200 seconden meer tijd gebruikt te hebben.

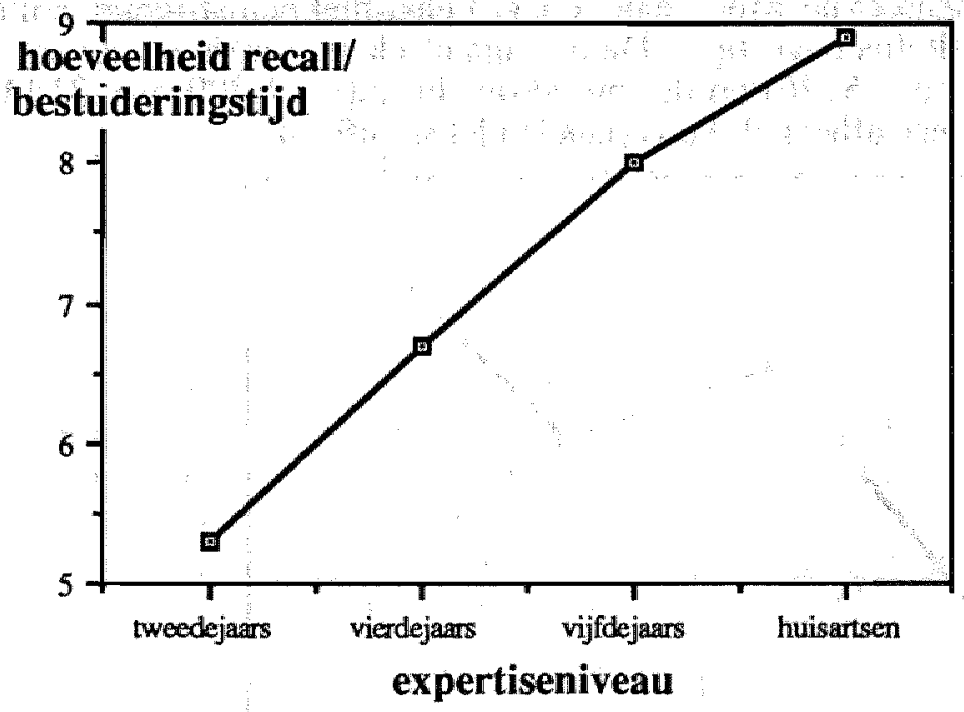

Figuur 2.5 Omvang van de probleemrepresentatie, gecorrigeerd voor de gebruikte bestuderingstijd, uitgedrukt in (de hoeveelheid recall gedeeld door de bestuderingstijd) maal 100 . 
Hoeveelheid recall, gecorrigeerd voor de gebruikte bestuderingstijdDe derde voorspelling luidde dat de hoeveelheid recall gecorrigeerd voor de gebruikte bestuderingstijd zal stijgen met een toenemende mate van expertise. Deze analyse laat een significant effekt zien van de factor expertiseniveau $(F(3,60)=3.077, p=.0342)$ met een significante lineaire component $(F(1,60)=8.1428, p=.0059)$ waarbij er geen sprake is van significante deviaties van lineariteit $(F(2,60)=.5435, p=.5836)$. Deze relatie is weergegeven in Figuur 2.5.

De overige factoren, vorm van de casus $(F(1,60)=.294, p=.5894)$ en de interaktie tussen expertiseniveau en vorm van de casus $(F(3,60)=$ $.771, \mathrm{p}=.5147$ ), leveren geen significante verschillen.

Inferenties- Het aantal inferenties werd onderzocht om na te gaan of de recall bij een toenemend expertiseniveau in meer en meer wordt beïnvloed door het geaktiveerde en geïnstantieerde probleemmodel. Voorspeld werd dat een toenemend expertiseniveau gepaard zal gaan met een toename van het aantal inferenties in de recall. Variantieanalyse toonde een significante samenhang tussen expertiseniveau en het aantal geproduceerde inferenties $(F(3,60)=3.223, p=.0288)$. Verdere analyse toonde aan dat de lineaire component in dit effekt significant is $(F(1,60)=$ $7.9954, p=.0064)$ waarbij er geen significante deviaties van lineariteit optreden $(F(2,60)=.8567, p=.4381)$. De lichte teruggang in het aantal inferenties in de recall bij vijfdejaars studenten die gesuggereerd wordt door Figuur 2.6 moet dus aan het toeval worden geweten. De hypothese dat een toenemend expertiseniveau gepaard gaat met een stijgend aantal inferenties wordt dus bevestigd. De overige effekten, vorm van de casus $(F(1,69)=.322, p=.5726)$ en de interaktie $(F(3,60)=1.209, p=.3142)$, bleken ook bij deze afhankelijke variabele niet significant.

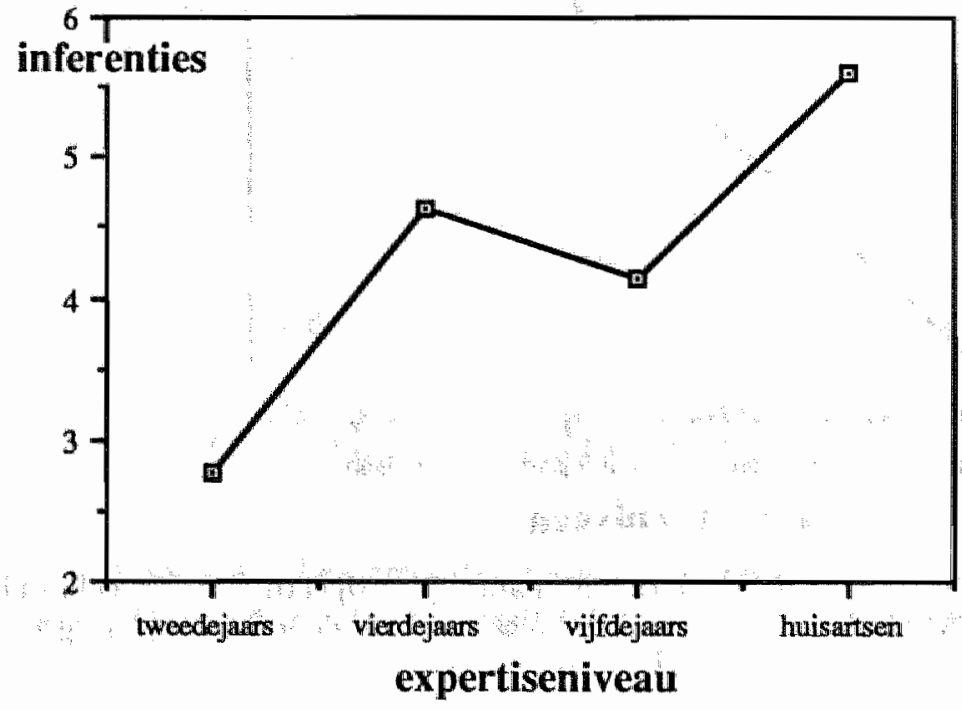

Figuur 2.6 Aantal inferenties in de recall. 
Mate van clustering-Verder werd verondersteld dat het toenemend gebruik van het geaktiveerde en geïnstantieerde probleemmodel bij de recall tot uitdrukking zou komen in een toenemende mate van clustering in de recall volgens een patiëntpresentatieschema.

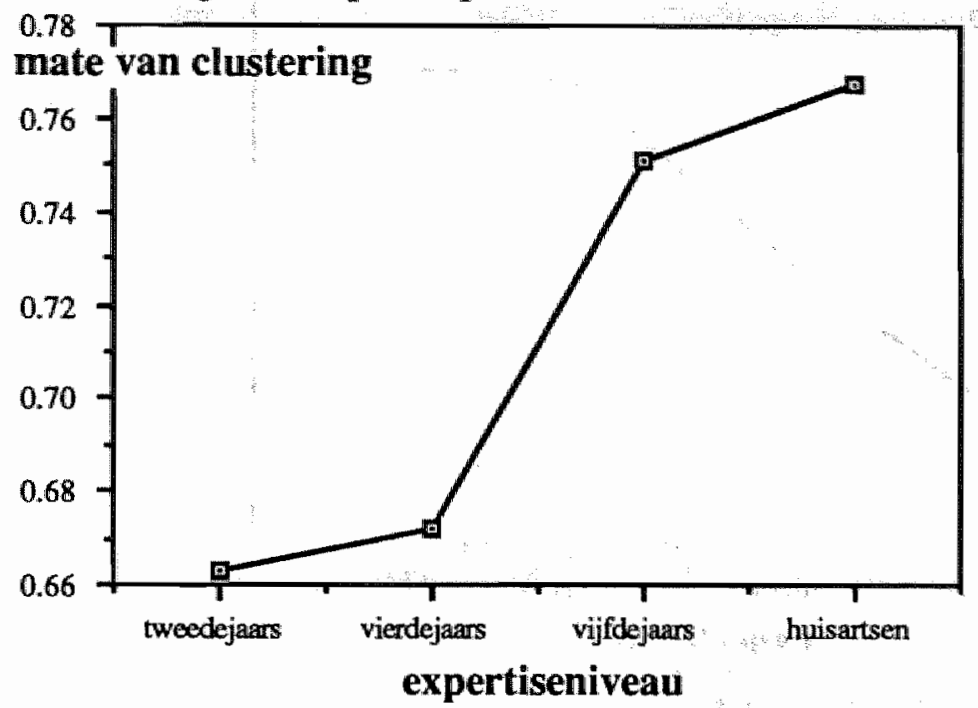

Figuur 2.7 Mate van clustering in de recall, uitgedrukt in de ARC-score (theoretisch minimum $=0$, theoretisch maximum $=1$ ).

Ook deze voorspelling wordt door de data bevestigd. Expertiseniveau blijkt significant samen te hangen met de mate van clustering $(F(3,60)=$ $2.992, \mathrm{p}=.0379$ ). De lineaire component in dit effekt blijkt significant te zijn $(F(1,60)=6.6430, p=.0124)$, terwijl er geen sprake is van significante afwijkingen van lineariteit $(F(2,60)=1.1660, p=.3186)$. Figuur 2.7 illustreert de veronderstelde monotone toename.De overige effekten zijn niet significant: vorm van de casus $(F(1,60)=1.825, p=.1818)$ en interaktie $(\mathrm{F}(3,60)=1.386, \mathrm{p}=.2558)$.

Diagnostische accuratesse- Naast de genoemde verschillen in probleemrepresentatie blijkt ook de kwaliteit van de uitkomst van het probleemoplossingsproces, de diagnostische accuratesse, samen te hangen met het expertiseniveau van de proefpersonen $(F(3,60)=19.777, p=$ $.000)$. We voorspelden daarbij dat de diagnostische accuratesse zou toenemen met een een toenemend expertiseniveau. Dat blijkt ook het geval te zijn: de lineaire component in het gevonden effekt blijkt significant $(F(1,60)=43.2456, p \leq .0001)$, maar daarbij is sprake van significante afwijkingen van lineariteit $(F(2,60)=8.4026, p=.0008)$. De lineaire component is echter groter dan de kwadratische component $(F(1,60)=$ 12.3753, $\mathrm{p}=.0008)$ en dan de derde machtscomponent $(\mathrm{F}(2,60)=$ $3.7100, \mathrm{p}=.0588$ ). Daarom mogen we concluderen dat er sprake is van een continue toename van de diagnostische accuratesse met een toenemend expertiseniveau (zie Figuur 2.8). 
De vorm van de casus, typisch of atypisch, blijkt daarbij niet uit te maken $(F(1,60)=2,465, p=.122)$. Ook is er geen sprake van interaktie tussen beide factoren $(\mathrm{F}(3,60)=.365, \mathrm{p}=.778)$.

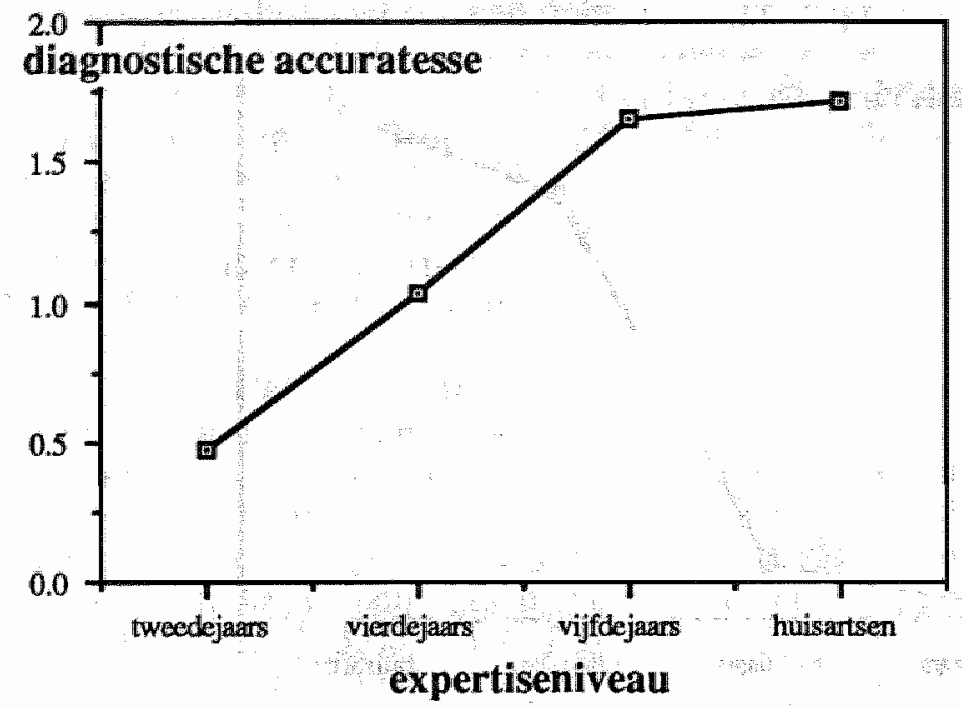

Figuur $2.8 \mathrm{~K}$ waliteit van de diagnose.

Samenhang tussen de variabelen- Om een indruk te krijgen van de samenhang van de hiervoor onderzochte variabelen zijn hun onderlinge correlaties berekend (zie Tabel 2.2). Deze product-moment correlaties zijn een maat voor de lineaire samenhang tussen de variabelen. Zoals we hiervoor hebben gezien, hebben een aantal van deze variabelen geen strikt lineaire correlatie met elkaar, zodat de gerapporteerde waarden onderschattingen zijn van het werkelijke verband tussen de variabelen. Uit deze tabel blijkt het expertiseniveau ${ }^{9}$ significant samenhangt met de tijd die gebruikt werd om de casus te bestuderen, in die zin, dat een toenemende mate van expertise gepaard gaat met een afname van de bestuderingstijd. Verder is er sprake van een positieve samenhang met de hoeveelheid recall gecorrigeerd voor bestuderingstijd, met het aantal inferenties, de mate van clustering en de kwaliteit van de diagnose. De ongecorrigeerde hoeveelheid recall blijkt samen te hangen met de de mate van clustering in de recall en met de diagnose, terwijl de gebruikte bestuderingstijd een negatief verband vertoont met de kwaliteit van de diagnose: hoe meer tijd ér gebruikt werd, hoe lager de diagnostische accuratesse. De hoeveelheid recall, gecorrigeerd voor de gebruikte bestuderingstijd, vertoont een positief verband met de mate van clustering en de diagnostische accuratesse. Ook

\footnotetext{
9 Hierbij moet worden aangetekend dat de hoogste waarde van de de variabele 'expertiseniveau' de stelwaarde ' 9 heeft meegekregen, zijnde 6 jaar medische opleiding, 1 jaar huisartsenopleiding en nog 2 jaar voor de praktische ervaring daarna. Het feitelijk aantal jaren ervaring van de huisarts-proefpersonen was niet bekend, maar ligt vermoedelijk een aantal jaren hoger.
} 
het aantal inferenties vertoont een positieve samenhang met de diagnostische accuratesse.

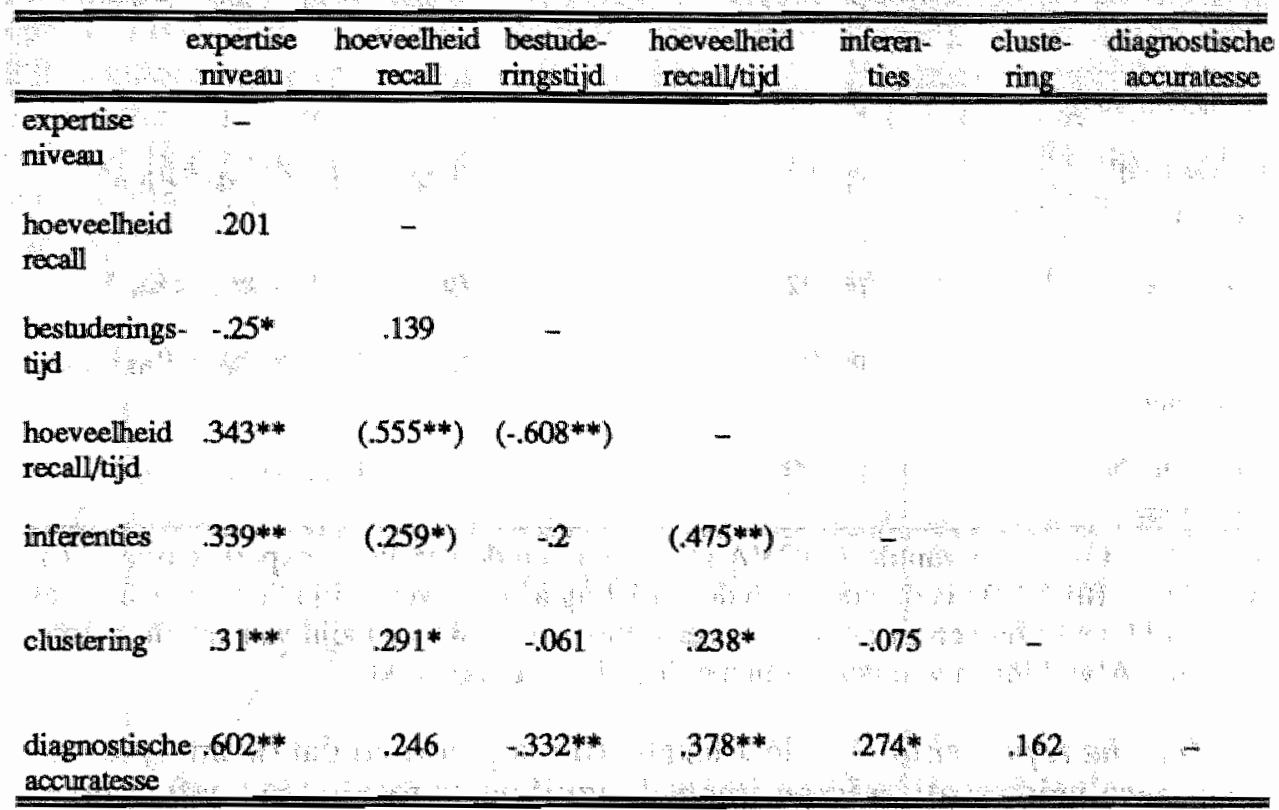

Tabel 2.2 Correlaties van expertiseniveau, de verschillende post hoc maten en de kwaliteit van de diagnose. Correlaties tussen maten die computationeel afhankelijk zijn, werden tussen haakjes geplaatst. ${ }^{*}=\mathrm{p} \leq, 05 ;{ }^{* *}=\mathrm{p} \leq .01$ éénzijdig.

\section{Discussie}

In de voorafgaande paragrafen zijn een zestal voorspellingen getoetst over de aard en de omvang van de interne representatie van een casus en over de uitkomst van het diagnostisch proces. In deze paragraaf zullen we ze in hun samenhang bespreken. Ter ondersteuning van die bespreking zijn de resultaten van de verschillende anayses bij elkaar gezet in Tabel 2.3.

De onderzochte variabelen zijn in een drietal groepen te onderscheiden. De hoeveelheid recall, de mate van clustering en het aantal inferenties hebben betrekking op de aard en de omvang van de interne representatie. De bestuderingstijd en de de hoeveelheid recall, gecorrigeerd voor de hoeveelheid bestuderingstijd hebben betrekking op de snelheid waarmee deze interne representatie tot stand is gekomen en daarmee met de mate van top down verwerking van de casus. De diagnostische accuratesse tenslotte heeft betrekking op de uitkomst van het probleemoplossingsproces. Deze drie onderwerpen stellen we achtereenvolgens aan de orde, waarna we de consequenties van de gevonden resultaten voor de geformuleerde theorie zullen bespreken. 


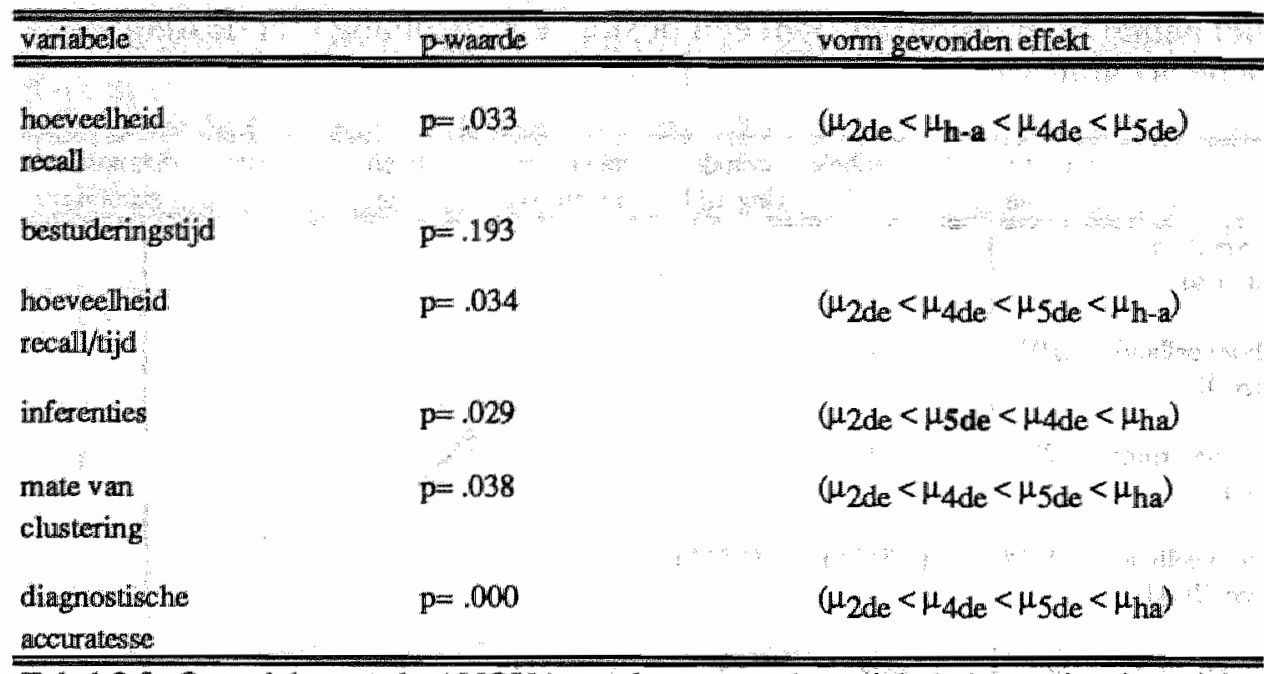

Tabel 2.3 Overzicht van de ANOVA resultaten van de variabele 'expertiseniveau' (pwaarden). $\mathrm{Bij} \mathrm{p} \leq .05$ is de vorm van de verdeling aangegeven. Bij alle variabelen was voorspeld dat er bij een toenemend expertiseniveau sprake zou zijn van een monotone stijging. Afwijkingen van deze voorspelling zijn vet afgedrukt.

Interne representatie- Geconstateerd mag worden dat de analyse van de hoeveelheid recall in Experiment 1 significante resultaten heeft opgeleverd. Dit resultaat maakt aannemelijk dat de oorzaak van het feit dat in zes van de tien eerder besproken recallstudies geen verschillen in hoeveelheid recall werden gevonden, gelegen is in een weinig robuust effekt. Dat wil zeggen dat in deze onderzoekingen relatief gesproken te weinig proefpersonen zijn gebruikt om verschillen in de recall van een casus te kunnen aantonen die samenhangen met een toenemend expertiseniveau.

Helaas moeten we constateren dat de voorspelde vorm van de verdeling niet gevonden werd. Verwacht werd een continue stijging van de hoeveelheid recall. Deze stijging zou niet over het hele trajekt van de curve even groot zijn. Verwacht werd dat de hoeveelheid recall zou naderen tot een asymptoot, maar we verwachtten in geen geval een teruggang in de recall bij de meest ervaren groep. En dit verschijnsel bleek juist wel op te treden.

Dit verschijnsel behoeft een nadere analyse. Daartoe gaan we terug naar de theorie die aan deze voorspelling ten grondslag ligt. De hoeveelheid recall is opgebouwd uit de recall van de individuele proposities van de casus en de inferenties die deze proposities overstijgen. De recall van de individuele proposities wordt in deze theorie voorspeld uit een toenemende volledigheid en coherentie van de textbase. De volledigheid van de textbase wordt in onze redenering uitsluitend beïnvloed door de bekendheid met de gebruikte terminologie. Een toenemende coherentie zou samenhangen met een toenemende kennis van de macrostruktuur van een casusbeschrijving, waardoor individuele casusproposities gemakkelijker herinnerd kunnen worden. Deze twee verschijnselen samen zouden 
leiden tot een hoeveelheid recall van de casusgegevens die nadert tot een asymptoot. Daarnaast werd aangenomen dat het aantal inferenties in de recall zou toenemen. Optelling van deze effekten leidt dan tot de voorspelling dat de hoeveelheid recall een monotone stijging zal vertonen bij een toenemend expertiseniveau. In Figuur 2.9 is weergegeven hoe in Experiment 1 de recall van de oorspronkelijke proposities en de inferenties optellen tot de totale hoeveelheid recall. We zien daarin dat de recall van de individuele casusproposities zich in het geheel niet gedraagt zoals voorspeld werd. De curve nadert niet tot een horizontale asymptoot: Integendeel, na het vijfde jaar is er duidelijk sprake van een daling.

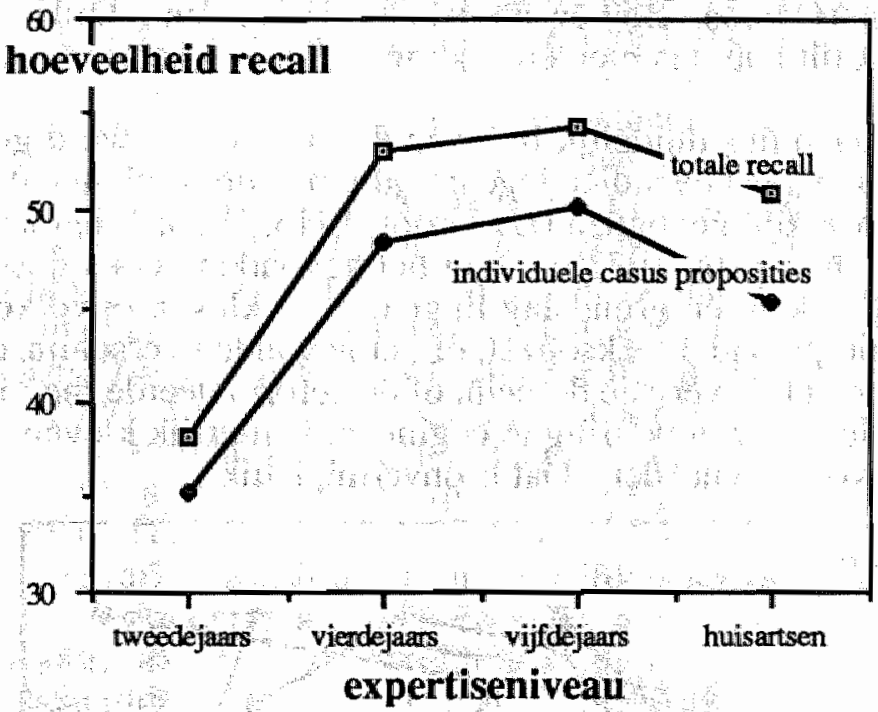

Figuur 2.9 Componenten van de hoeveelheid recall. In deze figuur zijn de totale hoeveelheid recall en de recall van de individuele casusproposities weergegeven. Het verschil tussen deze curves is de hoeveelheid inferenties in de verschillende groepen, die ook apart is weergegeven in Figuur 2.6.

Vijfdejaars studenten reproduceren meer casusproposities dan vierdejaars studenten en dan huisartsen. De tweedejaars studenten reproduceren het geringste aantal proposities. Variantieanalyse toont aan dat de intermediates hoger scoren dan de beginners en de experts $(F(1,6)=3.914$, $p=$ .0523). De toename in het aantal inferenties is onvoldoende om deze daling te compenseren.

Wel bleek dat de samenhang in de textbase, gemeten met behulp van de clusteringsscore, steeg met een toenemend expertiseniveau. Dit betekent dus dat men met een toenemend expertiseniveau meer en meer geneigd is een casus volgens een patiëntpresentatieschema te reproduceren. Volgens Van Dijk en Kintsch (1983) zou zo'n meer samenhangende textbase beter worden gereproduceerd, hetgeen dus niet door de data wordt ondersteund. Deze overweging levert extra evidentie voor de conclusie dat de omvang van de interne representatie niet, zoals voorspeld, met een toenemend expertiseniveau stijgt over het gehele trajekt van expertise- 
groei. De gegevens wijzen er duidelijk op dat na een zeker moment in de expertiseontwikkeling een vermindering van de omvang van de interne representatie optreedt.

Dit effekt is des te onverwachter als we bedenken dat een toenemend expertiseniveau gepaard gaat met een uitgebreider en beter toegankelijk kennisbestand, waardoor experts sneller over een beter probleemmodel kunnen beschikken dan de andere proefpersonen. Dit probleemmodel heeft niet alleen een funktie tijdens de encodering, hetgeen leidt tot een groter aantal inferenties in de recall en tot een betere diagnose. Het probleemmodel kan ook gebruilkt worden als een 'reproduktie-generator' van de casusproposities (Owens, Bower en Black, 1979; Van Dijk en Kintsch, 1983). Ook dit zou dus moeten bijdragen aan een betere recall van de casus.

Deze resultaten gaan dus duidelijk in tegen de theorie, die werd geformuleerd. Het resultaat is bovendien tegenstrijdig met de resultaten die in het schaakonderzoek zijn gevonden (De Groot, 1946, 1965; Jongman, 1968; Chase en Simon, 1973a, 1973b). Aan het gevonden verschijnsel kunnen meerdere oorzaken ten grondslag liggen: óf er kleven onvolkomenheden aan de huidige onderzoeksopzet, of het gevonden verschijnsel is eigen aan het onderzochte, verbale domein, of de geformuleerde theorie is onjuist. Om met de eerste verklaring te beginnen: natuurlijk kleven er aan dit onderzoek onvolkomenheden. Dat is onvermijdelijk.

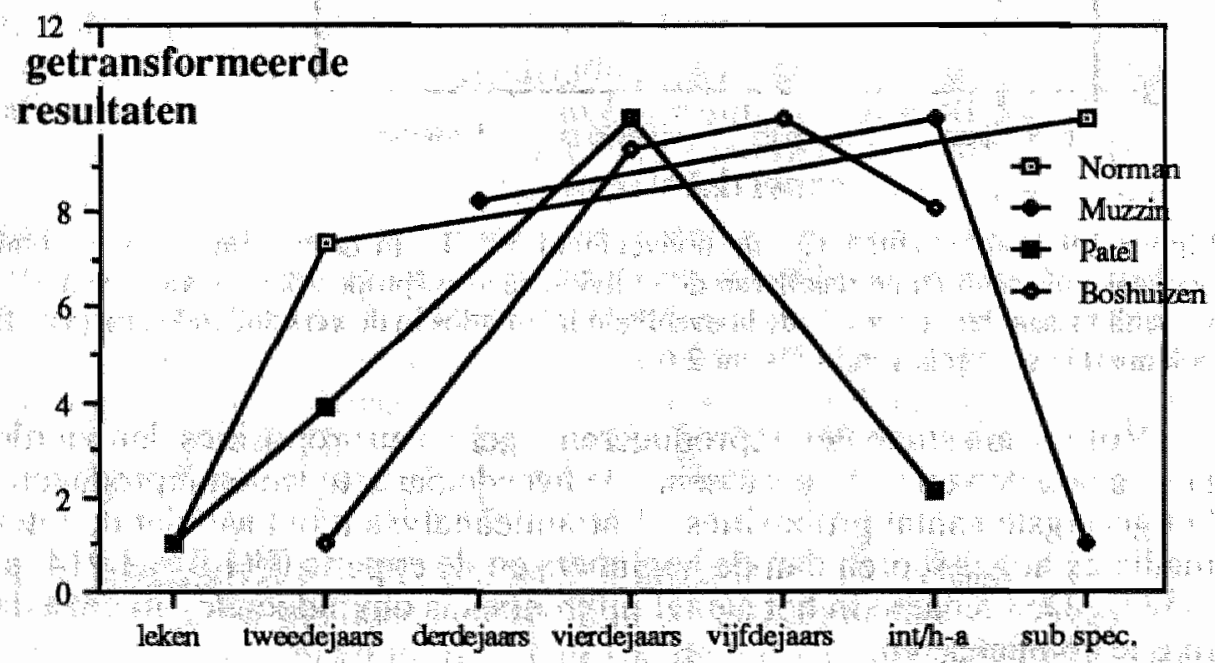

\section{expertiseniveau}

Figuur 2,10 De resultaten van 4 recallstudies bij elkaar gebracht na lineaire transformatic naar een schaal van 1 (overeenkomend met het laagste groepsgermiddelde) tot 10 (voor het hoogste groepsgemiddelde).

Het is echter wel opvallend dat twee van de drie onderzoekingen die eerder in dit hoofdstuk werden besproken, ook een dergelijke relatie tussen expertiseniveau en recall vertonen. De resultaten van deze drie onderzoekingen en die van Experiment 1 zijn (na transformatie naar een 
schaal lopend van $1-10$ ) in Figuur 2.10 bij elkaar gebracht 10 . Dit beeld suggereert dat de gevonden recallresultaten eigen zijn aan het domein van onderzoek en niet berusten op een artefakt. Dit betekent dus dat de theorie op grond waarvan we tot onze voorspellingen kwamen, moet worden bijgesteld. De punten waarop die bijstelling moet plaatsvinden, komen in de laatste paragraaf van dit hoofdstuk aan de orde.

Representatiesnelheid-Een toenemende rol van het probleemmodel bij het construeren van de interne representatie heeft als gevolg dat de verwerking van binnenkomende informatie veel meer een top down karakter krijgt. Deze toenemende top down verwerking zou op twee wijzen tot uitdrukking moeten komen: 1) in de tijd die iemand nodig heeft om de interne representatie op te bouwen (een toenemend expertiseniveau zou dus gepaard gaan met een afnemende bestuderingstijd) en 2) in de representatiesnelheid (een toenemend expertiseniveau zou gepaard gaan met een toenemend aantal proposities dat per seconde bestuderingstijd wordt gerepresenteerd (Spiro, 1980)). De voorspelling dat de representatiesnelheid (de hoeveelheid juiste recall gedeeld door de gebruikte bestuderingstijd) zou toenemen met een toenemend expertiseniveau werd volledig bevestigd, De voorspelling dat er een afnemende bestuderingstijd gevonden zou worden, werd echter niet bevestigd.

Dit laatste resultaat wordt echter genuanceerd door een aantal bevindingen. Ten eerste bleken de verschillen tussen de groepen met praktische ervaring (de huisartsen en vijfdejaars studenten) enerzijds en de groepen zonder praktische ervaring anderzijds wel significant te zijn. Verder valt op dat de spreiding in de twee minst ervaren groepen (de standaarddeviaties bedragen respectievelijk 868.5 en 996.6 seconden) veel groter is dan in de twee andere ( 554.5 en 502.0 seconden). Bovendien blijkt uit de polynoomanalyse dat de lineaire component wel significant is $(F(1,60)=4.0429, p=.0489)$, waarbij geen significante afwijkingen van lineariteit optreden $(\mathrm{F}(2,60)=.4137, \mathrm{p}=.6631)$. Deze bevindingen tezamen suggereren een afnemende bestuderingstijd bij een toenemend expertiseniveau, een trend die echter onder druk staat van grote individuele verschillen in bestuderingstijd bij de jongerejaars groepen.

Typische en atypische casus-Verwacht werd dat de aktivatie van een passend probleemmodel moeilijker zal zijn bij een atypische casus dan bij een typische casus. De vorm van de casus zou dus van invloed zijn op het aantal inferenties en op de bestuderingstijd. Het zou ook tot uitdrukking kunnen komen in de kwaliteit van de diagnose. Geen verschillen werden verwacht in de resulterende textbase: noch in de hoeveelheid recall, noch in de mate van clustering. De resultaten laten echter geen enkel effekt zien van de vorm van de voorgelegde casus: alle p-waarden zijn

10 Het laagste gemiddelde van ieder onderzoek is getransformeerd naar 1 , het hoogste naar 10. De tussenliggende waarden zijn via een lineaire transformatie bepaald. 
hoog. Dit geldt zowel voor het hoofdeffekt van de vorm van de casus als voor de interaktie met het expertiseniveau. Het merendeel van deze pwaarden is ongeveer $50 \%$. We willen hieruit echter nog niet concluderen dat een atypische casus even gemakkelijk te representeren is als een typische en dat de kenmerken van de uiteindelijke representaties ook niet van elkaar verschillen. Het betrof hier namelijk een onderzoek met een vrije bestuderingstijd, die leidde tot grote binnen-groepen-variantie, die alleen het gevolg was van systematische verschillen tussen proefpersonen. Het is daardoor zeer wel mogelijk dat relatief kleine effekten ten gevolge van het type casus verloren zijn gegaan in verschillen, die een gevolg zijn van verschillen in bestuderingstijd.

De conclusies die we tot zo ver hebben geformuleerd, kunnen als volgt worden samengevat:

a) Meer ervaren proefpersonen gebruiken minder tijd om een casus te representeren.

b) De samenhang van de interne representatie verbetert met een toenemend expertiseniveau.

c) Toch vertoont de hoeveelheid recall die op basis van deze interne representatie tot stand komt eerder een omgekeerd $U$-vormig verband met het expertiseniveau dan een monotoon stijgend verband.

d) De toenemende rol van het probleemmodel in de probleemrepresentatie komt tot uitdrukking in een toenemend aantal inferenties en in een betere diagnose.

De interne representatie die experts van een casus opbouwen, is dus misschien minder omvangrijk (in termen van het aantal oorspronkelijke casusproposities dat in de representatie is opgenomen). Daar staat echter een grotere funktionaliteit in het probleemoplossingsproces tegenover, getuige de toenemende diagnostische accuratesse. Blijkbaar representeren de experts de casus op een andere wijze dan de minder ervaren proefpersonen dat doen.

\section{ALGeMENE DISCUSSIE}

De resultaten van dit onderzoek zijn zeer intrigerend. Onderzoekers in andere domeinen van expertise zoals schaken (De Groot, 1946, 1965; Jongman, 1968; Chase en Simon, 1973a, 1973b), go (Reitman, 1976), telegrafie (Bryan en Harter, 1899) en hoofdrekenen (Hunter, 1962; Müller, 1911) en baseball (Spilich, Vesonder, Chiesi en Voss, 1979) laten wel een toename van de hoeveelheid recall zien. Wij hebben echter aanwijzingen gevonden, dat de gevonden omgekeerd U-vormige relatie tussen hoeveelheid recall en mate van expertise vermoedelijk een gevolg is van kenmerken van het domein. Dit effekt zou door twee processen veroorzaakt kunnen zijn: a) door selektie en b) door chunking. Beide processen zouden in het medisch-verbale domein een andere uitwerking kunnen hebben dan in een non-verbaal domein. 
Vergelijken we een medische casus met een schaakstelling, dan valt op dat een medische casus informatie bevat, die relevant is gezien de aandoening van de patiënt en informatie, die gezien de huidige klacht niet relevant is. Met een schaakstelling is dat anders. Ieder stuk heeft zijn funktie in het geheel, en zou er éen worden weggehaald, dan verandert daardoor de gehele stelling. In de telegrafie geldt hetzelfde. Ieder stippeltje en ieder streepje is even belangrijk. Een selektieproces, zoals dat werkzaam zou kunnen zijn bij medische experts (Patel en Frederiksen, 1984, Patel en Medley-Mark, 1986) zal bij het representeren van informatie in deze domeinen veel minder op de voorgrond kunnen treden.

Chunking van informatie zal in alle domeinen van expertise optreden (Jongman (1965) wijt zelfs de fenomenale recall van schaakexperts aan grotere chunks). Het heeft echter in een verbaal domein een andere uitwerking dan in een non-verbaal domein. De chunk hoofdstelling van het gesloten Spaans' betekent niets anders dan dat de witte stukken zich op de volgende velden bevinden: Toren a1; Paard b1; Loper c1; Dame d1; Toren e1; Koning g1; Loper c2; Paard f3; en pionnen op a2, b2, c3, d4, e4, f2, g2 en h3, terwijl de zwarte stukken zich bevinden op de velden: Toren a8; Loper c8; Toren 18; Koning g8; Dame c7; Loper e7; Paard f6; Paard a5; en pionnen op a6, b5, c5, d6, e5, f7, g7 en h7. Dit maakt het voor een schaker heel eenvoudig om een dergelijke stelling zonder veel fouten terug op het bord te plaatsen. In de geneeskunde ligt het anders. De chunk 'RT: g.b.' kan op allerlei mogelijk variaties duiden: min of meer normale bevindingen of meer of minder lichte afwijkingen van normaliteit die in het licht van de huidige klacht geen betekenis hebben. Het is in feite een goede samenvatting van de toucher-bevindingen in de atypische prostatitiscasus (zie Bijlage 2). Uit een dergelijke chunk zijn de constituerende elementen veel moeilijker te reconstrueren. Er moet in ieder geval iets van onthouden zijn. Een andere expert die deze informatie niet kent, zal hiertoe niet in staat zijn, in tegenstelling tot een schaakmeester die de chunk "hoofdstelling van het gesloten Spaans' krijgt voorgelegd.

In één chunk kan dus een grote hoeveelheid informatie (casusproposities) worden samengevat. Toenemende expertise gaat in ons onderzoek gepaard met een toenemend aantal inferenties: chunks, omdat het inferenties betreft die gebaseerd zijn op meerdere proposities. Hoeveel informatie voor een persoon in één chunk is bevat, is echter niet te zeggen. Hierdoor is het dus onmogelijk een kwantificatie te maken van de hoeveelheid informatie die eigenlijk in de interne representatie is opgenomen en is onze hoeveelheid recall een onderschatting van de eigenlijke omvang van de interne representatie.

Al met al kunnen we zeggen dat Experiment 1 laat zien dat een toenemende medische expertise in de eerdere stadia van de ontwikkeling gepaard gaat met een toenemende omvang van de interne representatie, die later gekenmerkt wordt door een betere integratie en samenhang en vermoedelijk door een betere selektie van relevante informatie, terwijl de representatie bovendien sneller tot stand komt. De indruk is dan ook ge- 
rechtvaardigd dat er tijdens de ontwikkeling tot expert in de geneeskunde meerdere leerprocessen werkzaam zijn. Om hier meer inzicht in te krijgen, is het echter noodzakelijk ook de ontwikkeling van de kennis, die bij de probleemrepresentatie gebruikt wordt in het onderzoek te betrekken. In het volgende hoofdstuk zal een onderzoek worden gepresenteerd, dat speciaal hierop is gericht. 


\section{HOOFDSTUK 3}

\section{STADIA IN DE KENNISONTWIKKELING 1}

\section{INLEIDING}

In dit proefschrift zijn we geinteresseerd in de veranderingen in iemands kennis die optreden in de loop van diens ontwikkeling tot expert in de geneeskunde. Met Experiment 1 is een eerste stap gedaan om te achterhalen welke processen een rol spelen bij de ontwikkeling van die kennis. Dit werd gedaan door middel van onderzoek van de interne representatie van een casus, die opgebouwd wordt door proefpersonen met verschillend expertiseniveau. Daarbij werd een post hoc methode gebruikt. De belangrijkste bevinding daarbij was dat er geen monotone relatie lijkt te bestaan tussen mate van expertise en de hoeveelheid proposities die men zich van de casus kan herinneren. Een ander belangrijk verschijnsel betreft de bestuderingstijd. Jongerejaars studenten bleken meer tijd te gebruiken om de casus te bestuderen dan ouderejaars studenten en artsen. Verder was er

\footnotetext{
${ }^{1}$ Een deel van de resultaten die in dit hoofdstuk worden gepresenteerd, is gepubliccerd in Schmidt, H.G., Boshuizen, H.P.A en Hobus, P.P.M. (1988), Transitory stages in the development of medical expertise: the "Intermediate Effect in clinical case representation studies. In: Proceedings of the Tenth Annual Conference of the Cognitive Science Society. Hillsdale NJ: Erlbaum.
} 
sprake van een toenemend aantal inferenties in de recall en van een toenemende samenhang. We concludeerden hieruit dat een eenvoudig model, dat een rechtstreekse relatie veronderstelt tussen toenemende expertise, toenemende kennis en de aard van de interne representatie geen geldigheid heeft.

Maar hoe zou die relatie dan wel kunnen zijn? Een toenemende representatiesnelheid, sterkere selektie van casusproposities en een grotere mate van chunking wijzen er alle op dat het probleemmodel een steeds belangrijkere rol gaat spelen in de verwerking van de casus, maar daarmee is nog niets gezegd over de kennis, waaraan dit probleemmodel is ontleend. Misschien is daar toch op grond van de nu voor handen zijnde gegevens iets meer over te zeggen. De curvilineaire relatie tussen hoeveelheid recall en mate van expertise wijst erop dat er tijdens het eerste deel van het ontwikkelingstrajekt sprake is van toename van kennis. In het volgende trajekt gaat echter een ander verschijnsel overheersen. De afname van de hoeveelheid recall, wijzend op een grotere selektie van de patiëntgegevens en het toenemende aantal inferenties, hetgeen wijst op een grotere hoeveelheid chunks in de recall, suggereert dat er een stadium is bereikt waarin de informatie op een andere, meer top down wijze kan worden verwerkt. Systematische veranderingen in de kennis hebben hiertoe aanleiding gegeven. Ook het feit dat de juistheid van de gestelde diagnose toeneemt met een stijgend expertiseniveau wijst hierop.

Dit idee van twee afzonderlijke stadia in het ontwikkelingsproces naar expertise sluit goed aan bij de theorieën over de ontwikkeling van expertise, die in Hoofdstuk 1 werden besproken. Globaal gesproken kan de eerste fase van leren worden gekarakteriseerd door toename van de kennis. In die fase zijn perioden aan te wijzen waarin de verworven kennis wordt geherstruktureerd. Het herstruktureringsproces zelf heeft niet als resultaat dat er een toename van de kennis plaatsvindt, maar een beter begrijpen. Hierdoor verbetert de samenhang in het kennisbestand en dit laatste kan een noodzakelijke voorwaarde zijn daarna weer nieuwe kennis op te kunnen doen. Piagets perioden van assimilatie en accomodatie zijn hiermee vergelijkbaar (Piaget en Inhelder, 1968). Deze eerste fase van het leerproces duidden we aan met 'kennisaccumulatie'. Nadat op deze wijze een voldoende hoeveelheid, samenhangende kennis is verworven, treedt een nieuwe fase in waarin de kennis meer en meer gebruiksgeschikt wordt gemaakt ${ }^{2}$. In deze fase, die we in navolging van Norman en Rumelhart

2 We gaan hier niet in op de technische bijzonderheden van dat proces. De processen die door de verschillende auteurs verondersteld worden werkzaam te zijn, hangen nauw samen met het gebruikte representatiemodel. Anderson (1983) veronderstelt dat de kennis in de cognitieve fase declaratief van aard is en representeert dit als een propositioneel netwerk. Daarna wordt de kennis geproceduraliseerd en wordt een bestand van produktieregels opgebouwd. Rumelhart en Norman (1978) nemen aan dat de kennis in alle fasen van het leerproces gerepresenteerd is in de vorm van schema's, terwijl Laird, Rosenbloom en Newell (1986) in hun SOAR-systeem een representatie met produktieregels gebruiken. 
(1978) de 'afstemmingsfase' (tuning) noemen, worden lange zoekpaden verkort en raakt de algemene kennis gespecialiseerd. Anderson (1983) noemt het leerproces dat hier plaatsvindt, compilatie'. Het eerder geelaboreerde kennisbestand wordt in deze fase van het ontwikkelingsproces gecompileerd.

Probleemoplossen en dus ook medische diagnostiek zal, naar we vermoeden, in deze twee stadia op verschillende wijzen verlopen. We nemen aan dat in het stadium van kennisaccumulatie de relevante kennis nog niet geheel automatisch wordt geaktiveerd door het probleem en door de omstandigheden waarin het probleem zich aandient. De student zal dus moeten teruggrijpen op heuristieken (zoals means-ends-analysis) om zo te trachten het probleem al redenerend op te lossen (Anderson, 1973; Laird, Rosenbloom en Newell, 1986). Hierbij zal hij geëlaboreerde kennis aktief moeten toepassen. Wanneer de kennis eenmaal voldoende gecompileerd is, dan is al dat bewust redeneren niet nodig. Nu is de relevante kennis als het ware in éen keer automatisch beschikbaar.

Het volgende voorbeeld vormt hiervan een illustratie. Het betreft de kennis van een vierdejaars student geneeskunde over het onderwerp 'hartinfarct'. Dit deel van de kennis is natuurlijk niet geïsoleerd. De student heeft ook kennis over andere hartafwijkingen en aandoeningen in de borst zoals long-en slokdarmaandoeningen. Deze kennisonderdelen hangen met elkaar samen, bijvoorbeeld doordat de verschillende aandoeningen een aantal symptomen of andere elementen met elkaar gemeen hebben (zie Figuur 3.1).

Wordt nu zo'n student geconfronteerd met een mannelijke patiënt van 55 jaar, met een overgewicht van ongeveer 10 kilo, van wie bekend is dat hij een pakje sigaretten per dag rookt en die telefonisch klaagt over pijn achter het borstbeen, die een kwartier geleden begonnen is, dan wordt door deze gegevens een aantal concepten in het netwerk geaktiveerd. Zowel 'roken' als 'pijn' als "duur: langer dan 15 minuten' worden geaktiveerd en de aktiviteit verspreidt zich van daaruit over het netwerk. Aktivatie van 'roken' en de 'pijn' leidt zowel tot aktivatie van 'acute ischemie van het myocard' als van 'infarcering' en 'hartinfarct'. De duur van de pijn leidt alleen tot aktivatie van het conceptenpaar 'hartinfarct' en 'infarcering'. Doordat alle aktivatie bij elkaar wordt opgeteld, worden de concepten 'infarcering' en 'hartinfarct' het meest geaktiveerd (Anderson, 1983). Deze komen dus als hypothese het meest op de voorgrond te staan.

Op deze manier beschreven zou het stellen van een hypothese, ook in de accumulatiefase, een automatisch proces zijn. Aktivatie van het ene concept leidt automatisch tot aktivatie van het andere.

De keuze van een representatiesysteem is in zekere zin arbitrair. Declaratieve kennis kan als procedurele kennis worden geschreven en produktieregels kunnen worden omgezet in proposities. Aangezien dit proefschrift zich uitsluitend met de menselijke kennisverwerving bezighoudt en de mogelijkheid van een computersimulatie niet wordt nagestreefd, is het niet nodig hierin een keuze te maken. 


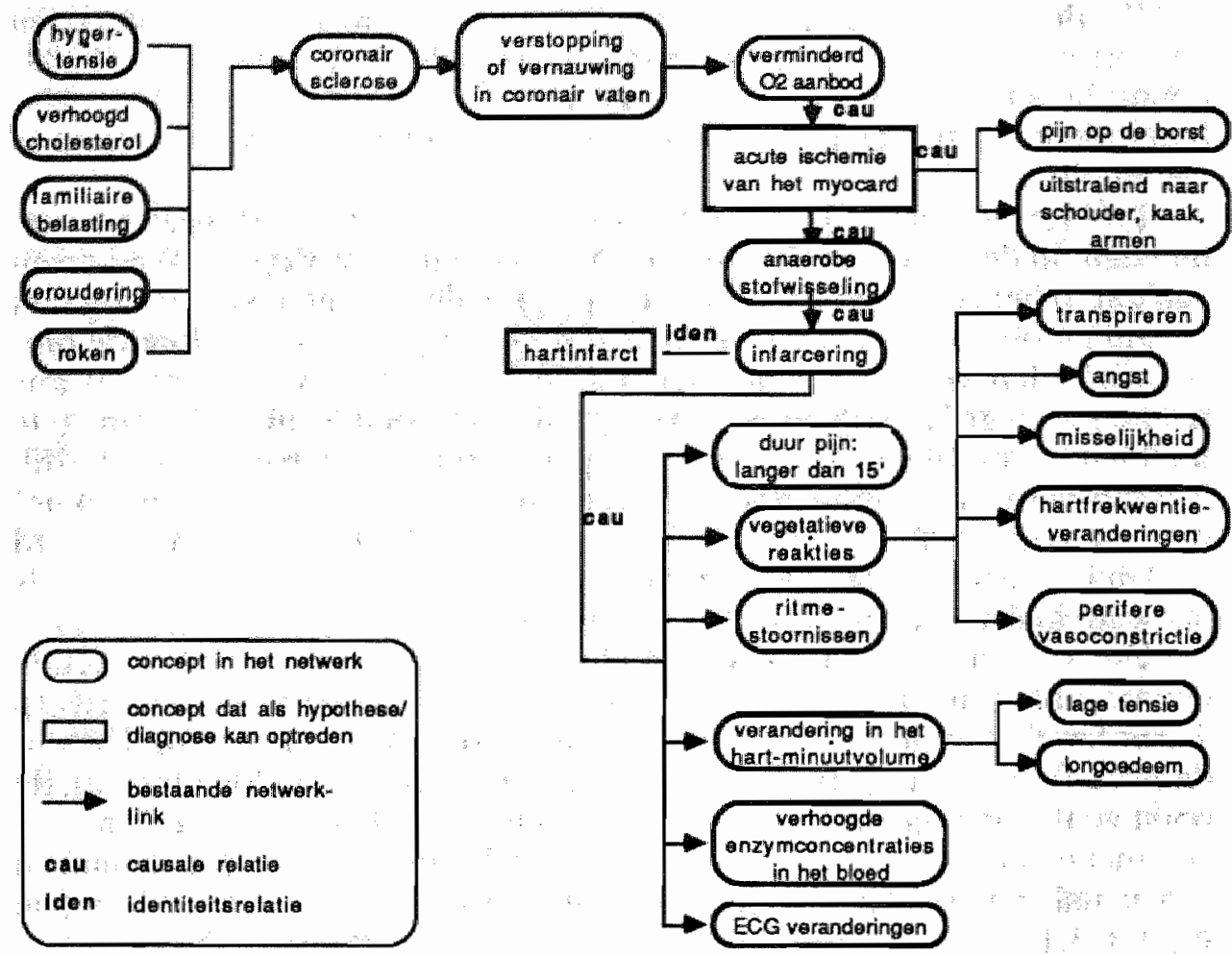

Figuur 3,1 Semantisch netwerk dat een deel van de kennis van een hypothetische vierdejaars student in de geneeskunde beschrijft. Dit deel is verbonden met andere kennis over anatomische strukturen, aandoeningen en (patho)fysiologische processen in de thorax.

Het kan echter gebeuren dat de student nooit bij het 'hartinfarct' uitkomt. Bijvoorbeeld omdat 'roken' en de 'pijn' door de student maar heel zwak met een 'hartinfarct' worden geassocieerd, of omdat 'roken' veel sterker met 'longkanker' is geassocieerd. Deze associatiesterkte wordt bepaald door het aantal keren dat twee concepten tegelijkertijd geassocieerd zijn geweest. Het kan ook zijn dat bij deze student 'pijn op de borst' met heel veel verschillende aandoeningen is geassocieerd. In alle genoemde gevallen zal de relatieve associatie met 'hartinfarct' dermate laag zijn dat andere aandoeningen op de voorgrond treden. Verder dooft aktivatie uit na verloop van tijd. In ons voorbeeld namen we aan dat het concept 'infarcering' aktivatie ontvangt vanuit drie andere concepten die door additie tot de hoogste aktivatie leidt. Dit effekt kan echter verstoord worden wanneer de aktivatie vanuit 'roken' zo lang onderweg is dat de aktivatie vanuit de beide andere concepten al weer is weggeëbd wanneer deze uiteindelijk de 'infarcering' bereikt. In zulke gevallen moet een student allerlei cognitieve aktiviteiten aan de dag leggen om toch een redenering tot stand te brengen.

Meestal zullen niet alle gegevens over de patiënt en zijn of haar klacht en symptomen rechtstreeks een concept in het netwerk aktiveren. In ons 
voorbeeld geldt dat voor de gegevens omtrent het overgewicht en de leeftijd van de patiënt. Het is dan nodig deze gegevens te bewerken voordat ze een rol kunnen spelen in de diagnostiek bij deze patiênt. Het overgewicht van de patiënt kan bijvoorbeeld via een redeneerstap als 'vet eten' aan het netwerkconcept 'verhoogd cholesterol' worden gekoppeld, van waaruit het ook leidt tot aktivatie van het concept 'hartinfarct'. Dit verschijnsel zal zeer vaak optreden.

Via de aktivatie van 'infarcering' en 'hartinfarct' worden een aantal andere concepten geaktiveerd, die de symptomen van het hartinfarct vertegenwoordigen. Deze symptomen moeten bij de patiënt middels anamnese en onderzoek worden geverifieerd alvorens tot de diagnose kan worden besloten. Op deze wijze redeneert de student zich als het ware door het kennisbestand heen (Hassebrock en Prietula, 1986) om eerst een hypothese te genereren en daarna af te leiden welke symptomen verder aanwezig zouden moeten zijn als de veronderstelde diagnose de juiste is.

Door deze kennis nu vaak toe te passen in verschillende situaties en bij patiënten met steeds weer andere kenmerken en met duidelijke variaties in het ziekteverloop, wordt de kennis meer en meer gericht op de toepassing in de praktijk, zoekpaden worden verkort en er treedt specialisatie op. 'Roken', 'pijn op de borst en die langer dan een kwartier aanhoudt' zullen direkt gekoppeld raken aan 'hartinfarct'. Verder zal er door de ervaring specialisatie optreden. Er kan bijvoorbeeld een apart kennisbestand voor mannen (ouder dan 45 jaar) en voor vrouwen (ouder dan 60 jaar) met een hartinfarct worden aangelegd.

In dit stadium van de ontwikkeling hoeft de arts of de gevorderde student ook niet meer te redeneren. Niet bij het stellen van een diagnostische hypothese en niet bij het bepalen van relevante vragen en onderzoek om de hypothese te bevestigen dan wel te ontkennen. Als eenmaal de hypothese is gesteld, dan is daarmee de kennis over symptomen en verloop van de aandoening automatisch beschikbaar.

Deze verandering in kennisstruktuur, die ontstaat onder invloed van de ervaring, kan verklaren waarom de studenten in de eerste fase van expertiseontwikkeling meer tijd nodig hebben dan experts bij het representeren van een casus. Zij moeten immers in de hierboven gevolgde redenering een uitgebreid, geëlaboreerd kennisbestand aktiveren. Bovendien zouden studenten in deze eerste fase bewust moeten redeneren, omdat de relevante verbindingen tussen kènniselementen nog niet erg sterk zijn. Verbindingen worden pas sterk, wanneer een tweetal concepten een aantal keren tegelijk geaktiveerd is geweest; dus nadat zo'n netwerk een aantal keren is doorgeredeneerd. Experts daarentegen aktiveren een gecompileerd kennisbestand, waardoor de gegevens uit de casus automatisch gekoppeld worden aan de diagnose. Op deze wijze zou ook verklaard kunnen worden waarom in Experiment 1 vijfdejaars studenten zo veel onthouden van de voorgelegde casus. Deze studenten beschikken over alle relevante basiskennis maar door hun geringe praktische ervaring kan compilatie van hun kennis nog nauwelijks hebben plaats gevonden. Door intensief re- 
deneren en elaboreren op die kennis lijken ze toch in staat te zijn een interne representatie te construeren die voldoende coherent is om tot een goede recall te komen. De kennis van de tweedejaars studenten daarentegen verkeert nog duidelijk in een opbouwfase. Gezien de hoeveelheid tijd die deze studenten gebruiken om de casusinformatie te verwerken, mogen we aannemen dat zij de casusinformatie op dezelfde wijze verwerken als de vierdejaars dat doen, maar dat ze niet genoeg relevante kennis kunnen aktiveren om voldoende coherentie in de representatie aan te brengen. $\mathrm{Na}$ het vierde studiejaar beginnen medische studenten aan hun stages in de kliniek en bij de huisarts. Als de geschetste veronderstelling juist is, dan resulteert een toenemende mate van ervaring na het vierde jaar in een toenemende compilatie van kennis waardoor zoekpaden worden verkort hetgeen resulteert in steeds kortere bestuderingstijden.

Als de processen van accumulatie van kennis en daaropvolgend compilatie daarvan inderdaad ten grondslag liggen aan verschillen in recall, die in Experiment 1 bij een toenemend expertiseniveau werden gevonden, dan moet experimentele beperking van de bestuderingstijd differentiële effekten hebben op personen met een verschillende mate van expertise. Beginners die nog weinig kennis hebben, zullen, ongeacht de hoeveelheid bestuderingstijd, niet veel kennis kunnen aktiveren waarmee zij betekenis kunnen geven aan een casusbeschrijving, die ze wordt voorgelegd. Personen met een intermediair expertiseniveau daarentegen, die bij het representeren van een casus gebruik maken van een geëlaboreerd kennisbestand, zullen bij beperking van de tijd sterk belemmerd worden in de aktivatie van die kennis. Experts, tenslotte, passen - naar wij aannemen - gecompileerde kennis toe. Als een deel van zo'n kennisbestand eenmaal geaktiveerd is, dan is er geen extra tijd nodig om de andere delen van die kennis te aktiveren. Experts zullen dus nauwelijks last hebben van beperking van de bestuderingstijd.

Deze verschillen in het gemak waarmee de kennis wordt geaktiveerd, zullen repercussies hebben voor de interne representatie van het probleem en daarmee voor de recall. Aangenomen wordt dat personen van een intermediair expertiseniveau bewust een redenering moeten opbouwen, waarbij ze gebruik maken van een geëlaboreerd kennisbestand. Bij hun zal de aktivatie van de kennis duidelijk belemmerd worden door beperking van de bestuderingstijd. Dientengevolge zal ook de probleemrepresentatie worden beinvloed door een dergelijke manipulatie. Voor beginnelingen zal het weinig uitmaken of ze veel of weinig tijd krijgen om een casus te bestuderen. Hun kennis zal hoe dan ook ontoereikend zijn om een samenhangende representatie van de casus op te bouwen. Daarvoor hebben ze gewoon nog te weinig kennis tot hun beschikking. Experts tenslotte, wier kennis ook onder beperkte bestuderingstijden volledig geaktiveerd zal worden door de casus, zullen ongeacht de tijd die ze ervoor krijgen een even uitgebreide probleemrepresentatie opbouwen. Deze theoretische overwegingen leiden tot de volgende voorspellingen: 
a) De proefpersonen van een intermediair niveau zullen bij een lange bestuderingstijd een uitgebreidere interne representatie van een casus opbouwen dan beginners en experts. Zij zullen zich dus ook meer van de casus herinneren. Naarmate de toegestane bestuderingstijd meer beperkt wordt, zal de omvang van de probleemrepresentatie van de intermediaire proefpersonen afnemen. Bij een extreem korte bestuderingstijd zal hun recall veel sterker terugvallen dan bij beginners het geval zal zijn. Experts tenslotte, zullen steeds even veel van de casus kunnen reproduceren, ongeacht de hoeveelheid tijd die ze daarvoor tot hun beschikking hebben.

b) Doordat de relevante kennisdelen bij proefpersonen met een hoger expertiseniveau sneller beschikbaar zijn dan bij proefpersonen met een minder hoge mate van expertise, verwachten we dat het probleemmodel met een toenemend expertiseniveau een steeds belangrijkere rol zal spelen in de interne representatie. Dit zal tot uitdrukking komen in een toenemend aantal inferenties in de recall met een toenemend expertiseniveau. Bij de proefpersonen met een hoge mate van expertise zal het probleemmodel onder alle omstandigheden, dus bij ruime en bij zeer korte bestuderingstijd, worden geaktiveerd. Bij experts zal het aantal inferenties dat geproduceerd wordt dus niet beïnvloed worden door verkorting van de bestuderingstijd. Doordat proefpersonen met een intermediair niveau van expertise hun probleemmodel moeizaam moeten construeren, zullen met name zij ernstig benadeeld worden bij een beperking van de bestuderingstijd. Bij een korte bestuderingstijd zullen vooral deze groepen minder inferenties produceren.

c) Ook de kwaliteit van de diagnose die gesteld wordt op grond van de opgebouwde interne representatie zal samenhangen met het expertiseniveau van de proefpersonen. Een toenemende mate van expertise zal leiden tot een een betere diagnose. Beperking van de bestuderingstijd zal van invloed zijn op de kwaliteit van de diagnose. Doordat het probleemmodel van de experts gemakkelijker beschikbaar is, verwachten we daarbij dat experts ook in hun diagnose minder beïnvloed zullen worden door beperking van de tijd.

d) Gevorderde studenten zullen een casus verwerken door geëlaboreerde kennis aktief toe te passen. Kenmerken van de geaktiveerde kennis kunnen onderzocht worden door middel van een post hoc methode waarbij de proefpersonen gevraagd wordt de pathofysiologische processen te beschrijven, die ten grondslag liggen aan de gevonden verschijnselen (Patel en Groen, 1986; zie Hoofdstuk 1). We verwachten daarom dat gevorderde studenten uitgebreidere pathofysiologische verklaringen zullen genereren dan de experts, die gecompileerde kennis gebruiken. Ook bij de pathofysiologische verklaringen zal deze voorspelling alleen opgaan bij een lange bestuderingstijd. Bij een verkorting van de bestuderingstijd immers is onvoldoende tijd beschikbaar om het hele netwerk te aktiveren en dus zal de omvang van de pathofysiologische protocollen van met name de intermediaire groepen afnemen. Als deze verschillen in toegepaste kennis inderdaad ten grondslag liggen aan 
de gevonden verschillen in recall, dan zal er een significante correlatie gevonden moeten worden tussen de hoeveelheid recall en de omvang van de pathofysiologische verklaringen.

De hypothese dat in de eerste stadia van de verwerving van expertise er vooral sprake is van kennisaccumulatie, die in de latere stadia gevolgd wordt door compilatie zal ook op een meer direkte wijze worden onderzocht. Daartoe zullen de pathofysiologische protocollen vergeleken worden met een modelverklaring (Patel en Groen, 1986), die geacht mag worden de kennis te beschrijven die de gemiddelde expert toepast wanneer hij of zij de voorgelegde casus juist diagnosticeert. Deze modelverklaring is dus een volledige en juiste beschrijving van het proces dat ten grondslag ligt aan de verschijnselen die in de casus worden beschreven. De pathofysiologische protocollen van de proefpersonen zullen worden vergeleken met dit model. Als de kennis van experts meer gecompileerd is dan de kennis van beginners en gevorderden en het model op adequate wijze de kennis van de doorsnee expert beschrijft, dan zullen de protocollen van de experts een gelijke mate van detaillering hebben als dit model, terwijl de protocollen van de anderen gedetailleerder zullen zijn. Dit leidt tot de volgende voorspelling:

e) Experts zullen evenveel tussenliggende concepten nodig hebben om twee concepten, die deel uitmaken van het model, met elkaar te verbinden als in het model worden gebruikt. Beginners en gevorderden daarentegen, zullen vergeleken met experts en vergeleken met de modelverklaring, meer concepten gebruiken in hun pathofysiologische protocollen. Ook verwachten we dat de redeneringen in de pathofysiologische protocollen met een toenemend expertiseniveau meer overeen zullen komen met de redeneerlijnen die in de modelverklaring zijn te herkennen.

\section{EXPERIMENT 2}

\section{Methode}

\section{Materiaal}

De casus die in dit experiment is gebruikt, is een vertaling van de Acute Bacteriêle Endocarditis casus, die ook in onderzoek van Patel en haar medewerkers gebruikt is (Patel en Groen, 1985, Coughlin en Patel, 1987). De tekst van deze casus, vertaald in het Nederlands, beslaat 252 woorden, die 23 zinnen vormen, verdeeld over 4 alinea's (zie kader 3.1). Het geheel bevat 79 proposities,

\section{Proefpersonen}

Aan dit experiment namen 120 proefpersonen deel. De eerste groep bestond uit 24 eerstejaars studenten gezondheidswetenschappen met 
Ben 27-jarige, werkeloze jonge man werd nax de Berste Hulp verwenen. Hij hiagde

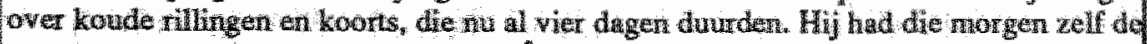
temperafur opgenomen en die bleek $40^{\circ} \mathrm{C}$ te ziju.

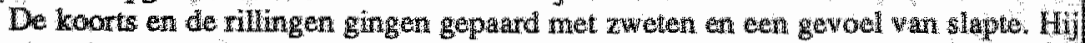

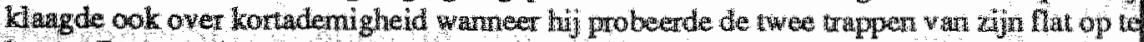
lopen. De pattent vertelde wil zichzed da hij een week vor zin verwijzing in het huis van een vilend door een kat gebeten was.

Verdere anaminese bracht een voorbijgaande visusdaing in her rechter oog aan het

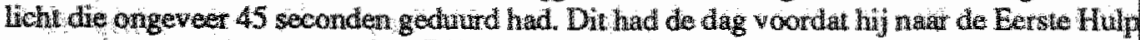
verwezen was, plaatsgevonden. Bul lichamelijk onderzok werd en toxische jongeman aargetroffen die net een koude rilHing had. Zijn temperatur was $41^{\circ} \mathrm{C}$. De pols was 124 per minut Bloeddruk 10/40. De sigmwiezen toonden geen afwiknger. Bij onderzodid van de ledernaten werden in de linke elleboogplooi restanten van verapunkties gezion. E werder geen andere hurdafwijkingen gevonden.

Verder onderzoek toonde geen gestawde halswener. De polsfrequentie is regulair equat, er isen polsdeficit. Verder werd geconstateerd dat de trequentie daalde. De apex wan het hart was niet yerplaatst. Auscul tate bracht cen $2 / 6$ vroeg diastolisch goruis ter hoogte van aortaklep an het bht. Fundusscopie toonde een vlam-vomige bloeding in het linker oog. De milt was niet vergroat. In de urine werden veel erythrocyted aangetroffen. Er waren geen erytrocyten-cylinders bil microscopiseh onderzoek.

Kader 3.1. Tekst van de Acute Bacteriele Endocarditis casus, gebruikt in Experiment 2

slechts VWO als vooropleiding. Deze studenten hadden net een onderwijsblok achter de rug, waarin de eerste elementaire begrippen van de ventilatie en de bloedsomloop aan de orde waren geweest. Voor het overige kunnen zij beschouwd worden als leken op het terrein van de aangeboden casus. De tweede groep bestond uit 24 tweedejaars studenten geneeskunde. Zij mogen geacht worden alle relevante basiskennis te beheersen, zowel waar het het normale funktioneren als waar het de basale pathofysiologische processen betreft. Kennis over ziektebeelden ontbreekt echter nog bij hen. De derde groep bestond wit vierdejaars studenten geneeskunde, die geacht mogen worden alle theoretische kennis te hebben die relevant is voor de voorgelegde casus. De vierde groep bestond uit zesdejaars studenten geneeskunde. Allen hadden het co-schap interne geneeskunde achter de rug, zodat zij ook in de praktijk hebben kunnen kennismaken met het type ziektebeelden waarvan de op te lossen casus een voorbeeld is. De laatste groep tenslotte bestond uit 24 internisten en assistenten interne geneeskunde met ten minste twee jaar klinische ervaring.

\section{Procedure}

Deze proefpersonen kregen een set formulieren uitgereikt, waarvan de voorste pagina blanco was. Op de volgende pagina stond de bacteriele endocarditis casus beschreven. De opdracht was daarbij deze gedurende een bepaalde tijd te lezen. Daarna volgden drie pagina's, waarop achtereenvolgens gevraagd werd op te schrijven wat ze zich van de casus konden herinneren, waarbij met klem werd gevraagd volledige zinnen te gebruiken en afkortingen te vermijden. Op de volgende pagina werd gevraagd hoe naar de mening van de proefpersoon de diagnose luidde. Tenslotte werd gevraagd het pathofysiologisch proces te beschrijven dat volgens de 
proefpersoon ten grondslag ligt aan de gevonden verschijnselen. Ook hier werd verzocht afkortingen te vermijden, hele zinnen te gebruiken en alleen dan gebruik te maken van schematische voorstellingen als het strikt noodzakelijk is.

Bij dit onderzoek werden drie verschillende bestuderingstijden gebruikt. De lange bestuderingstijd van 3 minuten en 30 seconden $\left(3^{\prime} 30^{\prime \prime}\right)$ komt overeen met de bestuderingstijd die in de oorspronkelijke experimenten van Patel et al. werd gebruikt. De kortere bestuderingstijd van 1 minuut en 15 seconden $\left(1^{\prime} 15^{\prime \prime}\right)$ was bepaald in een voorstudie met een aantal cardiologen. Hierin werd de tijd gemeten die verstreek tussen het ogenblik waarop zij begonnen met lezen en het moment waarop zij hun eerste diagnostische hypothese uitten. De kortste bestuderingstijd van 30 seconden ( $\left.30^{\prime \prime}\right)$ komt overeen met de tijd die iemand ongeveer nodig heeft om een tekst van vergelijkbare lengte over een bekend onderwerp te scannen. In alle gevallen werd de proefpersonen vooraf meegedeeld hoe lang zij de tijd hadden om de casus te bestuderen. De proefpersonen die slechts 30 seconden bestuderingstijd tot hun beschikking hadden, kregen voorafgaand aan de casus gedurende eveneens 30 seconden een tekst van gelijke lengte voorgelegd, die ontleend was aan een sportbericht. Op deze wijze konden zij zelf vaststellen of zij hun leessnelheid moesten aanpassen om daarna de casus in zijn geheel te kunnen doornemen.

\section{Analyse}

Free recall-De recallprotocollen werden opgedeeld in proposities. Deze proposities werden vergeleken met de geanalyseerde casus en beoordeeld op aanwezigheid en juistheid. Dit gebeurde op dezelfde wijze als gedaan is in Experiment 1. Op basis van deze analyse werd bepaald hoeveel juiste proposities in de recall aanwezig waren. Ook werd het aantal inferenties vastgesteld. Deze werden weer gedefinieerd als het aantal conclusies dat gebaseerd is op twee of meer proposities uit de casus. De maat die gebruikt werd om de omvang van de interne representatie te berekenen was weer dezelfde als de recallmaat in Experiment 1, namelijk de som van het aantal juiste proposities plus het aantal inferenties.

Diagnose- De volledige diagnose voor deze casus luidt: acute bacteriele endocarditis met embolieèn vermoedelijk op basis van gebruik van vulle injectienaalden. De diagnose van de proefpersonen werd gescoord met behulp van de componenten, die aan deze diagnose te onderscheiden zijn. Stelde iemand de diagnose 'endocarditis', dan werd daarvoor twee punten gegeven terwijl voor iedere andere component, acuut, bacterieel, embolieẻn en vuile naalden, én punt werd gegeven. De maximale score die op deze wijze bereikt kan worden, bedraagt zes punten.

Pathofysiologie-De pathofysiologische protocollen werden ten slotte opgedeeld in proposities. Om de omvang van het pathofysiologieprotocol vast te stellen werd het aantal proposities geteld. Tevens werd het aantal concepten in deze proposities vastgesteld. Kennisaccumulatie zal tot uitdrukking komen in een toename van het aantal proposities. 
Om de compilatie van kennis te kunnen onderzoeken werden de pathofysiologische protocollen van de proefpersonen vergeleken met een ideaal pathofysiologisch model (Patel en Groen, 1985). Dit ideaaltypisch pathofysiologisch model is gerepresenteerd als een propositioneel netwerk (zie Figuur 3.2).

Als uitgangspunt voor de constructie van dat model werden de verschillende componenten van de diagnose gebruikt. Dit zijn dus a) het gebruik van vervuilde naalden, b) de sepsis, c) de endocarditis, d) de embolieën en e) het acute aspekt. Deze vijf componenten werden in een causaal model geplaatst. Waar nodig, werden daarbij pathofysiologische concepten toegevoegd (klepvegetaties of abces op aortaklep). Vervolgens werden de casusgegevens aan het model gekoppeld en weer werden, als deze gegevens niet rechtstreeks met de reeds aanwezige concepten in het netwerk samenhingen, de relevante tussenliggende concepten toegevoegd: druggebruik, verminderde weerstand, ontkennend gedrag, pre-existent kleplijden en aorta-insufficièntie. Het model dat op deze wijze werd ontworpen, werd getoetst aan de relevante cardiologische literatuur (Braunwald, 1988; Braunwald, Isselbacher, Peterdorf, Wilson, Martin en Fanci, 1987; Danner, Wieling, Roos en Dunning, 1981; Epen, 1983), waarna het werd voorgelegd aan een internist en een cardioloog. Deze procedure resulteerde via een reeks van bijstellingen in het model dat weergegeven is in Figuur 3.2. Dit model weerspiegelt als het ware de kennis die de artsen gebruiken bij het oplossen van deze casus. Het representeert de geaktiveerde en geïnstantieerde kennis van de artsen met betrekking tot het onderwerp endocarditis bij drugsgebruikers.

Dit model werd vergeleken met de pathofysiologische verklaringen die de proefpersonen van de casus gaven. Daartoe werden de pathofysiologische protocollen ook omgezet in propositionele netwerken (Figuur 3.1 is een voorbeeld van zo'n propositioneel netwerk). Deze propositionele netwerken werden gematched met het model.

Om de kennisaccumulatie te onderzoeken werd het aantal overeenkomstige concepten geteld. Deze concepten noemen we modelconcepten. Vervolgens werden de overeenkomstige redeneerstappen onderzocht. Hiertoe werden ten eerste het aantal identieke redeneringen geteld. Hiervan was sprake wanneer de redeneringen van het ene concept naar een ander concept in het netwerk via dezelfde tussenliggende concepten verliep. Daar waar afwijkingen werden gevonden, werd vervolgens bepaald of er sprake was van een verkorting van een pad in het modelnetwerk of dat er sprake was van een alternatief pad.

Van een verkorting is sprake wanneer het aantal redeneerstappen dat gebruikt wordt orn van het ene concept naar een ander concept in het netwerk te komen, in het propositionele netwerk van de proefpersoon kleiner is dan in het modelnetwerk. Van een alternatief pad is sprake wanneer de verbinding tussen twee concepten in het netwerk van de proefpersoon via andere concepten verloopt dan in het modelnetwerk het geval is. 


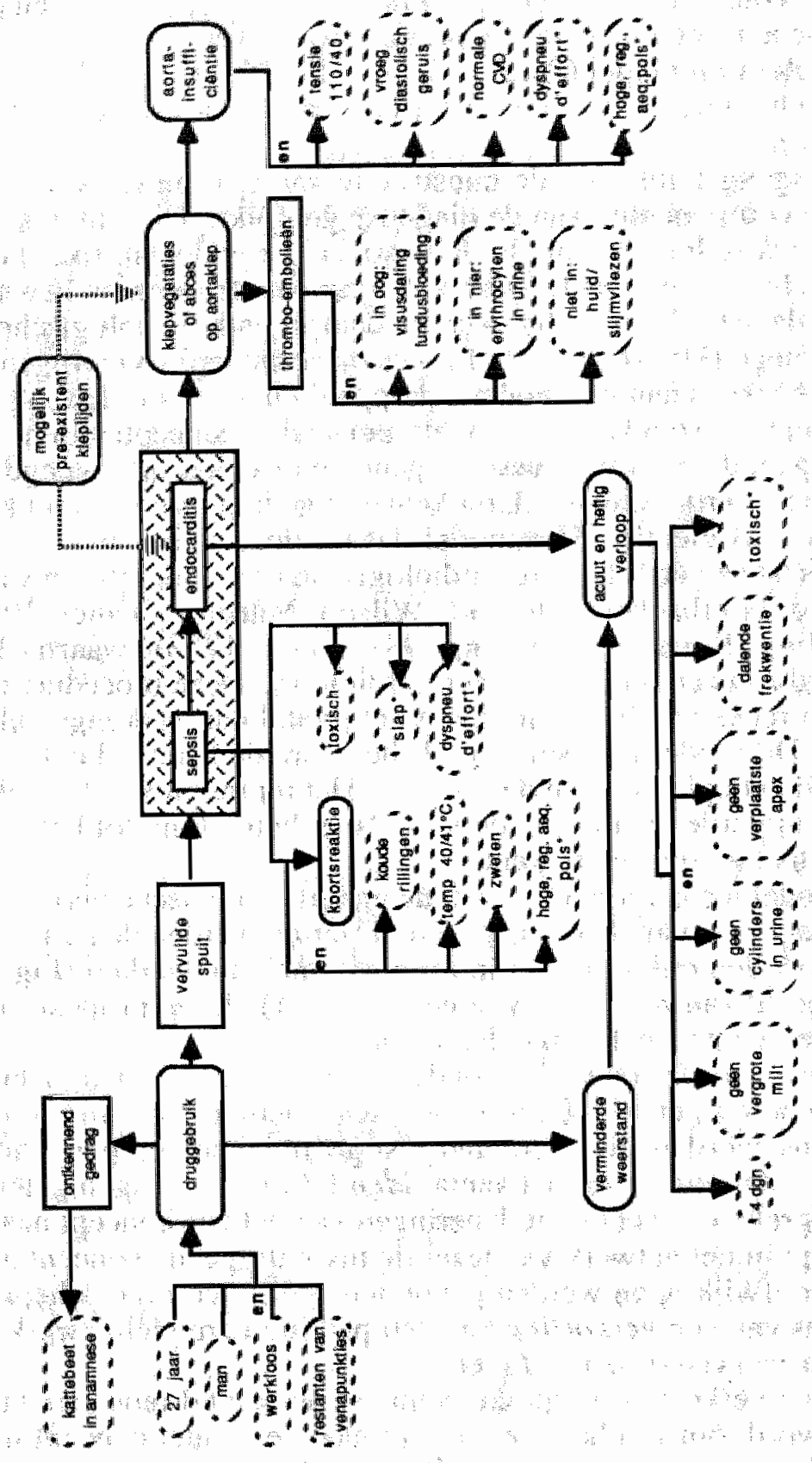

Figuur 3.2. Modelverklaring van de Acute Bacteriële Endocarditis casus 
Van compilatie van de kennis kan slechts sprake zijn wanneer er identieke redeneringen en verkortingen worden gevonden. Het aantal alternatieve paden moet daarbij laag zijn.

\section{Resultaten en Discussie}

Hoeveelheid recall-De hoeveelheid proposities die men zich van een casus kan herinneren, blijkt samen te hangen met het expertiseniveau $(F(4,105)=5.251, p=.0007)$. Ook in Experiment 2 vinden we weer geen rechtlijnig verband tussen deze variabelen. In tegendeel, de lineaire component draagt niet significant bij aan deze relatie in tegenstelling tot de kwadratische component $(\mathrm{F}(1,115)=7.0181, \mathrm{p}=.0092$, waarbij geen sprake is van significante afwijkingen). Aangezien ook de derde en vierde machtscomponenten geen significante bijdrage hebben, kunnen we met groepsgemiddelden van $20.5,27.7,26.9,29.3$ en 21.5 wel zeggen dat er in dit experiment sprake is van een omgekeerd U-vormig verband tussen mate van expertise en hoeveelheid recall.

Voorspeld werd dat de hoeveelheid recall van de groepen met een intermediair expertiseniveau groter zou zijn dan van beginners en experts wanneer ze een ruime bestuderingstijd tot hun beschikking zouden hebben. Dit effekt zou echter verdwijnen wanneer de hoeveelheid beschikbare tijd beperkt zou worden. De resultaten die op deze voorspelling betrekking hebben, zijn als volgt (zie ook Figuur 3.3). Bij een lange bestuderingstijd $\left(3^{\prime} 30^{\prime \prime}\right)$ is er sprake van een significant effekt van expertise op recall van de casus $(F(4,35)=5.642, p=.0013)$. De lineaire component in deze relatie is significant $(F(1,35)=6.1391, p=.0182$, echter met significante afwijkingen van lineariteit: $\mathrm{p}=.0034)$. De kwadratische component overheerst $(\mathrm{F}(1,35)=12.4692, \mathrm{p}=.0012$, zonder significante afwijkingen $)$. Dit betekent dus dat het eerder gevonden omgekeerd U-vormig verband optreedt bij een lange bestuderingstijd. Verkorten we die tijd tot 1 minuut en 15 seconden, dan verdwijnt de relatie tussen expertiseniveau en recall $(\mathrm{F}(4,35)=2.1787, \mathrm{p}=.0917)$. Geven we de proefpersonen nog minder tijd om de casus te bestuderen, dan vinden we wel weer een relatie tussen expertiseniveau en recall van de casus $(F(4,35)=4.8126, p=.0034)$. $\mathrm{Nu}$ echter vertoont de gevonden curve geen top bij de intermediaire groepen, Er is sprake van een significante lineaire component $(F(1,35)=8.776$, $p=$ $.0055)$, maar met significante afwijkingen $(\mathrm{p}=.0257)$ die het gevolg zijn van een significante derde machtscomponent $(F(1,35)=7.881, p=.0081)$. Dit betekent dus dat met een verkorting van de toegestane bestuderingstijd de vorm van de curve en dus van de relatie tussen expertiseniveau en hoeveelheid recall van de casus verandert; deze verandert van een omgekeerd U-vormig in een vrijwel lineair verband (zie Figuur 3.3). Het interaktie-effekt tussen bestuderingstijd en expertiseniveau dat met dit verschijnsel is geassocieerd, is duidelijk significant $(F(8,105)=4.011, p=$ .0003 ).

Er is niet alleen sprake van een verandering van de vorm van de curves. Ook de gemiddelde hoeveelheid recall wordt duidelijk beïnvloed door 
een verkorting van de leestijd. Bij de lange bestuderingstijd bedroeg deze gemiddeld 36.525 proposities. Proefpersonen die 1' $15^{\prime \prime}$ de tijd hadden gekregen, scoorden gemiddeld 24.35. De ultra korte bestuderingstijd leidde tot een recall van 14.65 proposities $(F(2,105)=68.26, p=.0001)$.

Wanneer we het effekt van een beperking van de bestuderingstijd bij de verschillende expertisegroepen afzonderlijk beschouwen, dan valt een aantal verschijnselen op. Bij de langste bestuderingstijd is de omvang van de interne representatie van de internisten en de studenten gezondheidswetenschappen het minst omvangrijk. $\mathrm{Zij}$ reproduceren significant minder proposities dan de studenten geneeskunde ( $\leq .001$ ). Bij de groepen die $11^{\prime \prime}$ bestuderingstijd werd gegeven, reproduceren alleen de vierdejaars en zesdejaars studenten geneeskunde meer proposities dan de anderen. Bij de kortste bestuderingstijd tenslotte is de interne representatie van de internisten en de zesdejaars studenten uitgebreider dan van de andere groepen. Beperking van de bestuderingstijd leidt bij alle groepen tot significante vermindering van de recall $(\mathrm{p}<.001)$, behalve bij de internisten $(F(2,21)=$ $1.349, p=.2811$ ).

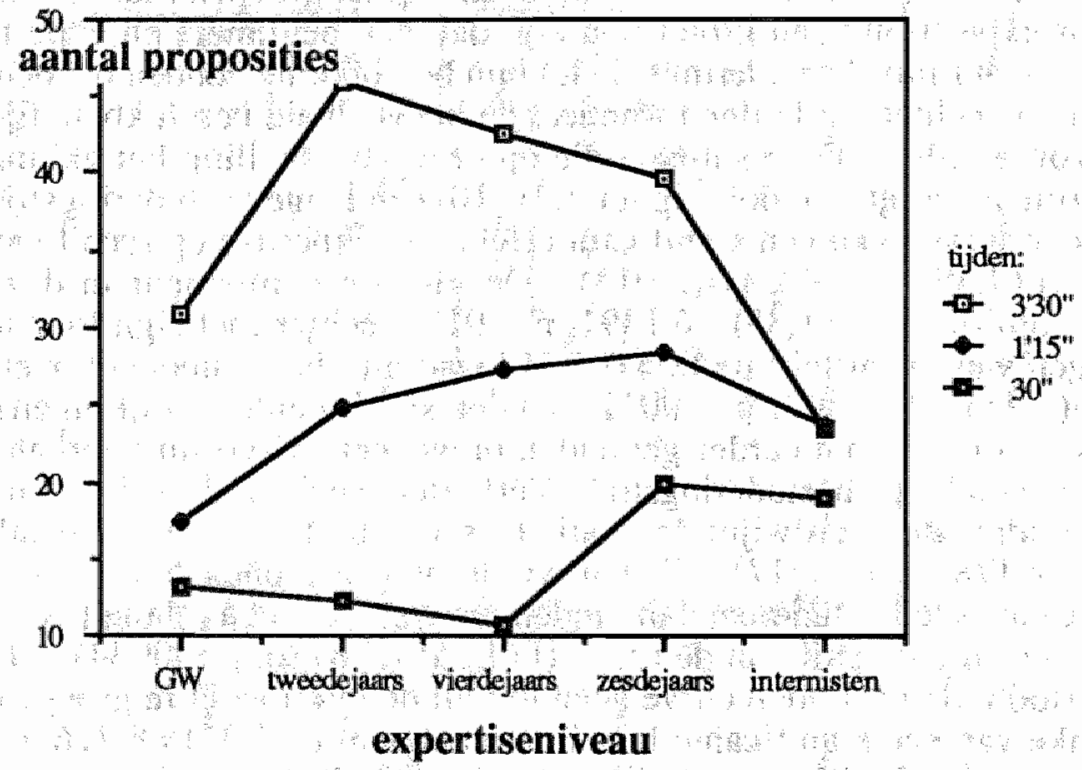

Figuur 3.3 De hoeveelheid recall van de casus (uitgedrukt in het aantal juiste proposities plus de inferenties) van de verschillende expertisegroepen onder drie verschillende bestuderingstijden.

Deze resultaten bevestigen twee hypothesen, namelijk dat de recall van proefpersonen van een intermediair expertiseniveau uitgebreider is dan van beginners en van experts indien hen daarvoor voldoende bestuderingstijd wordt gelaten. Indien de bestuderingstijd beperkt wordt, heeft dit een differentieel effekt op proefpersonen van verschillend expertiseniveau. Beperking van de bestuderingstijd had effekt op alle studentproefpersonen, maar niet op de internisten. Dit ondersteunt de theorie dat proefpersonen 
van een intermediair expertiseniveau bij de representatie van een probleem een kennisbestand gebruiken dat niet in én keer geaktiveerd wordt. In tegenstelling tot de experts moeten zij dus bewust redeneren.

Inferenties- Doordat de kennis van meer ervaren personen sneller beschikbaar is, verwachtten we dat het probleemmodel bij een toenemend expertiseniveau ook sneller volledig beschikbaar zou zijn. Dit zou tot uitdrukking komen in een toenemend aantal inferenties dat in de interne representatie is opgenomen. Figuur 3.41aat duidelijk zien dat deze relatie in de data aanwezig is.

Er is sprake van een significant effekt van expertiseniveau op het aantal inferenties in de recall $(\mathrm{F}(4,105)=25.658, \mathrm{p}=.0001)$. De lineaire component in deze relatie is zeer sterk $(F(1,115)=88.1589, p=.0000$, met significante afwijkingen van lineariteit, $\mathrm{p}=.0002$ ). Ook de kwadratische component is significant $(F(1,115)=20.998, p=.0000)$.

We namen echter ook aan dat beperking van de bestuderingstijd vooral het beschikbaar komen van het probleemmodel van de intermediaire proefpersonen zou beïnvloeden. Hierdoor zou beperking van de bestuderingstijd met name het aantal inferenties van de intermediaire expertiseniveaus beïnvloeden, terwijl de experts er niet door zouden worden beïnvloed. Deze laatste voorspelling werd niet bevestigd. Experts blijken weliswaar onder alle bestuderingstijden evenveel inferenties te produceren, maar dat is ook het geval bij de minder ervaren groepen. Het interaktieeffekt dat we bij deze hypothese hadden moeten vinden, was geheel afwezig $(F(8,105)=.177, p=9936)$.

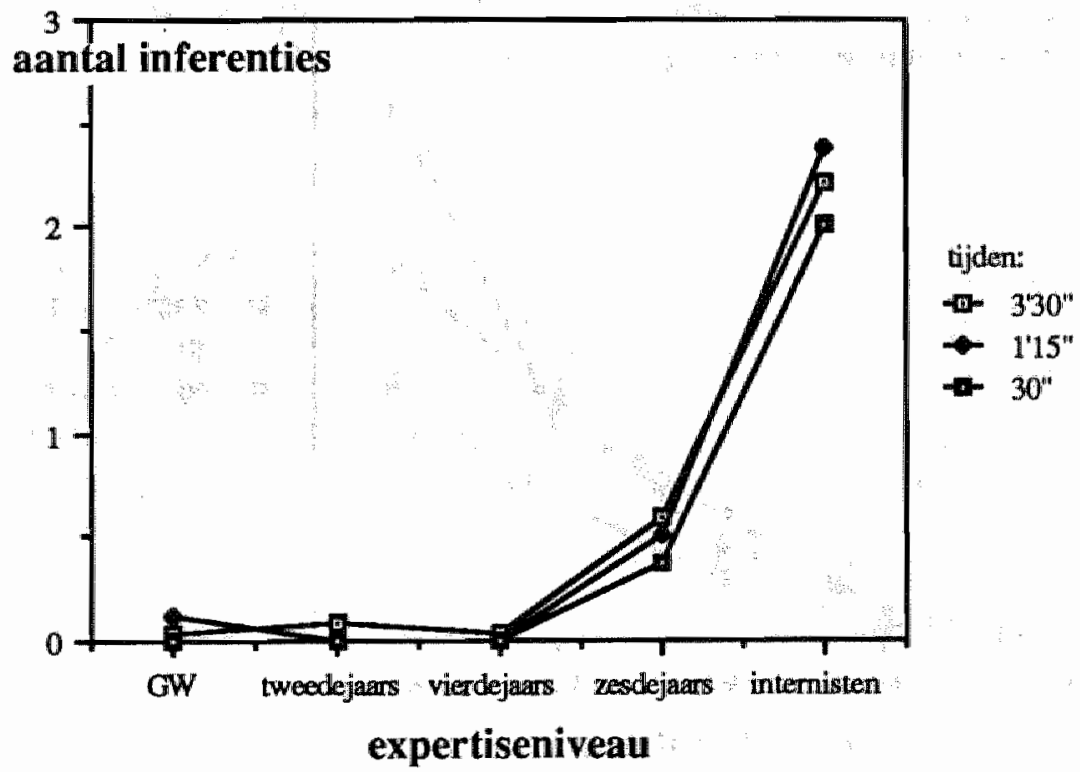

Figuur 3:4 Aantal inferenties in de recallprotocollen. 
Ook een algemene invloed van de gebruikte bestuderingstijd bleek niet aanwezig $(\mathrm{F}(2,105)=.625, \mathrm{p}=.5371)$. Een verklaring hiervoor zou kunnen zijn dat de tweedejaars en vierdejaars studenten hoegenaamd geen inferenties produceren (zie Figuur 3.4). Vermindering van dit aantal ten gevolge van een korte bestuderingstijd, zoals we voorspelden, was dus onmogelijk. De zesdejaars studenten produceren ook nauwelijks inferenties: gemiddeld een halve per persoon. Alleen de interne representatie van de internisten bevat een substantieel aantal inferenties (gemiddeld 2.2 inferenties). De hoeveelheid daarvan wordt, zoals was voorspeld, niet beinvloed door verkorting van de bestuderingstijd $(\mathrm{F}(2,21)=.107, \mathrm{p}=$ .8992).

Deze resultaten laten dus zien dat met een toenemend expertiseniveau de rol van het probleemmodel in de interne representatie steeds belangrijker wordt. We hoopten op deze wijze een nadere bevestiging te vinden van de stelling dat de kennis van intermediairen geellaboreerd is waardoor het probleemmodel via redeneringen geconstrueerd moet worden. Er trad echter bij de betrokken expertisegroepen een bodemeffekt op, waardoor de hypothese bevestigd noch verworpen kan worden.

Diagnostische accuratesse-In Figuur 3.5 is de gemiddelde accuraatheid weergegeven van de diagnosen die door de proefpersonen werden genoemd. Deze diagnostische accuratesse bleek, zoals verwacht, een duidelijke samenhang te vertonen met het expertiseniveau van de proefpersonen $(\mathrm{F}(4,105)=25.527, \mathrm{p}=.0001)$. Ook de leestijd had, conform de voorspelling, een duidelijke invloed op de kwaliteit van de diagnose $(\mathrm{F}(2,105)=3.163, \mathrm{p}=.0464)$.

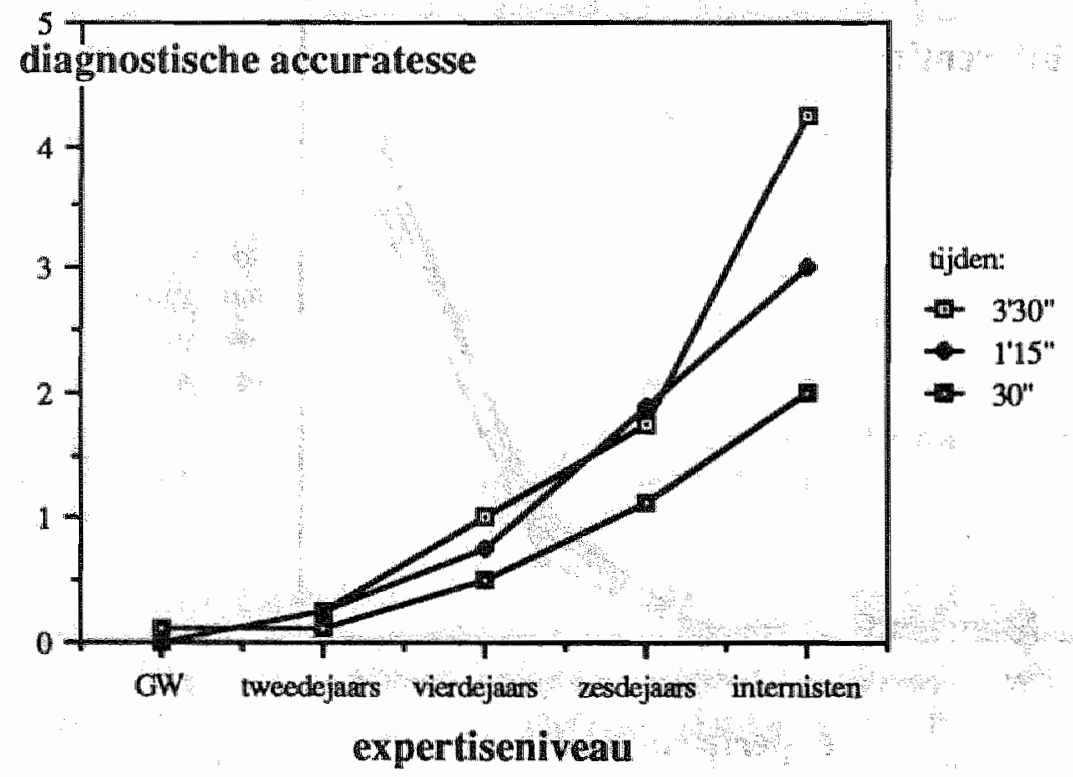

Figuur $3.5 \mathrm{~K}$ waliteit van de diagnose van proefpersonen van verschillend niveau van expertise, bij variatrende leestijden. 
Per expertiseniveau afzonderlijk zijn deze verschillen echter niet significant. Dit geldt ook voor de expertgroep $(F(2,21)=2.62, \mathrm{p}=.0965)$. De voorspelling dat experts minder te lijden zullen hebben onder een beperking van de bestuderingstijd werd niet bevestigd. Ook bij deze voorspelling voorkomt een bodemeffekt in de scores van de intermediaire groepen, dat een verkorting van de bestuderingstijd tot uitdrukking kan komen in een vermindering van de diagnostische accuratesse van de betreffende groepen.

Deze resultaten laten zien dat het gebruikte probleemmodel met een toenemend expertiseniveau steeds beter aansluit bij de aandoening, waarvan in de casus feitelijk sprake was.

Omvang pathofysiologische verklaringen- De belangrijkste hypothese bij Experiment 2 gaat uit van de veronderstelling dat het eerder gevonden verband tussen expertiseniveau en hoeveelheid recall veroorzaakt wordt door het gebruik van kwalitatief verschillende kennis. De kennis van de intermediaire proefpersonen zou nog niet gecompileerd zijn, waardoor deze aktief redenerend en elaborerend moet worden toegepast. Experts daarentegen passen kennis toe waarin de zoekpaden sterk verkort zijn en die gekleurd is door de ervaring die men heeft. Dit verschil in aard van de kennis zal tot uitdrukking moeten komen in de omvang van de pathofysiologische protocollen. Voorspeld werd dat gevorderden uitgebreidere pathofysiologische verklaringen zullen genereren dan experts. Doordat beginners nog zeer onvolledige kennis toepassen, zullen hun pathofysiologische verklaringen ook minder uitgebreid zijn.

De analyses laten zien dat de omvang van de pathofysiologische protocollen een duidelijk effekt van het expertiseniveau vertoont $(F(4,105)=$ $6.488, \mathrm{p}=.0001)$. Het voorspelde omgekeerd $\mathrm{U}$-vormig verband tussen expertiseniveau en de omvang van de pathofysiologische protocollen wordt bevestigd door de polynoomanalyses. Er is geen sprake van een significante lineaire component, terwijl een kwadratische component wel wordt gevonden $(F(1,115)=19.0265, p=0000$, zonder significante afwijkingen: $p=.2930$ ). De top van deze curve ligt bij de zesdejaars studenten. De gemiddelde omvang van de pathofysiologische protocollen bedraagt 15.2 proposities bij de studenten gezondheidswetenschappen. De studenten geneeskunde aktiveren duidelijk meer kennis: gemiddeld produceren de tweedejaars studenten 16.6 proposities, de vierdejaars produceren gemiddeld 20.7 proposities, terwijl de omvang van de protocollen van de zesdejaars studenten gemiddeld 23.8 proposities bedraagt. De protocollen van de internisten zijn weer minder omvangrijk: gemiddeld 12.6 proposities. 


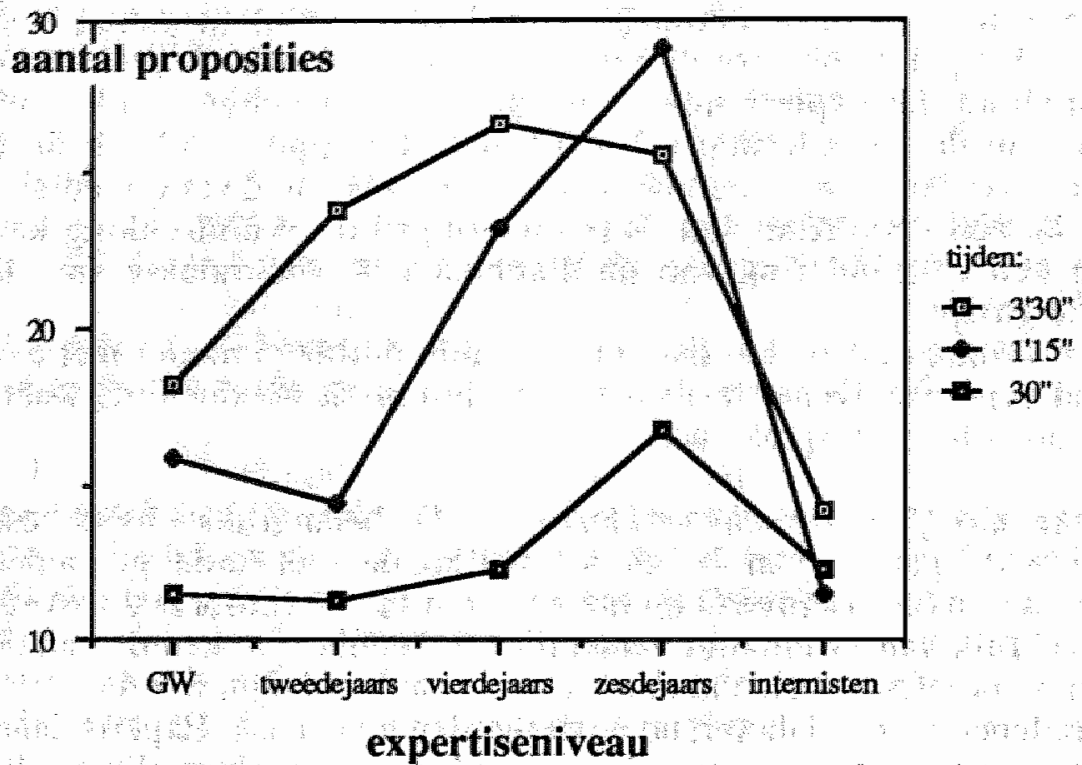

Figuur 3.6 Uitgebreidheid van de pathofysiologische verklaringen, uitgedrukt in het aantal proposities.

Verder is er sprake van een significant effekt van de genoten bestuderingstijd $(F(2,105)=11.148, p=.0001)$. Proefpersonen die de langste bestuderingstijd kregen, produceerden ook uitgebreidere pathofysiologische protocollen dan proefpersonen die minder tijd te besteden hadden, terwijl degenen die slechts een halve minuut tot hun beschikking hadden de minst omvangrijke protocollen produceerden. Voorspeld werd dat beperking van de bestuderingstijd vooral van invloed zou zijn op de omvang van de pathofysiologische verklaringen van de intermediaire groepen, omdat zij hun kennis aktief redenerend en elaborerend moeten toepassen. Verwacht wordt dus dat het omgekeerd U-vormig verband tussen expertiseniveau en omvang van de pathofysiologische protocollen zal verdwijnen met een afnemende bestuderingstijd. Polynoomanalyse laat zien dat zowel bij een ruime bestuderingstijd ( $3^{\prime} 30^{\prime \prime}$ ) als bij een bestuderingstijd van 1 minuut en 15 seconden significante kwadratische componenten worden gevonden. Deze is in het geval van de lange bestuderingstijd $(F(1,35)=8.3320, p=$ .0066 , zonder significante afwijkingen: $p=9386$ ) wat minder sterk dan bij de kortere bestuderingstijd $(F(1,35)=12.9109, \mathrm{p}=.0010$, ook zonder significante afwijkingen: $p=1591$ ), Bij de extreem korte bestuderingstijd vinden we geen relatie met expertiseniveau. Analyse van de afzonderlijke expertisegroepen laat zien dat de tweedejaars en vierdejaars studenten geneeskunde duidelijk beïnvloed worden door beperking van de bestuderingstijd ( $\mathrm{p} \leq .01$ ). De omvang van de pathofysiologische protocollen van de internisten wordt daarentegen in het geheel niet beïnvloed door beperking van de bestuderingstijd $(F(2,21)=.402, p=.6742)$. Bij de studenten gezondheidswetenschappen en bij de zesdejaars studenten is geen duidelij- 
ke uitspraak mogelijk over een effekt van verkorting van de bestuderingstijd ( $>>$.10).

De product-moment correlatie tussen recall en de omvang van de pathofysiologische protocollen bedraagt .508. Dit resultaat ondersteunt de veronderstelling dat gevonden verschillen in de aard en omvang van de kennis, die gebruikt wordt bij het representeren van de casus ten grondslag liggen aan de gevonden recallverschijnselen.

De uitkomsten van de analyses van de hoeveelheid kennis, die toegepast wordt bij het diagnosticeren van een casus door proefpersonen van verschillende expertiseniveaus zijn conform de voorspellingen, die gedaan werden op grond van de theorie over de ontwikkelingsstadia, die de kennis doormaakt. Het zou echter wat voorbarig zijn om op grond van deze resultaten te concluderen dat er dus in de eerste stadia van het ontwikkelingsproces sprake is van kennisaccumulatie die in de latere stadia gevolgd wordt door compilatie van de kennis. De volgende analyses zijn gedaan om deze conclusie nader te onderbouwen.

Kennisaccumulatie- Het model van leren, waarvan in dit proefschrift wordt uitgegaan, voorspelt dat in de eerste stadia van expertiseverwerving de hoeveelheid gebruikte kennis zal toenemen. Het aantal proposities in de pathofysiologische protocollen van de studenten zou dus moeten toenemen. Dit bleek ook het geval te zijn. Ook wanneer we alleen dit trajekt van de kennisverwerving beschouwen is er een significante samenhang tussen expertiseniveau en de omvang van de pathofysiologische verklaringen $(F(3,92)=3.655, p=.0154)$. Alleen de lineaire component in deze relatie is significant $(F(1,92)=10.9069, p=.0014$, zonder dat er sprake is van significante afwijkingen van lineariteit). Dit bevestigt dus de hypothese.

Compilatie van de kennis- Toetsing van de hypothese dat er in de latere stadia van de expertiseverwerving sprake is van compilatie van kennis verliep in twee stappen. Eerste werd de inhoudelijke gelijkenis tussen de pathofysiologische protocollen en de modelverklaring onderzocht. Om dit te onderzoeken, werd gekeken of de concepten die deel uitmaken van de pathofysiologische verklaringen van de proefpersonen overeenstemden met de concepten in het opgestelde model: de modelconcepten in de protocollen werden daartoe geteld. Vervolgens werd de redeneerlijn, waarvan deze concepten deel uitmaken (bestaande uit cén of meer proposities), vergeleken met de redeneerlijn in de modelverklaring.

Teneinde de mate van inhoudelijke gelijkenis vast te stellen tussen een pathofysiologisch protocol van een proefpersoon en de modelverklaring, werd het aantal modelconcepten in de protocollen bepaald en werd de verhouding tussen het aantal model- en niet-modelconcepten berekend. Het aantal modelconcepten blijkt dan significant samen te hangen met het expertiseniveau $(F(4,105)=5.438, p=.0005)$. Het verband wordt echter gedomineerd door de kwadratische component $(\mathrm{F}(1,115)=11.7369$, 


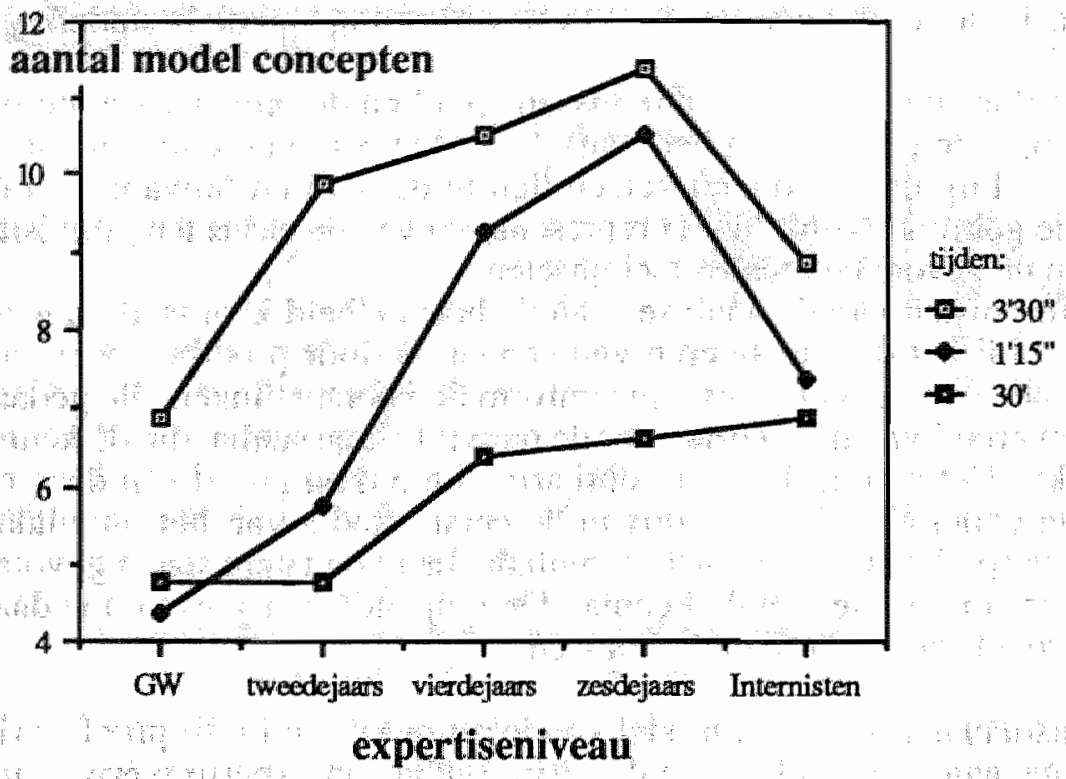

Figuur 3.7 Aantal modelconcepten in de pathofysiologische proposities die ontleend zijn aan de pathofysiologische protocollen.

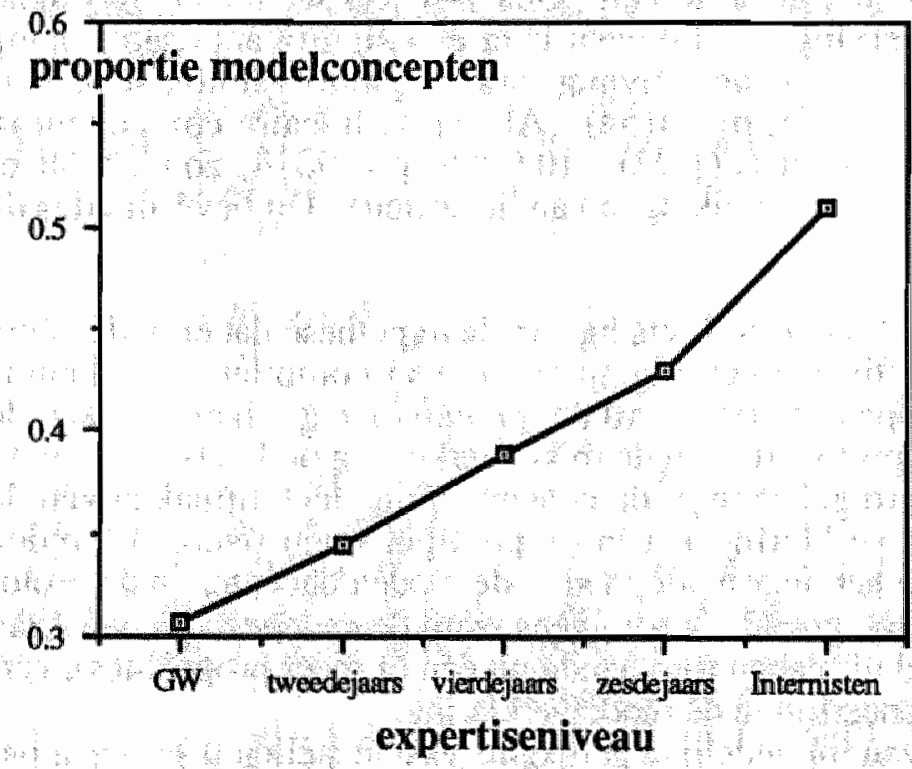

Figuur 3.8 Proportie modelconcepten in het totale pathofysiologische protocol ${ }^{3}$.

${ }^{3}$ Omdat er steeds geen sprake was van effekten van de bestuderingstijd, zijn in deze en de volgende figuren de resultaten niet voor de drie verschillende bestuderingstijden apart weergegeven. 
$\mathrm{p}=.0009)$ die groter is dan de lineaire component $(\mathrm{F}(1,115)=6.9220, \mathrm{p}=$ .0097 , waarop ook significante afwijkingen worden gevonden: $p=.0104$ ). Er is dus geen sprake van een lineair verband (zie Figuur 3.7). Het aantal modelconcepten in de pathofysiologische protocollen stijgt eerst met een toenemend expertiseniveau, maar na het zesde jaar daalt dit aantal weer. Dit verschijnsel komt echter voort uit het verschil in omvang van de pathofysiologische protocollen.

Wanneer we hiermee rekening houden, dan blijkt de proportie modelconcepten in de protocollen te stijgen met een toenemend expertiseniveau $(\mathrm{F}(4,105=5.77, \mathrm{p}=.0003$, met alleen een significante lineaire component: $F(1,115)=23.8561, p=.0000$, zonder significante afwijkingen: $p=$ $.9891)$.

Bij het absolute aantal modelconcepten in de pathofysiologische protocollen wordt ook weer een effekt van de bestuderingstijd gevonden $(F(2,105)=11.256, p=.0001)$. Na correctie voor de omvang van het protocol verdwijnt dit verschil echter $(\mathrm{F}(2,105)=.815, \mathrm{p}=.445)$ (zie Figuur 3.8).

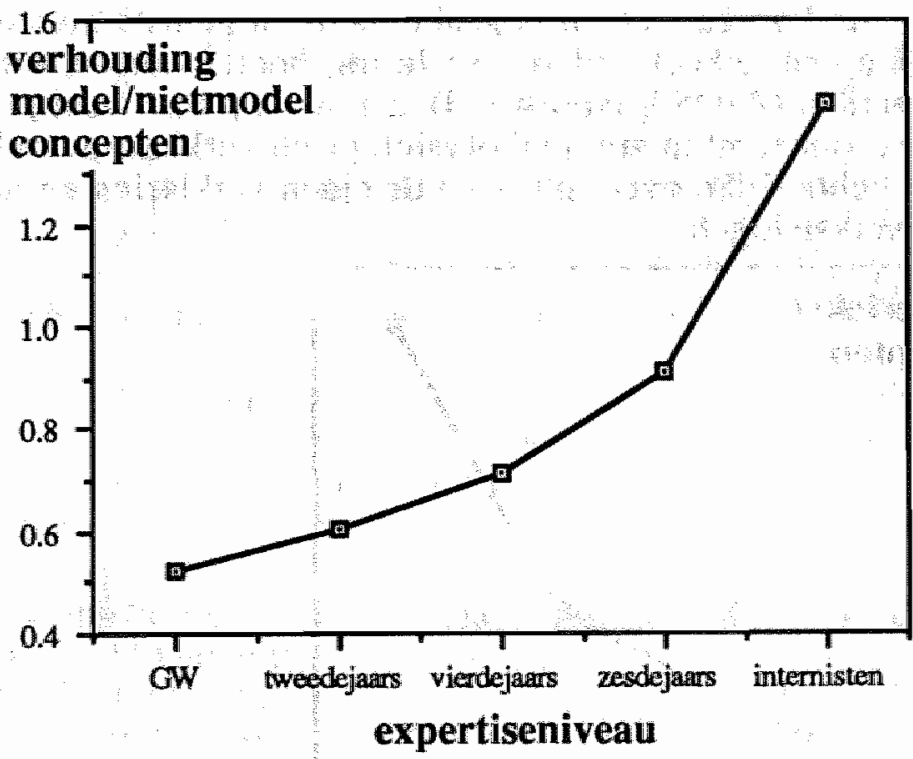

Figuur 3.9 De verhouding tussen het aantal modelconcepten en niet-modelconcepten in de pathofysiologische protocollen van proefpersonen van verschillend expertiseniveau.

De beste indicatie voor de inhoudelijke gelijkenis tussen het pathofysiologische protocol van de proefpersonen en de modelverklaring wordt echter gevormd door de verhouding tussen het aantal modelconcepten en het aantal niet-modelconcepten. Deze verhouding is weergegeven in $\mathrm{Fi}$ guur 3.9. Ook deze variabele blijkt significant samen te hangen met het expertiseniveau van de proefpersonen $(F(4,105)=6.614, p=.0001)$. De lineaire component in dit effekt is significant $(F(1,115)=26.3975, p=$ 
.0000 , zonder dat er sprake is van significante deviaties: $p=.6658$ ). Een toenemend expertiseniveau gaat dus gepaard met een toenemende mate van overeenstemming tussen pathofysiologische verklaringen van de proefpersonen en de modelverklaring.

Tenslotte is nagegaan welke concepten wit het model de proefpersonen in hun eigen verklaringen gebruikten. Deze laatste analyse is noodzakelijk omdat de modelverklaring de idealiter geaktiveerde en geïnstantieerde kennis weerspiegelt. Indien de proefpersoon deze kennis gebruikt bij het oplossen van het probleem komt hij of zij tot de juiste diagnose. Vanwege het "geînstantieerde karakter bevat het model twee typen concepten: generieke concepten, die de kennis zelf vertegenwoordigen (voorbeelden zijn 'klepvegetaties' en 'gebruik van vuile naalden') en specifieke concepten, waarmee het generieke kennisschema is geïnstantieerd. Voorbeelden van specifieke concepten zijn "man', 'werkloos' en 'koude rillingen'. Het zijn de concepten die aan de casusbeschrijving zelf zijn ontleend. In Figuur 3.2 zijn de specifieke concepten geplaatst in een gearceerd kader. Het gebruik van deze specifieke concepten zegt echter op zich niets over de kennis die met behulp van deze concepten is geaktiveerd en geïnstantieerd. Een proefpersoon die een geheel andere verklaring heeft voor de verschijnselen van de patiënt (AIDS bijvoorbeeld) kan, als hij maar veel gegevens van de patiënt opneemt in zijn pathofysiologisch verklaring, toch op deze manier een behoorlijke overlap tussen de eigen verklaring en de modelverklaring bewerkstelligen.

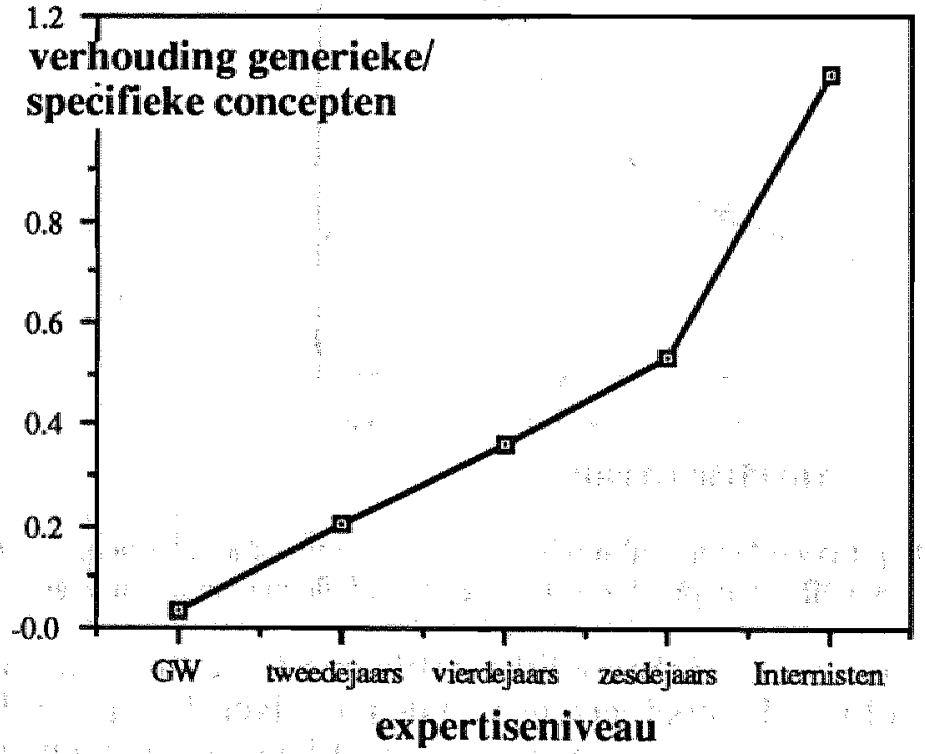

Figuur 3.10 Verhouding tussen het aantal generieke concepten en het aantal specifieke concepten in de pathofysiologische verklaringen bij de verschillende expertiseniveaus. 
Om dit effekt uit te zuiveren, werden in de pathofysiologische verklaringen van de proefpersonen beide typen concepten geteld. De verhouding tussen deze wee typen concepten is gebruikt om te bepalen in welke mate een proefpersoon dezelfde kennis toepast als waarmee in het model de verschijnselen van de patiënt worden verklaard. Hoe hoger dit getal, hoe groter het aandeel van de generieke concepten in de pathofysiologische protocollen.

In Figuur 3.10 zijn de resultaten van deze analyse weergegeven. Hieruit blijkt dat de verhouding tussen het aantal generieke concepten en het aantal specifieke concepten toeneemt met een toenemend expertiseniveau $(\mathrm{F}(4,105)=13.331, \mathrm{p}=.0001$; de lineaire component in deze relatie is significant: $F(1,115)=47.4358, p=.0000$, zonder significante deviaties van lineariteit: $p=.6461)$. Dit betekent dus dat de kennis, die toegepast wordt door personen van verschillend expertiseniveau in toenemende mate gelijkenis gaat vertonen met de kennis, die gerepresenteerd is in thet gebruikte model.

Deze vier analyses tezamen laten zien dat de pathofysiologische protocollen van de proefpersonen met een toenemend expertiseniveau meer en meer gelijkenis gaan vertonen met de kennis, die door het model wordt beschreven. Wanneer de totale omvang van het protocol daarbij verdisconteerd wordt, gaan de protocollen van de proefpersonen steeds meer concepten gemeenschappelijk hebben met het model. De omvang van het niet-gemeenschappelijke deel wordt daarbij verhoudingsgewijs steeds kleiner en de concepten die het protocol en het model gemeenschappelijk hebben, worden met een toenemend expertiseniveau steeds meer generiek van aard.

Dit alles lijkt te wijzen op een toenemende compilatie van de kennis. Maar deze resultaten zijn niet doorslaggevend. Een deel van deze toenemende overeenstemming komt namelijk op rekening van de kennisaccumulatie, die in de eerste fasen van de expertiseverwerving plaatsvindt. $\mathrm{Om}$ een uitspraak te kunnen doen over compilatie van de kennis moet ook het type redeneringen dat wordt gevolgd, in de overwegingen worden betrokken. We kunnen pas echt van compilatie van kennis spreken wanneer het aantal redeneringen in de pathofysiologische protocollen, dat identiek is aan een redeneerlijn in het model, toeneemt met een toenemend expertiseniveau en wanneer het aantal verkortingen, indien aanwezig, ook stijgt. Het aantal alternatieve paden, die een grotere mate van detaillering of een eigen idiosyncratische redenering van de proefpersoon weerspiegelen, moet echter afnemen. De resultaten van deze analyses zijn bij elkaar gebracht in Figuur 3.11. 


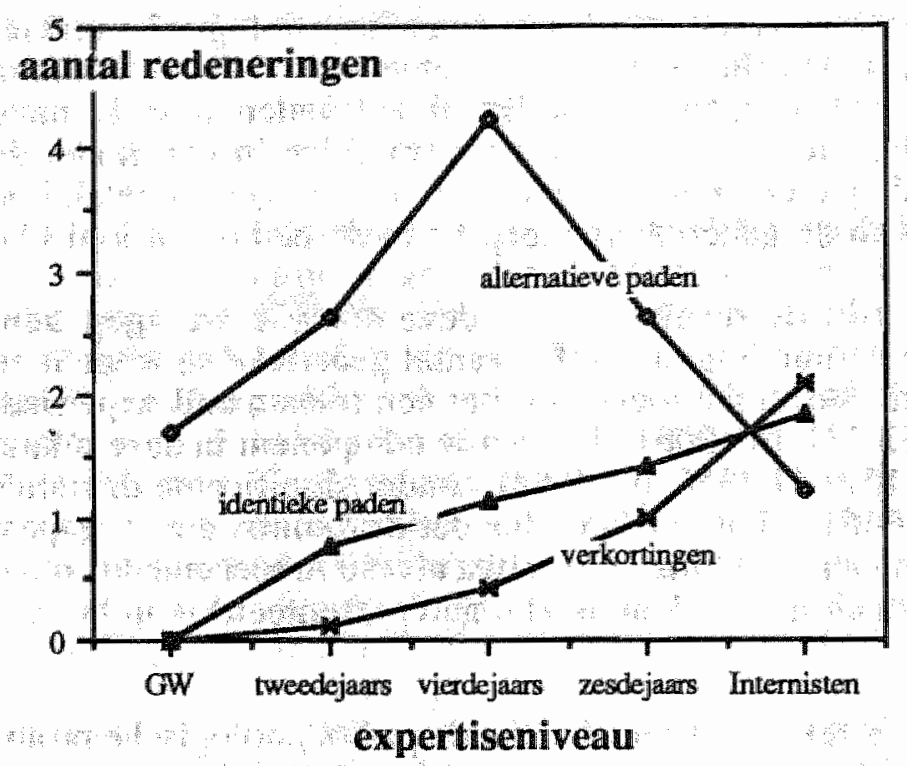

Figuur 3.11 Drie typen redeneringen die zijn gevonden bij de vergelijking tussen de pathofysiologische verklaringen van de proefpersonen en de modelverklaring.

Identieke paden-Zoals in Figuur 3.11 is te zien, neemt het aantal redeneringen in de propositionele netwerken, die identiek zijn aan de redeneringen in het ideaal model toe met een toenemend expertiseniveau $(\mathrm{F}(4,105)=9.4800, \mathrm{p}=.0001$, met alleen een significante lineaire component: $F(1,115)=33.1500, p=.0000$, zonder significante deviaties: $p=$ .2653). Ook blijkt er sprake te zijn van een significant effekt van de toegestane bestuderingstijd. Naarmate deze toenam, nam het aantal identieke redeneringen toe van gemiddeld 0.7 bij 30 seconden bestuderingstijd tot gemiddeld 1.35 bij 3 minuten en 30 seconden $(F(2,105)=3.436$, $p=$ .0359). Er is geen sprake van een differentieel effekt bij de verschillende groepen ten gevolge van een beperking van de bestuderingstijd op het aantal identieke paden $(F(8,105)=.683, p=.7058)$.

Verkortingen - Figuur 3.11 laat ook zien dat het aantal verkortingen stijgt met een toenemend expertiseniveau $(\mathrm{F}(4,105)=14.464, \mathrm{p}=.0001$, met weer alleen een significante lineaire component: $F(1,115)=51.8817$, $\mathrm{p}=.0000$, zonder significante deviaties: $\mathrm{p}=.5502)$. De genoten leestijd heeft geen significante invloed op het aantal verkortingen $(F(4,105)=$ $2.326, p=.1027$ ). Differentiele effekten van een beperking van de leestijd bij de verschillende expertiseniveaus werden ook niet gevonden $(\mathrm{F}(8,105)=1.695, \mathrm{p}=.1082)$.

Alternatieve paden- Het effekt van het expertiseniveau van de proefpersonen is weer duidelijk significant $(F(4,105)=6.323, p=.0001)$. In tegenstelling tot het aantal identieke paden en het aantal verkortingen ver- 
toont het aantal alternatieve paden eerst een toename tot en met het vierde jaar en daarna weer een afname. Dit effekt komt tot uitdrukking in een significante kwadratische component $(F(1,115)=17.6892, p=.0001$, zonder significante afwijkingen: $p=.0958$ ). De propositionele netwerken van de internisten bevatten even veel alternatieve redeneringen om twee concepten met elkaar te verbinden als die van de studenten gezondheidswetenschappen. Beperking van de leestijd heeft echter geen duidelijk effekt op het aantal alternatieve paden $(F(4,105)=2.041, p=135)$, terwijl er ook geen sprake is van een interaktie-effekt tussen beide factoren $(\mathrm{F}(8,105)=1.346, \mathrm{p}=.2291)$

Deze drie analyses tezamen laten zien dat er in de eerste vier jaar over het algemeen genomen sprake is van kennisaccumulatie: het aantal gedetailleerde en idiosyncratische redeneringen neemt over dit trajekt van de expertiseontwikkeling duidelijk toe. Ook het aantal identieke redeneringen en het aantal verkortingen neemt in deze periode toe. Dit kan echter ook worden toegeschreven aan kennisaccumulatie. Na het vierde jaar gaat er vervolgens compilatie van de kennis optreden: het aantal alternatieve redeneringen neemt weer af tot onder het beginniveau, terwijl het aantal identieke redeneringen en verkortingen duidelijk toeneemt. Pas bij de internisten overtreffen de identieke paden en de verkortingen het aantal alternatieve paden. Bij dit niveau van expertise kan er dus gesproken worden van een gecompileerd kennisbestand.

\section{ALGEMENE DISCUSSIE}

Experiment 2 was ontworpen om de theorie te toetsen dat het curvilineaire verband tussen mate van expertise en recall van een medische casus het gevolg is van het gebruik van $\mathrm{kwalitatief}$ verschillende kennisbestanden door personen van een verschillend niveau van expertise. Dit verschil zou hierin bestaan dat de kennis van beginnelingen en intermediates in de geneeskunde geèlaboreerd is in tegenstelling tot de kennis van experts. Bij het oplossen van problemen moet geellaboreerde kennis aktief en bewust worden geaktiveerd. De kennis van experts daarentegen zou door de ervaring in de praktijk gecompileerd zijn, samengebald tot cluster van ziekten en symptomen, en gekoppeld aan de condities waaronder ze toepasbaar is. Hierdoor wordt deze kennis, indien toepasbaar, automatisch en zonder aktief redeneren door een voorgelegd probleem geaktiveerd.

Door dit kwalitatieve verschil in kennis zouden personen van een lager expertiseniveau meer concepten moeten aktiveren wanneer ze een medisch probleem proberen op te lossen. Om dezelfde reden zouden ze meer tijd nodig hebben om een voldoende coherente interne representatie te construeren en zouden ze meer gegevens van het betreffende probleem onthouden. Dezelfde theorie leidt omgekeerd tot de voorspelling, dat wanneer 
proefpersonen van een intermediair expertiseniveau een probleem gedurende een zeer korte tijd mogen bestuderen, zij slechts een heel beperkt deel van hun kennis kunnen aktiveren. Hierdoor zal ook hun recall drastisch afnemen. De kennisaktivatie en de recall van experts zullen echter niet te lijden hebben van een dergelijke bekorting van de bestuderingstijd. Hetzelfde geldt voor beginnelingen. Niet omdat hun kennis kwalitatief gezien verschilt van de kennis van intermediates, maar omdat ze nog heel weinig relevante kennis hebben.

Rasmussen (1986) beschrijft eenzelfde kwalitatieve verandering in de kennis van proces operators van grote en complexe installaties. In de eerste stadia van hun ontwikkeling tot expert passen zij, wanneer zij de oorzaak van storingen in de installatie moeten opsporen, geëlaboreerde kennis toe over de bouw en werking van dat systeem. Met een toenemende ervaring zijn zij meer en meer instaat de oorzaak van die storing als het ware "af te lezen' aan de stand van de meters en indicatoren. De symptomen van een storing in het systeem zijn dan door compilatie van de kennis direkt gekoppeld aan een diagnose.

De resultaten van Experiment 2 waren conform deze voorspellingen. Weer werd een omgekeerd $U$-vorming verband gevonden tussen mate van expertise en hoeveelheid recall 4 . Beperking van de bestuderingstijd leidde tot een drastische daling van de recall van de studentproefpersonen, maar de recall van de internisten werd niet beïnvloed. Ook de hoeveelheid kennis die werd geaktiveerd, vertoonde een omgekeerd $U$-vormig verband met mate van expertise. Verkorting van de bestuderingstijd leidde tot een daling van de hoeveelheid geaktiveerde kennis bij de studentproefpersonen, met name bij de tweedejaars en vierdejaars studenten. Deze resultaten tezamen ondersteunen de theorie dat personen van een hoog expertiseniveau kwalitatief andere kennis toepassen dan personen met een mindere mate van expertise. Een inhoudelijke analyse van de geaktiveerde kennis met behulp van een ideaal verklaringsmodel voor de gebruikte casus leverde een verdere ondersteuning voor de theorie dat dit kwalitatieve verschil in kennis een gevolg is van een leerproces, dat in twee fasen kan worden onderscheiden. De eerste fase, die aangeduid werd als de accumulatiefase,

\footnotetext{
${ }^{4}$ De recallresultaten van Experiment 1 en 2 verschillen in die zin, dat in Experiment 1 gevonden werd dat bij een vrije bestuderingstijd de hoeveelheid informatie die iemand zich van een casus weet te herinneren eerst toeneemt met een toenemend expertiseniveau en in volgende stadia van expertiseverwerving enigszins terugloopt. In Experiment 2 blijkt dat de experts bij een ruime bestuderingstijd zich het minst van de casus herinneren van alle proefpersonen. Wellicht wordt dit verschil in resultaten tussen beide experimenten verklaard door het feit dat in Experiment 1 casus werden gebruikt die in de huisartspraktijk niet vaak voorkwamen zodat huisartsen bij deze casus eigenlijk geen echte experts zijn. De incidentie van bacteriële endocarditis is in de kliniek beduidend groter. Een andere verklaring kan gelegen zijn in het feit dat de casus in Experiment 1 hardop denkend werd bestudeerd. Misschien heeft dit bij de expertgroep geleid tot een intensiever verwerking van de casus, resulterend in een betere recall.
} 
zou resulteren in een geëlaboreerd kennisbestand dat in de daarop volgende fase, de afstemmingsfase, gecompileerd zou worden tot clusters van ziekten en symptomen.

De uitspraken die we naar aanleiding van dit onderzoek doen over de aard van de toepaste kennis en de invloed die verschillen daarin hebben op de interne representatie, die met behulp van die kennis is opgebouwd, suggereren een causaal verband tussen deze entiteiten. De gebruikte onderzoeksmethode is echter niet geëigend om dit causale aspekt ook te bewijzen. Daarvoor zijn experimentele manipulaties van het kennisbestand van de proefpersonen noodzakelijk. Een tweede reden om terughoudendheid te betrachten bij het trekken van conclusies is dat de post hoc methode, die gebruikt is om de toegepaste kennis te onderzoeken, nog onvoldoende empirisch is gefundeerd. De veronderstelling van Patel en Groen (1985) dat met behulp van deze methode de kennis in kaart gebracht kan worden die de proefpersoon gebruikte bij het diagnosticeren van de casus, kan om ten minste twee redenen in twijfel worden getrokken: a) Cooke en McDonald (1986) lieten zien dat de hoeveelheid kennis die, bij gebruik van een direct probe techniek, geproduceerd wordt, sterk afhankelijk is van de formulering van de vraag die gesteld wordt. b) De theorie over de ontwikkeling van de kennis, die in dit hoofdstuk is opgebouwd, zegt dat de basiskennis van experts gecompilleerd is. Dat wil zeggen dat zoekpaden zijn verkort en dat hypothesen omtrent de aandoening van een patiënt automatisch worden geaktiveerd. Dit zou zeer wel kunnen inhouden dat experts bij het representeren van de casus in het geheel geen pathofysiologische concepten aktiveren. De kennis van beginners en intermediates daarentegen is geëlaboreerd en moet, wanneer een student poogt een casus te representeren, bewust redenerend worden geaktiveerd. Dit zou tot gevolg kunnen hebben dat de pathofysiologische protocollen van de beginners en de intermediates wel de kennis representeren die ze daadwerkelijk hebben toegepast, maar dat dit bij de experts niet het geval is. De geringere omvang van de pathofysiologische protocollen van de experts zou in dat geval niet betekenen dat hun kennis meer is gecompileerd, maar dat de basiskennis is vergeten. Deze twee bezwaren tezamen maken het noodzakelijk het gebruik van kennis bij het representeren en oplossen van een casus ook met behulp van een on-line methode te onderzoeken. Dit zullen we doen in Experiment 3 en 4 . Deze worden in Hoofdstuk 4 besproken. 


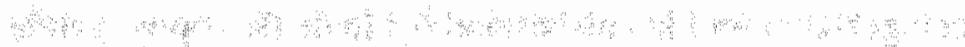

\% मिए

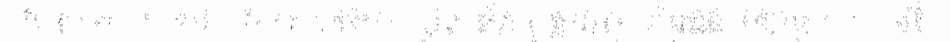

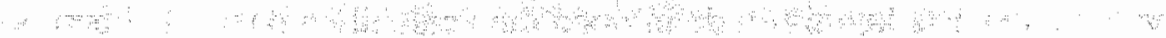

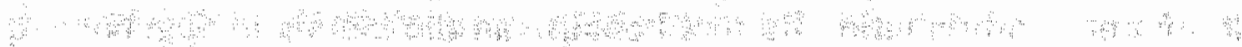

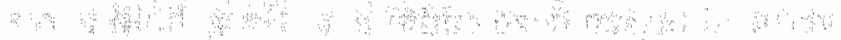

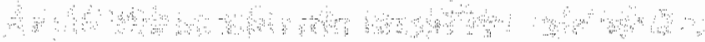

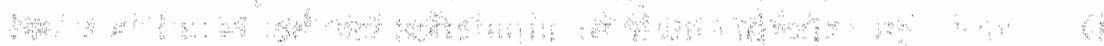

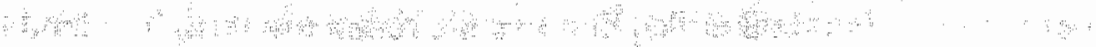

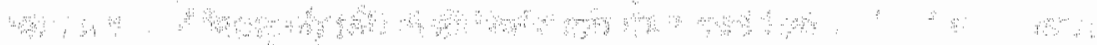

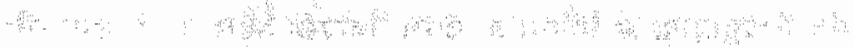

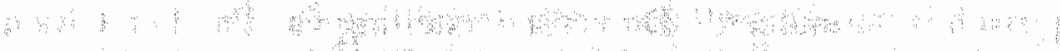

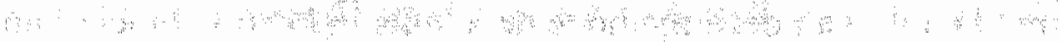

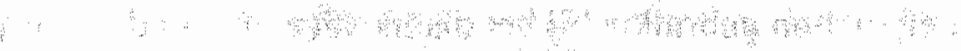

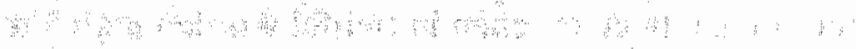

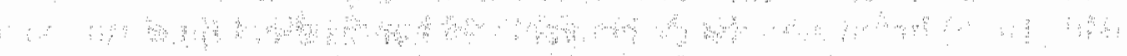

A :

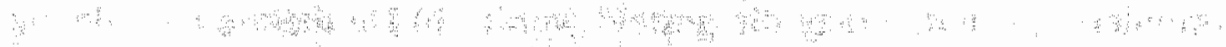

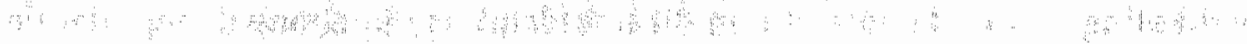

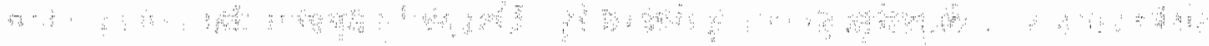

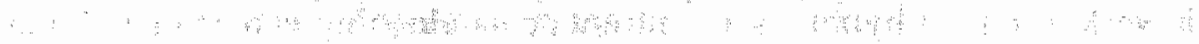

:

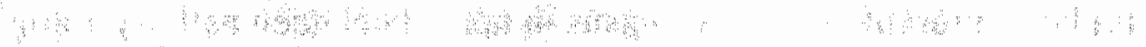

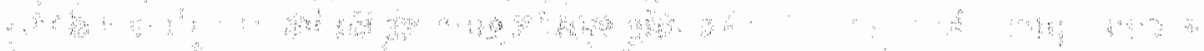

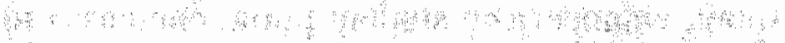

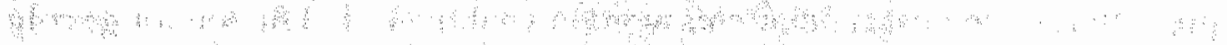

A

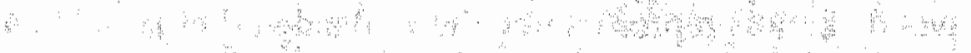

$\therefore$

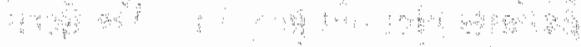

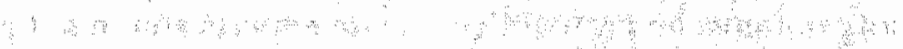

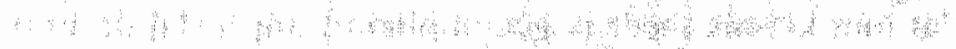

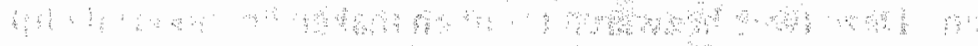

?

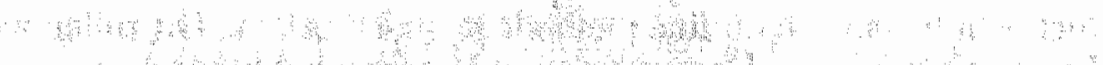

कासे 


\section{HOOFDSTUK 4}

\section{STRUKTURELE KENMERKEN VAN DE KENNIS ${ }_{1}$}

\section{INLEIDING}

In Hoofdstuk 2 zijn we tot de conclusie gekomen dat experts, wanneer zij een probleem oplossen, kwalitatief andere kennis toepassen dan minder ervaren personen. In tegenstelling tot beginners en intermediates in de geneeskunde passen zij gecompileerde kennis toe. Dat wil zeggen: kennis die samengevat is in clusters van symptomen en de bijbehorende diagnose, die als geheel kunnen worden geaktiveerd. Door dit kenmerk van de kennis zijn zij in staat, wanneer zij zeer kort de tijd krijgen om een medische casus te bestuderen en te diagnosticeren, evenveel kennis te aktiveren en

${ }_{1}^{1}$ Delen van de onderzoekingen die in dit hoofdstuk worden gepresenteerd zijn eerder gerapporteerd in Boshuizen, H.P.A., Schmidt, H.G. en Coughlin, L.D. (1987). On-line representation of a clinical case and the development of expertise. Paper presented at the AERA-conference Washington, DC, in Boshuizen, H.P.A., Schmidt, H.G. \& Coughlin, L.D. (1988). On the application of medical basic-science knowledge in clinical reasoning: implications for structural knowledge differences between experts and novices. In: Proceedings of the tenth annual conference of the Cognitive Science Society. Hillsdale, NJ: Erlbaum; en in Boshuizen, H.P.A. en Schmidt, H.G. (in druk). The developing structure of medical knowledge. In: Schmidt, H. G., Nooman, Z., \& Ezzat, E. (Eds.), Innovation in Medical Education: An evaluation of its present status.. New York: Springer. 
evenveel van de casus te reproduceren als wanneer zij ruime tijd tot hun beschikking hebben. In tegenstelling tot de experts zouden beginners en intermediates gebruik moeten maken van geëlaboreerde kennis, die concept voor concept wordt geaktiveerd. De kennisaktivatie en recallprestaties van minder ervaren personen bleken dan ook duidelijk samen te hangen met de beschikbare bestuderingstijd.

In de procesbesturing zal dit ongetwijfeld een goede beschrijving zijn van het leerproces dat daar plaatsvindt. Operators leren de installatie die zij besturen en alles wat daarin fout kan gaan door en door kennen. Door compilatie van de kennis zien zij als het ware aan de uitslag van de meters in welke toestand het systeem verkeert en in geval van storing zien zij ook wat de vermoedelijke oorzaak van die storing is. De compilatie kan daar nog verder gaan. Bepaalde standen van meters leiden automatisch tot het uitvoeren van bepaalde handelingen, waardoor een afwijking of een storing wordt weggeregeld zonder dat er nog een diagnose aan te pas komt, zoals fietsers en automobilisten hun koers, indien nodig, bijsturen zonder dat ze bewust weten dat er sprake is van een afwijking (Rasmussen, 1986).

In het werkterrein van de arts ligt het misschien toch iets anders en lijkt zo'n compilatieproces ontoereikend om de extreme adaptabiliteit en de plasticiteit van het gedrag van experts te verklaren. Ziekten kunnen op heel verschillende manieren tot uitdrukking komen in de symptomen waarmee ze gepaard gaan. Een hartinfarct zal meestal gepaard gaan met pijn op de borst, maar het hoeft niet. De pijn zal meestal uitstralen (naar de schouders, naar de linker arm of naar de kaken), maar het hoeft niet. Het complex van symptomen is bovendien afhankelijk van het stadium waarin het ziekteproces zich bevindt. De mensen die deze ziekten hebben, ervaren de symptomen ervan op verschillende manieren. De ene mens is gevoeliger voor pijn dan de andere en wat voor de ene alleen een vervelend gevoel is, is voor de andere een bijna ondraaglijke pijn. Bovendien verschillen patiënten in de manier waarop ze hun klachten naar yoren brengen. De ene overdrijft, de andere wuift het weg. De ene is heel zakelijk in de communicatie met de arts, terwijl de andere geen hoofdzaak van bijzaak kan onderscheiden of heel emotioneel is. Al deze faktoren zijn van invloed op de informatie die de arts ontvangt en die hij of zij moet gebruiken bij het aktiveren van hypothesen omtrent de vermoedelijke aandoening van de patiënt.

Het is dan ook niet verwonderlijk dat studenten en onervaren artsen in zo'n oerwoud van symptomen soms door de bomen het bos niet meer zien. Welke vlekjesziekte heeft dit kind? Wijzen de symptomen van deze patiënt met pijn rechtsonder in de buik op appendicitis, diverticulitis, ontsteking van de eierstok of op een buitenbaarmoederlijke zwangerschap? Om te kunnen besluiten of een bepaalde hypothese in redelijke mate van toepassing kan zijn op de verschijnselen van de patiënt, moet de arts beschikken over kennis van de natuurlijke variatie van verschijningsvormen van aandoeningen: op welke wijze ze zich kunnen uiten en hoe de symptomatologie kan veranderen afhankelijk van het stadium waarin de aandoe- 
ning verkeert. De arts moet alle variaties op een thema kennen en de omstandigheden waaronder ze zich voor kunnen doen.

Om snel te kunnen onderscheiden tussen meer en minder waarschijnlijke hypothesen is het nodig dat de kennis geconditionaliseerd wordt. Dat wil zeggen dat de kennis gekoppeld wordt aan de condities waaronder ze toepasselijk is. In het geval van de geneeskunde betekent dit laatste dat patiëntkenmerken die met een bepaalde ziekte geassocieerd kunnen zijn, gekoppeld moeten worden aan het gecompileerde cluster dat de symptomen van een ziektebeeld beschrijft. Zulke gegevens zijn onder andere de leeftijdscategorie waarin patiènten met deze aandoening vallen, het geslacht, het geassocieerde risicogedrag zoals roken of het gebruik van harddrugs, of risicofaktoren die met het beroep of de hobby van de patient samenhangen, zoals bij mijnwerkers, landbouwers of duivensportliefhebbers. Bij de patiënt met pijn rechtsonder in de buik maakt het bijvoorbeeld erg veel uit of het een man of een vrouw betreft. Een buitenbaarmoederlijke zwangerschap of een eierstokontsteking is bij een man uitgesloten. Ook de leeftijd van de patiënt is van belang. Appendicitis vindt men in vrijwel alle leeftijdsgroepen, diverticulitis voornamelijk bij ouderen, terwijl buitenbaarmoederlijke zwangerschappen zowel bij kinderen als bij ouderen uitgesloten zijn.

Volgens deze analyse moet de kennis dus in de loop van de ontwikkeling niet alleen worden gecompileerd, maar moeten de gevormde clusters worden verrijkt met andere kennis over de faktoren die van belang zijn bij het ontstaan van ziekten, de uitdrukkingsvormen en de incidentie ervan in verschillende subpopulaties. Een theorie over de ontwikkeling van de medische kennis moet dus de volgende elementen bevatten: a) compilatie tot clusters van symptomen die behoren bij een bepaalde diagnose, b) verrijking van die clusters met kennis omtrent patiëntkenmerken die het verkrijgen van die aandoening in de hand kunnen werken.

Het model van medische expertkennis dat Feltovich en Barrows (1984) beschrijven (weergegeven in Figuur 4.1 ), heeft deze kenmerken. Het is echter een statisch model. Het beschrijft slechts het eindprodukt van het ontwikkelingsproces en niet de stadia waarlangs dat eindprodukt wordt bereikt, noch de mechanismen die daarbij werkzaam zijn.

Feltovich en Barrows veronderstellen dat de kennis van een expert uit meerdere lagen bestaat. Ten eerste is er de laag die de kennis van de medische basisvakken bevat. Dat zijn onder andere de anatomie, de (patho)fysiologie, de immunologie en de farmacologie. Deze vakken beschrijven de normale bouw en het normale funktioneren van het menselijk lichaam en de reakties van dat lichaam op veranderingen en verstoringen. Deze kennis levert de verklaringen voor ziekteprocessen en hun uiterlijke verschijnselen. De kennis in deze laag is gerepresenteerd als in de vorm van een propositioneel netwerk. Wanneer wij naar deze kennislaag refereren dan zullen we spreken van kennis van de medische basisvakken of gemakshalve van (patho)fysiologische kennis. 
De tweede laag die Feltovich en Barrows onderscheiden, bestaat uit wat zij 'illness scripts'2 noemen. Zo'n ziektescript kan opgebouwd worden gedacht uit drie verschillende soorten kennis:

1) Kennis omtrent de omstandigheden die tot een aandoening kunnen leiden. Deze noemen Feltovich en Barrows de 'Enabling Conditions' 3 . Het zijn de predisponerende faktoren, de begrenzende faktoren en de erfelijke faktoren die maken of een persoon met zijn of haar leeftijd en geslacht, sociale en erfelijke achtergrond meer of minder vatbaar is voor een bepaalde ziekte of voor ziekten in het algemeen. Kennis omtrent de Enabling Conditions is ooit tijdens de opleiding verworven door het bestuderen van vakken als epidemiologie, sociologie en psychologie.

2) Kennis omtrent het ziekteproces zelf, de 'Fault'. Dit zijn bijvoorbeeld: trauma, degeneratie, metabole aandoening, infectie, invasieve groei in een weefsel. Het is de gecompileerde kennis afkomstig uit vakgebieden als de pathologie en de pathofysiologie.

3) Kennis over de signalen en symptomen die met de aandoening samenhangen: de 'Consequences'. Tijdens de opleiding zal een student deze zaken vooral leren bij de klinische vakken als de interne geneeskunde of de neurologie.

Beide lagen, kennis van de medische basisvakken en ziektescripts zijn sterk met elkaar geïntegreerd. Een dergelijk ziektescript bevat dus gecompileerde causale (patho)fysiologische kennis die direkt gekoppeld is aan de symptomen van de aandoening. Deze kennis is verrijkt met de kennis omtrent de Enabling Conditions die tot de betreffende Fault aanleiding kunnen geven. Verschillen in Enabling Conditions kunnen bij dezelfde Fault leiden tot andere Consequences. Een griepje kan bijvoorbeeld bij een CARA-patiënt of bij iemand met steenpuisten op een heel andere manier uitwerken dan bij een overigens gezonde jonge volwassene.

2 Een script is een soort schema. Schemata zijn grote complexe kenniseenheden. Ze representeren de eigenschappen die klassen van natuurlijke categoriern typeren. Schemata bevatten een verzameling van attributen en de waarden die die attributen kunnen hebben. Eén van die attributen is de bovengeordende categorie waarvan het schema deel uitmaakt. Zo bevat het schema voor 'huis' onder andere de attributen 'bovengeordende' (met waarde 'gebouw), 'materiaal' (met waarde hout, steen') en 'funktie' ( met waarde 'woning'). Schemata bevatten niet alleen propositionele kennis, maar ook ruimtelijke en andere zintuiglijke kennis. Scripts worden door Anderson (1985) aangeduid als 'event schemas'. Een belangrijk kenmerk yan een script is het causale karakter de gebeurtenissen die door een script worden beschreven, hebben een zekere oorzaak-gevolg relatie. In de literatuur zijn scripts beschreven voor een bezoek aan een restaurant of inkopen doen. De 'illness scripts' van Feltovich en Barrows beschrijven hoe iemand een ziekte opdoet en wat de gevolgen daarvan zijn.

${ }^{3}$ De term Enabling Condition" laat zich, wanneer we niet willen vervallen in onnauwkeurig of wijdlopig taalgebruik, moeilijk vertalen. Daarom is er in dit proefschrift voor gekozen de termen 'Enabling Conditions', 'Fault' en 'Consequences' onvertaald te laten. 


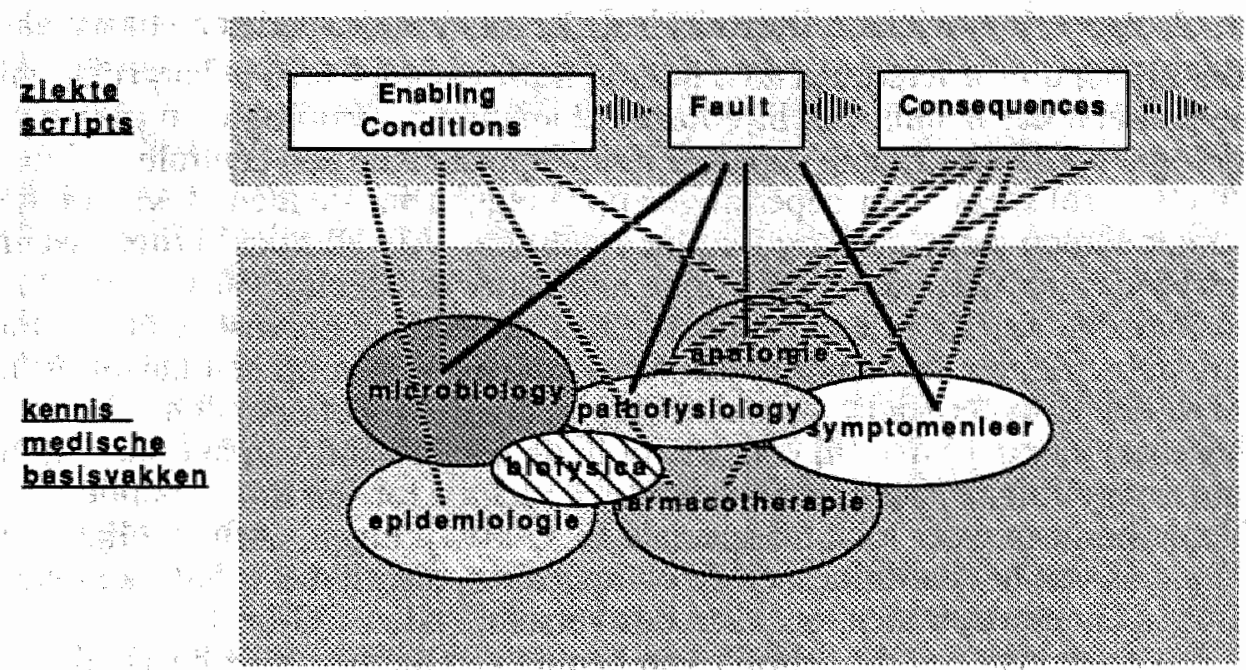

Figuur 4.1 Grafische weergave van het model van Feltovich en Barrows (met toestemming overgenomen van Hobus, 1988)

Daarom nemen we aan dat een arts per ziektebeeld een groot aantal verschillende ziektescripts zal opbouwen, samenhangend met de verschillende typen patiënten die deze aandoening kunnen krijgen en de variaties aan symptomatologieën die mogelijk zijn.

Feltovich en Barrows zijn van mening dat wanneer nu een arts, geconfronteerd met een patiënt, een diagnose stelt, dat niet gezien moet worden als het plakken van een label op een set van symptomen. Dit beeld wordt met name ingegeven door de wijze waarop medische expertsystemen te werk gaan. Nee, een arts aktiveert en instantieert ${ }^{4}$ een ziektescript. Het geinstantieerde ziektescript; de gevormde interne representatie van het probleem, beschrijft hoe de conditie van deze patiënt is ontstaan en het geeft aan wat de belangrijkste mal-en dysfunkties zijn met de daarbij behorende gevolgen, zijnde de huidige symptomen en het te verwachten verloop. Als geen passend script aanwezig is, wordt getracht een interne representatie te construeren die dezelfde elementen bevat: Enabling Conditions, Fault en Consequences. Hierbij wordt gebruik gemaakt van meer generieke scripts en van de onderliggende (patho)fysiologische kennis. In de ogen van Feltovich en Barrows zal het laatste meestal het geval zijn.

${ }^{4} \mathrm{Er}$ is sprake van instantiatie van een ziektescript wanneer de attributen die daarvoor kenmerkend zijn, worden voorzien van de waarden die bij de betreffende patięnt worden gevonden. Het attribuut 'koorts' krijgt bijvoorbeeld de waarde ' $40.4{ }^{\circ} \mathrm{C}$ ', terwijl bij 'leeftijd' '75 jaar' wordt ingevuld. 
Volgens Feltovich en Barrows is de kennis van de medische basisvakken bij het construeren van zo'n interne representatie ${ }^{5}$ heel belangrijk. $\mathrm{Zij}$ nemen aan dat kennis van bijvoorbeeld anatomie, fysiologie en pathofysiologie bij de constructie van de interne representatie een centrale en integrerende rol speelt door beperkingen op te leggen aan de manier waarop de componenten samengevoegd kunnen worden. Als voorbeeld dient weer het hartinfarct waarvan in het vorige hoofdstuk een deeltje van de pathofysiologische kennis in een propositioneel netwerk is gepresenteerd. Het kan gebeuren dat de anamnestische gegevens wijzen op een hartinfaret, terwijl de karakteristieke veranderingen in het ECG niet optreden. Dit verschijnsel kan optreden bij een infarct in de achterwand van het hart. Een ander type infarct, het anteriorinfarct, kan leiden tot een linker bundeltakblock, hetgeen weer leidt tot speciale ECG-afwijkingen. Afhankelijk van de plaats van het hartinfarct en de complicaties, die bij die specifieke lokalisaties kunnen optreden, ontstaan dus verschillende ECG-beelden.

In onze visie zal dit gebruik van kennis van de medische basisvakken alleen optreden wanneer er geen passend script geaktiveerd kan worden. In dat geval wordt een meer generiek script met behulp van de anatomische en pathofysiologische kennis gespecificeerd en geïnstantieerd met de gegevens van de patiënt. Op deze wijze wordt met de componenten 'ziektescriptkennis' en '(patho)fysiologische kennis' een nieuw ziektescript geconstrueerd dat, na gebleken geschiktheid aan het bestand van ziektescriptkennis kan worden toegevoegd.

Een bijzonder kenmerk van het model van Feltovich en Barrows is dat het door de koppeling aan de onderliggende pathofysiologische kennis rekening houdt met de natuurlijk dynamiek van ziekteprocessen. Afhankelijk van de feitelijke aard en omvang van de verstoring en de gezondheidstoestand van de patiënt kan dezelfde aandoening zich op zeer uiteenlopende wijzen manifesteren. Om dezelfde reden kan een aandoening bij de ene patiënt een heel ander verloop hebben dan bij de andere. Verder houdt dit model rekening met de onderlinge samenhang tussen bevindingen. Het transpireren, de angst en de perifere vasoconstrictie, bijvoorbeeld, die bij een hartinfarct worden gevonden, zijn een gevolg van de vegetatieve reakties die bij infarcering optreden (zie Figuur 3.1). Tenslotte biedt dit model de mogelijkheid om voorspellingen te doen over de te verwachten ontwikkeling van de aandoening. Ook hierbij speelt de pathofysiologische kennis een belangrijke rol.

Enabling Conditions, waarvan leeftijd en geslacht heel belangrijke voorbeelden zijn, kunnen vaak direkt, nog voordat er een woord is gezegd, aan de patiënt 'afgelezen' worden. Ze kunnen de arts ook uit vorige

5 Feltovich en Barrows (1984) spreken ook in dit geval over een ziektescript dat geconstrueerd wordt. Scripts en schemata zijn echter bij definitie reeds bestaande, gecompliceerde kennisstrukturen. We nemen daarom, ten behoeve van een éénvormig gebruik van termen in dit proefschrift, hun woordgebruik niet over. 
contacten met de patiënt bekend zijn. Hierdoor kan worden voorspeld dat Enabling Conditions een belangrijke rol spelen bij de aktivatie van ziektescripts door een voorgelegd probleem (Schmidt, Hobus, Patel en Boshuizen, 1987). Verder voorspelt het model van Feltovich en Barrows (1984) dat met de aktivatie van scripts de bijbehorende kennis van de medische basisvakken, die gebruikt zal gaan worden in het verdere diagnostisch proces, zal worden meegeaktiveerd. Anatomische en (patho)fysiologische kennis wordt immers volgens Feltovich en Barrows altijd gebruikt bij het oplossen van een medisch probleem. Hierin zullen experts dus niet verschillen van intermediates. Anders is het wellicht met de kenmerken van die kennis. Door het terugkerend gebruik in de praktijk moet de kennis van de experts meer doelgericht zijn en meer afgestemd op de toepassingscondities.

Deze voorspellingen worden ondersteund door een bevinding van Lesgold, Feltovich, Glaser en Wang (1981). Zij vonden dat experts en intermediates in de radiologie in gelijke mate kennis van de anatomie en pathologie gebruikten bij het diagnosticeren van Röntgen-opnamen van de thorax. De kennis die experts toepasten, was echter uitgebreider, gedetailleerder, relevanter en meer doelgericht dan de kennis die door gevorderden en beginners in dat vakgebied werd gebruikt.

De resultaten van het onderzoek, dat in het vorige hoofdstuk gepresenteerd werd, zijn echter in tegenspraak met de voorspelling. In dit onderzoek zagen we dat studenten geëlaboreerde kennis toepassen om de verschijnselen van een patiënt te verklaren, terwijl experts gecompileerde kennis lijken toe te passen. En ook Patel, Evans en Groen (1988) betwijfelen of het kenmerkend is yoor experts in de geneeskunde, dat zij in sterke mate gebruik maken van kennis van de medische basisvakken bij het oplossen van medische problemen. In een overzicht van onderzoekingen waarin proefpersonen van verschillend expertiseniveau gevraagd werd de onderliggende pathofysiologie van een casus te beschrijven, komen zij tot de conclusie dat experts, in vergelijking met minder ervaren proefpersonen, minder gebruik maken van kennis van de medische basisvakken wanneer zij een diagnose stellen. Als Feltovich en Barrows gelijk hebben dan berusten deze resultaten dus op een artefact. In Hoofdstuk 3 is beschreven waarom deze verklaring niet op voorhand moet worden afgewezen.

Wel mogen we verwachten dat er een verschil zal optreden in het gebruik van Enabling Conditions bij het aktiveren van ziektescripts. Verder zal expertise tot uitdrukking komen in de rijkdom van de kennis omtrent Consequences. Deze zal veel flexibeler zijn dan de kennis van intermediates en van beginners.

Om deze voorspellingen te onderzoeken is Experiment 3 uitgevoerd. Om de valkuilen te vermijden van de post hoc methode, die in Experiment 2 werd gebruikt, is in dit experiment gebruik gemaakt van een on-line methode om de aard van de toegepaste kennis te onderzoeken. Dit onderzoek heeft een sterk exploratief karakter. Er wordt per niveau van expertise slechts één proefpersoon gebruikt. Conclusies omtrent de geformuleerde 
voorspellingen zullen in sterke mate berusten op kwalitatieve analyses van de verzamelde gegevens.

\section{EXPERIMENT 3}

\section{Methode}

Om het gebruik van kennis van de medische basisvakken bij het diagnosticeren van een casus en het psychologische realiteitsgehalte van het begrip 'ziektescript' te onderzoeken, werd een hardop-denk onderzoek uitgevoerd waarbij gebruik werd gemaakt van één van de casus die ook in Experiment 1 was gebruikt, namelijk de typische pancreatitis casus. De hardop-denk methode is een bruikbare methode om de inhoud van denkprocessen en de daarin gebruikte kennis te onderzoeken. We moeten echter in dit experiment bedacht zijn op een aantal faktoren die mogelijk verkeerde conclusies in de hand zouden kunnen werken, namelijk automatisering en overbelasting. Overbelasting van het informatie-verwerkend systeem kan ertoe leiden dat delen van het denkproces niet meer verwoord worden. De geschetste theorie over de ontwikkeling van medische expertise zegt dat expertkennis gekenmerkt wordt door automatisering van deelprocessen. Zo lang zo'n geautomatiseerd proces nog sporen achter laat in het hardop-denk protocol, dan vormt de beperktheid van deze neerslag een aanwijzing yoor een dergelijk automatiseringseffekt. Wanneer dit echter zo ver gaat dat deelprocessen zich volledig buiten de aandacht voltrekken, dan zullen er in het geheel geen neerslagen van te vinden zijn, zodat geen onderscheid gemaakt kan worden tussen volledig geautomatiseerd en afwezig.

Vier proefpersonen namen aan dit onderzoek deel. De minst ervaren proefpersoon, verder aangeduid als de 'Noviet', was een tweedejaars student. Aangezien het onderzoek aan het einde van het studiejaar viel, had deze proefpersoon alle anatomische, fysiologische en basale pathofysiologische kennis verworven die van belang is bij de gebruikte casus. Verder deden twee proefpersonen met tussenliggend expertiseniveau mee, een vierdejaars en een vijfdejaars student. De vierdejaars student, ' $I-1$ ', heeft op het ogenblik van het onderzoek vrijwel het gehele preklinische medisch curriculum van de Rijksuniversiteit Limburg doorlopen. Dit betekent dat hij niet alleen geacht mag worden te beschikken over de relevante pathofysiologische kennis maar ook kennis heeft over het ziektebeeld 'pancreatitis' zelf en het kan differentiëren van andere bovenbuiksklachten. De vijfdejaars student, 'I-2', heeft daarnaast ook relevante praktische ervaring opgedaan in co-schappen interne geneeskunde en huisartsgeneeskunde. De meest ervaren proefpersoon was een huisarts met ongeveer vier jaar ervaring.

Deze proefpersonen kregen de typische pancreatitis casus voorgelegd (zie Hoofdstuk 2). De gegevens van de casus werden sequentieel, op kaart aangeboden. Opdracht aan de proefpersonen was deze casus hardopdenkend door te nemen en een diagnose te formuleren. Deze hardop-denk sessies werden opgenomen op band en later uitgetypt. 


\section{Analyse \\ Casus}

De casusbeschrijving heeft betrekking op een patiënt met chronisch recidiverende pancreatitis met lichte pancreas-insufficiëntie op basis van alcoholmisbruik. Eigenlijk zijn er twee Faults aanwezig. De eerste is verslaving aan alcohol en de tweede is de pancreatitis die als gevolg van het alcoholmisbruik is ontstaan. Andere gevolgen daarvan hebben te maken met de lever en met de eetgewoonten van de patiënt. Twee artsen bepaalden, zo nodig in onderling overleg, welke gegevens in de casus met deze twee processen te maken hadden. Deze gegevens noemen we de scriptgegevens. Vervolgens werd bepaald of deze gegevens Enabling Conditions, dan wel Consequences van de aandoening zijn. De resultaten van deze analyse vindt $u$ in Bijlage 1 .

\section{Analyse van de hardop-denk protocollen}

Eerst werden de hardop-denk protocollen opgesplitst in segmenten. Een ruwe onderverdeling vond plaats op basis van de pauzes in de protocollen. Daarna werden de segmenten waarin sprake was van meerdere mentale 'akties' (zoals hypothesen genereren of eerdere conclusies in twijfel trekken) verder onderverdeeld, zodat ieder protocolsegment geacht mag worden én mentale aktie te vertegenwoordigen. Een voorbeeld van een gesegmenteerd hardop-denk protocol vindt $u$ in Bijlage 4.

Gezien de aard van de vraagstelling die in Experiment 3 wordt onderzocht, richtte de verdere analyse van de protocollen zich op de interne representatie die werd geconstrueerd en de kennis die daarbij werd gebruikt. Daartoe zijn in de protocollen alle segmenten geïdentificeerd waarin de proefpersoon een verband legt tussen een gegeven en een interpretatie, tussen één of meer al dan niet geïnterpreteerd gegeven en één of meer verklarende hypothese (of omgekeerd), of tussen twee verklarende hypothesen. Ook de segmenten waarin de proefpersoon enige casusgegevens met elkaar in verband brengt, zijn hierbij gevoegd. Dit clusteren van gegevens is vaak een eerste stap naar de interpretatie van die gegevens. De verklarende hypothesen kunnen van velerlei aard zijn: een diagnostische hypothese over de aard van de aandoening, een aanduiding van de anatomische lokatie waar de aandoening zijn oorsprong heeft of een aanduiding van het proces dat plaatsvindt. De aldus geselekteerde protocolstappen zijn weergegeven in de vorm van proposities. In Tabel 4.1 vindt u enige voorbeelden van dergelijke proposities.

Om vervolgens het kennisgebruik te onderzoeken werd eerst bepaald welke 'knowledge states' de proefpersonen bereikten tijdens het hardopdenkend oplossen van het probleem (Hassebrock en Prietula, 1986). 'Dit zijn de diagnostische hypothesen die de proefpersonen in de loop van het probleemoplossingsproces hanteren. Vervolgens werd bepaald via welke tussenstappen deze hypothesen werden geaktiveerd of geverifieerd dan wel verworpen. 


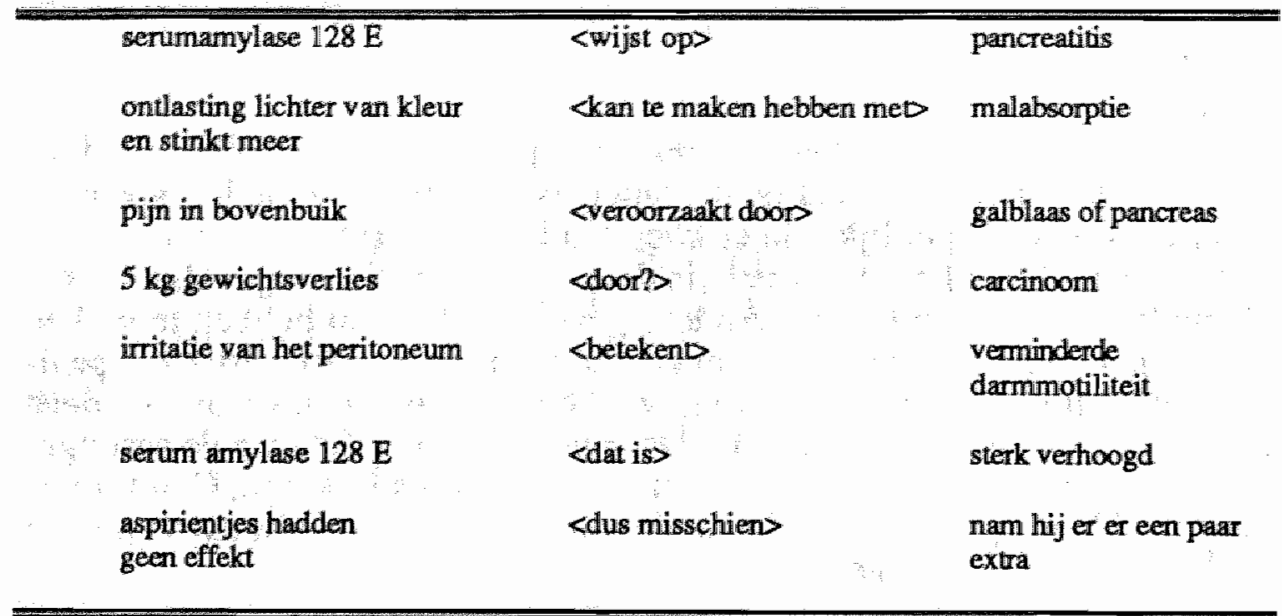

Tabel 4.1 Voorbeelden van proposities ontleend aan de hardop-denk protocollen.

Deze tussenstappen konden bestaan uit interpretaties van gegevens, clusteren van gegevens of uit prediagnostische hypothesen. Deze prediagnostische hypothesen (Gale en Marsden, 1982) zijn globale categorisaties als 'acute situatie', 'niet-pluis' of 'is er slecht aan toe'. De proposities die hierop betrekking hebben, werden samengebracht in causale netwerken waarin de chronologie van de toepassing van de regels gehandhaafd bleef. Deze methode is ontleend aan de frameanalysemethode van Frederiksen en Patel (Patel en Frederiksen, 1984; Patel en Groen, 1986). Deze netwerken zijn weergegeven in Bijlage 5 .

Na deze selektie van proposities bleef er een aantal over die de nietdiagnostische proposities worden genoemd. Deze proposities werden vervolgens door twee beoordelaars in klassen opgedeeld. Opdracht bij deze categorisatie was die proposities bij elkaar te leggen waarin sprake is van vergelijkbare denkstappen.

Op deze wijze werd onderzocht wat de rol is van gegevens omtrent Enabling Conditions bij het aktiveren van ziektescripts, dat wil zeggen bij. het genereren van een hypothese omtrent de aandoening van de patiënt. Verder werd de flexibiliteit van het script onderzocht door na te gaan op welke wijze een hypothese wordt verworpen. Om na te gaan of experts en intermediates even veel kennis van de medische basisvakken gebruiken bij het diagnosticeren van een casus, werd geteld bij hoeveel proposities in de hardop-denk protocollen er sprake is van het gebruik van kennis van de medische basisvakken, hetzij diagnostisch, hetzij niet-diagnostisch gebruikt. Tenslotte werd ook nagegaan of de ziektescripts van minder ervaren proefpersonen dezelfde kenmerken hebben als de ziektescripts van de expert. 


\section{Resultaten}

Karakterisering van de hardop-denk protocollen-De hardop-denk protocollen van de vier proefpersonen verschilden nogal in omvang. Het protocol van proefpersoon $E$ was het langst. Het bevatte 256 segmenten. Het protocol van I-1 was veel korter met de 120 segmenten die het omvatte. Daar tussenin bevinden zich I-2 met 135 segmenten en N met 162 . Aangezien in Experiment 3 slechts één proefpersoon per expertiseniveau is gebruikt, is het niet uit te maken of deze verschillen als subject-gebonden of als groeps-gebonden moeten worden aangemerkt.

Nadat uit deze protocollen de proposities zijn geëxtraheerd waarin de proefpersoon gegevens met elkaar verbond of interpreteerde, bleef er een restant over dat zowel wat betreft de omvang als wat betreft de inhoud per proefpersoon verschilde. Het restant-protocol van de Expert besloeg $45 \%$ van het oorspronkelijke protocol. Deze protocol-elementen zijn heel divers. De proefpersoon schat gegevens in, bijvoorbeeld over duur en verloop in de tijd of de gezinssituatie, zonder direkte interpretaties te vormen, geeft aan waar aanvullende informatie nodig is, gaat in op het belang van de gegevens, stelt prioriteiten, komt met planningen, formuleert verwachtingen, en heeft commentaar op "de arts die hij in de casus aan het werk ziet".

De restantprotocollen van de overige proefpersonen verschillen nogal van elkaar in omvang ( $21 \%$ bij $\mathrm{I}-1,50 \%$ bij $\mathrm{N}$ en $63 \%$ bij $\mathrm{I}-2)$. Bij allen heeft een belangrijk deel van dit restant betrekking op doorvragen op de gegeven informatie: "hoe lang?", "hoe erg?", "wat wordt er precies bedoeld met ...?" Andere opmerkingen betreffen het belang van een gegeven, verwachtingen en commentaar op de casusbeschrijving. Verder vinden we nogal wat opmerkingen die aangeven dat een proefpersoon met een bepaald gegeven niets kan doen : "zegt niks ...". N's protocol bevat bovendien veel opmerkingen die aangeven dat hij te weinig kennis heeft op een bepaald punt: "ik weet niet of, wat, hoe ...". We zien dus dat in de restantprotocollen van de studenten veel verwijzingen voorkomen naar een behoefte aan meer informatie, terwijl de informatie die wordt gegeven vaak niet aansluit bij de kennis.

Hardop-denk proposities- De proposities die uit de hardop-denk protocollen van de proefpersonen gedestilleerd werden, verschilden nogal in aantal en in soort (van gegeven naar hypothese, van hypothese naar gegeven, van gegeven naar gegeven of interpretatie en van hypothese naar hypothese). Cijfers hieromtrent zijn weergegeven in Tabel 4.2. Hierin blijkt dat, afgezien van het protocol van I-2 waaruit 39 proposities werden geëxtraheerd, de protocollen ongeveer evenveel proposities bevatten. Dit aantal varieert van 71 tot 78 . 
Opvallend in deze tabel is dat bij alle proefpersonen bij het merendeel van de proposities een gegeven aan een ander gegeven ${ }^{6}$, een interpretatie of een hypothese wordt verbonden (kolom 1 en 2). Bij de twee meest ervaren proefpersonen ligt de nadruk daarbij op proposities waarin een gegeven aan een ander gegeven of aan een interpretatie wordt gekoppeld, dus op een meer oppervlakkige verwerking van de casus, terwijl bij de twee minder ervaren proefpersonen de nadruk ligt op de proposities waarin een gegeven gekoppeld wordt aan een hypothese. De andere groepen proposities zijn veel minder omvangrijk, maar ook hierin valt weer een tweedeling te maken tussen de proefpersonen met en de proefpersonen zonder praktische ervaring. De twee meest ervaren proefpersonen leggen vaker een verbinding vanuit een hypothese naar een gegeven en minder vaak van de ene hypothese naar een andere. Verder bevat de verzameling proposities van de meer ervaren proefpersonen een grotere hoeveelheid 'overige' proposities. Deze categorie bevat ingewikkeldere proposities, bijvoorbeeld van een gegeven plus een hypothese naar een ander gegeven.

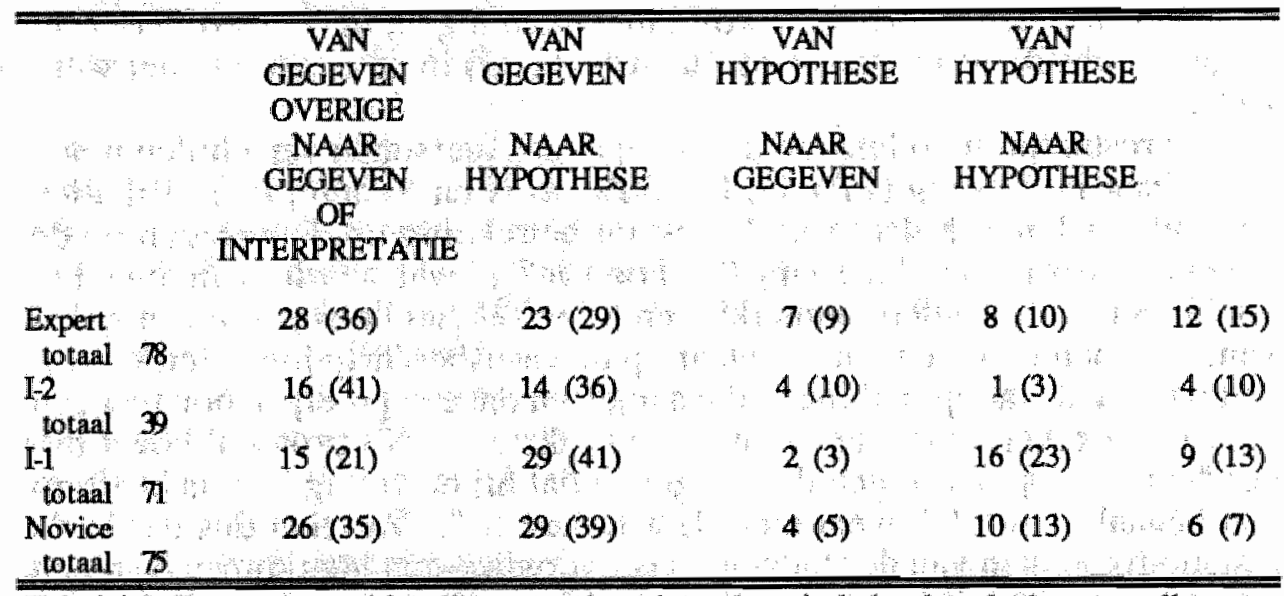

Tabel 4.2 Typen proposities die geéxtraheerd werden uit de hardop-denk protocollen van proefpersonen van verschillende niveaus van expertise. Weergegeven zijn de frekwenties van voorkomen, tussen haakjes weergegeven staan de percentages.

Deze verschillen wekken de indruk dat de Expert en I-2 de gegevens van de casus meer voorbewerken alvorens ze een hypothese uiten over de oorzaak van die gegevens. De anderen redeneren meer direkt van een gegeven naar een hypothese. Deze bevinding sluit aan bij de bevinding in andere domeinen, namelijk dat experts zich meer dan beginners op een probleem oriënteren voordat ze aan de feitelijke oplossing van dat probleem beginnen (Elshout, 1983). Verder worden de hypothesen van de

${ }^{6}$ Hierbij is opvallend dat de gelegde verbindingen tussen gegevens met een toenemend expertiseniveau steeds meer beperkt worden tot die gegevens die deel uitmaken van de geïnstantieerde scripts. Dit wijst op een toenemende selektiviteit. 
jongerejaars proefpersonen vaker dan bij de Expert en I-2 via een andere hypothese geaktiveerd.

Scriptaktivatie- Het model van Feltovich en Barrows voorspelt dat de ziektescripts van de Expert meer Enabling Conditions zal bevatten dan de ziektescripts van de minder ervaren proefpersonen. Verwacht wordt daarom dat de aktivatie van de hypothesen, die de Expert stelt, meer door Enabling Conditions zal gebeuren dan bij de andere proefpersonen. Om deze voorspelling te onderzoeken, werd nagegaan of een nieuwe hypothese geaktiveerd werd door éen of meer Enabling Conditions, door eén of meer Consequences, door een combinatie van deze gegevenstypen of door een andere hypothese. De resultaten van deze analyse zijn weergegeven in Tabel 4.3.

\begin{tabular}{|c|c|c|c|c|}
\hline & Novice & $\mathrm{I}-1$ & $\mathrm{I}-2$ & Expert \\
\hline$\overline{\mathrm{E}} \ldots-\mathrm{F}$ & $2(29)$ & 1 (13) & 1 (14) & - \\
\hline C... $-F$ & $5(71)$ & $6(75)$ & $6(86)$ & \\
\hline $\mathrm{EC} \ldots-\mathrm{F}$ & - & $-:$ & - & $5 \quad(83)$ \\
\hline$F-F$ & - & 1 (13) & - & 1 (17) \\
\hline totaal & 7 & 8 & 7 & 6 \\
\hline
\end{tabular}

Tabel 4.3 Hypotheseaktivatie door de vier proefpersonen met verschillend expertiseniveau.

E....-F: hypothese is geaktiveerd door én of meer Enabling Conditions; C... - F: hypothese is geaktiveerd door én of meer Consequences; EC... - F: hypothese is geaktiveerd door eén of meer Enabling Conditions en Consequences; F - F: hypothese is geaktiveerd door een andere hypothese.

De Expert aktiveert zes diagnostische hypothesen. Deze betreffen de pancreas, lever, maag en hart, die al heel snel worden geuit op basis van het bij elkaar clusteren van een aantal Enabling Conditions en één Consequence. Daama volgen nog de gal (de enige hypothese die voortkomt uit een andere) en veel later de mogelijkheid dat de patiënt wel wat weinig (essentiële) voedingsstoffen binnenkrijgt. Het hypothese-netwerk van I-2 is veel korter. Het omvat zeven hypothesen: lever (op basis van én Enabling Condition), hart, pancreas en maag en verder malabsorptie, shock en paralytische ileus (alle op basis van één Consequence). I-1 aktiveert acht hypothesen. Weer vinden we de lever (op basis van een Enabling Condition), gal, pancreas, hart (op basis van een Consequence) en maag (voortkomend uit een andere hypothese). Verder komen we tegen: peritoneum, atherosclerose en infektie van de parotis (na een Consequence). De Novice tenslotte aktiveert zeven hypothesen: net als bij de overige proefpersonen komen we de pancreas, lever en maag tegen (de laatste op basis van een Enabling Condition). Net als I-1 komt deze proefpersoon met de hypothese 'peritoneum'. En verder komen we tegen: cardiovasculair (op basis van een Enabling Condition) en de bof.

Uit deze analyse komt het beeld naar voren dat aktivatie van een ziektescript bij de Expert op een duidelijk andere wijze plaatsvindt dan bij 
de drie andere proefpersonen. De meeste hypothesen van de Expert worden geaktiveerd door een cluster van Enabling Conditions (vier tot zes) aangevuld met de klacht van de patiënt (een Consequence). Bij de andere proefpersonen vindt de aktivatie plaats door één, hooguit twee Enabling Conditions of Consequences, maar meestal door de Consequences. Aktivatie van een hypothese door een andere hypothese schijnt niet kenmerkend te zijn voor een bepaald niveau van expertise.

Deze resultaten ondersteunen in grote lijnen de hypothese dat de ziektescripts van experts in sterkere mate door Enabling Conditions worden geaktiveerd dan bij minder ervaren proefpersonen het geval is. Wel is opvallend dat het cluster van gegevens op grond waarvan de hypothesen gesteld worden naast vier tot zes Enabling Conditions ook een Concequence, namelijk de klacht, bevat. Wellicht is het zo, dat alleen een set Enabling Conditions een expert nog onvoldoende specifieke informatie biedt om een hypothese reeds serieus in overweging te nemen. Dit lijkt misschien triviaal, maar op het moment dat dat $\mathrm{I}-2$ een hypothese genereert op basis van een Enabling Condition, heeft hij nog geen kennis kunnen nemen van de klacht van de patiënt.

Kenmerken wan ziektescripts-Ziektescripts van experts in de geneeskunde zouden rijk zijn aan Enabling Conditions en een grote flexibiliteit ten aanzien van de Consequences van een aandoening vertonen. Verwacht wordt dat hun ziektescripts op deze aspekten zullen verschillen van de ziektescripts van minder ervarenen. We kunnen ons zelfs afvragen of jongerejaars studenten al volledige ziektescripts hanteren. Ziektescripts zouden immers ten dele voortkomen uit compilatie van de (patho)fysiologische kennis tot clusters van symptomen die bij een ziektebeeld behoren, en ten dele een gevolg zijn van verrijking van die clusters.

De hierboven geschetste resultaten wekken al de indruk dat de scripts van de Expert rijker zijn aan Enabling Conditions. Vanaf het eerste ogenblik worden alle typen attributen van diens scripts geïnstantieerd. Bij de andere proefpersonen is dit niet het geval. $\mathrm{Zij}$ starten ofwel aan de kant van de Enabling Conditions, ofwel bij de Consequences, maar bij voorkeur bij de Consequences. Dit resultaat wil echter nog niet zeggen dat alleen de Expert volledige scripts hanteert. Ook in de loop van het representatieproces kan het geïstantieerde script verder worden gecompleteerd met andere typen gegevens. Daarom werd ook de scriptverificatie onderzocht. De verificatie- en falsificatielinks in de hypothese-netwerken werden op dezelfde wijze geklassificeerd als hiervoor de aktivatie-links. De resultaten van deze analyse vindt $u$ in Tabel 4.4.

Uit deze resultaten blijkt dat de Consequences bij alle proefpersonen de belangrijkste rol spelen in dit verificatieproces. Dat is ook niet zo verwonderlijk, gezien het feit dat dit type gegevens het grootste deel van de casusbeschrijving uitmaakt. Het is echter opvallend dat I-2, die zich bij het aktiveren van scripts niet onderscheidt van zijn medestudenten, bij het verifièren of verder invullen van de eenmaal geaktiveerde scripts uitgebreid gebruik maakt van Enabling Conditions. 


\begin{tabular}{|c|c|c|c|c|}
\hline 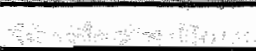 & Novice & $\mathrm{I}-1$ & $\mathrm{I}-2$ & Expert \\
\hline E... $\bar{F}$ & 1 (5) & 2 (4) & $5(31)$ & $9(18)$ \\
\hline C... $-F$ & $9(47)$ & $20(40)$ & $3(19)$ & 17 (35) \\
\hline EC... F & 1 (5) & - & - & 4 (8) \\
\hline $\mathbf{F}-\mathbf{E}$ & $1(5)$ & - & - & (2) \\
\hline $\mathbf{F}-\mathrm{C} \ldots$ & 1 (5) & $6(12)$ & $4(25)$ & (6) \\
\hline $\mathrm{F}-\mathrm{EC} \ldots$ & - & - & - & \\
\hline$F-F$ & & 7 (14) & - & (2) \\
\hline overig & $6(32)$ & $16(31)$ & $4(25)$ & $14(28)$ \\
\hline totaal & 19 & 51 & 16 & 49 \\
\hline
\end{tabular}

Tabel 4.4 Scriptverificatie door de vier proefpersonen met verschillend expertiseniveau. X... - F: script is voorwaarts geverificerd; F - ...X: script is achterwaarts geverifieerd. E...: script is geverifieerd aan én of meer Enabling Conditions; C..: aan eén of meer Consequences; EC...: aan éen of meer Enabling Conditions en Consequences; F - F: script is gelinkt aan een ander script.

Zijn ziektescripts zijn dus rijker wat betreft de Enabling Conditions dan die van de andere studentproefpersonen. Dit blijkt echter niet bij alle hypothesegroepen het geval te zijn. Van de vijf hypothesegroepen die meer dan één link bevatten, zijn er drie die zowel Consequences als Enabling Conditions bevatten. Het betreft hier de hypothesen lever, maag en malabsorptie. De hypothesegroepen pancreas en hart bevatten uitsluitend Consequences. Opvallend bij deze proefpersoon is dat hij zeer lang blijft twijfelen of er nu wel of niet sprake kan zijn van pancreatitis. De hypothese wordt tot twee maal toe verworpen; eenmaal omdat de patiènt er niet ziek uit zou zien en eenmaal omdat de patiënt niet echt koorts heeft. Beide verschijnselen passen niet in het pancreatitisscript van I-2. Zijn kennis van de Consequences van pancreatitis is te rigide om de gevonden verschijnselen te kunnen incorporeren.

Proefpersoon I-1 gebruikt bijna geen Enabling Conditions wanneer hij zijn hypothesen nader onderzoekt. Alleen bij de hypothesegroepen die de gal en de lever betreffen, komt een sporadische Enabling Condition voor. Bij de maag, de pancreas en het peritoneum is dit niet het geval.

De Novice in Experiment 3 laat nog een ander beeld zien. Verhoudingsgewijs maakt hij meer gebruik van Enabling Conditions dan I-1. Het hypothese-netwerk van deze proefpersoon vertoont twee groepen waarin alleen gebruik wordt gemaakt van Consequences: het peritoneum en het spijsverteringskanaal. Verder zijn er twee groepen waarbij zowel Consequences als Enabling Conditions worden gebruikt: cardiovasculaire aandoeningen en de pancreas. En tenslotte is er één groep waarin alleen Enabling Conditions worden gebruikt: de maag. In schril contrast hiermee staat de Expert, wiens ziektescripts in alle gevallen beide soorten gegevens bevatten.

Deze resultaten ondersteunen de hypothese dat ziektescripts van experts in de geneeskunde rijk zouden zijn aan Enabling Conditions. Ook conform de voorspelling is dat de ziektescripts van de minder ervaren 
proefpersonen op dit punt minder rijk lijken te zijn. Proefpersoon I-2 gebruikt wel Enabling Conditions; I-1 en de Novice maken er minder gebruik van. Bovendien geven de resultaten aanwijzingen dat de kennis van I-2, waar het het onderwerp "pancreatitis" betreft, nog inflexibel is.

Gebruik van kennis van de medische basisvakken-In de visie van Feltovich en Barrows (1984) is er in het diagnostisch proces een belangrijke rol weggelegd voor de kennis van de medische basisvakken. Verschillen tussen $\mathrm{E}$ en I-2 in dit soort kennis worden niet verwacht. Ook I-1 verkeert in een zo ver stadium van het preklinisch deel van de opleiding, dat ook hij geacht mag worden in dit opzicht niet van de twee meer ervarenen te verschillen. $N$ daarentegen bezit veel minder kennis. Daarom wordt er verwacht dat er geen verschil gevonden zal worden tussen $E, I-2$ en I-1 in het aantal diagnostische proposities, die de toepassing van anatomische en (patho)fysiologische kennis betreffen. Daarentegen zullen bij proefpersoon $\mathrm{N}$ minder van deze proposities worden gevonden.

Om deze voorspelling te onderzoeken werden in de hypothese-netwerken die delen geïdentificeerd die wijzen op het gebruik van kennis van de medische basisvakken. Dit gebeurde door twee beoordelaars. Deze stukken van de netwerken zijn gearceerd (zie Bijlage 5). In deze netwerkdelen werd het aantal concepten en het aantal 'links' geteld.

In het netwerk van de Novice kunnen drie van zulke delen worden geidentificeerd. Ze omvatten tezamen zes concepten, die deeluitmaken van drie proposities. Het netwerk van I-1 bevat vier stukken waarin duidelijk sprake is van het toepassen van kennis van de medische basisvakken. In deze delen vinden we 19 concepten, die deel uitmaken van 14 proposities. Het netwerk van $\mathrm{I}-2$ bevat geen enkele aanwijzing voor het gebruik van kennis van de medische basisvakken, terwijl we in het netwerk van de Expert één deel kunnen identificeren waarin sprake is van de toepassing van dit type kennis. Het bevat twee concepten en dus één propositie. In Figuur 4.2 zijn deze resultaten weergegeven, uitgedrukt als een proportie van het totale aantal proposities (diagnostische en niet-diagnostische) dat door de proefpersoon wordt gegenereerd.

Deze resultaten zijn niet conform de voorspelling. We zien weliswaar een duidelijke toename in het gebruik van kennis van de medische basisvakken van het Novice-niveau naar het niveau van I-1. Daar staat tegenover dat de Expert en 1-2 geen of bijna geen anatomische en (patho)fysiologische kennis gebruiken bij het construeren van de interne representatie. Daar komt nog bij dat de Expert deze kennis niet gebruikt om delen van een ziektescript met elkaar te verbinden - zoals Feltovich en Barrows veronderstellen - maar om een nieuwe hypothese te genereren. Alleen het netwerk van proefpersoon I-1 bevat delen waarin duidelijk netwerkonderdelen aan elkaar worden gelinkt en op elkaar afgestemd. Deze resultaten pleiten dus tegen de veronderstelling van Feltovich en Barrows (1984). 


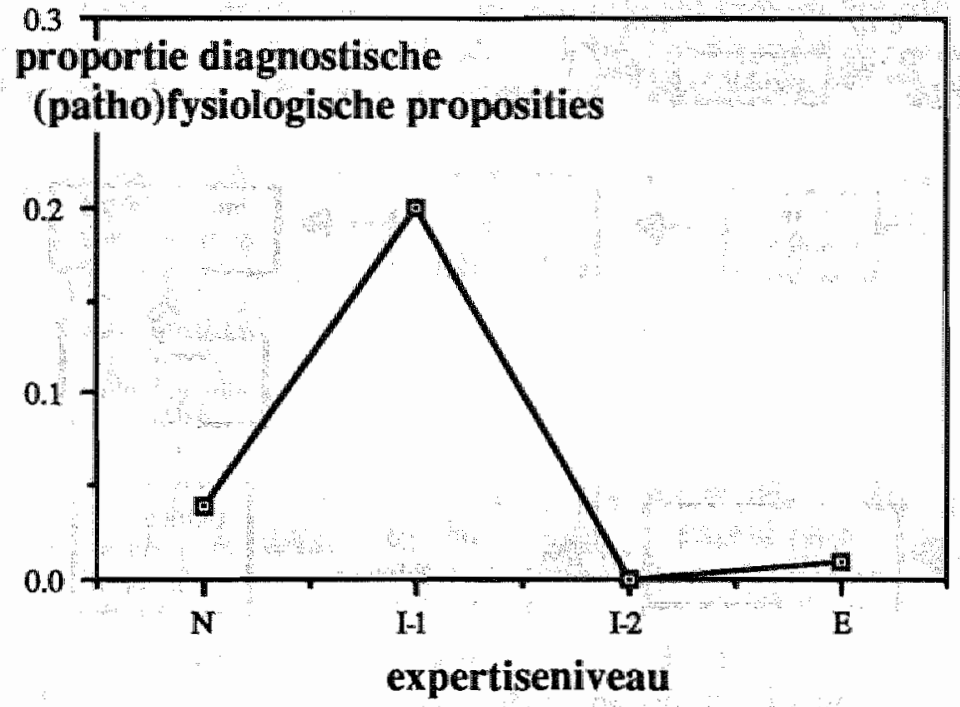

Figuur 4.2 Proportie diagnostische proposities die betrekking hebben op de toepassing van kennis van de medische basisvakken door vier proefpersonen van verschillend expertiseniveau.

Niet alleen in de hypothese-netwerken komt het gebruik van kennis van de medische basisvakken tot uitdrukking. Ook in de niet-diagnostische proposities blijkt het gebruik van kennis van de medische basisvakken. Daartoe hebben twee beoordelaars deze proposities ingedeeld in groepen waarin sprake is van gelijke mentale operaties.

Uit deze analyses blijkt dat de verzameling niet-diagnostische proposities van de Novice $(n=49)$ voornamelijk interpretaties van gegevens bevat (39) die berusten op fysiologische (9) of pathofysiologische (30) kennis (een paar voorbeelden van deze proposities zijn weergegeven in Figuur 4.3). Meer dan de helft van deze proposities was onjuist.

Dertien van de 14 niet-diagnostische proposities van proefpersoon I-1 kunnen worden aangemerkt als interpretatiestappen. Tien daarvan zijn gebaseerd op kennis van de medische basisvakken.

Bij proefpersoon I-2 wordt ook weer de hoofdmoot van de niet-diagnostische proposities $(n=12)$ gevormd door interpretatiestappen (11). Opvallend daarbij is echter dat vier van deze interpretaties een 'gewone' verklaring geven voor een casusgegeven, namelijk 'pijn'. De andere zeven betreffen kennis van de medische basisvakken.

In de niet-diagnostische proposities van de Expert tenslotte $(n=24)$ vinden we 15 interpretaties. Hiervan zijn er vier gebaseerd op kennis van de medische basisvakken, terwijl er 11 in de sfeer van de Enabling Conditions liggen. 


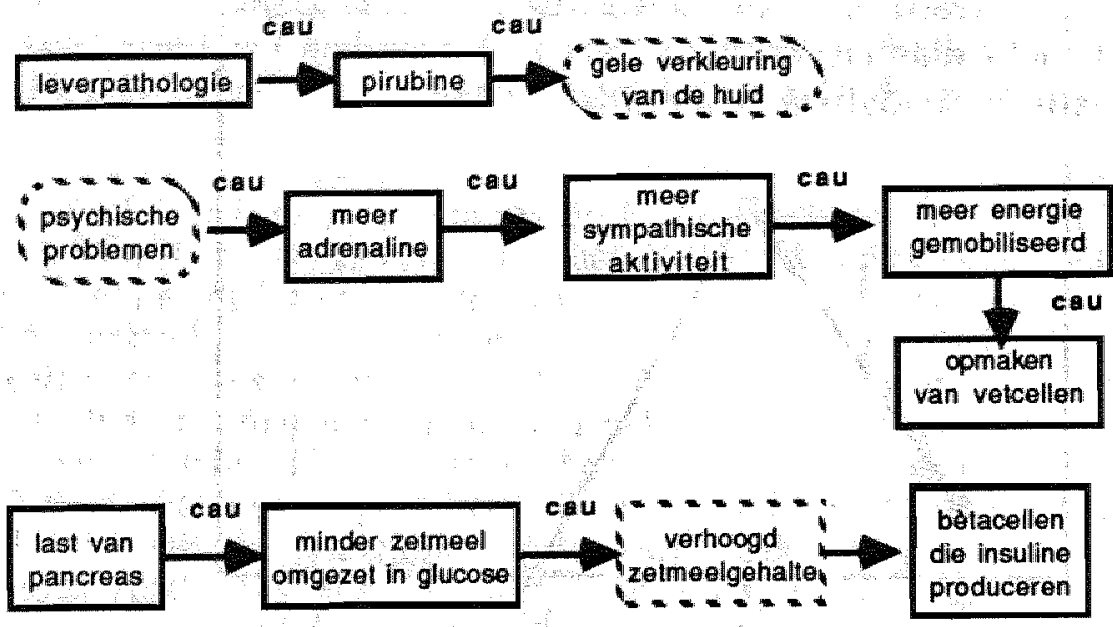

Figuur 4.3 Enige niet-diagnostische proposities van pp N.

Bij alle proefpersonen vormen de interpretaties dus de grootste groep. Maar de proportie interpretaties die gebaseerd zijn op pathofysiologische kennis neemt af met een stijgend expertiseniveau (zie Figuur 4.4). De resterende interpretaties bij I-2 liggen op het gebied van de 'gewone' verklaringen, hetgeen aangeeft dat deze proefpersoon aktief onderscheid maakt tussen klinisch relevante en klinisch niet-relevante bevindingen. Bij de Expert worden de overige interpretaties gevormd door de identificatie van Enabling Conditions.

proportie niet-diagnostische

(patho)fysiologische proposities

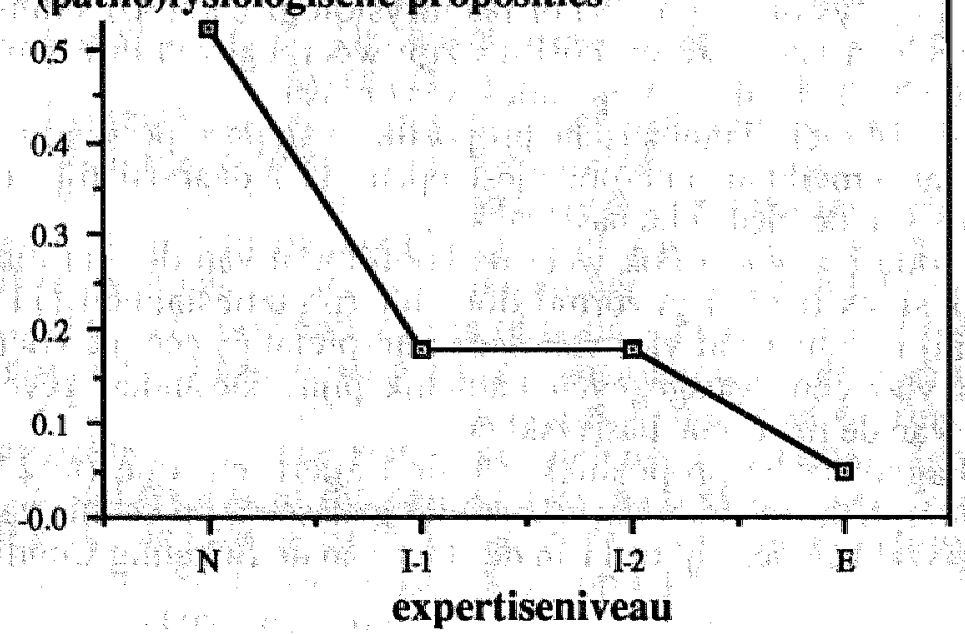

Figuur 4.4 Proportie niet-diagnostische proposities die betrekking hebben op de toepassing van kennis van de medische basisvakken door vier proefpersonen van verschillend expertiseniveau. 
Uit deze resultaten blijkt dus dat de rol van de kennis van de medische basisvakken afneemt bij de constructie van het niet-diagnostische gebruikte deel van de probleemrepresentatie wanneer het expertiseniveau toeneemt.

\section{Discussie}

De resultaten van Experiment 3 vormen een gedeeltelijke ondersteuning van de ideeën van Feltovich en Barrows omtrent de kenmerken en de struktuur van de kennis van medische experts. Alleen de Expert aktiveert ziektescripts (in vijf van de zes gevallen) op basis van een conglomeraat van Enabling Conditions en é́n Consequence, namelijk de klacht die de patiënt heeft geuit. De minder ervaren proefpersonen gebruiken bijj voorkeur Consequences om een ziektescript te aktiveren. Als zij toch zo'n script met behulp van Enabling Conditions aktiveren, dan is dat meestal op grond van slechts één gegeven van deze soort. Dit resultaat ondersteunt het vermoeden dat de ziektescriptkennis van de Expert verrijkt is met kennis omtrent de relevantie van patiëntenkenmerken, in tegenstelling tot de ziektescripts van de studentproefpersonen. In het verdere diagnostisch proces blijkt ook I-2 ruim gebruik te maken van Enabling Conditions om scripts te verifiëren of te falsificeren. Dit resultaat suggereert dat ook de ziektescripts van I-2 op deze wijze zijn verrijkt, maar dat ze nog niet met behulp van (een conglomeraat van) deze gegevens kunnen worden geaktiveerd.

Verder werd voorspeld dat de kennis van de expert rond de Consequences van een aandoening meer flexibel is. Een aanwijzing voor de juistheid van deze hypothese wordt gevormd door de bevinding dat I-2 tot twee maal toe éen en dezelfde hypothese verwerpt, omdat de gegevens van de patiënt niet passen bij zijn script. De koorts is bijvoorbeeld in zijn ogen te laag, dus kan er geen sprake zijn van pancreatitis.

Deze resultaten lijken erop te wijzen dat alleen bij de Expert sprake is van een kant-en-klaar script, dat zonder modificaties van toepassing is op de voorgelegde casus. Na enige integrerende voorbereidingen wordt een aantal mogelijke scripts geaktiveerd, die vervolgens aan de rest van de gegevens worden getoetst. De andere proefpersonen aktiveren ook al snel hypothesen over mogelijke oorzaken van de aandoening van de patiënt. Hun scripts worden echter in eerste instantie slechts met én gegeven geïstantieerd. Ook de verdere instantiatie van de scripts verloopt, door de inflexibiliteit van de kennis, niet probleemloos. Wel is duidelijk dat met een toenemend expertiseniveau de interne representatie van de casus steeds vaker zowel Enabling Conditions als Consequences van de Fault gaat omvatten. Dit zou erop kunnen wijzen dat de meer ervaren student wel generieke ziektescripts tot zijn beschikking heeft, maar nog niet het gespecialiseerde script dat op deze casus van toepassing is.

Verder is essentieel in de theorie over scripts en schemata dat de kennis die hiermee gerepresenteerd is, in zijn geheel geaktiveerd wordt. Dat betekent dus dat als een hypothese gesteld wordt, de arts of de student automatisch weet welke verschijnselen er verder gevonden moeten worden, wil 
er inderdaad sprake zijn van de veronderstelde aandoening. De Expert blijkt als enige verwachtingen te genereren (in vier niet-diagnostische proposities) over mogelijke andere verschijnselen die de patiënt zal vertonen. De andere proefpersonen geven wel aan dat bevindingen aansluiten bij hun verwachtingen. Dit blijkt uit uitspraken als "dat vind ik niet vreemd" of "dat kun je wel verwachten". Dat wil echter nog niet zeggen dat ze dit ook echt verwacht hadden, misschien kijken ze wel nergens vreemd van op.

Deze resultaten suggereren dat de Expert bij het oplossen van deze casus gebruik maakt van rijke, flexibele ziektescripts, hetgeen conform de theorie van Feltovich en Barrows is. De ziektescripts van de minder ervaren proefpersoon I-2 lijken nog minder rijk en flexibel te zijn. En verder is het twijfelachtig of de twee andere proefpersonen al over de ziektescripts beschikken die toepasbaar zijn bij het diagnosticeren van deze casus.

De resultaten die betrekking hebben op de andere kennislaag, die Feltovich en Barrows onderscheiden, zijn heel wat minder gunstig voor hun theorie. Feltovich en Barrows nemen aan dat kennis van de medische basisvakken een integrerende rol speelt bij het construeren van een interne representatie van een casus, omdat de bouw en het funktioneren van het menselijk lichaam beperkingen opleggen aan de manier waarop patiëntkenmerken en symptomen van een aandoening samen kunnen voorkomen. Deze hypothese leidt tot de voorspelling dat met name de Expert anatomische en (patho)fysiologische kennis zal gebruiken in het diagnostisch proces.

Uit de resultaten blijkt dat de Expert inderdaad gebruik maakt van zijn kennis van de medische basisvakken, zowel in diagnostische als in nietdiagnostische zin. Dit blijkt echter niet kenmerkend te zijn voor de Expert. Integendeel, de minder ervaren proefpersonen blijken meer gebruik te maken van (patho)fysiologische kennis. En verder is opvallend dat alleen I-1 zijn basisvakkenkennis aanwendt op een manier die Feltovich en Barrows beschrijven. Hij gebruikt deze kennis duidelijk om scriptelementen met elkaar te verbinden.

In Figuur 4.5 zijn de proporties diagnostisch gebruikte en niet-diagnostisch gebruikte (patho)fysiologische proposities samengebracht. Duidelijk blijkt dat er sprake is van een afnemend aandeel van het gebruik van kennis van de medische basisvakken. Deze afname, gevoegd bij de funktie die deze kennis bij deze proefpersonen in de diagnostiek blijkt te hebben, suggereert dat het model van Feltovich en Barrows op dit punt onjuist is.

Deze resultaten suggereren dat de bevindingen die in Hoofdstuk 3 werden gepresenteerd niet op een artefact berusten. Dit geldt ook voor de resultaten die Patel, Evans en Groen (1988) beschrijven. De vraag die zich dan opdringt, luidt: Wat is er gebeurd met de kennis van de medische basisvakken? 


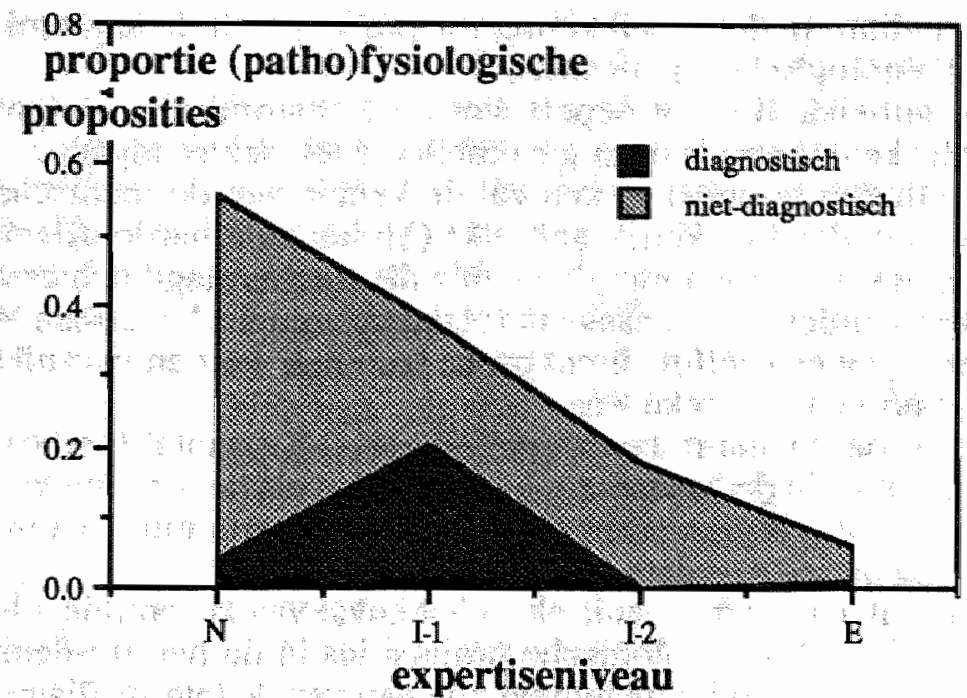

Figuur 4.5 Proportie proposities die het diagnostisch en niet-diagnostisch gebruik van kennis van de medische basisvakken laten zien bij het construeren van de interne representatie van de voorgelegde casus.

De eerste mogelijkheid is dat deze kennis geheel vergeten en rudimentair geworden is. Ackermann en Barbichon (1963) beschrijven een onderzoek bij chemici en electrotechnici die al jarenlang werkzaam zijn in de industrie, waaruit blijkt dat zij heel veel vergeten zijn van de basisvakken die ze tijdens hun opleiding hebben bestudeerd en beheerst.

Een andere mogelijkheid is dat de kennis van de basisvakken inert is geworden (Bransford, Sherwood, Vye en Rieser, 1986). Dit zou betekenen dat de kennis nog wel aanwezig is, maar een zo algemeen-geldend karakter heeft, dat deze in toepassingssituaties niet geaktiveerd wordt (de 'context-free, principled knowledge', waar Leinhart (1987) over spreekt).

De laatste mogelijkheid is dat de bedoelde kennis in het expertstadium dermate gecompileerd en geintegreerd is in de ziektescripts die worden toegepast, dat de toepassing ervan automatisch verloopt. Hierdoor zouden er geen sporen worden nagelaten in het hardop-denk protocol (Ericsson en Simon, 1984). Om deze drie mogelijke verklaringen te onderzoeken werd Experiment 4 uitgevoerd.

\section{EXPERIMENT 4}

In Experiment 4 zullen dus drie hypothesen worden onderzocht ter verklaring van de bevinding dat experts minder kennis van de medische basisvakken toepassen dan mensen van een intermediair niveau van medische expertise. Het zijn de volgende drie hypothesen:

1) $\mathrm{Na}$ een zeker stadium in de ontwikkeling tot expert wordt de anatomische en (patho)fysiologische kennis rudimentair. 
2) Na een zeker stadium in de ontwikkeling tot expert wordt de anatomische en (patho)fysiologische kennis inert.

3) Gedurende de ontwikkeling tot expert wordt de anatomische en (patho)fysiologische kennis steeds meer gecompileerd tot ziektescripts.

Om deze hypothesen te onderzoeken zal de kennis van de medische basisvakken, die men daadwerkelijk gebruikt (blijkens de hardop-denk protocollen), vergeleken worden met de kennis die desgevraagd achteraf ge(re)aktiveerd kan worden om de casus in (patho)fysiologische termen te verklaren. Hiervoor zal een zelfde direct probe techniek worden gebruikt als waarvan in Experiment 2 sprake was.

In het geval van rudimentaire kennis zullen zowel het aantal (patho)fysiologische proposities in de hardop-denk protocollen als de omvang van de post hoc pathofysiologische verklaringen van de experts minder omvangrijk zijn dan van de intermediates.

Zowel in het geval van inerte kennis als in het geval van gecompileerde kennis zal het aantal (patho)fysiologische proposities in de hardop-denk protocollen van de experts minder uitgebreid zijn dan van de intermediates, terwijl de omvang van hun pathofysiologische verklaringen niet zal verschillen. Als er echter sprake is van inerte kennis dan moeten we verwachten dat er geen enkele overlap zal bestaan tussen de kennis die wordt toegepast in de pathofysiologische verklaringen en de kennis die in de hardop-denk protocollen wordt toegepast. Wordt er daarentegen tijdens het oplossen van het probleem gebruik gemaakt van gecompileerde kennis van de medische basisvakken, dan zal er sprake zijn van een overlap tussen de inhoud van de pathofysiologische proposities, die ontleend kunnen worden aan de hardop-denk protocollen en de inhoud van de pathofysiologische verklaringen. Verwacht kan worden dat in het geval van compilatie een stijgend expertiseniveau gepaard zal gaan met een toenemende overlap tussen de inhoud van de pathofysiologische proposities uit de hardop-denk protocollen en van de pathofysiologische verklaringen.

\section{Methode}

Aan Experiment 4 namen 20 proefpersonen deel. Zes proefpersonen waren tweedejaars studenten, die evenals de Novice in Experiment 3 aan het einde van het tweede studiejaar werden onderzocht. Vier proefpersonen waren van het zelfde niveau als proefpersoon I-1, namelijk aan het einde van het vierde studiejaar, Verder namen vijf vijfdejaars proefpersonen (van het I-2 niveau) deel, die hun co-assistentschap interne geneeskunde en huisartsgeneeskunde hadden doorlopen. De vierde groep bestond uit vijf huisartsen met ongeveer vier jaar ervaring.

Deze proefpersonen kregen dezelfde casus voorgelegd als de proefpersonen in Experiment 3. Ook de afname verliep op dezelfde wijze, met dat verschil dat de proefpersonen, nadat ze de casus hardop-denkend hadden doorgenomen en een diagnose hadden gesteld, de vraag kregen voorgelegd de bevindingen in de casus in pathofysiologische termen te verklaren. 


\section{Analyse}

De hardop-denk protocollen werden geanalyseerd op het gebruik van kennis van de medische basisvakken. Daartoe werden, op dezelfde wijze als dat gebeurde in Experiment 3, uit deze hardop-denk protocollen de proposities geëxtraheerd waarin de proefpersoon blijk gaf van het gebruik van kennis. Deze werden vervolgens onderscheiden in proposities waarin wel en waarin geen anatomische en (patho)fysiologische kennis werd gebruikt. Vervolgens werd de hoeveelheid gebruikte (patho)fysiologische kennis bepaald door het aantal geëxtraheerde proposities te tellen dat daarop betrekking had. De verzameling proposities van elke proefpersoon zullen we in het vervolg aanduiden met de term 'propositieset'. Eén bandopname was zo gestoord dat er geen transcriptie van verkregen kon worden. Daarom zijn de analyses van de hardop-denk protocollen gebaseerd op de gegevens van 19 proefpersonen.

De pathofysiologische verklaringen werden geanalyseerd met een methode die beschreven is door Patel en Groen (1986). Patel en Groen deelden deze verklaringen op in proposities, bestaande uit twee concepten die verbonden worden door een relatie. Vervolgens werden deze verzamelingen proposities omgezet in een causaal netwerk. In deze pathofysiologische netwerken werden het aantal concepten en en het aantal verbindingen tussen de concepten geteld.

Tenslotte werd de mate van overlap tussen de (patho)fysiologische proposities, die ontleend zijn aan de hardop-denk protocollen en de pathofysiologische netwerken bepaald. Daartoe werd vastgesteld welke concepten in de propositiesets identiek waren aan de concepten in de pathofysiologische netwerken. De mate van overlap werd gedefinieerd als de proportie concepten in het netwerk die identiek zijn aan enig concept dat in de propositieset van de proefpersoon voorkomt ${ }^{7}$.

\section{Resultaten}

Hardop-denk protocollen-De hoeveelheid pathofysiologische kennis, die blijkens de hardop-denk protocollen wordt toegepast bij het diagnosticeren van de casus, hangt duidelijk samen met verschillen in expertiseniveau $(F(3,15)=4.102, p=.026)$. Er was echter sprake van tamelijk grote individuele verschillen in omvang van de hardop-denk protocollen en van het totale aantal kennisproposities daarin. Met deze individuele verschillen werd rekening gehouden door hoeveelheid toegepaste pathofysiologische kennis uit te drukken als proportie van de totale hoeveelheid toegepaste kennis $(F(3,15)=3.1993, p=.0538)$. De resultaten van deze analyse vindt $u$ in Figuur 4.6. Duidelijk blijkt dat er een top ligt bij de I-1 groep, bij wie bijna de helft van de kennis, die wordt toegepast in de

\footnotetext{
${ }^{7}$ Theoretisch gezien zou de matchingsprocedure even goed kunnen starten bij de concepten die we achtereenvolgens in de hardop-denk proposities tegenkomen. Eén en hetzelfde concept kan echter in meerdere proposities fungeren. Aangezien deze methode zou leiden tot dubbeltellingen, is aan de andere methode de voorkeur gegeven.
} 
hardop-denk protocollen, bestaat uit kennis van de medische basisvakken. Nadere analyse laat zien dat alleen de derde machtscomponent in het gevonden effekt significant is $(\mathrm{F}(1,15)=6.1245, \mathrm{p}=.0258)$. De $\mathrm{p}$-waarden van de overige componenten zijn groter dan 10 . Dit resultaat repliceert dus de bevinding dat experts, in tegenstelling tot intermediates, vrijwel geen kennis van de medische basisvakken toepassen bij het diagnosticeren wan een medisch probleem.

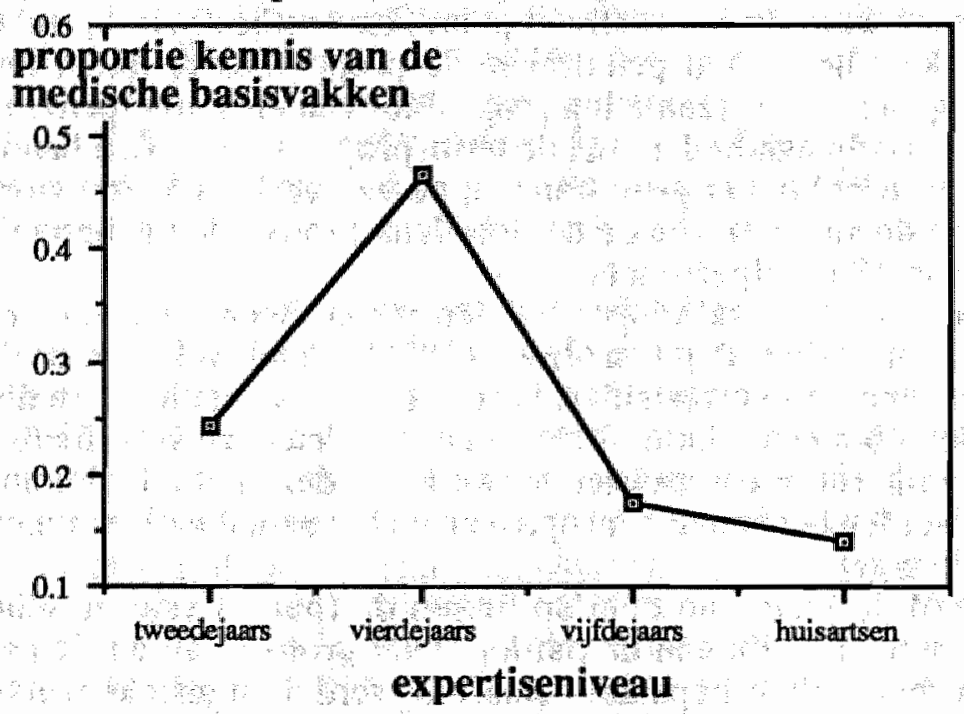

Figuur 4.6 De hoeveelheid anatomische en (patho)fysiologische kennis die in de hardopdenk protocollen gebruikt wordt bij het diagnosticeren van een medische casus, gecorrigeerd voor de totale hoeveelheid toegepaste kennis.

Pathofysiologische netwerken-Zowel het aantal concepten ( $\mathrm{F}(3,16)=$ $3.811, \mathrm{p}=.031)$ als het aantal verbindingen tussen concepten $(\mathrm{F}(3,16)=$ $3.567, \mathrm{p}=.0379$ ) blijken samen te hangen met het niveau van expertise. Polynoomanalyse laat zien dat bij beide variabelen alleen de lineaire component significant is (concepten: $F(1,16)=10.8746, p=0045$ zonder significante afwijkingen van lineariteit $(p=7602)$, verbindingen: $F(1,16)=$ $10.4434, p=.0379$ ook zonder significante afwijkingen $(p=.8800)(z i e$ Figuur 4.7).

Dit resultaat laat zien dat de kennis van de medische basisvakken bij de experts niet rudimentair is geworden. Integendeel, er blijkt sprake te zijn van een continue toename met een stijgend expertiseniveau. De pathofysiologische verklaringen van de experts zijn het meest omvangrijk. Hiermee is Hypothese 1 verworpen. 


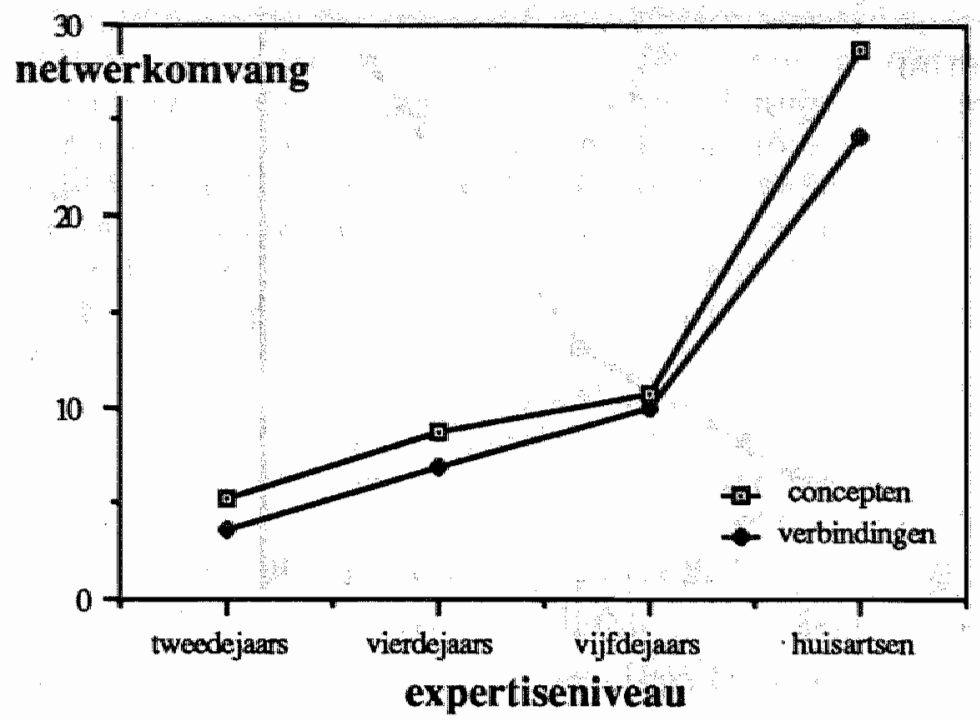

Figuur 4.7 Omvang van de pathofysiologische netwerken per niveau van expertise, uitgedrukt in het aantal concepten en het aantal verbindingen tussen die concepten.

Mate van overlap-De twee resterende hypothesen sluiten elkaar in zekere zin uit. Als kennis van de medische basisvakken in de loop van het ontwikkelingsproces tot expert meer en meer gecompileerd wordt, dan mogen we verwachten dat de overlap tussen de kennis die wordt toegepast in het diagnostisch proces en de kennis die feitelijk beschikbaar is, zal toenemen. Als de kennis daarentegen inert is geworden, dan zal deze overlap (na een aanvankelijke stijging) gelijk blijven, dan wel een daling gaan vertonen. Om deze hypothesen te onderzoeken werden de proposities die geabstraheerd waren uit de hardop-denk protocollen gematched tegen de pathofysiologische netwerken, die geconstrueerd waren op basis van de pathofysiologische verklaringen. De overlap tussen de propositieverzameling en het pathofysiologisch netwerk werd uitgedrukt in de proportie gemeenschappelijke concepten (zie Analyse).

Uit deze analyse bleek dat de mate van overlap monotoon toenam met een stijgend expertiseniveau $(F(3,15)=19.887, p=.0000)$. Bij de novicen bedroeg de overlap nog slechts $14.9 \%$. Deze stijgt tot $56.2 \%$ bij de experts. De hiermee geassocieerde lineaire component is als enige significant $(F(1,15)=57.9032, p=.0000$, waarbij geen significante afwijkingen van lineariteit optreden: $p=4357$ ). De resultaten die op deze manier werden gevonden, zijn weergegeven in Figuur 4.8.

Deze resultaten wijzen er dus op dat de kennis van de medische basisvakken van de expert niet inert is geworden. In plaats daarvan leiden deze resultaten ons tot de conclusie dat experts bij het oplossen van een medische casus gebruik maken van gecompileerde anatomische en (patho)fysiologische kennis. 


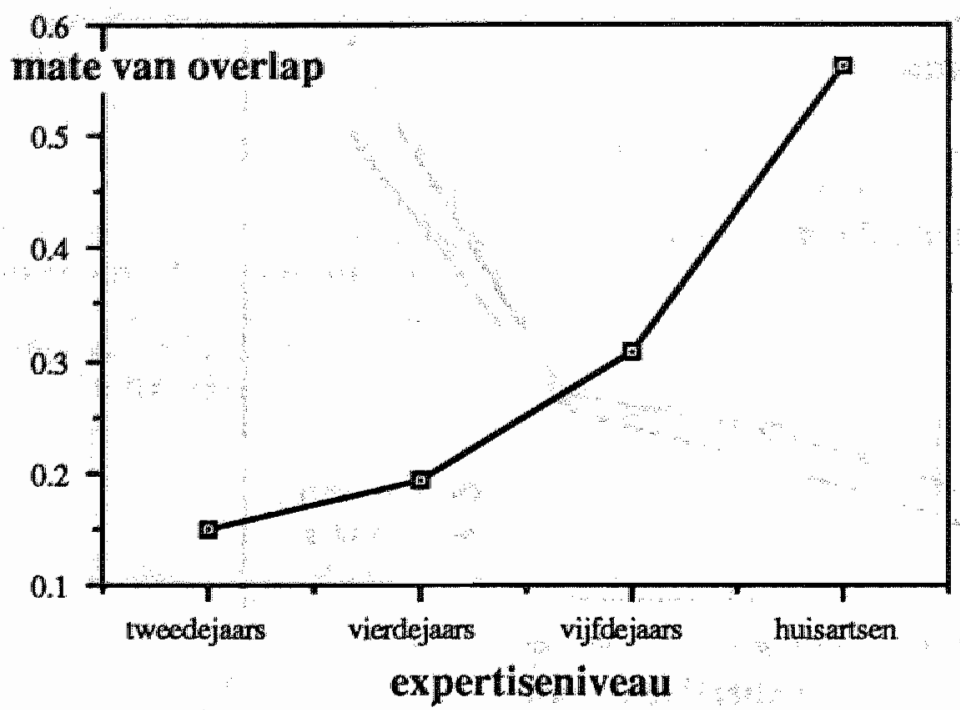

Figuur 4.8 Mate van overlap tussen de pathofysiologische proposities, ontleend aan de hardop-denk protocollen en de pathofysiologische netwerken, gebaseerd op de post hoc pathofysiologische verklaringen van de casus (uitgedrukt in de proportie concepten in het netwerk die identiek zijn aan enig concept dat in de hardop-denk proposities van de proefpersoon voorkomt).

\section{Discussie}

De resultaten van Experiment 4 laten zien dat ook bij gebruik van een on-line methode gevonden wordt dat experts in de geneeskunde minder gebruik maken van kennis van de medische basisvakken dan personen van een intermediair expertiseniveau, zoals dat ook eerder in Experiment 2 en 3 werd geconstateerd. In deze paragraaf laten we de hypothesen nog eens de revue passeren, die werden opgesteld om dit verschijnsel te verklaren.

Rudimentaire kennis- De eerste hypothese, die werd geformuleerd om dit verschijnsel te verklaren, luidde dat experts geen kennis van de medische basisvakken toepassen omdat die rudimentair is geworden. Deze hypothese werd verworpen, omdat analyse van de post hoc pathofy siologische verklaringen aantoonde dat de verklaringen van de experts uitgebreider waren dan de verklaringen van de personen met een lager expertiseniveau.

Dit beeld wordt nog versterkt wanneer we de inhoud van de pathofysiologische verklaringen bij dit resultaat betrekken. Een kwalitatieve analyse van die verklaringen laat zien, dat bij de novicen slechts één van de zes netwerken iets bevat dat als de toepassing van pathofysiologische kennis kan worden omschreven. Deze proefpersoon spreekt over een vergiftigingsproces. $\mathrm{Bij}$ de vierdejaars studenten geldt dit bij twee van de vier verklaringen. Dit loopt op tot drie van de vijf vijfdejaars en vier van de vijf experts. In de pathofysiologische netwerken van de artsen komen we concepten tegen als weefselversterf, pancreasenzymen, atypische ontste- 
kingsreaktie, verlittekening van het weefsel, verandering van de struktuur van de afvoergangen en opslag van stoffen uit het metabolisme. Eén arts (\#a-16) is een uitzondering. Diens pathofysiologisch netwerk is erg grofmazig en bevat een aantal Enabling Conditions (alcohol en Aspirinegebruik) en Faults, met mogelijk bijkomende complicaties. Zowel de toename in de omvang van de pathofysiologische netwerken als de inhoud ervan wijzen er dus op dat de kennis van de medische basisvakken, die de proefpersonen op deze casus kunnen toepassen, toeneemt met een stijgend expertiseniveau.

Inerte kennis- De tweede hypothese die werd gesteld, luidde dat de kennis van de medische basisvakken van experts inert is geworden, waardoor experts minder dan intermediates dit type kennis toepassen bij het oplossen van medische problemen. Het feit dat er een toenemende overlap gevonden wordt tussen toepasbare kennis van de medische basisvakken en de kennis van ziektebeelden, die feitelijk toegepast wordt bij het diagnosticeren van een casus, wijst erop dat er geen sprake is van inert geworden anatomische en (patho)fysiologische kennis bij de experts. Deze hypothese staat in nauw verband met de volgende hypothese.

Gecompileerde kennis- Dezelfde bevinding, op grond waarvan werd geconcludeerd dat er geen sprake is van inerte kennis bij experts, leídde uiteindelijk tot aanname van de derde hypothese. Deze hypothese luidde dat de kennis van de medische basisvakken bij experts gecompileerd is in de kennis omtrent ziekten en ziektebeelden die toegepast wordt bij het diagnosticeren van een medische casus, zodat de toepassing van deze kennis geen sporen nalaat in het hardop-denk protocol.

Bij deze hypothese en deze conclusie moeten we toch wat langer stilstaan. Deze conclusie werd getrokken uit het resultaat, dat er sprake is van een toenemende overlap tussen kennis van de medische basisvakken en kennis van ziektebeelden, die toegepast wordt bij het diagnosticeren van een casus. Deze bevinding leidt echter niet noodzakelijkerwijs tot de conclusie dat er dus sprake is van compilatie en van verkorting van de zoekpaden in het pathofysiologische kennisbestand zoals onze theorie voorspelt. Er is ook een andere verklaring van dit resultaat mogelijk, een verklaring die wel uitgaat van twee verschillende kennislagen, maar waarbij het leer- en ontwikkelingsproces op een andere wijze plaatsvindt.

De tot nu toe verwoorde theorie over expertisevorming stelt dat een ziektescript ontstaat op basis van compilatie van anatomische en (patho)fysiologische kennis tot een cluster van symptomen van een ziektebeeld. Daarna zouden deze clusters verrijkt worden met kennis omtrent relevante patiëntenkenmerken en zou de kennis omtrent symptomen van een aandoening flexibeler worden. Op deze wijze zouden de ziektescripts ontstaan uit de kennis van de medische basisvakken. In plaats daarvan is een alternatieve theorie mogelijk die ervanuit gaat dat beide typen kennis tegelijkertijd worden gevormd, maar in het begin weinig of geen raakpunten hebben. Met een toenemend expertiseniveau zouden beide kennissoorten steeds meer gemeenschappelijke concepten krijgen. Ook in dit geval zou een toename van het expertiseniveau leiden tot een toenemende overiap in 
de concepten die daadwerkelijk worden toegepast blijkens de hardop-denk protocollen en de concepten in de pathofysiologische verklaringen. In dit geval is er echter geen sprake van compilatie maar van uitbouw ('accretion') van de kennis.

Om te kunnen onderscheiden tussen uitbouw en compilatie moet dus niet alleen de mate van overlap in de concepten worden bepaald. Twee kennisbestanden die 'naar elkaar toegroeien' hebben - naar we veronderstellen - niet alleen een toenemend aantal gemeenschappelijke concepten, maar ook steeds meer gemeenschappelijke proposities. Een kennisbestand dat ontstaat op basis van compilatie van een ander kennisbestand zal daarentegen geen proposities met dat andere kennisbestand gemeenschappelijk hebben. In plaats daarvan zullen de proposities in de gecompileerde kennislaag samenvoegingen zijn van meerdere proposities in de geëlaboreerde kennislaag. Compilatie leidt immers tot verkorting van de zoekpaden.

Om deze alternatieve verklaring te onderzoeken werden de proposities ontleend aan de hardop-denk protocollen, geprojekteerd op de pathofysiologische netwerken. Vervolgens werd bepaald of de hardop-denk propositie gelijk was aan de netwerkpropositie (bestaande uit twee concepten die met elkaar verbonden zijn), waarop deze was geprojekteerd. Deze noemen we 'identieke proposities'. Er is sprake van een 'verkorting' wanneer één hardop-denk propositie een samenvoeging is van meerdere netwerkproposities. Dit type proposities beschrijft verkortingen van zoekpaden door het pathofysiologisch netwerk. Voorbeelden hiervan treft $u$ aan in Figuur 4.9, waarin alcoholgebruik $\rightarrow>$ pancreatitis' en 'pancreatitis $\rightarrow>$ serumamylase verhoogd" verkorte zoekpaden in het pathofysiologische netwerk beschrijven.

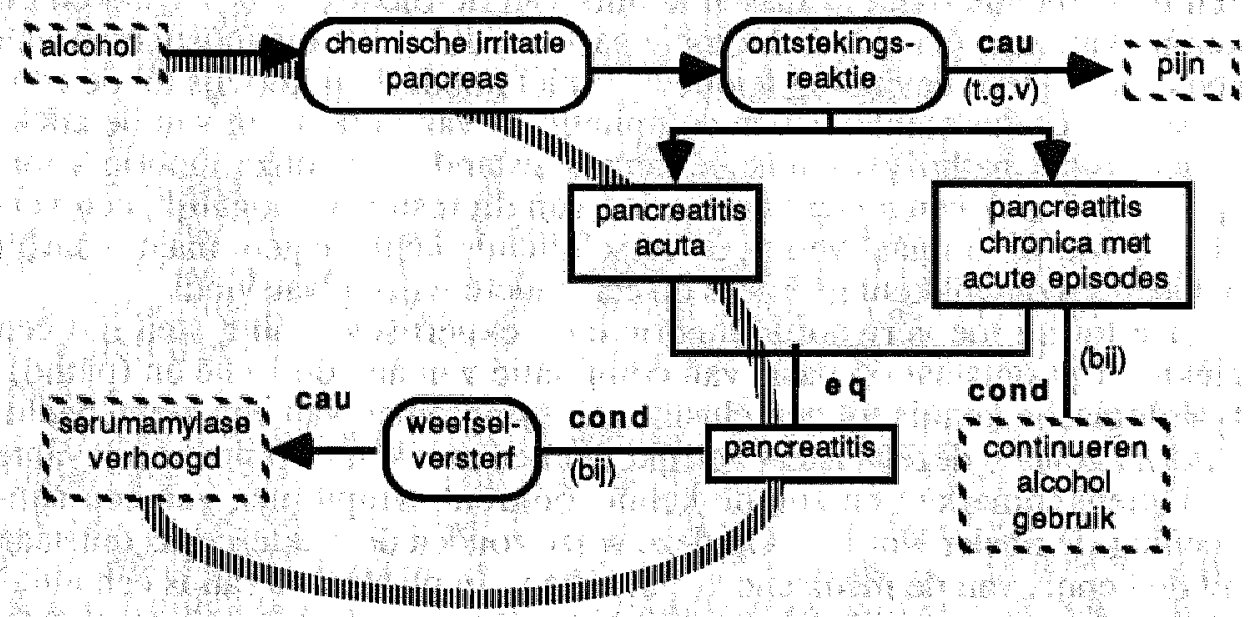

Figuur 4.9 Deel van het pathofysiologisch netwerk van Expert \#a-14 met daarop gesuperponeerd de verkortingen, die ontstaan door matching met diens hardop-denk proposities. 
Van 'alternatieve proposities' is sprake wanneer de hardop-denk propositie op andere wijze twee netwerk-concepten met elkaar verbindt. Dit zou bijvoorbeeld het geval zijn wanneer 'weefselversterf' en 'pijn' met elkaar worden verbonden. Als een toenemende mate van expertise gepaard gaat met een toenemende mate van integratie van kennis van de medische basisvakken in ziektescripts dan zal het aantal identieke proposities toenemen. Als daarentegen een toenemende mate van expertise gepaard gaat met een toenemende mate van compilatie van kennis van de medische basisvakken in ziektescripts dan moeten we verwachten dat het aantal verkortingen zal toenemen.

De analyse van het aantal identieke verbindingen in de hardop-denk proposities en in de causale netwerken laat geen significante verschillen zien tussen de vier expertiseniveaus $(F(3,15)=1.625, p=.225)$. Hetzelfde geldt voor het aantal alternatieve proposities $(\mathrm{F}(3,15)=1.7105, \mathrm{p}=.2076)$. Daarentegen blijkt het aantal verkortingen wel significant samen te hangen met het expertiseniveau van de proefpersonen $(F(3,15)=9.088$, $p=$ $.0011)$. De lineaire component in deze relatie is significant $(F(1,15)=$ $21.8127, \mathrm{p}=.0003$, zonder significante deviaties: $\mathrm{p}=.0978$ ). De resultaten van deze analyses zijn weergegeven in Figuur 4.10.

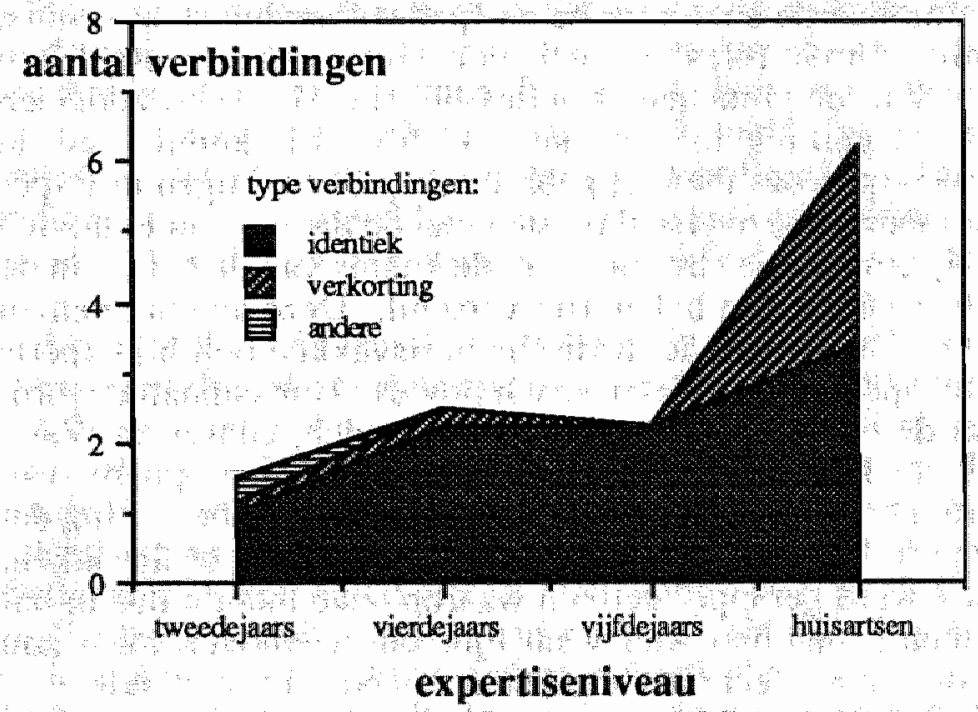

Figuur 4.10 Drie typen verbindingen tussen de concepten in de hardop-denk proposities die zijn gevonden bij de vergelijking tussen de pathofysiologische netwerken van de proefpersonen en de hardop-denk protocollen.

Deze resultaten laten zien dat de experts bij het diagnosticeren van de casus systematisch gebruik maken van verkortingen in hun kennis van de medische basisvakken. Bij de minder ervaren proefpersonen is dit nauwelijks het geval. Dit wijst erop dat er bij de experts sprake is van compilatie van kennis van de medische basisvakken. Het aantal alternatieve proposities is te verwaarlozen en bij de hogere expertiseniveau geheel afwezig. Verder wijzen de resultaten erop dat het aandeel van de identieke 
proposities in alle gevallen het grootst is. Deze maat blijkt niet significant samen te hangen met het expertiseniveau. Hieruit kan geconcludeerd worden dat er geen sprake is van een toenemende integratie van beide soorten kennis. Op alle expertiseniveaus schijnt de kennis, die wordt gebruikt bij het diagnosticeren van de casus gedeeltelijk samen te vallen met de pathofysiologische kennis, die op de casus van toepassing is. Dit zou erop kunnen wijzen dat de kennis van de experts nog niet volledig is gecompileerd.

Tezamen spreken deze resultaten dus in het voordeel van de theorie dat experts bij het oplossen van een probleem gebruik maken van gecompileerde kennis van de medische basisvakken; ze pleiten tegen de theorie dat er sprake is van een toenemende integratie van ziektescriptkennis en anatomische en (patho)fysiologische kennis.

\section{ALGEMENE DISCUSSIE}

Experiment 3 en 4 waren bedoeld om de hypothese te onderzoeken dat experts in de geneeskunde bij het oplossen van problemen gebruik maken van clusters gecompileerde anatomische en (patho)fysiologische kennis, verrijkt met kennis omtrent relevante patiëntenkenmerken en, vergeleken met minder ervarenen, een grote mate van flexibiliteit. Medische studenten daarentegen zouden gebruik maken van geëlaboreerde kennis van de medische basisvakken. Deze theorie, gebaseerd op bevindingen in Experiment 1 en 2, vertoont grote overeenkomsten met de theorie van Feltovich en Barrows (1984) omtrent de struktuur van de kennis yan de expert in de geneeskunde. Er is echter én belangrijk verschil. Deze auteurs nemen namelijk aan dat de kennis van de medische basisvakken ook bij experts een belangrijke roll speelt in het diagnostisch proces. Hun aanname wordt ondersteund door de bevinding van Lesgold, Feltovich, Glaser en Wang (1981) dat radiologen bij het diagnosticeren van een Röntgen-opname van de thorax uitgebreid gebruik maken van dit type kennis. De bevinding dat experts minder gebruik maken van kennis van de medische basisvakken, die in Hoofdstuk 2 werd gerapporteerd en waarop onze theorie dus in belangrijke mate steunt, staat hier weliswaar lijnrecht tegenover, maar zou kunnen berusten op een artefact van de gehanteerde post hoc methode.

Ziektescripts- Experiment 3 liet zien dat de ziektescripts, die de expert in dat onderzoek gebruikte, kant-en-klaar aanwezig zijn en slechts geinstantieerd behoeven te worden. Ze worden geaktiveerd door een conglomeraat van gegevens omtrent de achtergronden van de patiënt, diens medische en psychiatrische voorgeschiedenis en de klacht die hij presenteert. Deze scripts zijn veel rijker en zijn meer flexibel dan de scripts van de minder ervaren proefpersonen, die bovendien niet goed schijnen te passen bij de gegevens van de casus. Bestaande scripts moeten dus gemodificeerd worden. Als dat niet lukt, zoals bij de vierdejaars student het geval lijkt te zijn, moet een interne representatie van de casus worden opgebouwd met behulp van kennis van de medische basisvakken. Het heeft er 
echter alle schijn van dat ook deze proefpersoon, ondanks de afwezigheid van een toepasbaar ziektescript, poogt een inteme representatie op te bouwen die toch alle componenten van het ziektescript bevat (Enabling Conditions die het verkrijgen van een aandoening in de hand werken, de verstoring zelf, en de gevolgen ervan, de symptomen). Tot zo ver lijken de resultaten onze theorie volledig te ondersteunen. Er is een duidelijk verschil tussen de vierdejaars student en de Expert: de ene lijkt geellaboreerde kennis toe te passen, de andere gecompileerde. Verder lijkt de kennis van de Expert, vergeleken met de vijfdejaars student verrijkt en meer flexibel te zijn.

Kennis van de medische basisvakken- Onze theorie gaat er verder vanuit dat de kennis van de medische basisvakken bij experts gecompileerd is in de ziektescripts die zij gebruiken om een casus op te lossen. Het geringe gebruik van dit type kennis door de experts vergeleken met de jongere intermediates, zowel in Experiment 3 als in Experiment 4, ondersteunt deze hypothese. De mogelijkheid moest echter niet worden uitgesloten dat de kennis van de experts inert of rudimentair is geworden. De analyses geven duidelijk aan dat dit laatste zeker niet het geval is. Toch vormen ze ook geen complete ondersteuning voor de theorie dat ziektescripts ontstaan door compilatie van de kennis van de medische basisvakken. Wel is het zo dat de ziektescripts van de experts gecompileerde kennis van de medische basisvakken lijken te bevatten, in tegenstelling tot de ziektescripts van de minder ervaren proefpersonen. Dit wordt duidelijk gesuggereerd door de bevinding dat alleen de hardop-denk protocollen van de artsen proposities bevatten, die beschouwd kunnen worden als verkortingen van de zoekpaden in de kennis van de medische basisvakken.

De ontwikkeling van deze twee aspekten van de medische kennis, aan de ene kant de ziektescripts en aan de andere kant de kennis van de anatomie, fysiologie, pathologie, microbiologie, immunologie etcetera, grijpen dus in elkaar. Maar er kan niet gezegd worden dat compilatie van kennis van de medische basisvakken de ziektescripts oplevert, noch dat eerst de ziektescripts worden opgebouwd en dat deze ziektescripts gaande weg steeds beter onderbouwd worden met pathofysiologische kennis.

Het leerproces lijkt eerder aan te vangen op beide lagen tegelijk. Zowel novicen als experts hebben pathofysiologische kennis en meer of minder algemene ziektescripts (die kunnen variëren in uitgebreidheid en specificiteit) tot hun beschikking. De opbouw van de ziektescripts lijkt zich daarbij in eerste instantie vooral op de Consequences te richten. Het volle gebruik van de Enabling Conditions lijkt voorbehouden te zijn aan de experts. Deze bevinding is in overeenstemming met de resultaten van Schmidt, Hobus, Patel en Boshuizen (1987) en Hobus, Hofstra, Boshuizen en Schmidt (1988), die het gebruik van Enabling Conditions onderzochten bij basisartsen en ervaren huisartsen. Deze onderzoekers vonden dat de diagnostiek van de ervaren artsen beïnvloed wordt door de beschikbaarheid van gegevens over Enabling Conditions, terwijl dit bij de basisartsen niet het geval was. 
Ook de pathofysiologische kennislaag schijnt een continue ontwikkeling te ondergaan. In ieder geval rond het onderwerp pancreatitis neemt de pathofysiologische kennis gestaag toe met een stijgend expertiseniveau. Daarbij blijkt tevens sprake van een toenemende integratie van kennisdelen. Kennis over de 'lever' raakt verbonden met kennis omtrent de 'pancreas'. Compilatie van de kennis van de medische basisvakken en integratie in de ziektescript-laag lijkt echter pas in een heel laat stadium van het ontwikkelingsproces plaats te vinden. 


\section{HOOFDSTUK 5}

\section{EEN ONTWIKKELINGSTHEORIE \\ VAN \\ MEDISCHE EXPERTISE}

\section{INLEIDING}

In de voorgaande hoofdstukken is gepoogd een antwoord te vinden op de volgende vragen: a) wat is medische expertise, b) waardoor wordt de kennis van de expert in de geneeskunde, in vergelijking met minder ervaren personen, gekenmerkt en c) hoe verloopt het ontwikkelingsproces van beginner tot expert? In onze visie op expertise speelt de kennis en de ontwikkeling daarvan een belangrijke rol. De theorievorming heeft zich daarop dan ook geconcentreerd.

De ontwikkeling van beginner tot expert in de geneeskunde speelt zich af in een omgeving met bepaalde kenmerken, namelijk in de medische opleiding en daarna in de praktijk. Sinds het pleidooi van Boerhaave voor een wetenschappelijke onderbouwing van de geneeskunde, bestaat een belangrijk deel van het onderwijs in de geneeskunde uit vakken als anatomie en pathologie (Lindeboom, 1972). In de klassieke curricula zijn deze vakken meestal aan het begin van de studie geplaatst en worden zij later gevolgd door de meer toegepaste medische vakken als interne geneeskunde, cardiologie, neurologie, gynaecologie en huisartsgeneeskunde. Ook in de innovatieve curricula valt een dergelijke opbouw te bespeuren, getuige het onderwijsprogramma van de Faculteit der Genees- 
kunde aan de Rijksuniversiteit Limburg. In de eerste jaren ligt het accent op de bouw, het funktioneren en het dysfunktioneren van het menselijk lichaam. In de latere jaren (het derde en vierde studiejaar) wordt daarentegen de klacht waarmee een patiënt een arts raadpleegt als organiserend principe gebruikt (Onderwijscommissie Faculteit der Geneeskunde, 1987) om de meer toegepaste medische vakken te bestuderen. De laatste twee jaar zijn gewijd aan het leren toepassen van de kennis in de praktijk tijdens de co-schappen. De studies die in dit proefschrift zijn gepresenteerd, beschrijven aspekten van het ontwikkelingsproces, dat plaatsvindt bij studenten die een dergelijk curriculum doorlopen, en het vervolg van die ontwikkeling, zoals die zich ook daarna in de praktijk voltrekt.

De theorie die in dit proefschrift is ontwikkeld en getoetst, is op een aantal pijlers gebaseerd: op een informele analyse van de kenmerken van de problemen die zich in het medisch domein voordoen; op een informele analyse van de kenmerken van de situatie waarin medische studenten hun kennis verwerven (het medisch curriculum); op theorieën rond de ontwikkeling van kennis en cognitieve vaardigheden (Anderson, 1983, 1987; Rumelhart en Norman, 1978); op de theorie van Feltovich en Barrows (1984) omtrent de struktuur van de kennis van experts in de geneeskunde; en op een viertal empirische onderzoekingen bij proefpersonen van verschillend expertiseniveau (studenten van verschillende jaargroepen en ervaren artsen) naar kenmerken van hun kennis en de effekten daarvan op de wijze waarop zij een medisch diagnostisch probleem representeren en oplossen.

In de volgende paragrafen zullen eerst deze theorie en de empirische ondersteuning ervoor worden samengevat. Daarna volgt een kritische bespreking van de tekortkomingen van de theorie en tenslotte volgt een paragraaf waarin de implicaties van de bevindingen in dit proefschrift voor het medisch onderwijs worden uiteengezet.

\section{STAND VAN ZAKEN: THEORIE EN EMPIRISCHE ONDERSTEU- NING}

Wanneer we de ontwikkeling van iemands kennis in chronologische volgorde beschrijven, dan is duidelijk dat er in het eerste stadium, gedurende de preklinische jaren, een enorme accumulatie van kennis plaatsvindt. Studenten maken zich eerst allerlei vakken eigen, betreffende de bouw, het funktioneren en dysfunktioneren van het menselijk organisme en de mechanismen die het ten dienste staan om op verstoringen te reageren. Dit zijn vakken als de anatomie, de fysiologie, de pathologie, de immunologie en de microbiologie. Verder leert de student meer toegepaste vakken waarin de ziektebeelden worden bestudeerd, die het gevolg zijn van allerlei verstoringen. Voorbeelden hiervan zijn de neurologie, de kindergeneeskunde, de interne geneeskunde en de gynaecologie.

Al deze verschillende vakken moet de student zich in de eerste vier jaar van de opleiding eigen zien te maken. Minstens even belangrijk is dat 
deze vakken met elkaar worden geïntegreerd en dat relaties over vakken heen worden gelegd, zodat een samenhangend kennisbestand wordt gevormd. Bovendien moet hij of zij ervoor zorgdragen dat dit kennisbestand geen onjuistheden bevat en betrouwbaar is. Het geellaboreerde kennisbestand dat op deze wijze wordt opgebouwd, vormt de basis waarop in de volgende fase wordt voortgebouwd.

De volgende fase neemt een aanvang wanneer de student tijdens de co-schappen zijn of haar kennis in de (poli)kliniek of bij de huisarts in de praktijk moet gaan toepassen. De ontwikkeling die in deze fase plaatsvindt, wordt gekenmerkt door een aantal processen, die ook na beëindiging van de opleiding nog lange tijd zullen voortgaan:

a) De kennis van de medische basisvakken die in de vorige fase verworven is, wordt gecompileerd. Door compilatie treden veranderingen in de geëlaboreerde kennis op, waardoor concepten die eerst 'aan elkaar moesten worden geredeneerd' nu direkt met elkaar verbonden raken (Anderson, 1983, 1987; Rumelhart en Norman, 1978). Op deze wijze worden zoekpaden verkort en wordt de toepassing van de kennis geautomatiseerd. Op deze wijze zouden in de kennis clusters van symptomen van ziektebeelden met de bijbehorende diagnose ontstaan.

b) Deze clusters van symptomen van ziektebeelden worden vervolgens verrijkt met kennis rond relevante kenmerken van patiënten die betrekking hebben op het verkrijgen van die ziekte. Kennis van deze faktoren bij patiënten verbetert de toepasbaarheid van de kennis. De kennis wordt in zekere zin "geconditionaliseerd' (Glaser, 1986).

c) De flexibiliteit van de kennis van symptomen van ziekten wordt daarnaast vergroot onder invloed van de natuurlijke variabiliteit van ziektebeelden die men in de praktijk tegenkomt.

Deze ontwikkelingen leiden uiteindelijk tot een kennisbestand dat is opgebouwd uit 'ziektescripts' (Feltovich en Barrows, 1984). Ziektescripts bevatten drie verschillende componenten. Ten eerste is er de kennis omtrent de faktoren, die het verkrijgen van een aandoening in de hand werken. Deze faktoren worden de 'Enabling Conditions' genoemd. Verder is er de gecompileerde kennis omtrent de verstoring die in het organisme heeft plaatsgevonden, de 'Fault'. En tenslotte is er de kennis omtrent de verschijnselen en symptomen van een aandoening, die de 'Consequences' worden genoemd. Een ziektescript beschrijft als het ware hoe patiënten met bepaalde kenmerken een bepaalde ziekte kunnen krijgen, wat daarvan de verschijnselen zullen zijn en welke variaties daarin mogelijk zijn.

Door deze strukturele veranderingen in de kennis vinden er ook veranderingen plaats in de manier waarop iemand diagnostische problemen met behulp van de beschikbare kennis kan oplossen. Studenten in de preklinische fase, die dus gebruik maken van een geëlaboreerd kennisbestand, moeten bij het diagnosticeren van de aandoening waaraan een patiënt lijdt, hun kennis aktief en bewust redenerend toepassen. Kennis over een aandoening en over de symptomen van die aandoening zijn ech- 
ter nog niet sterk met elkaar verbonden, en vaak zullen ze worden gemedieerd door kennis over pathofysiologische processen die aanleiding geven tot de bedoelde symptomen.

De construktie van de interne representatie, waarmee de verschijnselen van de patiënt in een verklarend kader worden geplaatst, zal in belangrijke mate een bottom up proces zijn. Nieuwe informatie over de verschijnselen waaraan de patiënt lijdt, kan daarbij aanleiding geven tot aktivatie van weer een ander concept uit het kennisbestand. En deze nieuw geaktiveerde kennis moet al redenerend gekoppeld worden aan al eerder geaktiveerde kennis, wil een samenhangende representatie ontstaan. De interne representatie van het voorgelegde probleem komt dus moeizaam tot stand.

Experts daarentegen hebben de beschikking over een grote verzameling van rijke, flexibele ziektescripts die snel, met gebruikmaking van de relevante patiëntkenmerken, kunnen worden geaktiveerd. Daarna worden de geaktiveerde scripts geverifieerd aan de verdere kenmerken van de patiẻnt en de verschijnselen die deze vertoont. Ieder script bevat een wisselend aantal van relevante kenmerken en symptomen, de attributen, en de range van bevindingen die op ieder attribuut toelaatbaar zijn. Aktivatie van een script leidt er automatisch toe dat deze attributen beschikbaar komen als een soort van checklist van eisen waaraan de patiënt verder moet voldoen, wil de diagnose toepasselijk zijn. Invullen van deze lijst van attributen wordt 'script-instantiatie' genoemd. De probleemrepresentatie kan op deze wijze snel tot stand komen en vindt voornamelijk via top down verwerking plaats.

In een viertal experimenten werd empirische ondersteuning voor deze theorie verzameld. Deze resultaten zullen we hier bespreken, aangevuld met de resultaten van een aantal andere studies. Dit zal gebeuren aan de hand van drie vragen:

a) In welke mate wordt de hypothese ondersteund dat de kennis van experts in de geneeskunde gerepresenteerd is in de vorm van ziektescripts?

b) In welke mate wordt de hypothese ondersteund dat de kennis van de medische basisvakken bij experts is gecompileerd?

c) In welke mate wordt de hypothese ondersteund dat de kennis van de medische basisvakken bij experts tot ziektescripts is gecompileerd?

Ziektescripts-In twee experimenten wordt ondersteuning gevonden voor de hypothese dat ziektescripts gebruikt worden bij het representeren van een casus en voor de theorie dat de medische kennis van experts in deze vorm gerepresenteerd is. De eerste belangrijke aanwijzing vinden we in Experiment 1. In dit experiment bestudeerden de proefpersonen een tweetal casus, diagnosticeerden die en reproduceerden vervolgens de casus. Uit de resultaten bleek dat naarmate het expertiseniveau verder toenam de proefpersonen meer de neiging vertoonden om de casusinformatie in een bepaalde, vaste volgorde te reproduceren. Deze volgorde van reproduktie is indicatief voor de wijze waarop informatie is opgeslagen en 
voor de kennisstrukturen die daarbij aktief waren. De meer ervaren proefpersonen beschreven achtereenvolgens de personalia, de achtergrondgegevens van de patiënt en de medische voorgeschiedenis (tezamen vormen zij de Enabling Conditions) en daarna pas de klacht, anamnese-, onderzoek- en laboratoriumgegevens (de Consequences). Bij minder ervaren proefpersonen wordt deze volgorde minder vaak gevonden. $\mathrm{Zij}$ gaven bijvoorbeeld vaker blijk van een recency effect door de laboratoriumgegevens als eerste te vermelden.

Deze volgorde werd echter ook gedeeltelijk gehanteerd bij de presentatie van de casus, zodat de toenemende overeenkomst tussen outputvolgorde en ziektescript ook beschreven kan worden als een toenemende overeenkomst tussen input en output. Een experiment van Coughlin en Patel (1986), waarin naast een normale presentatievolgorde ook een gerandomiseerde volgorde werd gebruikt, laat echter zien dat er ook in dit geval sprake is van een toenemende overeenkomst in de recall met het ziektescriptformat, terwijl bovendien de recall van de studenten sterker te lijden had van dit doorbreken van de patiëntpresentatieconventies.

Een verder ondersteuning van de theorie dat de kennis van experts in de geneeskunde is gerepresenteerd in de vorm van ziektescripts, wordt gevonden in Experiment 3. In dit experiment bleek dat de Expert in tegenstelling tot de minder ervaren proefpersonen hypothesen omtrent de aandoening van de patiënt genereert op grond van de klacht en een aantal kenmerken omtrent de personalia van de patiënt en diens medische en psychiatrische voorgeschiedenis. De andere, minder ervaren proefpersonen aktiveren hun hypothesen in hoofdzaak op grond van de symptomen die de patiënt vertoont. Deze verschuiving is een aanwijzing dat een rijk, geconditionaliseerd kennisbestand is ontstaan, hetgeen in overeenstemming is met de wijze waarop ziektescripts zich volgens de onderzochte theorie zouden ontwikkelen.

Kennis van de medische basisvakken-De theorie voorspelt dat de kennis van de medische basisvakken in de eerste fase van de ontwikkeling tot expert wordt uitgebouwd en daarna wordt gecompileerd. Dit aspekt van de theorie is met name in Experiment 1 en 2 onderzocht. In Experiment 1 werd dit gedaan door, met behulp van een recallmethode, de kenmerken van de interne representatie van een medisch diagnostisch probleem te onderzoeken, waarin dit aspekt van de kennis tot uitdrukking zou moeten komen. In dit experiment bleek dat de snelheid, waarmee men de casus representeerde, toenam met een toenemend expertiseniveau. Verder bleek dat de hoeveelheid recall met een toenemend expertiseniveau eerst steeg, maar daarna weer afnam. Deze resultaten zijn in overeenstemming met de theorie dat jongerejaars studenten bij het representeren van de casus geëlaboreerde kennis toepassen, waardoor zij zich veel van de casus kunnen herinneren, maar ook veel tijd nodig hebben. Daartegenover staan de ouderejaars studenten en artsen, die gecompileerde kennis zouden gebruiken, die in grote eenheden geaktiveerd kan worden. Hierdoor behoeven ze niet aktief te redeneren, hebben ze dus minder tijd 
nodig, maar kunnen ze zich achteraf ook minder van de casusgegevens herinneren.

In Experiment 2 werd deze hypothese getoetst door; bij personen van verschillend expertiseniveau, de interne representatie van een casus na verschillende bestuderingstijden te onderzoeken. Als de kennis, die experts toepassen bij het oplossen van een casus, inderdaad gecompileerd is en dus in zijn geheel zonder aktief redeneren geaktiveerd wordt, dan mag hun interne representatie niet te lijden hebben onder verkorting van de bestuderingstijd. De interne representatie van personen van een lager expertiseniveau, die volgens de theorie geellaboreerde kennis zouden toepassen, zal wel beinvloed worden door verkorting van de beschikbare tijd. Ook de aktivering van relevante delen van de kennis van de medische basisvakken zou bij studenten wel en bij experts niet beinvloed moeten worden door verkorting van de bestuderingstijd. Dit laatste werd onderzocht door te vragen het pathofysiologisch proces te beschrijven dat aan de voorgelegde casus ten grondslag ligt.

De resultaten van dit onderzoek lieten zien dat de recall van de studenten in sterke mate beïnvloed werd door de beperking van de bestuderingstijd. Bovendien bleken zij onder deze omstandigheden veel minder relevante kennis te kunnen aktiveren dan wanneer ze ruim de tijd kregen. De experts daarentegen bleken op generlei wijze beinvloed te worden door deze restricties: ze reproduceerden even veel yan de casus, ze aktiveerden even veel kennis en hun diagnose leed er niet onder. Deze bevindingen ondersteunen in sterke mate de theorie dat er gedurende de ontwikkeling tot expert in de geneeskunde twee processen een rol spelen: eerst is er duidelijk sprake van kennisaccumulatie, daarna vindt compilatie van de kennis plaats.

Ontstaan van ziektescripts- Het laatste element van de theorie waarvoor hier de empirische onderbouwing zal worden gepresenteerd, betreft de notie dat ziektescripts ontstaan uit gecompileerde kennis van de medische basisvakken. Deze vraag is met name aan de orde geweest in Experiment 4 waarin werd onderzocht of er gedurende de ontwikkeling tot expert sprake is van compilatie van (patho)fysiologische kennis, dan wel van inert worden van die kennis, of zelfs van rudimentair worden daarvan.

In Experiment 4 kregen de proefpersonen een casus voorgelegd. Deze casus werd hardop-denkend bestudeerd en gediagnosticeerd. En tenslotte beschreven de proefpersonen het pathofysiologische proces dat volgens hen aan de verschijnselen van de patiënt ten grondslag zou liggen. De vraag of er sprake is van een toenemende mate van compilatie van de kennis van de medische basisvakken werd onderzocht door de kennis die daadwerkelijk werd toegepast tijdens het hardop-denken te vergelijken met de kennis die daarna werd geproduceerd ter verklaring van de verschijnselen van de patiënt.

Uit de resultaten van dit onderzoek bleek dat alleen de experts systematisch gebruik maken van verkorte zoekpaden door hun kennis van de 
medische basisvakken wanneer zij een casus diagnosticeren. De verwachte graduele toename werd dus niet gevonden. Dit wijst erop dat er alleen bij de experts sprake is van compilatie van kennis van de medische basisvakken. Verder bleek dat bij alle expertiseniveaus de pathofysiologische verklaringen dezelfde kenniselementen bevatten als de hardop-denk protocollen. Hieruit kan geconcludeerd worden dat er op alle expertiseniveaus sprake is van enige integratie van de kennis die wordt toegepast bij het diagnosticeren van de casus en de pathofysiologische kennis die op de casus van toepassing is zonder dat die integratie veroorzaakt wordt door compilatie van de kennis.

Ziektescriptkennis ontstaat dus niet uitsluitend uit gecompileerde kennis van de medische basisvakken. Het leerproces lijkt eerder aan te vangen op beide lagen tegelijk. Zowel beginners als experts hebben pathofysiologische kennis en meer of minder algemene ziektescripts (die kunnen variëren in uitgebreidheid en specificiteit) tot hun beschikking. De opbouw van de ziektescripts lijkt zich daarbij in eerste instantie vooral op de Consequences te richten, terwijl het volle gebruik van de Enabling Conditions voorbehouden lijkt te zijn aan de Experts. Deze ontwikkeling van de ziektescriptkennis zet zich voort tot in het expertstadium, maar ook de ontwikkeling van de kennis van de medische basisvakken gaat door, getuige de omvang van de pathofysiologische verklaringen die lineair toeneemt met het expertiseniveau van de proefpersonen. Bij de experts is deze kennis tenslotte gecompileerd in de ziektescriptkennis, maar is blijkens de resultaten van Experiment 4 ook in geëlaboreerde vorm beschikbaar.

Nogmaals de rol van kennis van de medische basisvakken en ziektescripts in het diagnostisch proces-Dat de kennis van de medische basisvakken bij experts ook in geëlaboreerde vorm beschikbaar blijft, kan misschien verklaren waarom er tegenstrijdige resultaten gevonden werden in verschillende onderzoekingen naar het gebruik van medische basiskennis bij het oplossen van problemen.

Lesgold, Feltovich, Glaser en Wang (1981) vonden dat experts in de radiologie meer anatomische en pathologische kennis toepasten bij het diagnosticeren van Röntgen-opnamen van de thorax dan minder ervaren personen. Hun kennis was uitgebreider, gedetailleerder, relevanter en meer doelgericht dan de kennis die door gevorderden en beginners in dat vakgebied werd toegepast.

De resultaten van Patel, Arocha en Groen (1986) beschrijven een onderzoek waarin zij een casus voorlegden aan echte experts op een bepaald vakgebied en aan artsen die ook over de relevante kennis beschikten, maar deze niet dagelijks in de medische praktijk toepasten. Hun resultaten laten zien dat alleen de onervaren artsen gebruik maakten van hun kennis van de medische basisvakken bij het diagnosticeren van de casus. De ervaren artsen leken gebruik te maken van gecompileerde kennis waarmee de diagnose snel en zonder redeneren gesteld kan worden. 
Een vergelijkbaar verschijnsel werd gesignaleerd door Swanson'. In voorstudies voor een onderzoek naar de kennisstruktuur van artsen, assistenten en studenten op het gebied van de kindercardiologie (Feltovich, Johnson, Moller en Swanson, 1984) bemerkte hij dat de mate waarin experts causale redeneringen toepassen op grond van medische basiskennis, samenhangt met de typiciteit van de voorgelegde casus. Hoe meer gegevens in de casus afwijken van wat er normaal bij een dergelijk ziektebeeld wordt gevonden, hoe meer men zijn toevlucht neemt tot de kennis van de basisvakken.

Dit zou er dus op wijzen dat experts bij het oplossen van een medisch probleem in eerste instantie gebruik maken van ziektescriptkennis en pas als die niet voorhanden is, terugvallen op de kennis van de anatomie, pathologie, pathofysiologie, etcetera. Schmidt en Norman (1989) zeggen in dit verband dat het toepassen van dit type kennis kenmerkend is voor de expert die 'er niet goed uitkomt'.

In het onderzoek van medische expertise zoals dat plaatsvindt in de context van het onderzoek naar de kunstmatige intelligentie, komt ook duidelijk naar voren dat ziektescript of daarmee vergelijkbare strukturen gebruikt worden voor het oplossen van de standaardproblemen. Kennis van de basisvakken is noodzakelijk voor de oplossing van de moeilijke en minder typische problemen. Dit zien we bijvoorbeeld bij een auteur als Kuipers. In het eerdere werk (Kassirer, Kuipers en Gorry, 1982) speelt deze kennis nog maar nauwelijks een rol. Het betreft hier een AI-programma dat bedoeld is om een anamnese af te nemen ten behoeve van de diagnostiek bij een patiënt met oedeem. Het programma is opgebouwd uit frames ${ }^{2}$ die alle een aandoening of een fysiologische toestand beschrijven in termen van de symptomen, de oorzaken ervoor, complicaties die kunnen optreden en de aandoeningen waarmee ze verward kunnen worden. Via de oorzaken-en complicatielinks zijn sommige frames, die deel uitmaken van dit geheel onderling verbonden. Hierdoor leidt aktivatie van het ene frame automatisch tot medeaktivatie van andere relevante frames. Toch is daarbij van causale redeneringen geen sprake. Het systeem weet immers niet waarom aandoening $A$ aandoening $B$ kan veroorzaken. In zijn recentere werk richt Kuipers zich juist op simulaties van redeneringen met deze onderliggende causale relaties. Deze causale relaties worden veelal beschreven met kennis van de basisvakken (Kuipers, 1984; Kuipers en Kassirer, 1984). In een hardop-denk onderzoek legden Kuipers en Kassirer (1984) ervaren artsen, jonge assistenten en co-assistenten een casus voor, die aangemerkt kan worden als lichtelijk atypisch. Het betreft hier een patiênt met nefrotisch syndroom bij wie een belangrijk symptoom ontbreekt. Doordat deze patiënt reeds op eigen initiatief een Natrium-beperkt dieet houdt, is er namelijk geen sprake van oedeem aan het gezicht

${ }^{1}$ D.B. Swanson, persoonlijke mededeling, 1988.

${ }^{2}$ Frame en schema zijn vrijwel identieke concepten. 
en de benen. Kuipers en Kassirer (1984) rapporteren causale redeneringen op grond van medische basiskennis bij proefpersonen van alle expertiseniveaus. In tegenstelling tot de minder ervaren proefpersonen beperkten de experts zich in hun redeneringen tot een klein aantal variabelen, die in dit geval zeer relevant waren. Kuipers en Kassirer veronderstellen dat experts beschikken over een groot arsenaal van dit soort beperkte, simpele modellen, die zij toepassen afhankelijk van de aard van het probleem en de kenmerken van de patiënt.

Ook andere ontwerpers van diagnostische expertsystemen hebben grote aandacht voor de onderliggende causale kennis. Men verwacht dat het noodzakelijk zal blijken deze 'domeintheorieën' (Steels, 1985; Mitchell, Keller en Kedar-Cabelli, 1986; Hirsch, 1987), zoals men dit soort kennis ook wel noemt, in een systeem te implementeren teneinde de moeilijkheden te omzeilen die in de huidige systemen ontstaan, wanneer ze geconfronteerd worden met problemen waarop hun diagnostische kennis niet geheel van toepassing is. Op deze manier beschouwd, is de kennis van de medische basisvakken als het ware het vangnet dat noodzakelijk is wanneer het systeem er met de gecompileerde kennis niet uitkomt.

De resultaten van Experiment 3 laten zien dat de uitbouw van de ziektescriptkennis vooral plaatsvindt in de laatste fase van de ontwikkeling tot expert. De ziektescripts die tijdens de studie worden opgebouwd, bevatten veel kennis omtrent de Consequences van een aandoening: de symptomen waaraan de patiënt lijdt. Deze kennis is echter vaak nogal rigide en is nog niet volledig afgestemd op de natuurlijke variatie in ziektebeelden, die in de praktijk gevonden wordt. Waar het de Enabling Conditions betreft, zijn ze veelal onvolledig. Deze Enabling Conditions in een ziektescript beschrijven de oorzakelijke en beperkende faktoren die bepalen dat de ene persoon wel en de andere persoon niet last krijgt van die bepaalde aandoening.

Kennis omtrent Enabling Conditions heeft meestal betrekking op gegevens over de patiënt, die vaak reeds bij de arts aanwezig zijn, hetzij in zijn of haar hoofd, hetzij in het dossier. Leeftijd, geslacht, beroep, risicofaktoren, medicijngebruik, familiaire aandoeningen, allergieën, vroegere aandoeningen en operaties zijn hiervan voorbeelden. Doordat deze gegevens vaak reeds bij de arts bekend zijn voordat de patiënt zijn of haar klacht naar voren brengt, kunnen ze in het diagnostisch proces de funktie vervullen van beperkende faktoren die van kracht zijn bij de interpretatie van de klacht van een specifieke patiënt. De Expert uit Experiment 3 beschrijft dit verschijnsel als volgt:

"Ik denk niet dat je een lijstje kunt maken waarop staat bij deze klacht horen deze differentiaal diagnostische mogelijkheden en dat geldt voor iedereen. Er is zo'n lijstje bij een bepaalde uiting, pijn in de bovenbuik bijvoorbeeld. Deze kan veroorzaakt worden door een aantal dingen, maar het hangt heel erg van een aantal andere faktoren af die je erbij moet betrekken hoe je je eigen probleemlijst of je eigen signalenlijst en overwegingen maakt. De volgorde 
(van mogelijke corzaken) verandert op basis van die andere dingen. Leeftijd speelt een heel belangrijke rol, geslacht is een heel belangrijke ${ }_{i j}$ of iemand alcohol gebruikt is een heel belangrijke faktor. Afhankelijk van het ziektebeeld zijn er een aantal faktoren die dat beïnvloeden en daardoor krijg je voor elke persoon en elke situatie een aangepaste, voor die persoon te hanteren lijst (van hypothesen)."

Schmidt, Hobus, Patel en Boshuizen (1987) onderzochten dit gebruik van kennis van Enabling Conditions bij net afgestudeerde basisartsen en bij huisartsen met tenminste vier jaar ervaring. Deze proefpersonen kregen steeds een serie van drie dia's aangeboden waarop achtereenvolgens de groene kaart van de patiënt werd getoond, een portretdia en een weergave van de klacht, die door de patiënt werd geuit. Uit de resultaten bleek uit de hoeyeelheid informatie die men zich nog kon herinneren, dat de ervaren huisartsen in tegenstelling tot de basisartsen duidelijk gebruik maakten van de gegevens die betrekking hebben op de Enabling Conditions. In een vervolgexperiment (Hobus, Hofstra, Boshuizen en Schmidt, 1988) werden weer de diagnostische prestaties van huisartsen en basisartsen met elkaar vergeleken. Nu kreeg de helft van deze proefpersonen wel de informatie over de patiënt in de vorm van een groene kaart en portret te zien, terwijl aan de andere helft slechts de klacht werd voorgelegd. Het bleek dat in beide gevallen de huisartsen betere hypothesen produceerden dan de basisartsen, maar dat daarbij de huisartsen sterk profiteerden van de aanwezigheid van informatie over de patiënt, terwijl dit bij de basisartsen geenszins het geval was.

In het medische curriculum wordt de kennis omtrent Enabling Conditions veel minder systematisch aangebracht dan de kennis van de Consequences van een aandoening. Hieruit vloeit voort dat juist om de kennis omtrent Enabling Conditions goed te leren gebruiken een student of een arts veel patiënten moet 'zien'. Hij of zij moet veel anamneses afnemen, lichamelijk onderzoek doen, diagnosticeren en behandelen. Studenten kunnen deze ervaringen eerst opdoen in de beschermde omgeving van de opleidingssituatie, waar zij kunnen oefenen met papieren simulaties, met computersimulaties of simulatiepatiënten ${ }^{3}$ en later, onder begeleiding, bij echte patiënten. Door het contact met de patiënt en door het toepassen van de kennis ontwikkelt men de kennis en de vaardigheden waarop expertise in belangrijke mate stoelt. Onderzoek van Hofstra, Hobus, Boshuizen en Schmidt (1988) laat ook zien dat er zelfs na 15 jaar ervaring als arts nog sprake is van een toenemende vaardigheid in het gebruik van Enabling Conditions bij het diagnosticeren van een patiënt.

${ }^{3}$ Dit zijn gezonde personen die speciaal ten behoeve van het onderwijs spelen dat ze een bepaalde aandoening hebben. 


\section{EVALUATIE}

Theorie en empirische ondersteuning daarvoor overziend, komen we tot de conclusie dat de theorie in twee aspekten in voldoende mate door de empirie wordt onderbouwd. Het betreft het gebruik van ziektescripts door experts bij het diagnosticeren van een probleem en de compilatie van de kennis van de medische basisvakken. Onvoldoende duidelijk is nog hoe dan de ziektescripts worden gevormd en hoe de gecompileerde (patho)fysiologische en anatomische kennis daarin geincorporeerd wordt. Het heeft er alle schijn van dat het niet zo'n automatisch werkend mechanisme is als eerder in dit proefschrift werd aangenomen.

De hele theorie vertoont echter een opmerkelijk hiaat. Er werd aangegeven dat het contact met de patiënt een belangrijke funktie vervult in het vormen van rijke en flexibele ziektescripts. Maar het contact met patiênten heeft wellicht nog een andere funktie, waaraan we tot nu toe voorbij zijn gegaan. Stel, dat een arts op een dag ongeveer 20 patiënten ziet die hem of haar komen raadplegen in verband met een klacht. Dat betekent dat hij of zij ongeveer 4600 patiënten per jaar ziet. Van al deze patiënten worden in het episodisch geheugen geheugensporen opgeslagen (Tulving, 1972). Hoe veel er van iedere patiënt of van ieder consult onthouden wordt, hangt van allerlei zaken af: de epidemiologische situatie, de moeilijkheid van het probleem dat gepresenteerd wordt, mogelijke diagnostische fouten die de arts eerder met een vergelijkbare klacht heeft gemaakt, of de persoon van de patiënt. Een arts zal niet alle kindertjes met ontstoken oren onthouden, die hem in de winter worden gepresenteerd. Maar niet vergeten wordt die mevrouw uit Trois Iles die aan de ziekte van Crohn leed ${ }^{4}$, maar zich drukker maakte over haar borsten, die ze te klein vond, dan over haar ziekte. Ook de mevrouw die hevige buikkrampen had en in partu bleek zonder dat zij zelf wist dat ze zwanger was 5 , wordt altijd onthouden. Hetzelfde geldt voor die vreemde meneer die heel veel dronk en allemaal schimmel in zijn mond had. De diagnose 'diabetes' werd echter in eerste instantie gemist, omdat de communicatie met de assistente verkeerd was gelopen. Hierdoor had de arts gedacht dat er urineonderzoek op suikerziekte was gedaan dat niets had opgeleverd. Daardoor had het veel te lang geduurd voordat de diagnose gesteld werd en overleed de patiënt (Conradi, 1987). De herinneringen aan de emotioneel geladen gebeurtenissen (Kleinsmith en Kaplan, 1963) en aan de contacten waarin veel werd geëlaboreerd en veel cognitieve inspanning werd verricht (Craik en Jacoby, 1979), vormen in dit geheel van herinneringen de meer opvallende elementen.

${ }^{4} \mathrm{G}$. Bordlage, persoonlijke mededeling, 1985 . Zij was de eerste patiênte met de ziekte van Crohn die hij in 1972 ontmoette.

5V. Kaiser, persoonlijke mededeling, 1987. 
Schmidt en Norman (1989) betogen dat deze bibliotheek van individuele patiënten een derde kennislaag vormt die aan het model van de ontwikkeling van medische expertise moet worden toegevoegd. Zij verwijzen daarbij naar het werk van Brooks (in voorbereiding). Brooks en zijn medewerkers hebben een aantal ingenieuze experimenten gedaan waarin zij het effekt nagingen van eerdere ervaringen op de cognitieve verwerking van nieuwe informatie. Zij maakten daarbij onderscheid tussen nieuwe informatie die gelijk is aan eerder verwerkte informatie, nieuwe informatie die van dezelfde klasse is en er erg veel op lijkt, en nieuwe informatie die er er minder op lijkt. Dit deden zij door mensen bekende voorwerpen te laten benoemen. In de testfase, die enige tijd later volgde, lieten zij drie typen voorwerpen zien: identieke voorwerpen, goed gelijkende voorwerpen en voorwerpen uit dezelfde categorie die er duidelijk van afweken. De identieke voorwerpen werden het snelst herkend. Goed gelijkende voorwerpen uit dezelfde klasse werden minder snel benoemd en de groep die het minst leek op de proefserie nam de meeste benoemingstijd in beslag. De onderzoekers konden aantonen dat dit effekt zich over zeer lange tijdsperiodes uitstrekt. Aangezien het in dit experiment ging om het benoemen van zeer bekende voorwerpen als kopjes en bekers luidde Brooks' conclusie, dat het verrichten van een categorisatietaak (de beoordeling tot welke klasse een voorwerp of een gebeurtenis behoort) in veel gevallen niet uitsluitend gebaseerd is op de toepassing van algemene kennis, maar op het gebruik van de geheugensporen van eerdere ervaringen. Een replicatie van dit experiment in het medisch domein (Norman, Brooks, Allen en Rosenthal, 1988) laat zien dat dezelfde processen ook in de geneeskunde werkzaam zijn.

Het feit dat de huidige patiënt herinneringen oproept aan een patiënt die de arts gisteren, een week geleden of misschien wel meerdere jaren geleden heeft ontmoet, verschaft hem een snelle toegang tot de relevante kennis (Schmidt en Norman, 1988). Dit mechanisme verhoogt niet alleen de snelheid van het zoekproces, het kan soms ook de enige wijze zijn om tot een juiste diagnose te komen. Dit effekt zal, naar wij vermoeden, vooral optreden wanneer door preventie, veranderde behandelingsmethoden of door veranderingen in de levensomstandigheden bepaalde ziekten in een populatie vrijwel verdwenen zijn.

Ter illustratie geven we het volgende voorbeeld6. Bij een psychologisch instituut wordt een onderzoek aangevraagd voor een dame die meent restverschijnselen te hebben overgehouden aan een auto-ongeluk. De dame in kwestie is een jaar of vijftig die zich wat buitenissig kleedt. Ze maakt een vrolijke, ietwat theatrale indruk. De psycholoog die haar test komt tot de conclusie dat er inderdaad iets aan de hand is met haar geheugen, maar wat precies is hem niet duidelijk. Bij een woordparenleertest is zij niet in staat zich de relaties tussen de aangeboden woorden te herinneren, maar de woorden zelf blijken perfekt onthouden te worden.

6A.E. Akkerman, persoonlijke mededeling, 1986. 


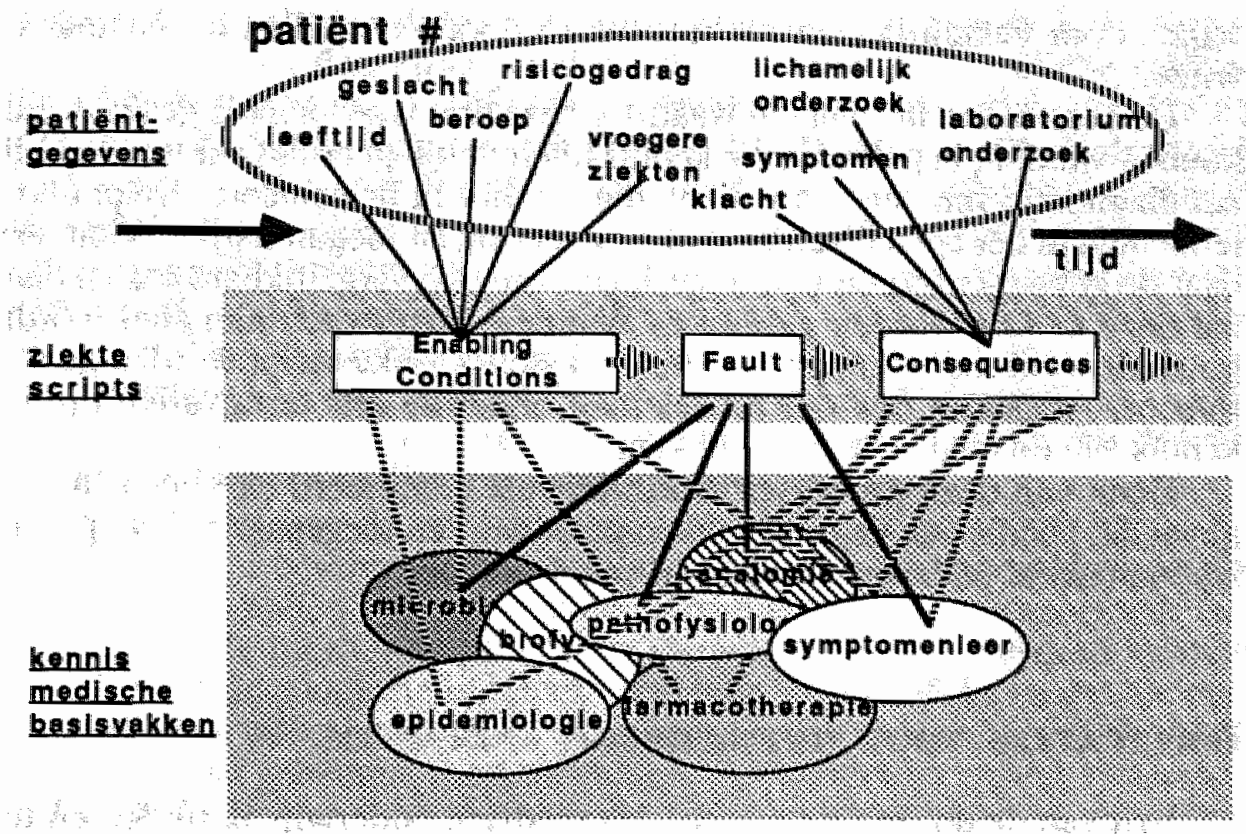

Figuur 5,1 Model van de kennis van de medisch expert uitgebreid met een derde, episodische laag waarin de geheugensporen van contacten met concrete patienten worden gerepresenteerd (met toestemming overgenomen van Hobus, 1988).

De verzekeringsarts die haar daarna ziet, herkent in haar het beeld van een cerebrale syphilis, zodat de claim niet wordt toegewezen. Deze arts is in het eerste deel van zijn loopbaan huisarts geweest in Amsterdam (naar schatting vanaf 1942), in welke periode hij ook patiënten met syphilis in zijn praktijk had. Huisartsen en neurologen anno 1989 komen het beeld nog maar zeer zelden tegen (Sacks, 1985).

Een ander, minder dramatisch voorbeeld is de diagnostiek van kinkhoest. Sinds het eind van de jaren ' 50 kwam deze ziekte in Nederland niet meer voor. De eerste gevallen die zich enige tijd geleden voordeden, nadat op een minder werkzaam vaccin was overgegaan, waren voor de jongere huisartsen moeilijk herkenbaar. Vaak zullen de grootouders van de getroffen kinderen eerder hebben doorgehad wat er aan de hand was. Een uitgebreid kennisbestand dat de herinneringen bevat aan eerdere patiënten, vormt dus een zeer belangrijk hulpmiddel voor de arts.

Deze laatste overwegingen hebben tot gevolg dat we het ontwikkelingsmodel van medische expertise, dat in de voorafgaande hoofdstukken werd ontvouwd, op één belangrijk punt moeten bijstellen. We nemen nu aan dat de kennis van de expert in de geneeskunde niet bestaat uit twee onderling verbonden kennislagen, maar is opgebouwd uit drie onderling verbonden kennislagen: de kennis van de medische basisvakken, de ziektescripts en de herinneringen aan concrete patiënten (zie Figuur 5.1). Deze drie kennislagen worden gekenmerkt door verschillen in representatie- 
wijze, door verschillen in zoekproces en door verschillen in ontstaanswijze.

De verschillen in snelheid waarmee deze drie typen kennis geaktiveerd kunnen worden, bepalen welke kennis uiteindelijk gebruikt zal worden bij het diagnosticeren van een patiënt, die een klacht presenteert. De patiëntenkennis in het episodisch geheugen is het snelst toegankelijk. Wanneer daar de geheugensporen zijn opgeslagen van een vergelijkbare casus, dan zal deze kennis worden gebruikt. Wanneer zo'n match niet snel wordt gevonden, zal indien mogelijk een toepasselijk ziektescript worden geaktiveerd. Wanneer ook dat proces faalt, moet de arts terugvallen op de kennis van de medische basisvakken.

Geen van deze processen wordt bewust geïnitieerd en alleen in het geval dat kennis van de basisvakken moet worden toegepast, zal er sprake zijn van aktief en bewust toepassen van de kennis.

\section{IMPLICATIES VOOR HET MEDISCH ONDERWIJS}

Eén van de doelstellingen van het medisch onderwijs is studenten te leren medische problemen op te lossen. Dit leren probleemoplossen in de geneeskunde kan vanuit meerdere gezichtspunten worden benaderd (Boshuizen en Claessen, 1982). De eerste, meest voorkomende benadering gaat uit van het probleem dat de patiënt heeft en dat de arts of de student moet oplossen. In deze optiek is de interaktie met de patiënt heel belangrijk. Hierin moet immers worden achterhaald wat nu eigenlijk het probleem is dat de patiënt kwelt. Onderwijsprogramma's die dit uitgangspunt hanteren, benadrukken eerder de sociale vaardigheden dan de cognitieve vaardigheden, die voor het oplossen van problemen noodzakelijk zijn.

In de andere benadering van leren probleemoplossen wordt uitgegaan van het (cognitieve) probleem van de arts, namelijk het diagnosticeren van de aandoening waaraan de patiênt lijdt, die hem of haar komt raadplegen. Vaak werd aangenomen dat het onderwijs daarin geen speciale taak heeft. Studenten zouden dat wel vanzelf leren in de praktijk, nadat ze eenmaal alle kennis hadden verworven. Een andere opstelling is te vinden bij Elstein, Shulman en Sprafka (1978), die probeerden studenten te trainen in het oplossen van diagnostische problemen door ze algemene probleemoplossingsheuristieken te leren.

De theorie die in dit proefschrift is gepresenteerd, sluit aan bij de laatste opvatting van probleemoplossen als cognitief probleem van de arts. De gekozen invalshoek is echter een heel andere. In dit proefschrift is betoogd dat de struktuur van de kennis die tijdens het ontwikkelingsproces van beginner tot expert wordt opgebouwd van doorslaggevend belang is voor het kunnen oplossen van problemen. De student verwerft eerst in een proces van voortdurende uitbouw, onderbroken door periodes van herstrukturering een bestand van kennis van de medische basisvakken, 
waarin de kennis van deze vakken met elkaar is geîntegreerd. Deze periodes van herstrukturering worden gekenmerkt door plotselinge vergroting van het inzicht. Ze zijn een noodzakelijke voorwaarde om daarna weer nieuwe kennis op te kunnen doen. Bij de succesvolle student ontstaat op deze wijze een kennisbestand dat samenhangend en betrouwbaar is, maar dat moeilijk toepasbaar is. Deze geëlaboreerde kennis wordt vervolgens, door de toepassing ervan in de praktijk, gecompileerd en geintegreerd in ziektescripts. Deze ziektescripts worden verrijkt met relevante patiëntenkenmerken en onder invloed van de natuurlijke variaties in het betreffende ziektebeeld worden ze meer flexibel. Compilatie, verrijking en aanpassing aan de natuurlijke variaties zorgen ervoor dat de kennis steeds beter en sneller toepasbaar wordt.

Het model van de ontwikkeling van medische expertise, dat in dit proefschrift is beschreven, zou wellicht de indruk kunnen wekken dat als er maar veel patiëntcontacten in het curriculum worden ingebouwd, een aantal van de hierboven geschetste ontwikkelingen bevorderd kunnen worden. Deze conclusie is echter voorbarig. We merkten op dat het vervolmaken en uitbouwen van de ziektescripts voor een groot gedeelte in de praktijk moet gebeuren, mede doordat in het onderwijs weinig systematische aandacht wordt besteed aan de Enabling Conditions in de ziektescripts. Vakken als psychologie, sociologie, farmacologie, epidemiologie en arbeidsgeneeskunde nemen in de meeste medische curricula slechts een bescheiden plaats in. Van integratie met de meer toegepaste medische vakken zal nog minder sprake zijn. Het verdient daarom aanbeveling studenten te confronteren met taken waarin de geîntegreerde bestudering en toepassing van kennis omtrent Enabling Conditions en Consequences noodzakelijk is. Deze integratie zou zo vroeg mogelijk in het curriculum moeten plaatsvinden en moeten worden nagestreefd in alle gebruikte onderwijsvormen.

Ook de compilatie van de geèlaboreerde kennis verdient meer aandacht dan ze nu krijgt. In dit verband is het nuttig het onderzoek van Lemieux en Bordage (1986) te memoreren. Zij deden onderzoek naar de kennisstruktuur en het kennisgebruik van artsen en van goede en minder goede studenten. De artsen pasten gecompileerde kennis toe. De goede studenten bleken uitgebreide elaboraties op hun kennis uit te voeren en op die manier een verklaring te construeren voor wat er met de patiënt aan de hand zou kunnen zijn. Bij de minder goede studenten viel het op, dat zij probeerden een hypothese omtrent de aard van de aandoening van de patiènt te genereren zonder daarbij allerlei onderliggende kennis over anatomie en fysiologie te aktiveren. Juist dit 'pseudo-expert'gedrag achten Lemieux en Bordage contraproduktief in het leerproces dat verder nog moet plaatsvinden, omdat het leidt tot geisoleerde, oppervlakkige kennis. 
Eén van de deelnemers aan een onlangs in Londen gehouden symposium rond kennisstrukturen en medisch probleemoplossen 7 merkte op dat hijzelf de neiging had om díe co-assistenten hoog aan te slaan die smel allerlel (soms zeer wilde) hypothesen konden genereren omtrent een mogelijke diagnose van de patiënt. Vaak waren dit hypothesen waaraan hij zelf niet had gedacht, maar waar bij nadere beschouwing soms wel iets inzat. "Misschien", zei hij, "roep ik daarmee wel volkomen verkeerd gedrag op bij de studenten." Inderdaad is het zeer wel mogelijk dat de student op deze wijze verlokt wordt tot pseudo-expertgedrag op een ogenblik dat de omvang en de struktuur van de aanwezige kennis dat zeker nog niet toelaten. In deze fase zou het voor de studenten veel nuttiger zijn, wanneer zij in de gelegenheid worden gesteld hun geëlaboreerde kennis van de medische basisvakken toe te passen op het probleem waarmee ze worden geconfronteerd. Alleen op deze wijze kunnen garanties worden geschapen dat de resulterende gecompileerde kennis juist is. Hierdoor wordt de uitbouw van de ziektescripts bevorderd én het resulterende episodisch geheugenspoor kan in de toekomst een snellere toegang tot de relevante kennis opleveren.

De onderzoekingen die in dit proefschrift zijn gepresenteerd, bestudeerden probleemoplossen en de ontwikkeling van de kennis met behulp van casusbeschrijvingen. Medisch probleemoplossen in de praktijk vraagt van een arts of een student andere akties dan het doorlezen van een casus. De vraag van de patiënt moet verhelderd worden. Nadat hypothesen zijn gegenereerd moeten vragen en onderzoekingen worden geselekteerd die deze hypothesen kunnen bevestigen danwel falsifiëren. Deze vragen moeten vervolgens worden gesteld, de onderzoekingen moeten worden uitgevoerd en de verkregen informatie moet worden geinterpreteerd. Tenslotte moeten er conclusies worden getrokken omtrent de juistheid van de gestelde hypothesen. En dat is niet het enige.

Bij experts zijn deze aktiviteiten goed gecoördineerd, dankzij de ziektescripts waarover ze beschikken. Studenten daarentegen moeten niet alleen elaboreren op hun kennis om hypothesen te genereren, maar ook om relevante vragen te bedenken en om conclusies te trekken. Dit zijn bij elkaar zeer veel taken die gecoördineerd moeten worden uitgevoerd. Voeg daarbij de sociale en ethische eisen die gesteld worden aan de interaktie met een patiënt, en het beeld dat Elshout ${ }^{8}$ eens schetste van de Chinese jongleur die het net niet kan bijbenen om alle bordjes op de stokjes

\footnotetext{
${ }^{7}$ Greenwich Symposium on Diagnostic Thinking, 10 en 11 maart 1988, georganiseerd door G. Bordage, Ph. Marsden en J. Gale Grant. Dit symposium was erop gericht de huidige inzichten in medisch probleemoplossen en de relatie met de ontwikkeling van de kennis te Loetsen aan de ervaring van een aantal Britse artsen die praktisch medisch onderwijs in de kliniek verzorgen.

${ }^{8}$ Elshout gebruikte deze metafoor eens tijdens een college cognitie. Hij noch de auteur van dit proefschrift kunnen zich herinneren wanneer dit precies geweest is.
} 
draaiende te houden, is compleet. De ervaring is dan ook dat derdejaars en vierdejaars studenten tijdens een consult met een patiënt of een simulatiepatiënt een aantal van de genoemde aktiviteiten niet ontplooien.

Er moeten dus wegen worden gevonden om te leren deze vaardigheden, die studenten meestal wel geisoleerd kunnen uitvoeren, in combinatie met elkaar toe te passen. Collins, Brown en Newman (1988) beschrijven een aantal onderwijsmethoden, die zij samenbrengen onder de term cognitive apprenticeship'. Een 'apprenticeship' is een leertijd waarin een vak in de praktijk geleerd wordt. Voor de ambachten is deze wijze van leren een normale situatie. In de vakgebieden waarin veel kennis vergaard moet worden, is het tegenwoordig veel meer gebruikelijk dat het vak in een speciale school geleerd wordt. De leersituatie wordt dus losgemaakt van de praktijk. Collins et al. (1988) pleiten ervoor de praktijk terug te brengen in de leersituatie.

Cognitive apprenticeship kent drie kemelementen. Het eerste kenmerk is Modeling: de expert laat zien hoe hij of zij te werk gaat met de bedoeling de student in de gelegenheid te stellen een goed beeld te vormen van de vaardigheden, de deelvaardigheden en hun onderlinge samenhang. Het tweede kenmerk wordt gevormd door Scaffolding. Onder scaffolding wordt verstaan dat de student nu zelf de te leren vaardigheid gaat oefenen met hulp van de expert. Het derde kenmerk tenslotte bestaat uit Fading. Bij het oefenen wordt de hulp langzaamaan verminderd, totdat de student de vaardigheid tenslotte zelfstandig kan uitvoeren.

Deze methode kan niet zonder aanpassingen worden toegepast bij het leren van medisch probleemoplossen. Medisch probleemoplossen is immers een proces dat zich inwendig voltrekt. Zonder nadere maatregelen 'ziet' een student daar dus niets van. Zo'n speciale maatregel zou eruit kunnen bestaan dat de arts een consult met een patiënt hardop denkend uitvoert. Zoiets is natuurlijk niet mogelijk in een echte consultsituatie, maar in een rollenspel van een arts met een simulatiepatiënt kan het wel verwezenlijkt worden. Een arts kan daarin verschillende modi van kennisgebruik laten zien: gebruik van ervaringen met eerdere patiênten, gebruik van ziektescriptkennis en gebruik van medische basiskennis. De expert kan ook laten zien welke vragen hij/zij kiest bij de verschillende hypothesen die bij hem of haar opkomen. Op de volgende punten zou de student hulp bij het oefenen kunnen krijgen: bij het struktureren van de informatie die afkomstig is uit anamnese, lichamelijk onderzoek en laboratoriumonderzoek; bij het interpreteren van die informatie met behulp van ziektescriptkennis of met behulp van de kennis van de basisvakken; en bij de keuze van relevante vragen en onderzoekingen.

Verder benadrukken Collins et al. (1988) dat het welslagen van het leren van complexe cognitieve vaardigheden bevorderd kan worden door de aan te leren deelvaardigheden in verschillende combinaties met elkaar te laten oefenen. De resultaten van de onderzoekingen die in dit proefschrift zijn beschreven, suggereren een aantal nuttige oefeningen. Er kan bijvoorbeeld gedacht worden aan oefeningen in het analyseren van gegevens over de context van de patiënt teneinde daarin Enabling Conditions voor 
bepaalde aandoeningen te identificeren. Oefeningen die erop zijn gericht om de kennis van de basisvakken beter te integreren met de ziektescripts, zouden kunnen bestaan uit een beschrijving van een pathofysiologisch proces, waarbij de student de opdracht krijgt zo veel mogelijk verschillende verschijningsvormen van deze aandoening te bedenken, daarbij rekening houdend met bijvoorbeeld de leeftijd van de patiënt of met zijn of haar algehele gezondheidstoestand. Op deze wijze ontwikkelt de student één of meer goed gefundeerde prototypen voor een ziektebeeld, waarnaast in een later stadium de natuurlijke variaties een plaats kunnen krijgen (Bordage en Zacks, 1984). Voorkomen moet echter worden dat variaties binnen een ziektebeeld in een te vroeg stadium van de ontwikkeling aan de orde komen. Pas als er een goed ankerpunt aanwezig is, zijn variaties niet meer verwarrend. Een grotere integratie en samenhang tussen ziektescripts kan wellicht bevorderd worden door de studenten te confronteren met een aantal casusbeschrijvingen van ziektebeelden die gemakkelijk met elkaar verward kunnen worden, waarbij ze de opdracht krijgen de onderliggende processen te beschrijven. Veel van deze oefeningen lenen zich uitstekend voor een computerondersteunde aanbiedingswijze. 


\section{REFERENTIES}

Ackermann, W. \& Barbichon, G. (1963). Conduites intellectuelles et activite technique. Bulletin CERP, 12, 1-16.

Allwood, C.M. \& Montgomery, H. (1982). Detection of errors in statistical problem solving. Scandinavian Journal of Psychology, 23, 131-140.

Allwood, C.M. \& Montgomery, H. (1981). Knowledge and technique in statistical problem solving. European Journal of Science Education, 3, 431-450.

Anderson, J.R. (1982). Acquisition of cognitive skill Psychological Review, 89, 369406.

Anderson, J.R. (1983). The architecture of cognition. Cambridge, MA: Harvard University Press.

Anderson, J.R. (1985). Cognitive psychology and its implications. New York: Freeman.

Anderson, J R. \& Bower, G.H. (1973). Human Associative Memory. Washington, DC: V.H. Winston.

Anderson, J.R. (1987). Skill acquisition: Compilation of weak-method problem solutions. Psychological Review, 94, 192-210.

Anderson, R.C., Reynolds, R.E., Schallert, D.L. \& Goetz, E.T. (1977). Frameworks for comprehending discourse. American Educational Research Journal, 14, 367.381.

Anderson, R.C. (1977). The notion of schemata and the educational enterprise. In: Anderson, R.C., Spiro, R.J. \& Montague, W.E. (Eds.), Schooling and the acquisition of knowledge. Hillsdale, NJ: Erlbaum.

Barclay, J.R. (1973). The role of comprehension in remembering sentences. Cognitive Psychology, 4, 229-254.

Barrows, H.S., Feightner, J.W., Neufeld, V.R. \& Norman, G.R. (1978). An analysis of the clinical method of medical students and physicians. Hamilton, Ontario, Canada: McMaster University.

Bhaskar, R. \& Simon, H.A. (1977). Problem solving in semantically rich domains: An example from engineering thermodynamics. Cognitive Science, 1, $193-215$

Birch, H.G. \& Rabinovich, H.S. (1951). The negative effect of previous experience on productive thinking. Journal of Experimental Psychology, 41, 121-125.

Bloom, B.S. \& Broder, L.J. (1950). Problem solving processes of college students. Chicago, IL: University of Chicago Press.

Bordage, G. \& Zacks, R. (1984). The structure of medical knowledge in the memories of medical students and general practitioners: Categories and prototypes. Medical Education, $_{18}$, 406-416. 
Boshuizen, H.P.A. \& Claessen, H.F.A. (1981). De cognitieve verwerking van medische gegevens door artsen en studenten. (Onderzoek van Onderwijs RL 10). Maastricht: O\&O, RL.

Boshuizen, H.P.A. \& Schmidt, H.G. (1989, in druk). The developing structure of medical knowledge. In: Schmidt, H. G., Nooman, Z. \& Ezzat, E. (Eds.), Innovation in Medical Education: An evaluation of its present staus. New York: Springer.

Boshuizen, H,P.A. Schmidt, H.G.\& Coughlin, L.D. (1988). On the application of basic-science knowledge in clinical reasoning: Implications for structural differences in knowledge between experts and novices. Proceedings of the 10th Annual Conference of the Cognitive Science Society. Hillsdale, NJ: Erlbaum.

Boshuizen, H.P.A., Schmidt, H.G. \& Coughlin, L.D. (1987). On-line representation of a clinicall case and the development of expertise. Paper presented at the AERAConference. Washington, DC.

Boshuizen, H.P.A. \& Claessen, H.F.A. (1982). Problems of research into medical problem-solving; Some remarks on theory and method. Medical Education, 16, 81-87.

Bouwman, MJ. (1980). The use of accounting information: Expert versus novice behavior. Unpublished doctoral dissertation, University of Oregon.

Bower, G.H., Monteiro, K.P. \& Gilligan, S.G. (1978). Emotional mood as a context for learning and recall. Journat of Verbal Learning and Verbal Behavior, 17, 573-587.

Bower, G.H. (1978). Experiments on story comprehension and recall. Discourse Processes, $3,211-232$.

Bransford, J.D. \& Franks, J.J. (1971). The abstraction of linguistic ideas. Cognitive Psychology, 2, 331-350.

Bransford, J.D. \& Franks, J.J (1972). The abstraction of linguistic ideas: A review. Cognition $1,211-249$.

Bransford, J.D. \& Johnson, M.K. (1972). Contextual prerequisites for understanding: Some investigations of comprehension and recall. Journal of Verbal Learning and Verbal Behavior, 11,717-726.

Bransford, J.D., Barclay, J.R. \& Franks, JJ. (1972). Sentence memory: A constructive versus interpretive approach. Cognitive Psychology, 3, 193-209.

Bransford, J.D., Sherwood, R., Vye, N. \& Rieser, J. (1986). Teaching thinking and problem solving. American Psychologist, 41, 1078-1089.

Braunwald, E., Isselbacher, K.J., Petersdorf, R,G., Wilson, J.D., Martin, J.B. \& Fanci, A.S. (1987). Harrison's principles of internal medicine. New York, NY: McGraw-Hill.

Braunwald, E. (1988). Heart Disease. Philadelphia, PA: Saunders.

Breuker, J.A., Elshout, J.J., Van Someren, M.W. \& Wielinga, B.J. (1986). Hardopdenken en protocolanalyse. Tijdschrift voor Onderwijsreseach, 11, 241-254.

Brown, A.L. (1978). Knowing when, where and how to remember: A problem of metacognition. In: Glaser, R. (Ed.), Advances in instructional psychology. Vol. 1 Hilsdale, NJ: Erlbaum.

Bryan, W.L. \& Harter, N. (1899). Studies on the telegraphic language: The acquisition of a hierarchy of habits. Psychological Review, 6, 346-375.

Chase, W. G \& Simon, H.A. (1973a). The mind's eye in chess. In Chase, W.G. (Ed.), Visual information processing. New York. Academic Press.

Chase, W.G. \& Simon, H.A. (1973b). Perception in chess. Cognitive Psychology, 4, 55-81.

Chi, M.T.H., Feltovich, P.J. \& Glaser, R. (1981). Categorization and representation of physics problems by experts and novices. Cognitive Science, $5,121-152$.

Chi, M.T.H., Glaser, R. \& Rees, M. (1982). Expertise in problem solving. In Sternberg, R. (Ed.), Advances in the psychology of human intelligence. Vol. 1. Hillsdale, NJ: Erlbaum. 
Claessen, H.F.A. \& Boshuizen, H.P.A. (1985), Recall of medical information by students and doctors. Medical Education, 19,61-67.

Collins, A., Brown, J.S. \& Newman, S. E. (in druk), Cognitive apprenticeship. Teaching the craft of reading, writing and mathematics. In: Resnick, L.B. (Ed), Cognition and instruction Issues and agendas. Hillsdale, NJ: Erlbaum.

Conradi, M. (1987). Fouten van huisartsen; Een exploratief onderzoek naar medische fouten van huisartsen, en het gedrag van artsen na een fout. (doctoraal scriptie medische sociologie). Groningen: Rijksuniversiteit Groningen.

Cooke, N. \& McDonald, J.E. (1986). A formal methodology for acquiring and representing expert knowledge. In: Proceedings of the IEEE, Vol. 74 .

Coughlin, L.D. \& Patel, V.L. (1987). Processing of critical information by physicians and medical students. Medical Education, 62, 818-828.

Coughlin, L.D. \& Patel, V.L. (1986). Text comprehension and expertise in the domain of medicine. Paper presented at the AERA-Conference. San Francisco.

Craik, F.I.M. \& Jacoby, L.L. (1979). Elaboration and distinctiveness in episodic memory. In: Nilsson, L.-G. (Ed.), Perspectives in memory research. Hillsdale, NJ: Erlbaum.

Crombag, H.F.M., Wijkersloot, J.L. de \& Cohen, MJ. (1977). Een theorie over rechterlijke beslissingen. Groningen: Tjeenk Willink.

Danner, S.A., Wieling, W., Roos, C.M. \& Dunning, AJ. (1981). Bacterielle endocarditis bij drugsgebruikers. Nederlands Tijdschrift voor de Geneeskunde, 125, 369-375.

Dijk, T.A. van \& Kintsch, W. (1983). Strategies of discourse comprehension New York: Academic Press.

Dooling, D. J. \& Lachman, R. (1971). Effects of comprehension on retention of prose. Journal of Experimental Psychology, 88, 216-222.

Elshout, J J (1983). Een beginner is meer dan iemand die het nog niet kan. In: Drenth, P.J.D., Koops, W., Orlebeke, J.F. \& Takens, R.J. (Eds.), Psychologie in Nederland: Enkele ontwikkelingen in 1982. Lisse: Swets en Zeitlinger.

Elshout, J.J. \& Wielinga, B. (1978). Leren probleemoplossen. In: Kanselaar, G. \& Peeck, J. (Eds), Strategieën in leer-en onderwijsprocessen. (pp. 78-90). Den Haag: SVO.

Elshout, J.J. (1987). Probleemoplossen als context voor leren probleemoplossen. Nederlands Tijdschrift voor de Psychologie, 42, 344-353.

Elstein, A.S., Shulman, L.S. \& Sprafka, S.A. (1978). Medical problem solving. An analysis of clinical reasoning. Cambridge, MA: Harvard University Press.

Epen, J.H. (1983). Drugsverslaving en alcoholisme. Amsterdam: Elsevier.

Ericsson, K.A. \& Simon, H.A. (1984). Protocol analysis; Verbal reports as data. Cambridge, MA: MIT Press.

Feltovich, P.J. \& Barrows, H.S. (1984). Issues of generality in medical problem solving. In: Schmidt, H.G. \& De Volder, M.L. (Eds.), Tutorials in problem-based learning; A new direction in teaching the health professions. Assen Van Gorcum.

Feltovich, P.J., Johnson, P.E., Moller, J.H. \& Swanson, D.B. (1984). LCS: The role and development of medical knowledge in diagnostic expertise. In: Clancey, W. J. \& Shortliffe (Eds.), Readings in medical artificial intelligence, The first decade. Cambridge MA: Addison-Wesley.

Fitts, P.M. (1964). Perceptual-motor skill learning. In: Melton, A.W. (Ed.), Categories of human learning. New York Academic Press.

Frederiksen, C.H. (1975). Representing logical and semantic structures of knowledge acquired from discourse. Cognitive Psychology, 7, 371-458. 
Friedman, R.B., Newsom, R.S. \& Entine, S.M. (1977). A simulated patient-physician encounter using a talking computer. Journal of the American Medical Association. $238,1927-1929$.

Frijda, N.H. (1978). Memory processes and instruction. In: Lesgold, A.M., Pellegrino, J.W., Fokkema, S.D. \& Glaser, R. (Eds.), Cognitive psychology and instruction. New York: Plenum Press.

Frijda, N.H. \& Elshout, J.J. (1976). Probleemoplossen en denken. In: Michon, J.A., Eijkman, E.G.J. \& Klerk, L.F.W. de (Eds.), Handboek der psychonomie. Deventer: Van Lochum Slaterus.

Gale, J. \& Marsden, P. (1982). Clinical problem solving: The beginning of the process. Medical Education, 16, 22-26.

Garnham, A. (1981). Mental modells as representations of texts. Memory and Cognition, $9,560-565$.

Gerritsma, J.G.M. \& Smal, J.A. (1982). De werkwijze van huisarts en internist, Een vergelijkend onderzoek met behulp van een interaktieve patiëntensimulatie. Utrecht: Wetenschappelijke Uitgeverij Bunge.

Gitomer, D.H. \& Glaser, R. (in druk). Knowlegde, selfregulation and instruction. In: Snow, R.E. \& Farr, MJ. (Eds.), Aptitude learning and instruction. Hillsdale, NJ: Erlbaum.

Glaser, R. (1984), Education and Thinking. American Psychologist, 39, 93-104.

Glaser, R. (1986), On the nature of expertise. In: Klix, F. \& Hagendorf, H. (Eds.), Human memory and cognitive capabilities; Mechanisms and performances; Vol. 2. Amsterdam: Elsevier Science - North Holland.

Godden, D.R. \& Baddeley, A.D. (1975). Context-dependent memory in two natural environments: on land and underwater. British Journal of Psychology, 66, 325-331.

Grant, J. \& Marsden, P. (1988). Primary knowledge, medical education and consultant expertise. Medical Education, 22, 746-753.

Grant, J. \& Marsden, P. (1987). The structure of memorized knowledge in students and clinicians: An explanation for diagnostic expertise. Medical Education, 21, 92-98.

Groot, A.D. de (1946). Het denken van den schaker. Den Haag: North-Holland.

Groot, A.D. de (1965). Thought and choice in chess. The Hague: Mouton.

Groot, A.D. de (1981). Thought and choice in chess; An overview of a study based on Selzian theory. In: Frijda, N.H. \& De Groot, A.D. (Eds.), Otto Seltz, his contribution to psychology: Den Haag: Mouton.

Groen, G.J. \& Jemey, J.P. (1987). From children's arithmetic to medical problem solving: An extension of the Kintsch-Greeno model. Paper presented at the AERA-Conference: Washington, $\mathrm{DC}$.

Groen; G.J. \& Patel, V.L. (in druk). The relationship between comprehension and reasoning in medical expertise. In: Chi, M.T.H., Glaser, R. \& Farr, M. (Eds.), The nature of expertise. Hillsdale, NJ: Erlbaum.

Hassebrock, F. \& Prietula, M.J. (1986). A protocol-based coding scheme for the analysis of medical reasoning. Paper presented at the 8th Annual Meeting of the Society for Medical Decision Making. Chicago, IL.

Hassebrock, F., Bullemer, P. \& Johnson, P.E. (1988). When less is more: selective memory of problem-solving experts. Paper presented at the AERA-Conference. New Orleans; $L O$.

Hirsch, H. (1987). Explanation-based generalization in a logic programming environment. Proceedings of the 10th IJCAI Conference. Milaan.

Hobus, P.P.M., Schmidt, H.G., Boshuizen, H.P.A. \& Patel, V.L. (1987). Contextual factors in the activation of first hypotheses: Expert-novice differences. Medical Education, 21, 471-476. 
Hobus, P.P.M., Hofstra, M.L. Boshuizen, H.P.A. \& Schmidt, H.G. (1988). De context van de klacht als diagnosticum. Huisarts en Wetenschap, 31, 261-267.

Hodgkin, K. (1978). Towards earlier diagnosis in primary care. Edinburgh: Churchill Livingstóne.

Hofstra, M.L., Hobus, P.P.M., Boshuizen, H.P.A. \& Schmidt, H.G. (1988). De invloed van ervaring op diagnostische prestaties van huisartsen. Huisarts en Wetenschap, 3l, $282-284$.

Hogan, R.M. \& Kintsch, W. (1971). Differential effects on study and text trials on longterm recognition and recall. Journal of Verbal Learning and Verbal Behavior, 10,562567.

Hunter, IM.L. (1962). An exceptional talent for calculative thinking. British Journal of Psychology. 53, 243-258.

Jansweijer, W.H.N., Elshout, J.J. \& Wielinga, B.J. (1985). Het leren van de beginnende probleemoplosser. In: Lodewijcks, J.G.L.C. \& Simons, P.R.J. (Eds.), Zelfstandig leren, bijdragen tot de Onderwijsresearchdagen 1984 . Lisse: Swets \& Zeillinger:

Jansweijer, W.N.H. (1988). PDP: Een benadering vanuit de kunstmatige intelligentie van probleemoplossen en leren door doen in een semantisch rijk domein. Academisch Proefschrift Universiteit van Amsterdam, Amsterdam.

Jong, A.J.M. de (1986). Kennis en het oplossen van vakinhoudelijke problemen. Academisch Proefschrift TUE, Eindhoven.

Jongman, R.W. (1968). Het oog van de meester. Assen: Van Gorcum.

Joseph, G.-M. \& Patel, V.L. (1987). Domain knowledge and medical problem solving: An on-line analysis. (CME87-CS9). Montreal, Quebec, Canada.

Kassirer, J.P., Kuipers, B.J. \& Gorry, G.A. (1982). Toward a theory of clinical expertise. The American Journal of Medicine, 73, 251-259.

Kaufman, D. \& Patel, V.L. (1988). Interactive medical problem solving in the context of a clinical interview: The nature of expertise. In: Proceedings of the 10th Annual Meeting of the Cognitive Science Society. Montreal Canada. Hillsdale, NJ: Erlbaum.

Kintsch, W. (1974). The representation of meaning in memory. Hillsdale, NJ: Erlbaum.

Kintsch, W, \& Greeno, J,G. (1985). Understanding and solving word arithmetic problems. Psychological Review, 92, 109-129.

Kleinsmith, L.J. \& Kaplan, S. (1963). Paired-associate learning as a function of arousal and interpolated interval. Journal of Experimental Psychology, 65, 190-193.

Kơhler, W. (1925). The mentality of apes. New York: Harcourt Brace Jovanovich.

Kuipers, B.J. \& Kassirer, J.P. (1984), Causal reasoning in medicine; Analysis of a protocol Cognitive Science, 8, 363-385.

Kuipers, B.J. (1984). Common-sense reasoning about causality: Deriving behavior from structure, Artificial Intelligence, 24, 169-203.

Laird, J.E., Rosenbloom, P.S. \& Newell, A. (1986). Chunking in SOAR: The anatomy of a general learning mechanism. Machine Learning, $1,11-46$.

Lamberts, H. (1984). Morbidity in general practice; Diagnosis-related information from the monitoring project. Utrecht: Uitgeversmaatschappij Huisartsenpers b.v.

Larkin, J.H., McDermott, J, Simon, D. \& Simon, H.A. (1980). Expert and novice performance in solving physics problems. Science, 208, 1335-1342.

Larkin, J.H. (1983). The role of problem representation in physics. In: Gentner, D. \& Gentner, A.L. (Eds.), Mental Models. Hillsdale, NJ: Erlbaum.

Lave, J., Murtaugh, M. \& De la Roche, 0 . (1984). The dialectics of arithmetic in grocery shopping. In: Rogoff, B. \& Lave, J. (Eds.), Everyday cognition; Its development in social context. Cambridge, MA.: Harvard University Press.

Leinhardt, G. (1987). Situated knowledge: An example from teaching. Paper presented at the AERA-Conference. Washington, DC. 
Lemieux, M. \& Bordage, G. (1986). Structuralisme et pédagogie médicale: Etude comparative des stratégies cognitives d'apprentis-médecins. Recherches Sémiotiques; 6 , 143-179.

Lesgold, A.M. (1984). Acquiring Expertise. In: Anderson, J.R. \& Kosslyn, S.M. (Eds.), Tutorials in learning and memory; Essays in honor of Gordon Bower. San Francisco: Freeman \& Comp.

Lesgold, A.M., Feltovich, P.J., Glaser, R. \& Wang, Y. (1981). The acquisition of perceptual diagnostic skill in radiology. (Technical Report PDS-1). Pittsburg, Penn.

Lindeboom, G.A. (1972). Geschiedenis van de medische wetenschap in Nederland. Bussum: Fibula-Van Dishoek.

Luchins, A.S. (1942). Mechanization in problem solving. Psychological Monographs, Vol. 54.

Maier, N.R.F. (1931), Reasoning in humans: II, The solution of a problem and its appearance in conciousness. Journal of Comparative Psychology, 12, 181-194.

Maier, N.R.F. (1930). Reasoning in humans: I. On direction. Journal of Comparative Psychology, 10, 115-143.

Mayer, R.E. (1983). Thinking, problem solving, cognition. New York: Freeman.

McKeithen, K.B., Reitman, J.S., Rueter, H.H. \& Hirtle, S.C. (1981), Knowledge organization and skill differences in computer programmers. Cognitive Psychology, 13, 307-325.

Messick, S. (1984). The psychology of educational measurement. Journal of Educational Measurement, 21, 215-237.

Meyer, D.E. \& Schvaneveldt, R.W. (1971). Facilitation in recognizing pairs of words: Evidence of a dependence between retrieval operations. Journal of Experimental Psychology, 90, 227-234.

Mitchell, T.M., Keller, R.M. \& Kedar-Cabelli, S.T. (1986). Explanation-based generalization. A unifying view. Machine learning, 1,47-80.

Morris, P.E., Gruneberg, M.M., Sykes, R.N. \& Merrick, A. (1981). Football knowledge and the acquisition of new results. British Journal of Psychology, 72, 479-483.

Müller, G. E. (1911). Zur Analyse der Gedăchtnistătigkeit und des Vorstellungsverlaufes. Zeitschrift für Psychologie, 5.

Muzzin, LJ., Norman, G.R., Feightner, J.W., \& Tugwell, P. (1983). Expertise in recall of clinical protocols in two specialty areas. Proceedings of the 22nd Conference on Research in Medical Education. Washington, DC.

Muzzin, L.J., Norman, G.R., Jacoby, L.L., Feightner, J.W., Tugwell, P. \& Guyatt, G. (1982). Manifestations of expertise in recall of clinical protocols. Proceedings of the 21 st Conference on Research in Medical Education. Washington, DC.

Neisser, U. (1976). Cognition and reality, Principles and implications of cognitive psychology. San Francisco: Freeman.

Newell, A. \& Simon, H.A. (1972). Human problem solving. Englewood Cliffs, NJ: Prentice-Hall,

Norman, D.A. (1978). Notes toward a theory of complex learning. In: Lesgold, A.M., Pellegrino, J.W, Fokkema, S.D. \& Glaser, R. (Eds.), Cognitive psychology and instruction. New York: Plenum.

Norman, G.R., Jacoby, L.L., Feightner, J.W., \& Campbell, E.J.M. (1979). Clinical experience and the structure of memory. Proceedings of the $18 \mathrm{th}$ Annual Conference on Research in Medical Education. Washington, DC.

Norman, G.R., Muzzin, L.J. \& Calva, J. (z.j.). Context and configuration in expert memory of laboratory data. Hamilton, Ontario: McMaster University. 
Norman, G.R., Muzzin, LJ. \& Rosenthal, D. (1985). Expert-novice differences in perception and categorization in dermatology. Paper presented at the AERA-Conference. Chicago, $\mathrm{LL}$.

Norman, G.R., Brooks, L.R., Allen, S.W. \& Rosenthal, D. (1988). Improvement in medical knowledge unrelated to stable knowledge. In: Proceedings of the 10th Annual Meeting of the Cognitive Science Society. Montreal, Canada. Hillsdale, NJ: Erlbaum.

Norman, G.R., Brooks, L.R. \& Allen, S.W. (1987). Recall of experts and novices as a record of processing attention. Paper presented at 26 th Conference on Research into Medical Education. Washington. Washington: RIME.

Norman, G.R. \& Muzzin, L.J. (1989, in druk). Studies of visual perception in medicine. In: Schmidt, H.G., Nooman, Z. \& Exzat, E. (Eds.), Innovation in medical education: An evaluation of its present status. New York: Springer.

Onderwijscommissie Faculteit der Geneeskunde. (1987). Nota de rode draad MI. (BO 8714.273). Maastricht: Rijksuniversiteit Limburg.

Owens, J., Bower, G.H. \& Black, J.B. (1979). The "soap opera" effect in story recall. Memory and Cognition, 7, 185-191.

Patel, V.L., Evans, D.A. \& Groen, G.J. (1988, in druk). Biomedical knowledge and clinical reasoning. In: Evans, D.A. \& Patel, V.L. (Eds.), Cognitive science in medicine. Cambridge, MA: MIT Press.

Patel, V.L. \& Frederiksen, C.H. (1984). Cognitive processes in comprehension and knowledge acquisition by medical students and physicians. In: Schmidt, H.G. \& De Volder, M.L. (Eds.), Tutorials in problem-based learning; A new direction in teaching the health professions. Assen: Van Gorcum.

Patel, V.L. \& Groen, G.J. (1986). Knowledge-based solution strategies in medical reasoning. Cognitive Science, 10, 91-110.

Patel, V.L., Evans, D.A. \& Chawla, A. (1986). Predictive versus diagnostic reasoning in the application of biomedical knowledge. In: Proceedings of the 8ih Annual Conference of the Cognitive Science Society. Hillsdale, NJ: Erlbaum.

Patel, V.L., Frederiksen, C.H. \& Groen, G.J. (1983). Relationship between comprehension and medical problem solving. Conference on Research in Medical Education of $A A M C$. Washington, DC.

Patel, V.L. \& Medley-Mark, V. (1986). Relationship between representation of textual information and underlying problem representation in medicine. (CME Report \# CME86-CS1). Montreal: MeGill University.

Patel, V.L. \& Groen, G.J. (1986). The role of mental models in causal explanations by medical students. Paper presented at the AERA-Conference. San Francisco, CA.

Patel, V.L., Arocha, J.F. \& Groen, G.J. (1986). Strategy selection and degree of expertise in medical reasoning. In: Proceedings of the 8th Annual Conference of the Cognitive Science Society. Hillsdale, NJ: Erlbaum.

Pauker, S.G., Gorry, G.A., Kassirer, J.P. \& Schwartz, W.B. (1976). Towards the simulation of elinical cognition; Taking a present illness by computer. The American Journal of Medicine, 60, 981-996.

Perfetto, G.A., Bransford, J.D. \& Franks, JJ. (1983). Constraints on access in problem solving contexts. Memory and Cognition, 11,24-31.

Piaget, J. \& Inhelder, B. (1973). Memory and intelligence. London: Routledge \& Kegan Paul.

Pichert, J.W. \& Anderson, R.C. (1977). Taking different perspectives on a story. Journal of Educational Psychology, 69, 309-315.

Potts, G. R. (1972). Information processing strategies used in encoding linear orderings. Journal of Verbal Learning and Verbal Behavior, 11, 727-740. 
Rasmussen, J. (1986). Information processing and human-machine interaction; An approach to cognitive engineering. Amsterdam: North-Holland.

Ratcliff, R. \& McKoon, G. (1981). Does activation really spread? Psychological Review, $88,454-462$.

Ridderikhoff, J. (1986). Decision-making strategies in the general practice. Unpublished doctoral dissertation, Erasmus Universiteit, Rotterdam.

Roenker, D.L., Thompson, C.P.\& Brown, S.C. (1971). Comparison of measures for the estimation of clustering in free recall. Psychological Bulletin, 76,45-48.

Rumelhart, D.E. \& Norman, D.A. (1978). Accretion, tuning and restructuring: Three modes of learning. In: Klatzky, R. \& Cotton, J.W. (Eds.), Semantic factors in cognition. Hillsdale, NJ: Erlbaum.

Sacks, O. (1986). The man who mistook his wife for a hat. London: Picador.

Schmidt, H.G. (1982). Activatie van voorkennis, intrinsieke motivatie en de verwerking van tekst, Studies in probleemgestuurd onderwijs. Apeldoorn: Van Walraven.

Schmidt, H.G. (1984). Activatie van voorkennis en tekstverwerking. Nederlands Tijdschrift voor de Psychologie en haar Grensgebieden, 29, 335-347.

Schmidt, H.G., Grave, W.S. de, De Volder, M.L., Moust, J.H.C. \& Patel, V.L. (1989, in druk). Explanatory models in the processing of science text: The role of prior knowledge activation through small-group discussion. Journal of Educational Psychology.

Schmidt, H.G. \& Norman, G.R. (1988). On the development of expertise in medicine: Evidence from case representation studies. Maastricht: Rijksuniversiteit Limburg.

Schmidt, H.G. \& Norman, G.R. (1989). A stage theory on the development of expertise in memory. Paper to be presented at the AERA-Conference. San Francisco, CA.

Schmidt, H.G., Boshuizen, H.P.A. \& Hobus, P.P.M. (1988). Transitory stages in the development of medical expertise: The "intermediate effect" in clinical case representation studies. In: Proceedings of the 10th Annual Conference of the Cognitive Science Society. Montreal, Canada. Hillsdale, NJ: Erlbaum.

Selz, O. (1922). Zur Psychologie des produktiven Denkens und des Irrtums. Bonn.

Shiffrin, R.M. (1975). Short-term store: The basis for a memory system. In: Restle, F., Shiffrin, R. M., Castellan, N.J., Lindman, H., \& Pisoni, D.B. (Eds.), Cognitive theory; Vol. 1. Hillsdale, NJ: Erlbaum.

Shneiderman, B. (1976). Exploratory experiments in programmer behavior. International Journal of Computer and Information Services, 5, 123-143.

Simon, D.P. \& Simon, H.A. (1979), A tale of two protocols. In: Lochhead, J. \& Clement, J. (Eds.), Cognitive process instruction. Philadelphia, PA: The Franklin Institute Press.

Snoek, J.W. (1989, in voorbereiding). Het denken van de neuroloog. Academisch Proefschrift Rijksuniversiteit Groningen, Groningen.

Spilich, G.J., Vesonder, G.T., Chiesi, H.L. \& Voss, J.F. (1979). Text processing of domain-related information for individuals with high and low domain knowledge. Journal of Verbal Learning and Verbal Behavior, 18, 275-290.

Spíro, RJ. (1980). Constructive processes in prose comprehension and recall. In: Spiro, R.J., Bruce, B.C. \& Brewer, W.F. (Eds.), Theoretical issues in reading comprehension; Perspectives from cognitive psychology, linguistics, artificial intelligence and education. Hillsdale, NJ: Erlbaum.

Steels, L. (1985). Tweede generatie expertsystemen. Informatie, 27,966-971.

Sternberg, R.J. (1977). Intelligence, information processing, and analogical reasoning. Hillsdale, NJ: Erlbaum.

Tulving, E. (1972). Episodic and semantic memory. In: Tulving, E. \& Donaldson, W. (Eds.), Organization of memory. New York: Academic Press. 
Voss, J.F., Tyler, S. \& Yengo, L. (1983). Individual differences in the solving of social science problems. In: Dillon, R. \& Schmeck, R. (Eds.), Individual differences in cognition. New York: Academic Press.

Wickelgren, W.A. (1977). Learning and memory. London: Prentice-Hall.

Wundt, W. (1918). Grundriss der Psychologie. Leipzig. 


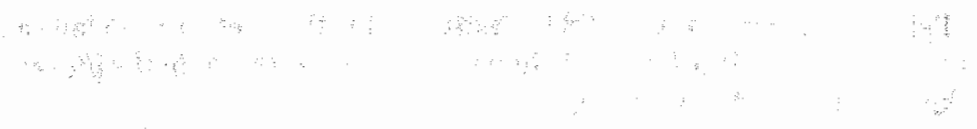




\section{BIJLAGE 1}

\section{GEINSTANTIEERDE ZIEKTESCRIPTS}

\section{alcoholisme}

\section{enabling conditions:}

predisponerende factoren:

$$
\text { psychische problemen }
$$

neurotische depressies

WAO

begremzende factoren:

- leeftijd: 38 jr

fault:

psychische en lichamelijke afhankelijkheid van alcohol

consequences:

- sinds 6 jaar toenemend alcoholgebruik

- Ijaar geleden aanval van pancreatitis

1 jear geleden Refusalkaur

- 1/2 jaar geleden weer begonnen met drinken

- slechre eetliust

onregelmatig cetpatroon

- onvolwaardige voeding

- gewichtsverlies. $5 \mathrm{~kg}$ in een half jaar afgevallen.

enige levendysfunctie:

interminterende icterus

zonder fysisch-diagnostische bevindingen 


\section{enabling conditions:}

predisponerende

factoren:

begrenzende factoren:
* - sinds 6 jaar toenemend alcoholgebruilk

* - 1 jaar geleden aanval van pancreatitis

* - 1/2 jaar geleden weer begonnen met drinken

* suicidepoging twree dagen geledenmet 6 Mogadion en grote hoeveelheden alcohol

- slechte eetlust

- onregelmatig cetpatroon

- onvolwaardige voeding

menu vanmorgen: boterham met een spiegelei met ham

- gewichtsverlies: $5 \mathrm{~kg}$ in een half jaar afgevallen

- leeftijd: 38 jaar

visite om 9 uur "s avonds na telefoontjes

parotis niet opgezet.

fault: toxisch destructie van weefsel ten gevolge van alcoholgebruik

consequences:

lichamelijk

ondetzoek:

* lab:
* continue pijn in de bovenbuik, die uitstraalt naar de rug

vanmorgen begonnen met vage pijn in de bovenbuik sindsdien steeds toegenomen, maar nu constant heftige, borende pijn, die dwars door hem heen gaat kan niet met één vinger aangeven waar de pijn het hevigst is

* zit in een stoel, buigt steeds voorover of trekt de knieën op

pijn werd niet beïnvloed door overgeven

* pijn lijkt op de pijn bij pancreatitis

toen begon het alleen plotseling en was erger

laatste tijd vaker dit soort pijn gehad, maar nooit zo erg als nu

pijn verdween bijna steeds binnen een dag

* ziet er niet ziek uit

maar heeft een van pijn vertrokken gezicht

pijn heeft geen relatie met maaltijden

lichtere en stinkender ontlasting

buik matig opgezet;

matig meebewegend met de ademhaling

verminderde darngenuisen

lever en milt niet opgezet

lichte drukpijn in epigastrio; geen défense;

buik verder niet drukpijnlijk;

verder geen afwijkingen in de buik palpabel

serumamylase verhoogd;

glucose verhoogd (licht)

leuco's verhoogd (licht);

BSE verhoogd(licht);

$\mathrm{Hb}$ normaal

$-=$ items die beide scripts instantiëren 


\section{BIJLAGE 2}

\section{TeKsten VAN DE 4 Casus IN EXPERIMENT 1}

CASUS 1

1. patiënt is een man, van 55 jaar

2. gehuwd, 3 kinderen

3. beroep: chef administratie van een verkooporganisatie

4. type consult: visite, 's morgens, na telefoontje wan echtgenote

5. (voorgeschiedenis)

8 jaar gelden : cardiologisch onderzoek (zonder klachten; vier broers hadden cen hartinfarct): geen af wijkingen

6. (voorgeschiedenis)

$3 / 4$ jaar gelden: $2 \times$ niersteentjes links; spontaan geloosd
CASUS 2

1. patiënt is een man, van 55 jaar

2. gehuwd, 3 kinderen

3. beroep: chef administratie van een verkooporganisatie

4. type consult: op middagspreekuur

5. (voorgeschiedenis)

8 jaar gelden : cardiologisch onderzoek (zonder klachten; vier broers hadden een hartinfarct): geen afwijkingen

6. (voorgeschiedenis) $3 / 4$ jaar gelden: $2 \times$ niersteentjes links; spontaan geloosd 
7. (voorgeschiedenis) enkele maanden geleden: $\mathrm{KNO}$-arts; allergische rhinitis en sinusitis

8. (voorgeschiedenis) enkele maanden geleden: controle IVP na lozen van niersteentjes: geen stenen zichtbaar

9. kdacht: ik heb de hele nacht niet kunnen slapen van de pijn, in de onderbuik

\section{0. (anamnese)}

temperatuur: $38.7^{\circ} \mathrm{C}$ (vnmorgen, rectaal)

\section{1. (anamnese)}

die pijn in de onderbuik is er al enkele dagen

12. (anamnese) waar zit de pijn precies? in de onderbuik en in het gebied van het perineum

\section{3. (anamnese)} aard van de pijn: zeurend, geen koliekpijn

\section{4. (anamnese)}

geen pijn in de zij

\section{5. (anamnese)}

bij zitten meer last van pijn dan bij liggen

\section{6. (anamnese)}

steentjes?

geen steentjes of gruis uitgeplast

\section{7. (anamnese)}

mictie: de laatste dagen moeilijk; komt vooral moeilijk op gang

\section{8. (anamnese)}

pijn bij het plassen, in het perineum en in de onderbuik
7. (voorgeschiedenis) enkele maanden geleden: KNO-arts; allergische rhinitis en sinusitis

8. (voorgeschiedenis) enkele maanden geleden: controle IVP na lozen van niersteentjes: geen stenen zichtbaar

9. klacht: ik heb last van pijn in de onderbuik

10. (anamnese)

temperatuur: $38.7^{\circ} \mathrm{C}$ (vnmorgen, rectaal)

11. (anamnese)

die pijn in de onderbuik is er al enkele dagen

12. (anamnese) waar zit de pijn precies? in de onderbuik en in het gebied van het perineum

\section{3. (anamnese)}

aard van de pijn: zeurend, geen koliekpijn

14. (anamnese) geen pijn in de zij

15. (anamnese) bij zitten meer last van pijn dan bij liggen

16. (anamnese) steentjes? geen steentjes of gruis uitgeplast

17. (anamnese) mictie: de laatste dagen moeilijk; komt vooral moeilijk op gang

18. (anamnese) branderig gevoel bij het plassen 


\section{9. (anamnese)}

moest de laatste dagen vaker plassen

dan gewoonlijk

20. (anamnese)

hoe lang deze moeilijkheden met

plassen?

sinds 2 dagen

21. (anamnese)

nog nooit eerder dit soort

mictieklachten gehad

22. (anamnese)

defaecatie: wat pijnlijk; normaal

gevormde ontlasting

23.(anamnese)

pijn in de onderbuik neemt niet toe bij hoesten of persen

24. (anamnese)

niet gebraakt, niet misselijk

25. (anamnese)

eetlust de laatste tijd: normaal

26. (anamnese)

pijn niet speciaal voor of na de maaltijd

\section{7. (anamnese)}

nog andere klachten? een beetje

verkouden

\section{8. (onderzoek)}

ligt in bed; maakt geen ernstig zieke indruk

\section{9. (onderzoek)}

transpiratie: over het gehele lichaam

30. (onderzoek)

abdomen, inspektie: buik beweegt goed mee met de ademhaling

\section{1. (onderzoek)}

abdomen, auscult: normale darmgeruisen
19. (anamnese)

moest de laatste dagen vaker plassen

dan gewoonlijk

20. (anamnese)

hoe lang deze moeilijkheden met

plassen?

sinds 2 dagen

21, (anamnese)

nog nooit eerder dit soont

mictieklachten gehad

22. (anamnese)

defaecatie: af en toe last van obstipatie

23.(anamnese)

pijn in de onderbuik neemt niet toe bij hoesten of persen

24. (anamnese)

niet gebraakt, niet misselijk

25. (anamnese)

eetlust de laatste tijd: normaal

26. (anamnese)

pijn niet speciaal voor of na de maaltijd

27. (anamnese)

nog andere klachten? een beetje verkouden

28. (onderzoek)

maakt geen emstig zieke indruk

29. (onderzoek)

transpiratie: over het gehele lichaam

30. (onderzoek)

abdomen, inspektie: buik beweegt goed

mee met de ademhaling

31. (onderzoek)

abdomen, auscult.: normale

darmgenuisen 
32. (onderzoek)

abdomen, percussie: blaas niet

vergroot; geen abnormale dempingen

\section{3. (onderzoek)}

abdomen, palpatie: drukpijn in de onderbuik, niet scherp gelokaliseerd; geen défense musculaire

34. (onderzoek) genitalia: geen zwelling van scrotum, of roodheid

\section{5. (onderzoek)}

penis: geen afwijkingen;

meatus externus: opening normaal van grootte, geen afvloed

\section{6. (onderzoek)}

lieskanalen : geen zwelling, niet drukpijnlijk

\section{7. (onderzoek)}

regio lumbalis: geen slagpijn in de nierloges

\section{8. (onderzoek)}

palpatie van de nieren: nieren niet palpabel, niet pijnlijk

\section{9. (onderzoek)}

rectaal toucher: glad rectum slijmvlies, niet vast aan onderlaag

40. (onderzoek) rectaal toucher: prostaat asymmetrisch (rechts) enigszins vergroot

\section{1. (onderzoek)}

rectaal toucher: prostaat rechts zacht aanvoelend; mediane groeve niet goed palpabel

\section{2. (onderzoek)} rectaal toucher: prostaat zeer drukpijnlijk
32. (onderzoek) abdomen, percussie: blaas niet vergroot; geen abnormale dempingen

33. (onderzoek) abdomen, palpatie: drukpijn in de onderbuik, niet scherp gelokaliseerd; geen défense musculaire

34. (onderzoek) genitalia: geen zwelling van scrotum, of roodheid

35. (onderzoek) penis: geen afwijkingen; meatus externus: opening normaal van grootte, geen afvloed

36. (onderzoek)

lieskanalen : geen zwelling, niet drukpijnlijk

37. (onderzoek) regio lumbalis: geen slagpijn in de nierloges

38. (onderzoek) palpatie van de nieren: nieren niet palpabel, niet pijnlijk

\section{9. (onderzoek)}

rectaal toucher: glad rectum slijmvlies, niet vast aan onderlaag; normaal gevormde faeces in rectum

40. (onderzoek) rectaal toucher, prostaat niet vergroot. vast elatisch, mediane groeve palpabel

41. (onderzoek) rectaal toucher: prostaat een beetje drukgevoelig 
43. (onderzoek)

pulm.: vesiculair ademgeruis

\section{4. (onderzoek)}

cor: regulaire hartaktie; geen souffles

\section{5. (onderzoek)}

RR: $145 / 90$

46. (onderzoek)

pols: $104 / \mathrm{min}$. reg. aeq.

47. (lab.)

urine na voorzichtig

prostaatexprimering:

vol leucocyten

\section{CASUS 3}

1. man, gehuwd, 38 jaar, 2 kinderen

2. beroep: gasfitter

WAO (wegens psychische problemen) sinds 4 jaar; doet wel eens wat klussen, ook voor zijn vroegere baas

3. (voorgeschiedenis) sinds 24-jarige leeftijd terugkerende neurotische depressies 3 maanden opgenomen geweest in een psychiatrische inrichting sindsdien ambulante psychiatrische begeleiding (GGZ)

4. (voorgeschiedlenis) sinds 6 jaar toenemend al coholgebruik

5. (voorgeschiedenis)

1 jaar geleden ziekenhuisopname wegens pancreatitis acuta
42. (onderzoek)

pulm. auscult: enkele crepiterende rhonchi links postero basaal

43. pulm. percussie: longgrenzen beiderzijds matig bewegend

44. (onderzoek) cor: regulaire hartaktie; geen souffles

45. (onderzoek)

RR: $145 / 90$

46. (onderzoek) pols: 104/min reg. aeq.

47. (lab.) urine na rectaal toucher: 10 a 12 leuco's per gezichtsveld

\section{CASUS 4}

1. man, gehuwd, 38 jaar, 2 kinderen

2. beroep: gasfitter WAO (wegens psychische problemen) sinds 4 jaar; doet wel eens wat klussen, ook voor zijn vroegere baas

3. (voorgeschiedenis) sinds 24-jarige leeftijd terugkerende neurotische depressies 3 maanden opgenomen geweest in een psychiatrische inrichting sindsdien ambulante psychiatrische begeleiding (GGZ)

4. (voorgeschiedenis) sinds 6 jaar toenemend alcoholgebruik

5. (voorgeschiedenis) 1 jaar geleden ziekenhuisopname wegens ulcus ventriculi; conservatief behandeld 
6. (voorgeschiedenis)

1 jaar geleden eenmalige Refusalkuur gehad

7. type consult: huisbezoek, $s$ avonds om 9 uur

8. klacht" continue pijn in de bovenbuik die doortrekt naar de rug

9. (anamnese)

"s morgens begonnen met vage pijn in de bovenbuik

10. (anamnese)

pijn is sindsdien steeds toegenomen, is nu constant.

11. (anamnese) het is een heftige, borende pijn die dwars door hem heen gaat

12. (anamnese)

hij kan niet met een vinger aangeven waar de pijn het hevigst is

13. (onderzoek) houding: de patiènt zit in een stoel, waarbij hij steeds vooroverbuigt of de benen optrekt; beweegt zich verder normal

\section{4. (anamnese)}

hij heeft net overgegeven; dit had geen invloed op de pijn

\section{5. (anamnese)}

de pijn lijkt wel op de pijn waarvoor hij verleden jaar is opgenomen geweest, maar toen begon het heel plotseling; het was bovendien erger

\section{6. (anamnese)}

hij heeft de laatste tijd we vaker dit soort pijn die doortrekt naar de nug gehad, maar nooit zo sterk als nu
6. (voorgeschiedenis)

1 jaar geleden eenmalige Refusalkuur gehad

7. (voorgeschiedenis) rookt een pakje sigaretten per dag

8. type consult: spreekuur

9. klacht: continue pijn in de bovenbuik

10.(anamnese)

's morgens begonnen met een drukkend gevoel in de bovenbuik

11. (anamnese) pijn is sindsdien steeds toegenomen, is nu constant

12. (anamnese) het is een doffen continue pijn, die niet uitstraal

\section{3. (anamnese)}

hij kan niet met een vinger aangeven waar de pijn het hevigst is

14. (onderzoek)

houding: de patiernt loopt en zit wat voorovergebogen; beweegt zich verder normaal

\section{4. (anamnese)}

hij heeft vanochtend na het ontbijt overgegeven; dit had geen invloed op de pijn

\section{6. (anamnese)}

de pijn lijkt wel op de pijn waarvoor hij verleden jaar is opgenomen geweest, maar nu is het minder scherp gelokaliseerd; nu is het bovendien erger

\section{7. (anamnese)}

hij heeft de laatste tijd we vaker dit soort pijn gehad, maar nooit zo sterk als nu 


\section{7. (anamnese)}

meestal was die binnen een dag vanzelf weer verdwenen

18. (anamnese)

hij heeft aspirientjes geprobeerd; die hadden geen effekt

19. (anamnese)

alcoholgebruik: drinkt sinds een half jaar weer

drinkt weer net zo veel als vroeger

20. (anamnese)

drepressies: hij zat de laatste $11 / 2$ week weer flink in de put

hij heeft 2 dagen geleden geprobeerd overal een eind aan te maken door 6 tabletten Mogadon met flink veel alcoholica in te nemen

21. (onderzoek) uiterlijk: ziet er niet ziek uit, maar heeft een van pijn vertrokken gezicht

22. (onderzoek) uiterlijk: niet anemisch, niet icterisch3

23. (anamnese) heeft volgens anderen de afgelopen tijd wel af en toe geel gezien

\section{4. (anamnese)}

cetlust: slecht

25. (anamnese)

eetpatroon; onregelmatig

26. (anamnese) eetgewoonten: eet vaak patat met een slaatje, een frikandel of een gehaktbal

\section{7. (anamnese)}

menu vandaag: hij heeft ontbeten met een boterham met een spiegelei en ham gisteravond: spaghetti met tomatensaus
18. (anamnese)

meestal was die binnen een dag vanzelf weer verdwenen

19. (anamnese)

hij heeft aspirientjes geprobeerd, die hadden geen effekt

20. (anamnese)

alcoholgebruik: drinkt sinds een half jaar weer

drinkt weer net zo veel als vroeger

22. (anamnese)

drepressies: hij zat de laatste 11/2 week weer flink in de put

hij heeft 3 dagen geleden geprobeerd overal een eind aan te maken door 6 tabletten Mogadon met flink veel alcoholica in te nemen

22. (onderzoek) uiterlijk: ziet er niet ziek uit, maar wekt wel de indruk pijn te hebben

23. (onderzoek) viterlijk: niet anemisch, niet icterisch

24. (anamnese) heeft volgens anderen de afgelopen tijd well af en toe geel gezien

25. (anamnese) eetlust: slecht

26. (anamnese) eetpatroon: onregelmatig

27. (anamnese) eetgewoonten: eet vaak patat met een slaatje, een frikandel of een gehaktbal

28. (anamnese) menu vandaag: hij heeft ontbeten met een beschuit en een beker melk en een eitje gisteravond: spaghetti met tomatensaus 
28. (anamnese)

pijnklachten hebben geen relatie met maaltijden

29. (anamnese)

gewicht: het laatste $1 / 2$ jaar $\pm 5 \mathrm{~kg}$

afgewallen

30. (anamnese)

ontlasting: geen problemen mee, geen

veranderd defaecatiepatioon

31. (anamnese)

ontlasting: is volgens de patient laatste tijd lichter van kleur en stinkt meer

32. (anamnese)

ontlasting: gisteren voor het laatst

ontlasting gehad

\section{3. (anamnese)}

temperatuur: om 6 uur vanavond $37.8^{\circ} \mathrm{C}$

34. (onderzoek)

pols: regelmatig, $72 / \mathrm{min}$

\section{5. (onderzoek)}

RR: $140 / 95$

36. (onderzoek)

ademhaling: $18 / \mathrm{min}$

\section{7. (onderzoek)}

abdomen, inspektie: matig opgezet, matig meebewegend met de ademhaling

\section{8. (onderzoek)}

abdomen, auscult: verminderde darmgeruisen

39. (onderzoek) abdomen, perc:- lever en milt niet vergroot
29. (anamnese)

pijnklachten hebben geen relatie met maaltijden

30. (anamnese) gewicht: het laatste $1 / 2$ jaar $\pm 5 \mathrm{~kg}$ afgevallen

31. (anamnese) ontlasting: geen problemen mee, geen veranderd defaecatiepatroon

31. (anamnese) ontlasting: is volgens de patient laatste tijd lichter van kleur

32. (anamnese) ontlasting: gisteren voor het laatst ontlasting gehad

34. (onderzoek)

polls: regelmatig, $72 / \mathrm{min}$

35. (onderzoek)

RR: $140 / 95$

36. (onderzoek) ademhaling: $18 / \mathrm{min}$

37. (onderzoek) temperatuur: $37.8^{\circ} \mathrm{C}$

38. (onderzoek) abdomen, inspektie: matig opgezet, normaal meebewegend met de ademhaling

39. (onderzoek) abdomen, auscult.: normale darmgeruisen

40. (onderzoek) abdomen, perc.: lever en milt niet vergroot 
40. (onderzoek) abdomen, palpatie: lichte drukpijn in epigastrio; geen défense; buik verder niet drukpijnlijk; verder geen afwijkingen in de buik palpabel

41. (onderzoek) cor: percutoir niet vergroot; normale tonen; regulair ritme; geen geruisen

\section{2. (onderzoek)}

pulm.: normaal beweeglijke grenzen beiderzijds; normaal ademgenuis

\section{3. (onderzoek)}

aa. femorales, palp.: pulseren

beiderzijds goed

ausc.: geen abnormale vaatgeruisen

\section{4. (onderzoek)}

rectaal toucher: geen afwijkingen

\section{5. (onderzoek)}

veneuze druk niet verhoogd

46. (onderzoek) parotis: beiderzijds niet opgezet

\section{7. (anamnese)}

verder geen klachten

48. labgegevens:

serumamylase: $128 \mathrm{E}$

(normaal 8-16)

glucose: $6.0 \mathrm{mmol} / \mathrm{h}$

(normaal 4.4-5.8)

leucocyten: $11.0 \times 10^{9} / 1$

(normaal $5-10 \times 10^{9}$ )

BSE: $15 \mathrm{~mm}$ na 1 uur (normaal -10)

Hb: $9.0 \mathrm{mmol} / 1$

(normaal 8.8-11.2)
41. (onderzoek)

abdomen, palpatie: drukpijn in epigastrio; geen défense; buik verder niet drukpijnlijk; verder geen afwijkingen in de buik palpabel

42. (onderzoek)

cor: percutoir niet vergroot, normale tonen; regulair ritme; geen geruisen

43. (onderzoek)

pulm.: normaal beweeglijke grenzen beiderzijds; normaal ademgeruis

44. (onderzoek)

aa. femorales, palp.: pulseren

beiderzijds goed

ausc.: geen abnormale vaatgeruisen

45. (onderzoek)

rectaal toucher: geen afwijkingen

46. (onderzoek)

veneuze druk niet verhoogd

47. (anamnese)

verder geen klachten

48. labgegevens:

serumamylase: $32 \mathrm{E}$

(normaal 8-16)

glucose: $6.0 \mathrm{mmol} / \mathrm{h}$

(normaal 4.4-5.8)

leucocyten: $11.0 \times 10^{9} / 1$

(normaal $5-10 \times 10^{9}$ )

BSE: $15 \mathrm{~mm}$ na 1 uur

(normaal -10)

Hb: $7.8 \mathrm{mmol} / \mathrm{h}$

(normaal 8.8-11.2) 
$\therefore a_{0}+a-4$

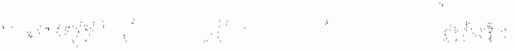

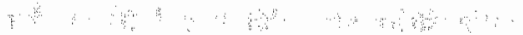

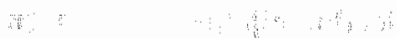

$\therefore \quad$ \&

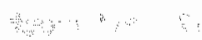

से क्ष

के ने का

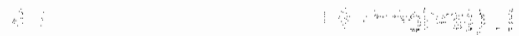

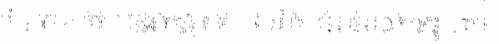

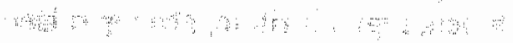

$\because$ aो क्ष

कम

$\because \%$ \%

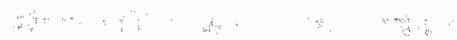

-

औas

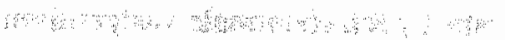

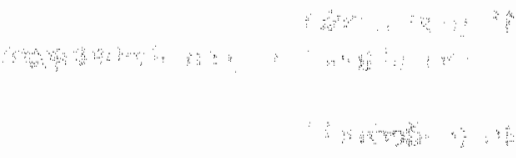

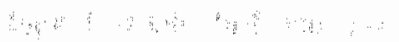

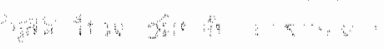

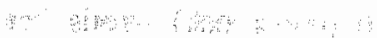

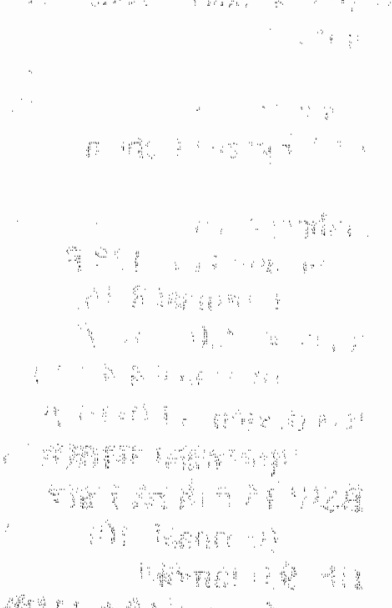

$$
\begin{aligned}
& \text { an } \\
& \text { a }
\end{aligned}
$$

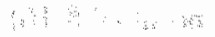

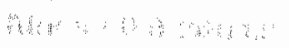

$$
\begin{aligned}
& \text { औल }
\end{aligned}
$$

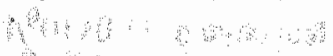

$$
\begin{aligned}
& \text { का का - का क्य } \\
& \text { औn } \\
& \text { और "म का }
\end{aligned}
$$

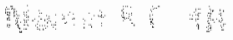

$$
\begin{aligned}
& \text { औrmpl }
\end{aligned}
$$

\footnotetext{
औ
} 


\section{BIJLAGE 3}

\section{VIER RECALLPROTOCOLLEN VAN DE TYPISCHE PROSTATITIS CASUS}

free recall protocol van pp \# $2-3$

aantal units 21

- prostaat is drukpijnlijk ।

- mediale groeve niet palpabel

- rectaal toucher slijmvlies glad I

- geen steengruis bij plassen !

- geen slagpijn nierloges I

- cor. normaal; I geen souffles I

- pneu: vesiculair ademgeruis !

- onderzoek: niet precies gelokaliseerde pijn in onderbuik I

- onderzoek: genitalien I + lieskanaal bij palpatie niet pijnlijk |

- patient is 55 jaar I gehuwd / 3 zonen (?) ।

- heeft 4 broers die cen hartinfarct gehad hebben I

- bij KNO-arts geweest; allergische rhinitis I sinusitis I

- temp 38,7 I

- patiěnt ligt op bed I ziet niet erg ziek uit I transpireert hevig |

- auscultatie colon: normaal darmgeruis | 
Man, I 55 jaar, I gehuwd, 3 kinderen I

Yoorgeschiedenis

$8 \mathrm{jr}$ geleden cardiologisch onderzoek (geen klachten, 4 broers overleden aan hartinfarct):

geen afwijkingen I

$3 / 4 \mathrm{jr}$ geleden:

$2 \times$ niersteentjes links verdwenen na urinelozing I

Poosje geleden: controle IVP, geen niersteentjes aanwezig I

Siluatie: visite, opgebelt ('s morgens) door echtgenote

Klacht: man heeft pijn in de onderbuik I en in het gebied rondom het perineum I Zeurende pijn, I geen koliekpijn I

Mictie: geen steentjes of gruis uitgeplast I had pijn bij het plassen, I moest vaker plassen dan normaal |

Transpiratie: gedurende de hele nacht I

Had geen last van misselijkheid I en had niet overgegeven I

Hij had pijn bij zitten $\rightarrow>$ minder bij liggen

Geen pijn in de zij I

Defecatie: pijnlijk, geen verandering worm |

Mictie: urine was niet rood I

Qnderzoek: man لigt op bed,I maakt geen zileke indruk I

pols $104 / \mathrm{min}$. reg. aeq. I

RR 145/90 ||

temp: $38.7^{\circ} \mathrm{C}$ (vanmorgen rectaal) I

abd.: insp. niet opgezet, I normaal meebewegen

(ademhaling) I

ausc.: normale darmgenuisen I

perc:: geen dempingen, $\mathrm{g} . \mathrm{b} . \mathrm{I}$

palp.: niet drukpijnlijk, g.b. 1

RT 1. glad rectumslijmvlies, geen afw. I

2. prostaat vergroot | (asymmetrisch rechts) | mediane groeve niet te palperen 1

scrotum: niet vergroot, geen roodheid

penis: $g$. afw.

urethra: g.a., I ronde opening I

liezen: geen drukpijn, I niet gezwollen I

pulm. : vesiculair ademgeruis ।

cor: geen geruisen, I souffles I

lab: na prostaatexprimatie: urine vol leuco's

Beroep: chef administratie van een middelgrote firma I

Meneer is verkouden I

Eetlust: normaal I

Pijn neemt niet toe/af na <--> voor maaltijd I

Geen toename pijn bij hoesten/persen I

Man had 2 dagen al pi.jn, I zeurend I 
- man $155 \mathrm{j}$ oud I getrouwd I 2 kinderen I

- vroeger nierstenen gehad

- deze heeft hij spontaan uitgeplast I

- IVP daarna normaal I

- pijn in de onderbuik I sinds 2 dagen I continu I

- pijn bij zitten I

- geen koliekpijn I

- bij lichamelijk ondz.

$-t 38.7$ |

veel leuco's in de urine I

drukpijn in de onderbuik ।

bij rectaal toucher

- pijn aan het perineum I

- de ontlasting was normaal I

- bij KNO-arts geweest i.v.m. allergische rhinitis I

- de pijn wordt niet erger bij hoesten/persen I

- geen liesbreuk te zien I

- nieren niet pijnlijk bij palpatie I

- geen slagpijn in de nierloges I

- bij rectaal toucher
- pijn bij plassen I

- moeite om te plassen 1

- pijn bij defecatie । vergrote | pijnlijke prostaat | die naar rechts groter is en I zachter dan normaal ! geen aambeien 1

gladde wand I

los van de onderlaag 1

\section{free recall protocol van $\mathrm{pp}$ \# A-11}

aantal units 38

Man I 55 jaar I chef verkoopafdeling I 3 kinderen I

Vrouw belt 's morgens voor visite I

8 jaar geleden cardiologisch onderzoek geen afwijkingen

4 broers overlden aan hartinfarct 1

$1 / 2$ jaar geleden $2 \times$ niersteentje spontaan geloosd I

3 maanden geleden rhinitis vasomotorica I sinusitis KNOarts I

$1 / 2$ jaar geleden IVP g.a.I

Vannacht niet geslapen onderbuikspijn I ter hoogte van het perineum I

Sinds 2 dagen klachten I ligt in bed ||

Meer pijn bij zitten dan liggen I

Plast wat vaker I plassen doet pijn | beginnen met plassen doet pijn I

Geen kolieken I ontlasting doet ook pijn ||

Pijn bij hoesten en persen I

Is ook wat verkouden I

Deze pijn nooit eerder gehad |

Onderzoek: abdomen

$$
\text { RR 145/90 । pols } 104 \mathrm{reg} \text { aeq | T } 38.7^{\circ} \mathrm{C} \text { । }
$$

blaas niet vergroot $I$

genitalia externa penis g.a. I

scrotum

niet rood 1 


$$
\begin{aligned}
& \text { RT: } \begin{array}{l}
\text { niet gezwollen || } \\
\text { huid los van onderlaag | } \\
\text { prostaat Re vergroot.| } \\
\text { sulcus n.p. | } \\
\text { extreem pijnlijk | }
\end{array} \\
& \text { cor: zuivere tonen I } \\
& \text { pulm.: VAG | }
\end{aligned}
$$

Urine na massage beginstroom vol leuco's I 


\section{BIJLAGE 4}

\section{GEANALYSEERD HARDOP-DENK PROTOCOL}

\section{pp \#4-14}

1. man, gehuwd, 38 jaar, 2 kinderen

2. beroep: gasfitter

WAO (wegens psychische pro-blemen) sinds 4 jaar, doet wel eens wat klussen, ook voor zijn vroegere baas

\section{3.(voorgeschiedenis)} sinds 24-jarige leeftijd terugkerende neurotische depressies 3 maanden opgenomen geweest in een psychiatrische inrichting sindsdien ambulante psychiatrische begeleiding (GGZ)

\section{4.(voorgeschiedenis)} sinds 6 jaar toenemend alcohol-gebruik

5. (voorgeschiedenis)

1 jaar geleden ziekenhuisopname wegens pancreatitis acuta

5. $1 \mathrm{jr}$ geleden pancreatitis acuta $\rightarrow$ alcohol ik weet niet precies wat een gasfitter is, dat lijkt me een ... soort loodgieter maar dan op gasgebied 1

en hij heeft nu psychische problemen .. of sinds 4 jaar dat die psychische problemen ... als je in de handen van een psychiater valt dan kom je nooit meer eh weer goed

ehm vind ik niet vreemd

.. dan kan volgens mij heel goed met alcohol sament. 
6.(voorgeschiedenis)

1 jaar geleden eenmalige Refusal-kuur

gehad

7. type consult: huisbezoek, 's avonds om 9 uur ik neem aan dat dat een ontwenningskuur ist

enigszins redelijke tijo

7. huisbezoek 21,00 uur

$\mathrm{F} \rightarrow \mathrm{t}$

$\rightarrow$ enigszins redelijke tijd

8.klacht: continue pijn in de boven-buik die doortrekt naar de rug
..... nou daar kan ik me .. alles bij voorstellen .A een pijn daar miet gelokaliseerd is, ... $\mathrm{bij}$ neurotische mensen kun je ook wel eens hebben dat ze bellen terwijl eigenlijk de echte pijn, gewoon om een andere hulpvraag, ... kan hart, \longen, \myocard zijn, \lever \. misschien zelfs de nieren \. maag/darm \.. een heleboe凡

8. continue pijn in de bovenbuik die doortrekt naar de rug

$\&$ neurotisch mens

$\rightarrow$ kan om een heel andere hulpuraag gaan

$->$ ol [echte pijn

$\rightarrow$ hart

$\rightarrow$ longen

$\rightarrow$ myocard

$\rightarrow$ lever

$\rightarrow$ nieren

$\rightarrow$ maag/darm

$\rightarrow$ een hele boel]

$\mathrm{FF}->\mathrm{H} 9[\mathrm{HB} \rightarrow \mathrm{H} 5 \mathrm{H} 8 \mathrm{H} 5 \mathrm{H} 1 \mathrm{H} 8 \mathrm{H} 4 \mathrm{H} 8]$

9.(anamnese)

's morgens begonnen met vage pijn in

de bovenbuik

10. (anamnese)

pijn is sindsdien steeds toegenomen, is nu constant

aha, er wordt me nou verteld wat voor pijn het is!

11. (anamnese) het is een heftige, borende pijn die ... leukl dwars door hem heen gaat 
12. (anamnese)

hij kan niet met een vinger aangeven waar de pijn het hevigst is dus een wat meer gespreide piin :.... meer gespreide pijn, ....ddenk ik meteen weer aan ontstekingsproces dat verder is gegaan of eh . mag/duodenumulcus wat geperforeerd ist

12. kan niet met 6én vinger aangeven waar de pijn het hevigst is $\rightarrow$ meer gespreide pijn

$\rightarrow$ ontstekingsproces dat verder is gegaan

$\mathrm{F}-\rightarrow \mathrm{t}-\rightarrow \mathrm{H} 7 \mathrm{H} 4$

$\rightarrow->$ of maag/duodenum ulcus dat geperforeerd is

13. houding: de patient zit in een stoel, waarbij hij steeds vooroverbuigt of de benen optrekt; beweegt zich verder normaal
... aha, wat doe je nou als je vooroverbuigt \. dat geeft juist meer druk op de maaginhoud of de buikinhoud ...t (en benen optrekt )...... vreemd ....

13. houding voorovergebogen en met opgetrokken benen

$$
\mathrm{F} \rightarrow \mathrm{H} 7
$$

14. (anamnese)

hij heeft net overgegeven; dit had geen invloed op de pijn
->?????? meer druk op maaginhoud of buikwand

.. ja overgeven dat kun je bij alles doen ... lichamelijk $\backslash$ dan wel geestelijk, 1. (had geen invloed op de pijn .......) bij een maagulcus zou ik verwachten dat braken .. dus verwijderen van onder andere zure maaginhoud om 2 uur's avonds \. kan best een zure maaginhoud zijn $\backslash$.. zou dat wel verlichting kunnen geven $\backslash$. tenzij natuurlijke een perforatie .. een perforatie ((onverstaanbaar) als je dan juist wat spul naar buiten in de vrilie buikholte hebr geperst

14. heeft overgegeven, had geen invloed op de piln maagulcus

8 braken

$->$ [venwijdering zure maaginhoud $<-21.00$ uur]

$\&$ geperforeerd ulcus

$\rightarrow$ verlichting

$\mathrm{H} 4 \mathrm{~F}-->[\mathrm{Hb} 7<-\mathrm{F}]-->\mathrm{F}$

$\rightarrow$ (cau) spul naar buiten persen in vrije buikholte

$\mathrm{FH} 7 \rightarrow \mathrm{Hb} 7$ 


\section{5. (anamnese)}

de pijn lijkt wel op de pijn waarvoor hij verleden jaar is opgenomen geweest, maar toen begon het heel plotseling; het was bovendien erger

\section{6. (anamnese)}

hij heeft de laatste tijd we vaker dit soort pijn die doortrekt naar de rug gehad, maar nooit zo sterk als nu

17. (anamnese)

meestal was die binnen een dag vanzelf weer verdwenen

18. (anamnese) hij heeft aspirientjes geprobeerd; die hadden geen effekt hé opname? $\backslash$. in een psychiatrusche kliniek ..((terug zoeken)) \. 1 jaar geleden eenmalige refusalkuur, $L .1$ jaar geleden wegens pancreatitis acuta $\backslash .$. nou ja, pancreatitis \. pijn lijkt wel op de pijn verleden jaar is opgenomenl
.. vraag .. zuipt nog steeds zo veel? \. of zuipt ie weer nadat hij de Refusalkuur gehad?

.. als je drinkt wordt de maag geïrniteerd! en acetylsalicyl is ook niet goed daarvoon

18. aspirienes geprobeerd; hadden geen effekt drinken $\rightarrow$ intatie maag

$\mathrm{F}-\rightarrow \mathrm{H} 4<-\mathrm{F}$ $<-$ acetyl salicyl

19. (anamnese)

alcoholgebruik; drinkt sinds een half jaar weer

drinkt weer net zo veel als vroeger

20. (anamnese)

drepressies: hij zat de laatste $11 / 2$ week weer flink in de put hij heeft 2 dagen geleden gepro-beerd overal een eind aan te maken door 6 tabletten Mogadon met flink veel alcoholica in te nemen
... zou ook niet de eerste zijn

\begin{abstract}
.. zo lukt hem dat natuurliik nooit. met 6 tabletjes Mogadon \. maar goed dan zit je wel iemand die eh ... ja serieuze depressie heeft gehad en nou weer .. en flink zuipt, L..... ik zit aan 2 dingen te denken \. (2 dagen geleden geprobeerd eh suicide te plegen) dan kan hil on dit moment werkeliike piinklachten hebben, \dat zou kunnen door het vele drinken $\downarrow$. (hij drinkt alweer een half jaar), het kan ook zijn dat die piin gefingeend is en hulp vraagt aan de artsh
\end{abstract}

20. $2 \mathrm{dg}$ geleden geprobeerd overal een einde aan te maken door 6 tabletten mogadon met flink veel alcoholica in te nemen

$\rightarrow$ dat lukt natuurlijk nooit

$\rightarrow$ [werkelijke pijnklachten op dit moment <--(cau) vole drinken sinds weer een half jaar]

$\rightarrow->$ of pijn gefingeord en hulp vraagt 


\section{1. (onderzoek)}

uiterlijk: ziet er niet ziek uit, maar heeft een van pijn vertrokken gezicht
... nou dat zegt me geen donder, thet kan daamet het zelfde geweest, $\backslash$ als hij nou wel erg ziek had vitgezien ... zou er aanleiding zijn dat het iets lichameliiks is .... nou . ik kan niks uitschakelen!

21. ziet er niet ziek uit maar, heeft een van pijn vertrokken gezicht

[als ziek uitzien

$\rightarrow$ iets lichamelliks]

$$
\text { <-ziet er niet ziek uit. }
$$

$\rightarrow ? ? ? ? ? ? ? ? ? ?$

$$
\underset{F \rightarrow H<-F}{F \rightarrow H}
$$

22. (onderzoek)

uiterlijk: niet anemisch, niet icte-risch
(.. niet anemisch, .. dan zou je denken hij eet nog normaal $\backslash$. eh (niet icterisch) .. icterisch .. zijn lever betrokkenheid,, .. is in ieder geval nog niets aan de hand

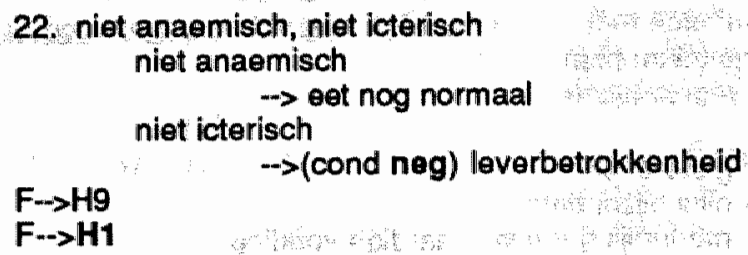

\section{3. (anamnese)} heeft volgens anderen de afgelopen tijd wel af en toe geel gezien
.. aha, ... zou kunnen betekenen dat er eh . ja wat is de afgelopen tijd .. kan dus een betrokkenheid van de lever zijn geweest, ᄂ. ik zou er toch wel aandacht aan besteden bij het lichamelijk onderzoek

23. volgens anderen de afgelopen tijd wel af en toe geel geweest $\rightarrow$ betrokkenheid van de lever $\mathrm{F} \rightarrow \mathrm{H} 1$

24. (anamnese) eetlust: slecht natuurlijk, die meneer krijgt al zijn calorieen binnen via zijn drankt

24. eetlust slecht

$F<-F$

<-krijgt alle calorieên binnen via de drank 
25. (anamnese)

eetpatroon: onregelmatig

26. (anamnese)

eetgewoonten: eet vaak patat met een slaatje, een frikandel of een gehaktbal dat is ook wel hetgeen wat te verwachten wast

... zoiets komt me ook niet onbekend voor L. als je yeel alcohol gebruikt, dan denk ik aan vet eten, X. een soort bescherming van de maag wel cens, alcoholopname tussen cen maagwand die met vet besmeerd is $\backslash$.. maar is njet direkt het meest gezonde $\backslash$. maar wel lekkert

26. eet vaak patat met een slaatje etc

<-veel alcoholgebruik

$\rightarrow$ vet etten

- > [soort bescherming van de maag;

<- maagwand met vet besmeerd]

->niet direkt het meest gezonde

$\rightarrow$ wel lekker

$\mathrm{F}<-\mathrm{F} \rightarrow \mathrm{H} 7 \rightarrow[\mathrm{Hb4}, \mathrm{Hb}]$

$F \rightarrow t$

$\mathrm{F} \rightarrow \mathrm{t}$

27. (anamnese)

menu vandaag: hij heeft ontbeten met een boterham met een spiegelei en ham gisteravond: spaghetti met tomatensaus
..... ehm niks bijzonders $\backslash .$. wel .... natuurlijk niet volwaardige voeding

27. menu ontbijt en gisteravond

$\rightarrow$ niks bijzonders

$F \rightarrow t$

$\rightarrow$ natuurlijk geen volwaardige voeding

$F \rightarrow t$

28. (anamnese)

pijnklachten hebben geen relatie met maaltijden

29. laatste ..

29. (anamnese)

gewicht: het laatste $1 / 2$ jaar $\pm 5 \mathrm{~kg}$ afgevallen dan vraag ik me af wat hij heeft gegeten om 9 uur 's avonds $\backslash . . .$. ((terugbladeren)) hij heeft blijkbaar niet veel gegeten (eetlust slecht) (pijnklachten geen relatie met de maaltijden )... dat zegt niet zo veel .. eh ..) ja zegt me eigenlijk wel, $\backslash$ misschien wel een duidelijke aanwijzing maar niet iets waar ik nou direkt mee verder kanl

... nou ehm .. slechte voedingt

29. laatste $1 / 2$ jaar $\pm 5 \mathrm{~kg}$ afgevallen 
30. (anamnese)

ontlasting: geen problemen mee, geen veranderd defaecatiepatroon
.... ja vind ik eigenlijk wel vreemd.. aan de ene kant ... zegt hij dat hij (slechte eetlust heeft dan zou je dus ondervulling kunnen kriigen van de darm naar obstipatiel... en en hetgeen wat hij eet eh van . die twee maaltijden .. aan de andere mate redellijk vet... en koolhydraten .. voornamelijk \ daar bliift ook niet ze veel van zitten, \dus ik had eigenlijk wel verwacht dat hij .. geen ... een ongezond. defecatiepatroon L.. (ja hij heeft er geen problemen mee) $\backslash$.. (is niet veranderd), $\backslash \mathbf{i k}$ zou willen weten hoe is het geweest $\backslash$. .. hard,.. daar komt het

30. ontlasting geen problemen mee, geen veranderd defecatiepatroon slechte eetlust

$\rightarrow$ (zOU) ondervulling

$\rightarrow$ obstipatie

menu vandaag en gisteren

-> redelijk vet en koolhydraten

$\rightarrow$ blijt weinig van zitten

$\mathrm{F} \rightarrow \mathrm{Hb} 7-\rightarrow \mathrm{H} 7$

$\rightarrow$ (zou) ongezond defgecatiepatroon

$\mathrm{F}->\mathrm{Hb} 7 \rightarrow \mathrm{H} \mathrm{Hb7}->\mathrm{F}$

31. (anamnese)

ontlasting: is volgens de patiênt laatste tijd lichter van kleur en stinkt meer
(.. lichter van kleur en stinkt meer) \. zou kunnen betekenen ... ehm ... geen gal meer. erbiji dat zou ook zjjn maag kunnen verklaren, $\backslash z$ 'n vetafbraak niet volledig, \(lichter van kleur .. stinkt meer 入.. dus hij stinkt misschien \. eventueel teveel koolhydraten \... wel interessant dit

31. ontlasting lichter van kleur on meer stinken

$\rightarrow$ geen gal meer

$\rightarrow$ maag

stinken

<-vetafbraak niet volledig

$\mathrm{F} \rightarrow \mathrm{Hb} 2->\mathrm{H} 4<--\mathrm{Hb} 7$

$\mathrm{F} \rightarrow \mathrm{Hb} 7$ 
32. (anamnese) ontlasting: gisteren voor het laatst ontlasting gehad

33. (anamnese) temperatuur: om 6 uur vanavond $37.8^{\circ} \mathrm{C}$

33. $\mathrm{T} 37.8^{\circ} \mathrm{C}$

$$
\begin{aligned}
& \rightarrow \text { normalle temperatuur } \\
& \rightarrow \text { beetje aan de hoge kant }
\end{aligned}
$$

$F \rightarrow$ :

$F \rightarrow t$

34. (onderzoek) pols: regelmatig, $72 / \mathrm{min}$

34. pols $72 / \mathrm{min}$ $\rightarrow$ kan normaal zijn kun je als normale temperatuur beschouwen, $\mathrm{L}$.... neigt een beetie naar de hoge kant

wat was zijn temperatuur? $\$ ben $\mathbf{i k}$ vergeten valt me nu op $38 . \lambda$

$72 /$ min kan normaal zijn

35. (onderzoek)

RR: $140 / 95$

is wat aan de hoge kant die 95

35. tensie 140/95

$\mathrm{F} \rightarrow \mathrm{t}$

95 - >aan de hoge kant

36. (onderzoek)

ademhaling: $18 / \mathrm{min}$

tikje aan de hoge kann

36. ademhaling $18 / \mathrm{min}$

$F \rightarrow t$

$\rightarrow$ tikje aan de hoge kant

37. (onderzoek)

abdomen, inspektie: matig opgezet,

matig meebewegend met de ademhaling

38. (onderzoek)

abdomen, auscult.: verminderde darmgeruisen

zegt ook niet allesi

(-. ja pijnklachten), (verminderde darmgeruisen) ... peritoneale prikkeling, ik heb alleen nog inspektie gedaan met het abdomen \... eh (matig meebewegend met de ademhaling) (.. zou kunnen zijn \

38. verminderde darmgeruisen

\& pijnklachten

$\rightarrow$ peritoneale prikkeling

$\rightarrow$ matig meebewegen met de ademhaling 
39. (onderzoek)

abdomen, perc.: lever en milt niet vergroot
40. (onderzoek)

abdomen, palpatie: lichte drukpijn in epigastrio; geen défense; buik verder niet drukpijnlijk; verder geen afwijkingen in de buik palpabel maar hier zie ik daA oh nee: percussiel (lever niet vergroot)\... oh jế zou opgezet kunnen zijn bij die zuiplap, $($ milt niet vergroot .. niet), I vreemd dat er niet bij staat dat percussie pijnlijk is \... maar daar komt het
39. lever en milt niet vergroot lever opgezet

$H 1<-F$

$$
<- \text { (cond) zuiplap }
$$

hé een beetje vreemd wel, $\backslash$. (hij heeft een iets verhoogde ademhalingsfrekwentie) $\backslash$. (en buik ademt niet goed mee) $\backslash .$. dan vraag je je af terwijl een man normaal wel buikademhaling heeft wat er aan het handje is, $\backslash$ ik had eigenlijk verwacht dat die wel .. eh .. (défense musculair had) \. en dat daarom (de buik niet meeademde), ... en daarom dus die verhoogde... ademhalingsfrekwentie, I wel te verklaren waarom die matig is verhoogon

40. lichte drukpijn in epigastrio, geen defense musculair, verder niet drukpijnlijk, geen af palp.

lets verhoogde ademfrekwentie

$\&$ buik ademt niet goed mee

\& man normaal wel bukademhaling

$\rightarrow$ (cond) defense musculaire

$\rightarrow>$ (cond) buik niet meeademen

\& matig verhoogde ademfrekwentie

$\mathrm{FFF}->\mathrm{F} \rightarrow \mathrm{F} \rightarrow \mathrm{FF}$ 
41. (onderzock)

cor: percutoir niet vergroot; normale tonen; regulair ritme; geen geruisen (normale tonen, $\backslash$ regulair ritme) $).$. iemand die veel alcohol drinkt t... er zijn twee mogelijkheden of hij drinkt zwaar alcohol of sterke drank... dan lijkt me dat ie niet zo'n overmatig aan voch binnen krijgt, I maar als hij aan bier of wiin .. zich te pletter zuipt, dan krijgt hij natuurlijk een ontzettende vochthoeveelheid ... dat zou het hart. misschien wel moeiliik mee kunnen gaan, $\backslash$.. (hart niet vergroot, $\backslash$ normale tonen, $\backslash$ geen geruisen $)$

41. cor percutoir niet vergroot, normale tonen, regulair ritme , geen geruisen iemand die veel alcohol drinkt

$\rightarrow$ of [zwaar alcohol, sterke drank

$\rightarrow>$ krijgt niet zo'n overmaat aan vocht binnen]

$\rightarrow$ of [drinkt wijn of bier

$\rightarrow>$ krijgt ontzettend vocht hoeveelheid binnen

$\rightarrow$ (cau) zou hart misschien moeilijk mee kunnen krijgen]

<--(cond neg) hart niet vergroot, normale tonen $\mathrm{g}$

geruisen

$\mathrm{F} \rightarrow \mathrm{F} \rightarrow \mathrm{FHb7}]$

$\mathrm{F} \rightarrow[\mathrm{F} \rightarrow \mathrm{HbT} \rightarrow \mathrm{Hb} 7]<-\mathrm{F}$

42. (onderzoek)

pulm.: normaal beweeglijke grenzen beiderzijds; normaal ademgeruis
(.... normaal beweeglijke grenzen) $\backslash \ldots$ dan denk ik aan de achterkant .. toch waarvan die .. te weinig buikademhaling, buik betrokken is bij de ademhalingt

42. pulm normaal beweeglijke grenzen bdz, normaal ademgeruis $\mathrm{F} \rightarrow \mathrm{F}$ $\rightarrow$ ????????? to weinig buikademhaling

\section{3. (onderzoek)}

aa. femorales, palp.: pulseren beiderzijds goed

ausc.: geen abnormale vaatgeruisen

\section{(..... femorales) $\bigwedge \ldots . .$. ik vraag me af} waarom hij dat nou heeft gedaan.... zou kunnenh zijn dat hij denkt aan een aneurisma van de aorta .... die piin zou kunnen veroorzaken, $\backslash$... ik zou er zelf niet aan gedacht hebben om dat te doen, $\backslash$.. auscultatie van het abdomen wel maar niet van de arteria femoralest

\footnotetext{
43. aa femorales $\mathrm{gb}$

$\mathrm{F} \cdot[\mathrm{H} \cdot \mathrm{F}]$

$$
\underset{ }{\rightarrow} \rightarrow \text { (cond neg) [aneurisma van de aorta }
$$
}


44. (onderzoek)

rectaal toucher. geen afwijkingen

45. (onderzoek)

veneuze druk niet verhoogd had ik niet zo zeer afwijkingen

verwacht

... dat is iets waar wel aan gedacht moet worden, $\backslash$.. dan zit ik te denken aan .. de overvulling van de vaten als je dus bier of wiin drinkn .... of wat natuurlijk ook van sterke drank .. krijg je dorst van ... in hoge mate aan andere manieren vochtinname hebben!

45. veneuze druk niet verhoogd

[als verieuze druk verhoogd

<--(cau) [overvulling vaten $<-$ (cau) bier of wijn drinken]

$<-$ of (cau) [sterke drank

$\mathrm{F}<-[\mathrm{Hb} 7<--\mathrm{F}][\mathrm{F}->\mathrm{Hb}]]$ $\rightarrow$ (cau) dorst]

46. (onderzoek) parotis: beiderzijds niet opgezet

\section{7. (anammese)}

verder geen klachten

48. labgegevens:

serumamylase: $128 \mathrm{E}$ (normaal 8-16) glucose: $6.0 \mathrm{mmol} / \mathrm{l}$

(normaal 4.4-5.8)

leucocyten: $11.0 \times 10^{9} / 1$ (normaal 5-10 $\times 10^{9}$ )

BSE: $15 \mathrm{~mm}$ na $\mathbb{1}$ uur (normaal -10)
.. speekselklieren ... ((mompelen)) zou ik niet gedaan hebben, zou ik niet op gekomen zijn \... en dit lezende zie ik geen hint wat dat ermee te maken heeft

is verhoogd

dat is iets boven normaal glucose $\downarrow$. wat eet hij nou, $\backslash$ hij eet vet, $\backslash$ eh koolhydraten - zou wel kunnen dat het daaraan ligh .. alcohol . daar zil ook suikert. is ook suiker, of niet, dus dat lijkt me wel te verklaren

licht verhoogd, $\backslash$ nou hij kan dus een ontsteking hebben . (.. licht verhoogd leuco's) $\backslash$

(BSE dat is tot $10 \mathrm{~mm} \backslash$ normaal hij heeft $15 \mathrm{~mm}), \backslash$ ja ontsteking $\ . .$. zou ie inderdaad wel kunnen hebben als dat daarop wijst 
$\mathrm{Hb}: 9.0 \mathrm{mmol} / \mathrm{l}$

(normaal 8.8-11.2)

$\mathrm{Hb}$ is normaal i maar ligt wel bij de ondergreens, I nou met zijn voedingspatroon verwondert me dat nied

.. ik zou het $\mathrm{Ht}$ willen weten $\mathrm{V}$. want als iemand veel.. drinkt, $\backslash$ veel yochtinname heeft \. een verdunningsfaktor van het bloed en daardoor een versnelde BSE, \dus die $\mathrm{Ht}$ zou ik zeker willen weten, $\backslash$.... dat was het

48. serumamylase $128 \mathrm{E}$

\& normaal 8-16E

$F F \rightarrow t$

$\rightarrow$ verhoogd

glucose $6 \mathrm{mmol} / \mathrm{l}$

$F \rightarrow t$

$\rightarrow$ iets boven normaal

vet eten en koolhydraten

$\rightarrow$ (cau) verhoogd glucose

<- (cau) [alcohol

$F F \rightarrow F<-[F \rightarrow F]$ $\rightarrow \rightarrow$ (iden) suiker?]

leucocyten 11

$\rightarrow-$ licht verhoogd

$\mathrm{F}-\rightarrow \mathrm{t}-\rightarrow \mathrm{H} 7$

$\rightarrow$ ontsteking

BSE normaal -10

\& BSE 15

$\mathrm{FF} \rightarrow>\mathrm{H} 7$

- >ontsteking

$\mathrm{Hb}$

$\rightarrow>$ normaal, maar wel bij ondergrens

$F \rightarrow t t<-F$ $<-$ (cau) voedingspatroon

veel vocht inname

$\rightarrow$ (iden) verdunningsfaktor van het bloed

$\rightarrow$ (cau) versnalde BSE

$\rightarrow$ (cau) ........ Ht

DD

pancreatitis, chronisch of acuut maag- of duodenumulcus

leverproblematiek (iets minder waarschijnlijk) 


\section{BIJLAGE 5}

\section{HYPOTHESENETWERKEN}

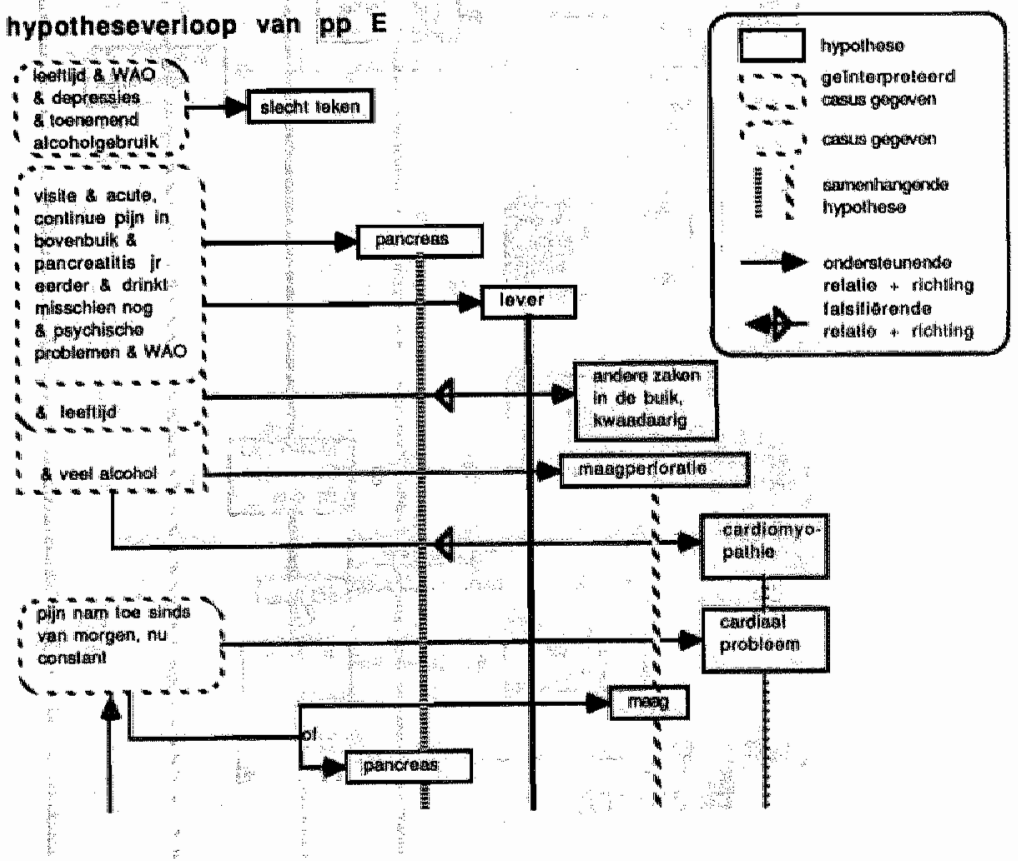




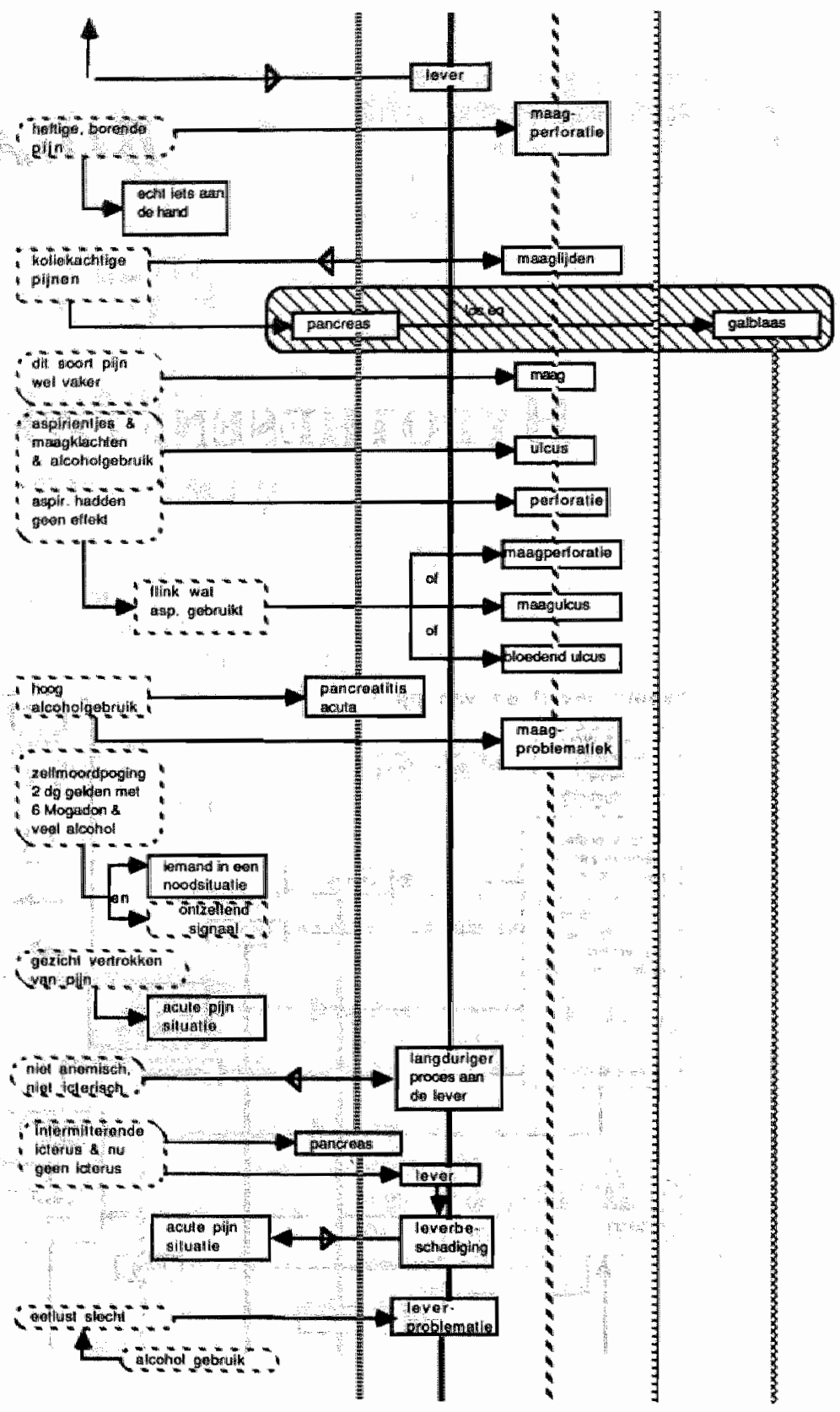




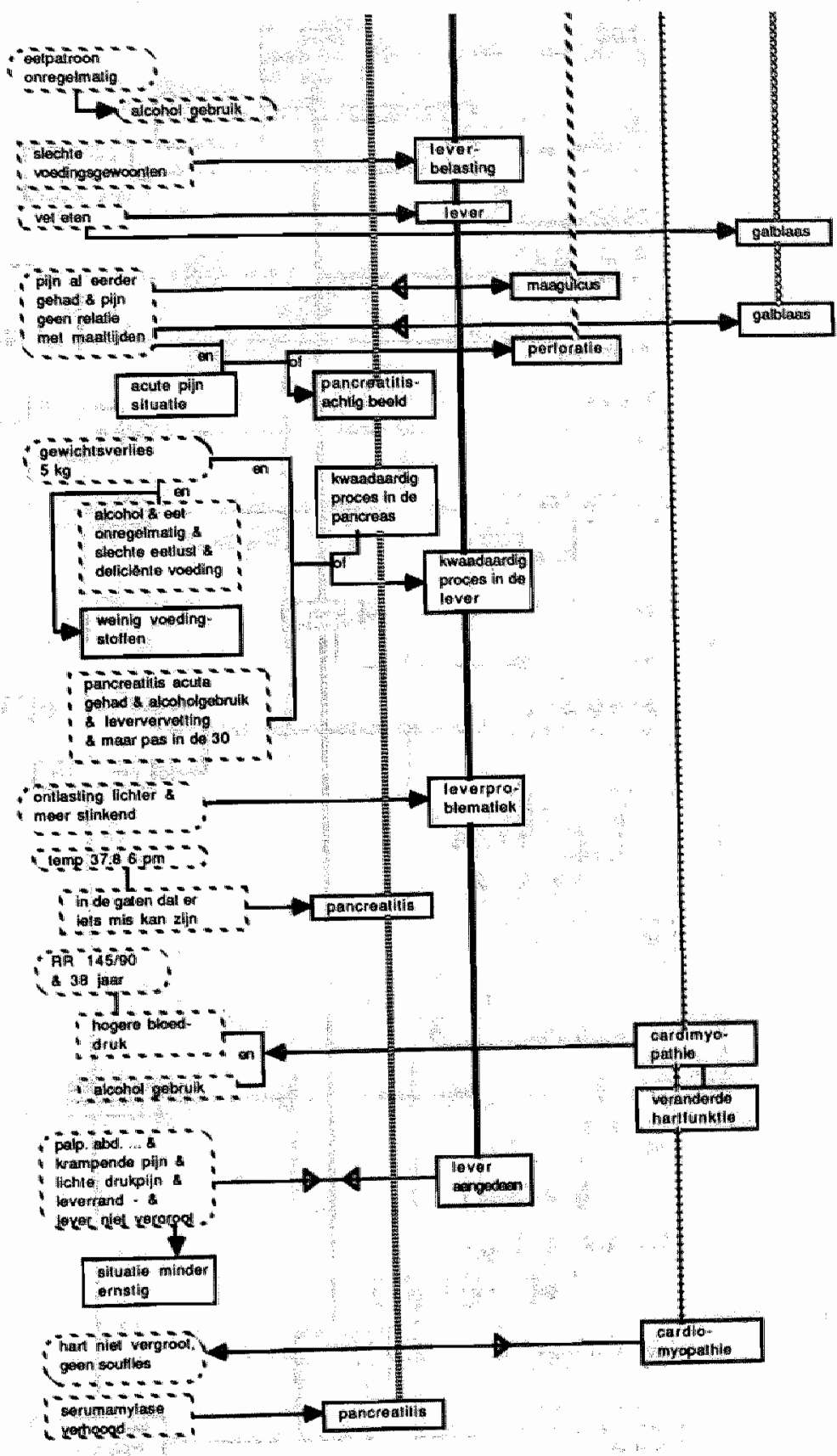




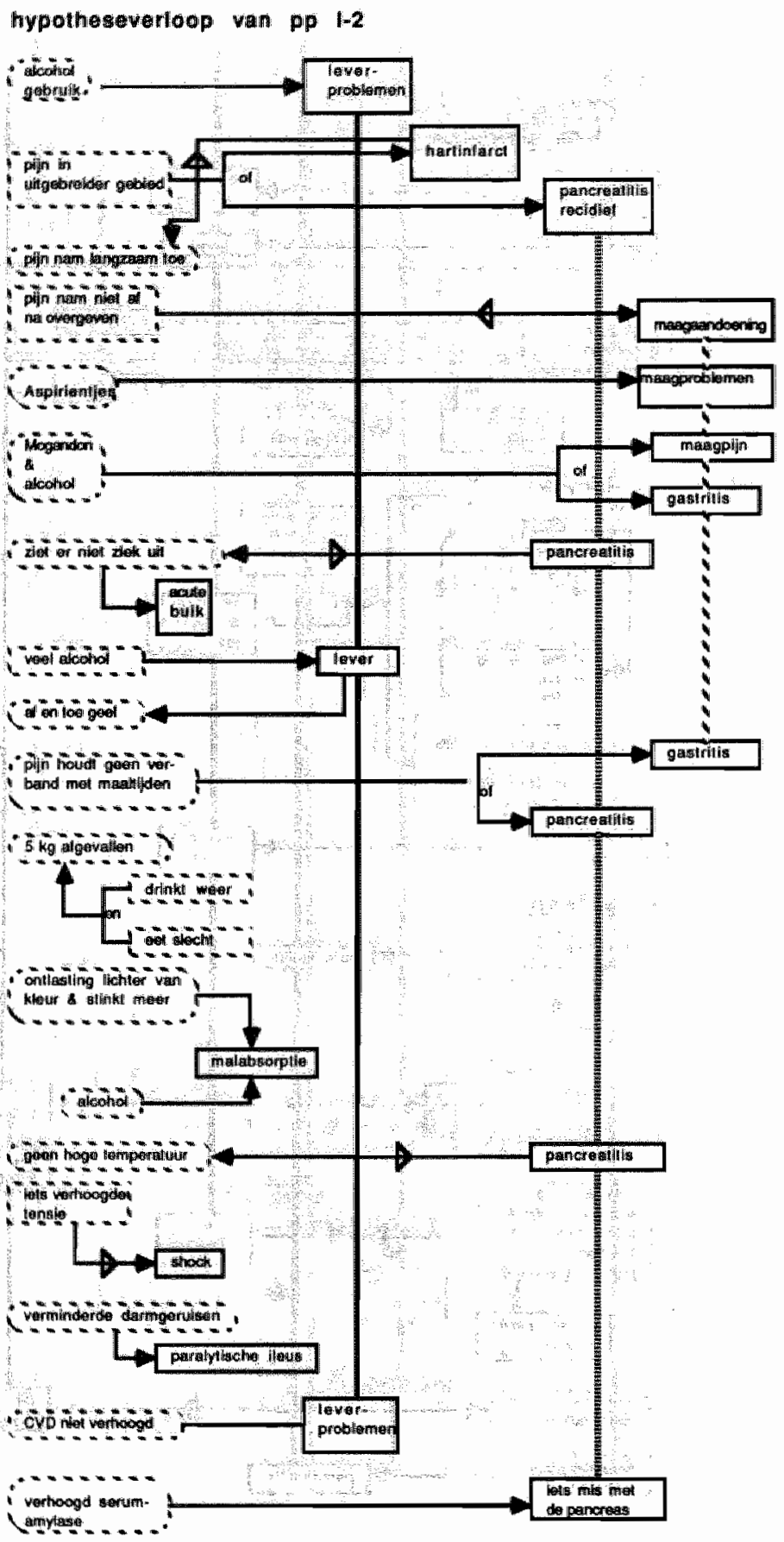


hypotheseverloop van pp $1-1$

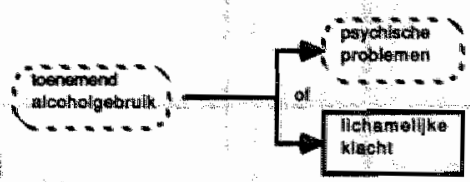

$\therefore$ incinar gotedon

i pancroalih ache
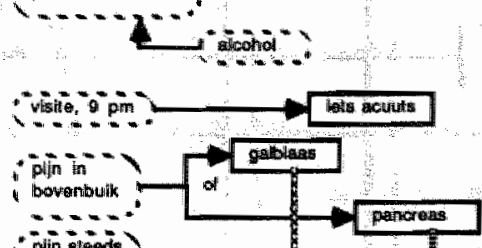

"ilin silonds

1 toegenomina"

1 mill Constant?

$-1==$

4

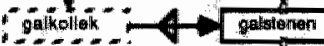

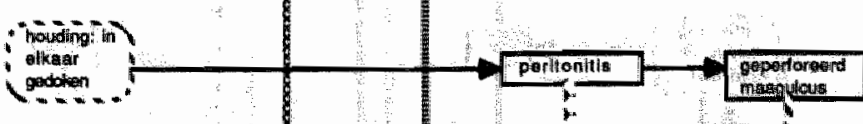

- overgeven

1 had gaen

- inuloed op

ife piln

-

op pifre edr

jear gatedent

$-=$

pilin valker

$-m=$

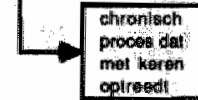

- Difrir

- streads vanzo"

- bhrien cant day

mel ikere

ariradest

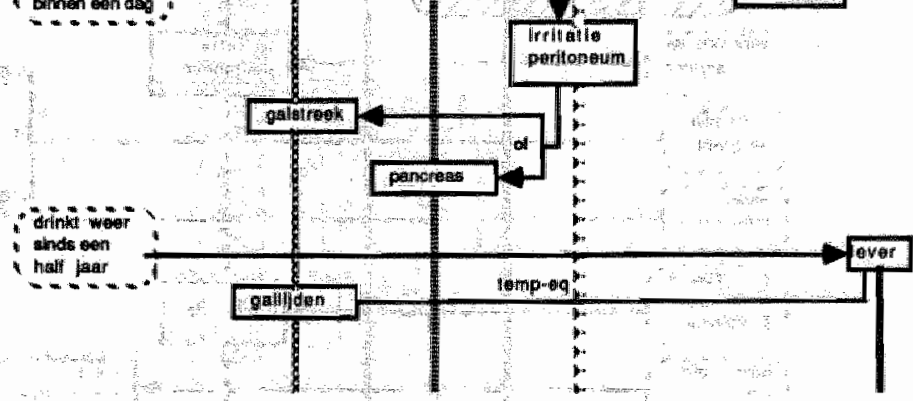




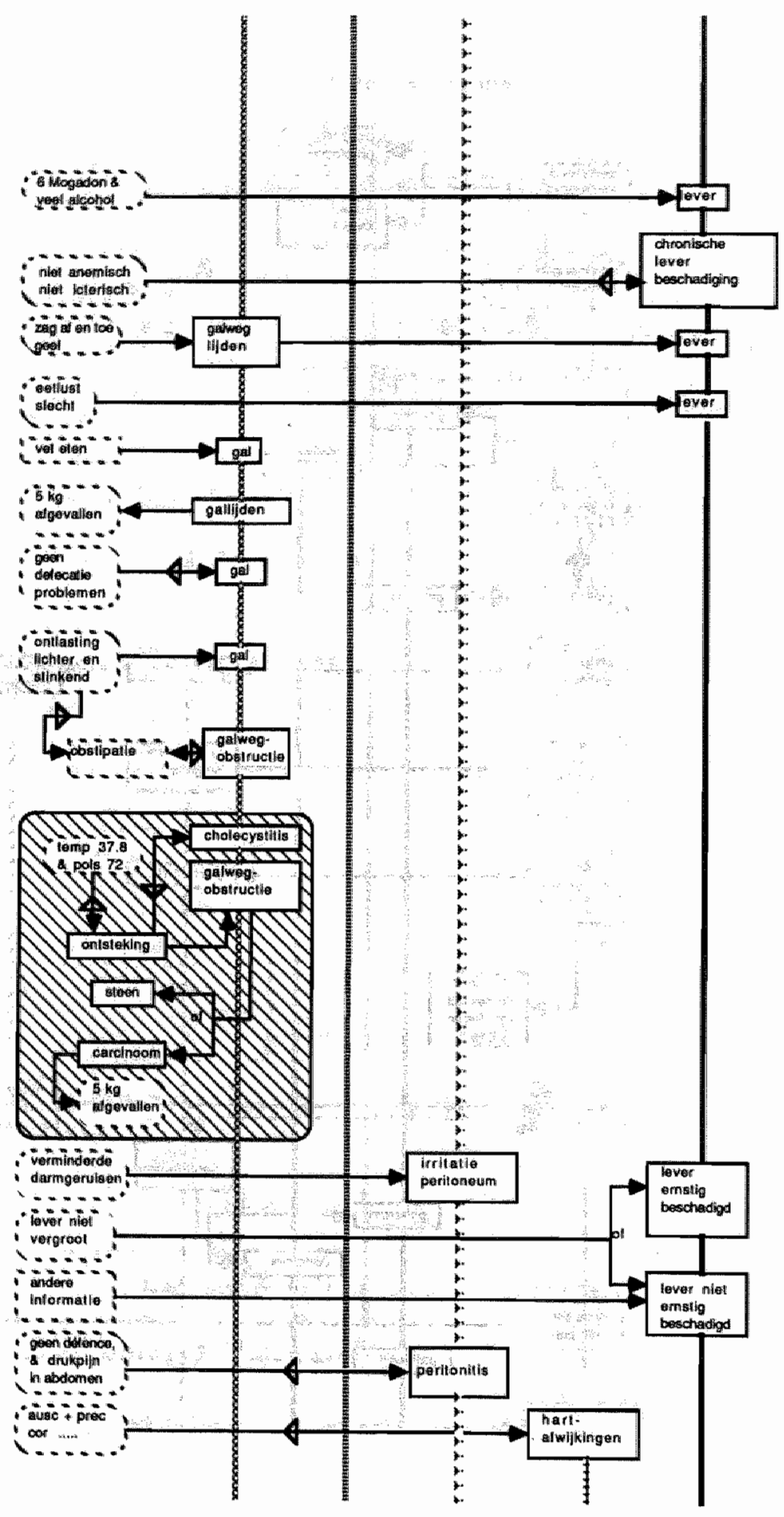




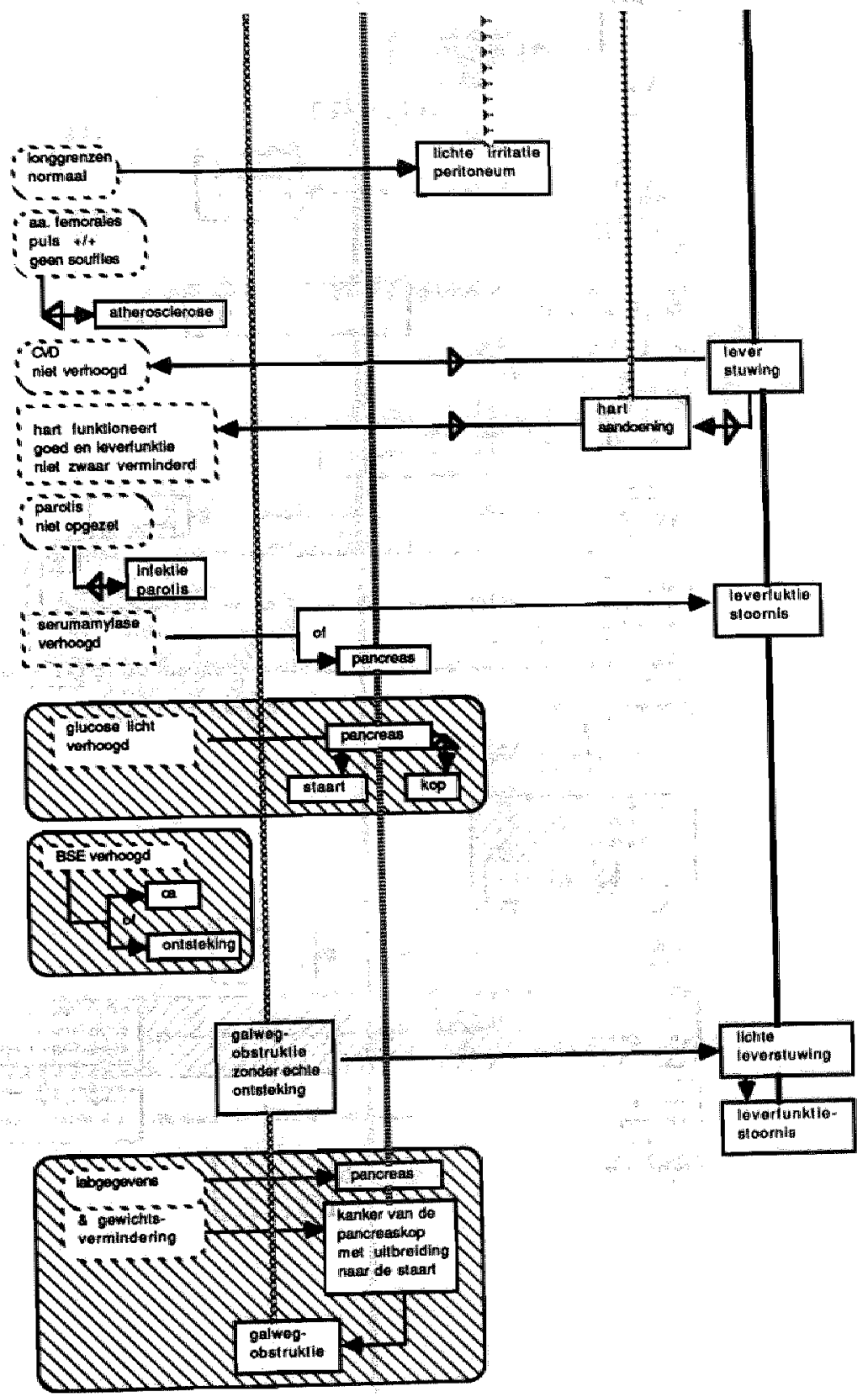




\section{hypotheseverloop van pp N}

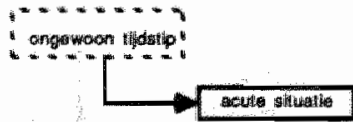

(p)

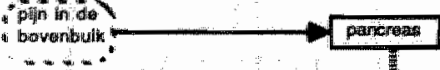

1. kiar nat

1 the renger

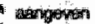

wat do pan

bot hevight is

$x-5=-2=$

- pinn link op

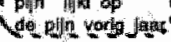

- indir domation

1 valiker dill soont pifin gohod,

$\checkmark$ drintilat war

$\ldots=-m=-\ldots=\ldots$

relatie fuisis an

atcohol en pancreatitis

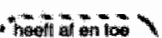

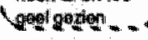

vot ation

$\forall-\infty=$

- aloonor

Q vet whot

8 peych lischer problement

iongazond atan

$-=-2=-2=-$

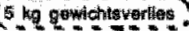

$-7$

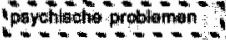
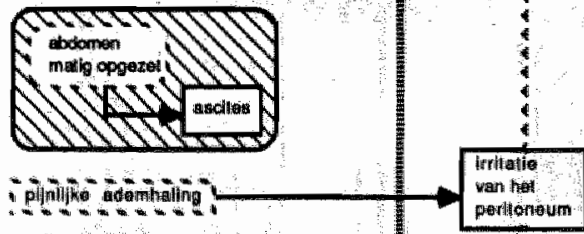

Bover

asidoening

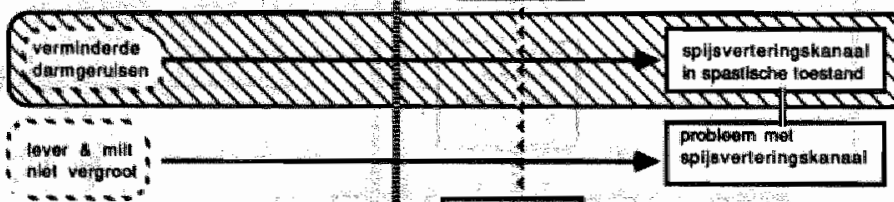

preandoteneso

hen andisto

pritkikelling 


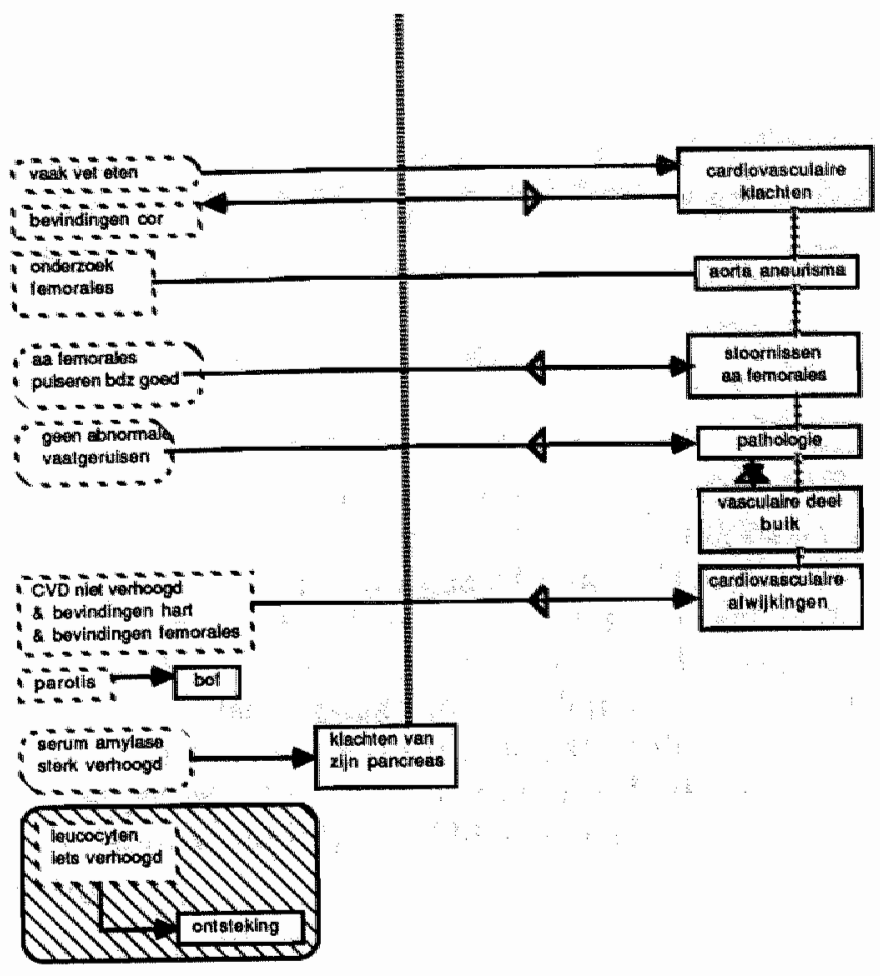




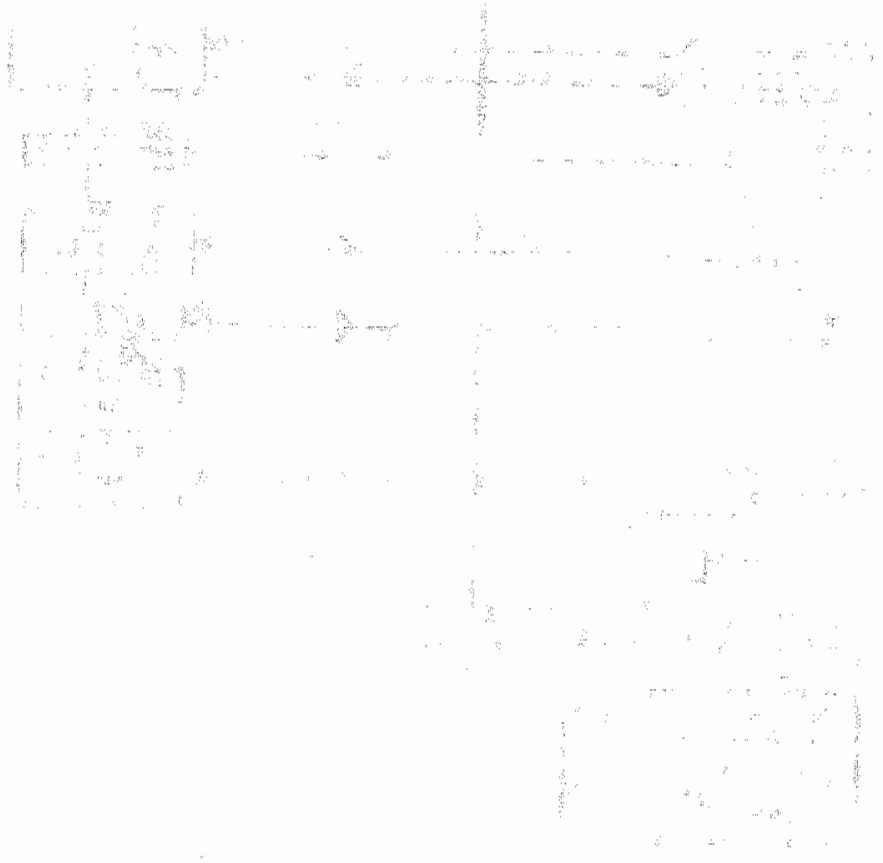




\section{CURRICULUM VITAE}

Henny Petronella Adriana Boshuizen werd op 23 januari 1950 geboren te Weesp. Van 1962 tot 1968 volgde zij middelbaar onderwijs. Drie jaar daarvan werden doorgebracht aan de Christelijke MULO te Weesp; de volgende drie jaar bezocht zij de Christelijke Hogereburgerschool te Amsterdam. In 1968 werd het HBS-b diploma behaald. Daarna ging zij aan de Universiteit van Amsterdam psychologie studeren. In 1979 behaalde zij het doctoraal diploma met als specialisatie de psychologische funktieleer. Sindsdien was zij, afgezien van een korte onderbreking, werkzaam bij de vakgroep Onderwijsontwikkeling en Onderwijsresearch van de Rijksuniversiteit Limburg. 